\author{
RECENYED \\ SFP 0 y 1974 \\ Y/TS-806/R3 \\ OS TI \\ RESOURCE CONSERVATION AND \\ RECOVERY ACT (RCRA) \\ PART B PERMIT APPLICATION \\ FOR CONTAINER STORAGE UNITS \\ AT THE OAK RIDGE Y-12 PLANT
}

Building 9201-4 Container Storage Area

Building 9720-9 Storage Unit

Classified Container Storage Unit, Building 9720-25

RCRA and Mixed Waste Storage and Staging,

Building 9720-31

RCRA and PCB Container Storage Area, Building 9720-58

Building 9811-1 RCRA Container Storage Unit (OD-8)

Containerized Waste Storage Area (CWSA)

Environmental Management Department

Health, Safety, Environment, and Accountability Organization

August 1994

Prepared by the

Oak Ridge Y-12 Plant

Oak Ridge, Tennessee 37831

Managed by

MARTIN MARIETTA ENERGY SYSTEMS, INC.

for the

U.S. DEPARTMENT OF ENERGY

under contract DE-AC05-84OR2 21400 


\section{DISCLAIMER}

This report was prepared as an account of work sponsored by an agency of the United States Government Neither the United States Government nor any agency thereof, nor any of their employees, makes any warranty, express or implied, or assumes any legal liability or responsibility for the accuracy, completeness, or use fulness of any information, apparatus, product, or process disclosed, or represents that its use would not infringe privately owned rights. Reference herein to any specific commercial product, process, or service by trade name, trademark, manu facturer, or otherwise, does not necessarily constitute or imply its endorsement, recommendation, or favoring by the United States Government or any agency thereof. The views and opınions of authors expressed herein do not necessarily state or reflect those of the United States Government or any agency thereof. 


\section{DISCLAIMER}

This report was prepared as an account of work sponsored by an agency of the United States Government. Neither the United States Government nor any agency Thereof, nor any of their employees, makes any warranty, express or implied, or assumes any legal liability or responsibility for the accuracy, completeness, or usefulness of any information, apparatus, product, or process disclosed, or represents that its use would not infringe privately owned rights. Reference herein to any specific commercial product, process, or service by trade name, trademark, manufacturer, or otherwise does not necessarily constitute or imply its endorsement, recommendation, or favoring by the United States Government or any agency thereof. The views and opinions of authors expressed herein do not necessarily state or reflect those of the United States Government or any agency thereof. 


\section{DISCLAIMER}

Portions of this document may be illegible in electronic image products. Images are produced from the best available original document. 


\title{
RESOURCE CONSERVATION AND RECOVERY ACT (RCRA) PART B PERMIT APPLICATION FOR CONTAINER STORAGE UNITS AT THE OAK RIDGE Y-12 PLANT
}

\author{
Building 9201-4 Container Storage Area \\ Building 9720-9 Storage Unit \\ Classified Container Storage Unit, Building 9720-25 \\ RCRA and Mixed Waste Storage and Staging, Building 9720-31 \\ RCRA and PCB Container Storage Area, Building 9720-58 \\ Building 9811-1 RCRA Container Storage Unit (OD-8) \\ Containerized Waste Storage Area (CWSA)
}

Environmental Management Department

Health, Safety, Environment, and Accountability Organization

Prepared by the

Oak Ridge Y-12 Plant

Oak Ridge, Tennessee 37831

Managed by

MARTIN MARIETTA ENERGY SYSTEMS, INC.

for the

U.S. DEPARTMENT OF ENERGY

under contract DE-AC05-84OK21400 


\section{TABLE OF CONTENTS}

Page No.

SECTION B - FACILITY DESCRIPTION . . . . . . . . . . . B-1

B-1 General Description $\ldots \ldots \ldots \ldots \ldots \ldots \ldots \ldots \ldots \ldots \ldots$ B-1

B-2 Topographic Map $\ldots \ldots \ldots \ldots \ldots \ldots \ldots \ldots \ldots \ldots \ldots \ldots \ldots \ldots \ldots$

B-3 Location Information $\ldots \ldots \ldots \ldots \ldots \ldots \ldots \ldots \ldots \ldots \ldots \ldots \ldots$

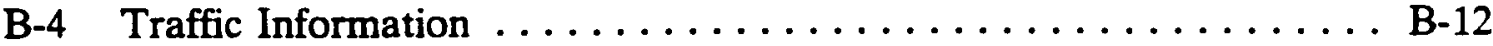

SECTION C - WASTE CHARACTERISTICS $\ldots \ldots \ldots \ldots \ldots \ldots \ldots \ldots$ C-1

C-1 Chemical and Physical Analyses . . . . . . . . . . . . .

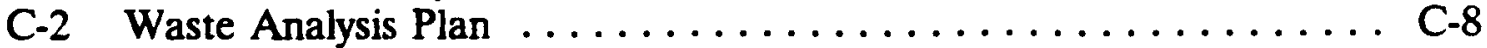

C-3 Land Disposal Restrictions $\ldots \ldots \ldots \ldots \ldots \ldots \ldots \ldots \ldots \ldots \ldots \ldots \ldots \ldots$

SECTION D - PROCESS INFORMATION $\ldots \ldots \ldots \ldots \ldots \ldots \ldots \ldots \ldots$ D-1

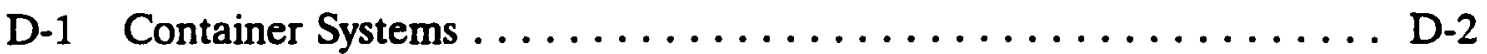

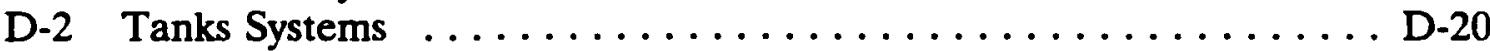

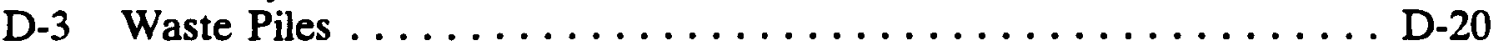

SECTION E - GROUNDWATER MONITORING $\ldots \ldots \ldots \ldots \ldots \ldots \ldots$ E-1

SECTION F - PROCEDURES TO PREVENT HAZARDS $\ldots \ldots \ldots \ldots \ldots$ F-1

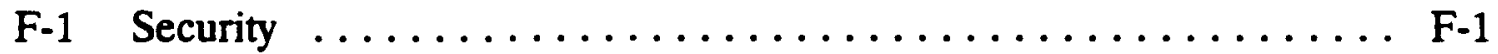

F-2 Inspection Schedule $\ldots \ldots \ldots \ldots \ldots \ldots \ldots \ldots \ldots \ldots \ldots$ F-4

F-3 Waiver of Preparedness and Prevention Requirements .......... F-7

F-4 Preventative Procedures, Structures and Equipment . . . . . . . . F-8

F-5 Prevention of Reaction of Ignitable, Reactive, and Incompatible Wastes .................... F-10

SECTION G - CONTINGENCY PLAN $\ldots \ldots \ldots \ldots \ldots \ldots \ldots \ldots \ldots \ldots$

General Facility Description $\ldots \ldots \ldots \ldots \ldots \ldots \ldots \ldots \ldots \ldots$

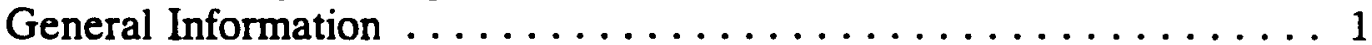

Emergency Coordinators . .................... 2

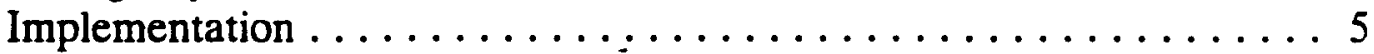

Control Procedures--Incident Commander .............. 5

Emergency Response Procedures--Emergency Coordinator . . . . . . 6

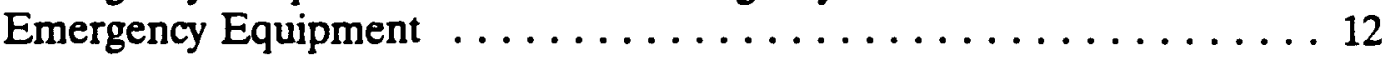

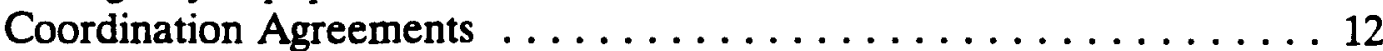

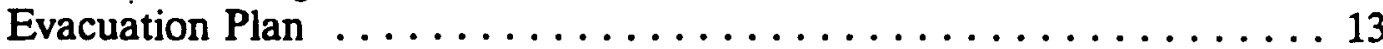

Required Reports ....................... 13 
TABLE OF CONTENTS

(Continued)

Page No.

SECTION H - PERSONNEL TRAINING $\ldots \ldots \ldots \ldots \ldots \ldots \ldots \ldots \ldots$ H-1

H-1 Outline of Training Program $\ldots \ldots \ldots \ldots \ldots \ldots \ldots \ldots \ldots . . . . .1$

H-2 Implementation and Documentation of Training Program $\ldots \ldots \ldots$ H-7

SECTION I - CLOSURE PLAN, POST CLOSURE PLAN, AND FINANCIAL REQUIREMENTS $\ldots \ldots \ldots \ldots \ldots \ldots \ldots$ I-1

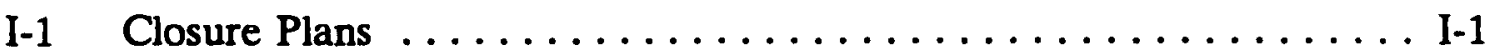

I-2 Post-Closure Plan .......................

I-3 Certifications and Notices Required For Closure . . . . . . . . . I-13

I-4 Closure Cost Estimate . . . . . . . . . . . . . . . . . I-14

I-5 Financial Assurance Mechanism For Closure . . . . . . . . . . I-14

I-6 Post-Closure Cost Estimate . . . . . . . . . . . . . . . I-14

I-7 Financial Assurance Mechanism For Post-Closure . . . . . . . . . I-14

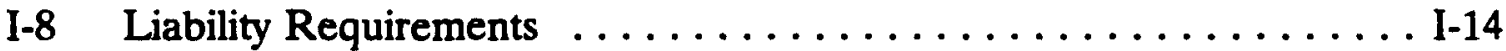

I-9 State Financial Mechanisms $\ldots \ldots \ldots \ldots \ldots \ldots \ldots \ldots \ldots \ldots \ldots \ldots \ldots \ldots \ldots \ldots .14$

SECTION J - RECORDKEEPING $\ldots \ldots \ldots \ldots \ldots \ldots \ldots \ldots \ldots \ldots \ldots \ldots \ldots \ldots$ J-1

J-1 Manifest Requirements $\ldots \ldots \ldots \ldots \ldots \ldots \ldots \ldots \ldots \ldots . . . . .1$

$\mathrm{J}-2$ Operating Records $\ldots \ldots \ldots \ldots \ldots \ldots \ldots \ldots \ldots \ldots \ldots \ldots \ldots$

SECTION K - OTHER FEDERAL LAWS $\ldots \ldots \ldots \ldots \ldots \ldots \ldots \ldots \ldots$ K-1

SECTION L - ORGANIC AIR EMISSIONS $\ldots \ldots \ldots \ldots \ldots \ldots \ldots \ldots$ L-1

SECTION M - SOLID WASTE MANAGEMENT UNITS $\ldots \ldots \ldots \ldots \ldots$ M-1

SECTION N - CERTIFICATION $\ldots \ldots \ldots \ldots \ldots \ldots \ldots \ldots \ldots \ldots \ldots \ldots \ldots \ldots \ldots \ldots$ 


\section{LIST OF FIGURES}

Figure No.

Page No.

B-1 Wind Rose from the West Meteorological Tower at 60 meters at the Y-12 Plant

B-2 Wind Rose from the East Meteorological Tower at 100 meters at the Y-12 Plant $\ldots \ldots \ldots \ldots \ldots \ldots \ldots \ldots \ldots \ldots$ B-11

D-1 Building 9201-4 Container Storage Layout ................ D-4

D-2 Building $9720-9$ Container Storage Layout $\ldots \ldots \ldots \ldots \ldots \ldots \ldots \ldots$ D-5

D-3 Building $9720-25$ Container Storage Layout $\ldots \ldots \ldots \ldots \ldots \ldots \ldots \ldots$ D-7

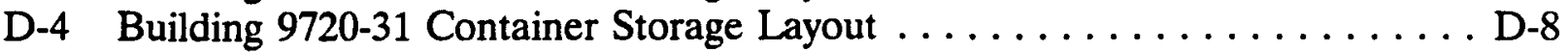

D-5 Building $9720-58$ Container Storage Layout $\ldots \ldots \ldots \ldots \ldots \ldots \ldots \ldots$ D-9

D-6 Building 9811-1 (OD-8) Container Storage Layout . . . . . . . . . . . D-11

D-7 Containerized Waste Storage Area Layout $\ldots \ldots \ldots \ldots \ldots \ldots \ldots \ldots$ D-12

I-1 Schedule of Closure for Building $9201-4 \ldots \ldots \ldots \ldots \ldots \ldots \ldots \ldots$ I-3

I-2 Schedule of Closure for Building $9720-9 \ldots \ldots \ldots \ldots \ldots \ldots \ldots \ldots$ I-4

I-3 Schedule of Closure for Building $9720-25 \ldots \ldots \ldots \ldots \ldots \ldots \ldots \ldots$ I-5

I-4 Schedule of Closure for Building $9720-31 \ldots \ldots \ldots \ldots \ldots \ldots \ldots$ I-6

I-5 Schedule of Closure for Building 9720-58 $\ldots \ldots \ldots \ldots \ldots \ldots \ldots$ I-7

I-6 Schedule of Closure for OD-8 $\ldots \ldots \ldots \ldots \ldots \ldots \ldots \ldots \ldots \ldots$ I-8

I-7 Schedule of Closure for CWSA $\ldots \ldots \ldots \ldots \ldots \ldots \ldots \ldots \ldots \ldots$ I-9 


\section{LIST OF TABLES}

Table No.

Page No.

C-1 Typical Types of RCRA Wastes Stored . . . . . . . . . . . . C-5

C-2 Waste Analysis Parameter and Rationale $\ldots \ldots \ldots \ldots \ldots \ldots \ldots$ C-10

C-3 Test Methods for Containerized Waste ................. C-11

C-4 Sampling Equipment for Particular Waste Types $\ldots \ldots \ldots \ldots \ldots \ldots$ C-13

D-1 Container Storage Area Capacities and Secondary Containment Capacities ................... D-15

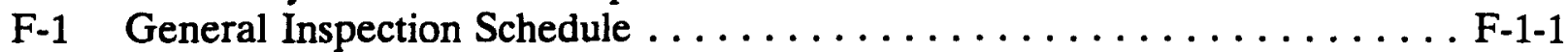

F-2 Container Storage Area Inspection Schedule $\ldots \ldots \ldots \ldots \ldots \ldots \ldots \ldots$ F-1-2

F-3 Daily Inspection Log Sheet for Container Storage Areas . . . . . . . . . F-2-1

F-4 Weekly Inspection Log Sheet for Container Storage Areas . . . . . . . . F F-2-2 


\title{
LIST OF APPENDICES
}

\author{
B-1 Maps \\ B-2 Wind Roses \\ C-1 Typical Waste Analysis Data \\ C-2 Waste Identification Forms \\ C-3 Examples of Potentially Incompatible Waste \\ D-2 Secondary Containment Calculations \\ F-1 General Inspection Schedule \\ F-2 Inspection Logs \\ H-2 Job Descriptions \\ H-3 Training Requirements
}




\section{LIST OF ACRONYMS}

BTU

British Thermal Unit

CFR

Code of Federal Regulations

CWSA

Containerized Waste Storage Area

DARA

Disposal Area Remedial Action

DOE

U.S. Department of Energy

EOC

Emergency Operations Center

EPA

U.S. Environmental Protection Agency

HP

Health Physics

HSWA

Hazardous and Solid Waste Amendments

IH

Industrial Hygiene

IRWTA

Interim Reactive Waste Treatment Area

MMES

Martin Marietta Energy Systems, Inc.

$\mathrm{NaK}$

sodium potassium

OJT

On-The-Job Training

ORNL

Oak Ridge National Laboratory

OSHA

Occupational Safety and Health Act

PED

Plant Emergency Director

PCB

polychlorinated biphenyl

PSS

Plant Shift Superintendent

RCRA

Resource Conservation and Recovery Act

SARA

Superfund Amendments Reauthorization Act

SID

Stream Identification

TCLP

Toxicity Characteristic Leaching Procedure

TDEC

Tennessee Department of Environment and Conservation

TMS

Training Management System

TSCA

Toxic Substances Control Act

TSD

Treatment, Storage, and Disposal

UCN

Uniform Control Number

UL Underwriters Laboratory

WSSO

Waste Storage and Shipping Operations 


\section{SECTION B \\ FACILITY DESCRIPTION}

This section of the application provides a general description of the hazardous waste management facility as required by 40 CFR Part 270.14(b)(1) and Rules Governing Hazardous Waste Management in Tennessee, Rule 1200-1-11-.07(5)(a). This description is intended to provide guidance and facility orientation to the permit application reviewer and the permit writer for the Oak Ridge Y-12 Plant.

\section{B-1 GENERAL DESCRIPTION}

The Oak Ridge Y-12 Plant was built by the U.S. Army Corps of Engineers in 1943 as part of the Manhattan Project and was given the original mission to separate the fissionable isotope of uranium by the electromagnetic process. After World War II, the electromagnetic separation process was discontinued in favor of the more economical gaseous diffusion process. In recent years, the Y-12 Plant staff has developed this facility into a highly sophisticated manufacturing and developmental engineering organization.

The U.S. Department of Energy (DOE) owns and operates the Y-12 Plant. Personnel from Martin Marietta Energy Systems, Inc., (Energy Systems) co-operate and manage the Y-12 Plant. Since 1984, the facility has been managed by Energy Systems personnel, under a prime contract with DOE. The contract is administered by personnel at DOE Oak Ridge Operations Office.

The Y-12 Plant occupies approximately 800 acres in Anderson County, Tennessee, and is located southwest of the City of Oak Ridge. The site employs approximately 4,000 people including employees of the Oak Ridge National Laboratory assigned to the Y-12 Plant. Two surface streams, East Fork Poplar Creek and Bear Creek, border the facility on the south, east, and southwest sides of the plant. There is access to the Y-12 Plant, controlled on Bear Creek Road on the north side of the facility; indirect access from Scarboro Road on the east side of the facility; and indirect access to the facility on the south side via Bethel Valley Road. A controlled access road from Bethel Valley Road by way of Mt. Vernon Road is located on the southwest side of the site.

It is the mission of the Y-12 Plant to serve as a key manufacturing technology center for the development and demonstration of unique materials, components, and services of importance to DOE and the nation. This is accomplished through the reclamation and 
storage of nuclear materials, manufacture of nuclear materials, manufacture of components for the defense capabilities of the nation, support to national security programs, and services provided to other customers as approved by DOE.

There are seven container storage areas covered by this application. These container storage areas can be located on Map 2 in Appendix B-1. The seven facilities included in this application are as follows:

1. Building 9201-4 Container Storage Area

2. Building 9720-9 Storage Unit

3. Classified Container Storage Unit, Building 9720-25

4. RCRA and Mixed Waste Storage and Staging, Building 9720-31

5. RCRA and PCB Container Storage Area, Building 9720-58

6. Building 9811-1 RCRA Container Storage Unit (OD-8)

7. Containerized Waste Storage Area (CWSA).

\section{Building 9201-4 Container Storage Area}

Building 9201-4 Container Storage Area is located in the former southeast switch gear room on the ground floor of Building 9201-4 (Alpha Four). This unit is located within the exclusion area of the Y-12 Plant and is used to store mercury-contaminated solids such as soil or insulation in containers. The solids may also be defined as mixed waste. The total proposed permitted capacity of material to be stored in containers at $9201-4$ is 17,160 gallons.

\section{Building 9720-9 Storage Unit}

Building 9720-9 is a warehouse storage unit located on Third Street, southeast of the Steam Plant, and approximately 500 yards west of Portal 28.

Building 9720-9 is a storage unit for hazardous, nonhazardous, and mixed waste. Waste is stored at this unit until waste analysis and appropriate disposal (bulk storage and/or off-site shipment) can be arranged. All classes of RCRA wastes, except for "K" wastes, hazardous wastes from specific sources (40 CFR Part 261.32 and Tennessee Rule 1200-1-11.02(4)) are stored in this unit.

Building $9720-9$ is approximately $240 \times 50$ feet. It is equipped at each end (west and east) with a personnel door, a vehicle access roll-up door, and a ramp. The front (south side) 
contains two personnel doors with one leading into the west end, and one leading into the east end. Inside the building, separating the west and east end, is a floor to roof wall containing a personnel door, a roll-up door, and a ramp. The building has a concrete floor coated with a chemical resistant sealing compound to ensure containment of any leaks.

Building $9720-9$ is divided into two sections: a west end and an east end.

\section{WEST END}

The west end stores hazardous and mixed wastes, some of which are PCBcontaminated. It has been subdivided into a storage room for flammable materials, aisle space, and five storage areas for segregation of incompatible RCRA hazardous waste divided by two-inch, roll-over dikes. The two-inch, roll-over dike makes possible the movement of containers over the dikes by using a forklift. These dikes provide emergency containment in the event of a spill. The capacity of the west end is 195,000 gallons.

\section{EAST END}

Currently, the east end is undergoing modification to the floor and dike; therefore it is not receiving or storing any hazardous or mixed waste. Storage of waste will resume once the modification is complete. The capacity of the east end is 198,440 gallons.

\section{Classified Container Storage Unit, Building 9720-25}

The Classified Container Storage Unit is located on M Road between West 2nd and 3rd streets in Building 9720-25.

The Building 9720-25 is a storage unit designed for storage of classified wastes generated at the Y-12 Plant. The wastes include materials, fabricated parts, and containers which have been security classified to prevent dissemination of potentially vital information. Storage in one part of this unit of classified waste, contaminated with hazardous constituents, is necessary due to present uncertainties as to final modes of treatment and/or disposal of classified and/or hazardous wastes. The stored materials include hazardous, nonhazardous, and mixed wastes. Wastes at this unit are accepted in 55-gallon drums meeting Department of Transportation (DOT)-specification, B-25 boxes, and other specially constructed containers. 
Building 9720-25 is a metal and concrete block building with a concrete floor. The I hazardous waste storage area floor is waterproof, fire resistant, and has an impervious coating. Building $9720-25$ is approximately $84 \times 200$ feet. There are personnel and roll-up doors on the north, south, and west sides.

Building $9720-25$ is a storage area for classified hazardous, nonhazardous, and mixed wastes, and is divided into two sections:

1) The northwest corner diked area is a storage area for RCRA hazardous wastes. The diked area is constructed with concrete curbing. The RCRA storage area measures $39.9 \times 27.9$ feet. It has a maximum storage capacity of 32,465 gallons. I

2) The northeast corner of the west end and the whole southwest end is a storage area for classified nonhazardous and radioactive wastes.

RCRA and Mixed Waste Storage and Staging, Building 9720-31

RCRA and Mixed Waste Storage and Staging, Building 9720-31, is known as the "RCRA Motel" and is used to store solids, liquids, and sludge wastes. Building 9720-31 is located on the south side of West Third Street, east of the existing Fire Training Facility, Building 9817.

Building 9720-31 is a one story structure, constructed of light weight concrete block masonry walls and partitions. It has a pre-cast concrete roof deck and an impervious concrete floor slab. The building has a covered loading dock on the north side with a paved access and truck maneuvering area. A portable scale for weighing containers to be transported off-site is also located at the unit.

The building is partitioned into 15 rooms: one supply room, seven staging rooms, and seven storage rooms. The supply room contains protective clothing, protective equipment, communications equipment, and spill kits. Rooms 1 through 7 are the designated storage rooms. Rooms 8 through 14 are the designated staging rooms, with steel shelves on their east and west walls, to accommodate various size waste containers. Normally, the largest containers in any of the staging or storage rooms are 55-gallon drums, however, 85-gallon overpack containers may be used to store waste. Waste stored in the staging and storage rooms may be in DOT-specification containers or in the original product containers. The total capacity for all fourteen storage rooms is 46,000 gallons. 
Each staging and storage room has two doors. The door in the north wall is the main entrance, and the door in the south wall is an emergency exit. All staging and storage rooms have floors which slope to the center of the room, where a blind sump is located to collect any waste which may spill. All rooms except the supply room are accessed by concrete ramps to aid in handling the waste with hand trucks and fork lifts. There are safety showers and eyewash stations in rooms $1,4,6,8,9,10,11,12$, and 14 . All storage and staging rooms, with the exception of rooms 3 and 13, have fire extinguishing sprinkler systems located on the ceiling. Rooms 3 and 13 have no sprinkler system, safety shower, or eyewash station since they are designated as the storage area for water-reactive chemicals. In addition, safety shower/eyewash stations are located outside rooms 4 and 11.

All rooms have ventilation systems which can be activated manually or automatically. This allows for proper ventilation at all times to ensure employee comfort and to prevent the accumulation of hazardous vapors which may result from normal operation, or from accidental spills or leaks.

Rooms 2 through 13 have heaters. Rooms 1 and 14 are designed to store flammable liquids and combustibles so heat is delivered through vents from other rooms. Rooms 1 and 14, located on the outer ends of the building, are equipped with blow-out panels in the exterior walls to release explosive forces. Explosive proof electrical equipment is provided for the two rooms.

\section{RCRA and PCB Container Storage Area, Building 9720-58}

Building 9720-58 is a warehouse storage unit located on the north side of Old Bear Creek Road about a quarter mile west of the Y-12 Plant. The unit is in close proximity to OD-9 and south of the Y-12 West End Treatment Facility.

Building 9720-58 is utilized as a storage and staging area for PCB-contaminated equipment (e.g., transformer, capacitors, and electrical switch gear). The unit is also used to store hazardous waste and will be used as staging area for other wastes awaiting off-site shipment. Waste is consolidated at this unit until waste analysis and appropriate disposal arrangements can be initiated.

Waste containers received at Building 9720-58 include 30- and 55-gallon drums, 330-and 600gallon portable polytanks, 96 cubic feet B-25 Boxes, and PCB-contaminated equipment. Polytanks are actually portable containers consisting of either a 330 - or 600 -gallon 
rectangular shaped polyethylene vessel surrounded by a metal reinforced caged frame. The steel frame has a built in pallet bottom to enable movement by forklift truck.

The unit structure consists of a metal roof with temporary plastic sides over a 98- by 39-foot concrete pad. The concrete pad is coated with a chemically resistant epoxy and surrounded by a 6-inch curb. The pad is gently sloped from the center to the north and south sides for adequate drainage, and shallow floor gutters along the north and south sides of the building direct liquids to blind sumps located outside the southeast and northeast corners of the unit. The pad is accessed by two concrete ramps which roll over the dike area at the east and west ends of the unit. The total capacity for this unit is 153,310 gallons.

\section{Building 9811-1, RCRA Container Storage Unit (OD-8)}

OD-8 is housed in Building 9811-1, which is located within the exclusion area of the Y-12 Plant, at the intersection of West Second Street and K Roads, southwest of Building 9204-4. This unit is used primarily as a staging area for containerized liquid waste until the waste has been characterized to allow transfer to other TSD units. Used oil regulated under the Used Oil Management Standards (40 CFR Part 279) may also be stored at this unit.

The container storage area resides on a $65-\mathrm{x} 75$-foot concrete pad with a 4-inch curb. Loading ramps are located on the north, south, and southeast sides of the unit. A personnel entrance doorway is located at the southeast of the unit near the east loading dock. Hazardous and mixed wastes will be storage at this unit.

Wastes at OD-8 are typically stored in 55-gallon drums, 85-gallon drums, and 330-gallon or 1 600 -gallon polyethylene tanks. The container unit is designed to store approximately 1,000 , 55-gallon drums of waste. Should there be drums in poor condition, 85-gallon overpack drums may be used. The total capacity for this unit is 106,720 gallons.

\section{Containerized Waste Storage Area (CWSA)}

The CWSA is located south of the Y-12 Plant on the east end of Chestnut Ridge. Access to the unit is from the South Patrol Road.

The CWSA consists of three concrete pads measuring 170 feet long and 50 feet wide. The central and eastern concrete pads are covered by open-sided dome tents and store hazardous and mixed wastes. Each concrete pad has a one-foot impermeable dike surrounding it to contain spills. The pads and dikes are sloped toward a 60-gallon sump 
located on the southeast corner of the pads to catch spilled material and for the management of rainwater run-on.

All wastes stored at CWSA must be in approved containers. These include carbon steel drums, original vendor drums, 330-gallon and 600-gallon steel reinforced polyethylene tanks, 6-cubic yard B-25 boxes, and 9-cubic yard dumpsters. The total capacity for all three pads is 810,000 gallons.

\section{B-2 TOPOGRAPHIC MAP}

\section{B-2a General Information}

This section discusses the maps which comply to the requirements of 40 CFR Part 270.14(b)(19) and Tennessee Rule 1200-1-11-.07(5)(a)17. Appendix B-1 contains the maps that show the locations of these units, the general site plan, facility property boundaries, locations of buildings, and the contour of the site to show surface water flow. Due to the large number of units at the Y-12 Plant, several maps have been utilized to give the permit reviewer and writer a clearer understanding of the location of the seven units in this package. The following maps are included in Appendix B-1 and have been provided to facilitate review:

Map 1: The Oak Ridge Y-12 Emergency Facilities Directory shows the general site plan. This map shows the locations of major plant buildings and other structures, the facility property boundaries, the legal boundaries of the site, the locations of portal controlled access roads, exclusion and protected areas of the plant, guard towers and vehicular check points. The plant access roads as well as internal roads are also shown on this map. (Scale: 1 inch $=400$ feet).

Map 2: The Oak Ridge Y-12 RCRA Waste Unit Map illustrates the hazardous waste management units at the Y-12 Plant and the surrounding topography and land uses around the units. The topography of this map includes a contour interval that clearly illustrates surface water flow patterns around the units. The two major surface water streams are illustrated on this map as well as tributaries and intermittent streams feeding East Fork Poplar Creek and Bear Creek. (Scale: 1 inch $=1,280$ feet).

Map 3: The Y-12 Plant Loading and Shipping Docks Map illustrates the loading and unloading docks and shipping docks around the plant. (Scale: 1 inch $=400$ feet). 
Map 4: The Y-12 Plant Floodplain Map shows the East Fork Poplar Creek 100-year floodplain. The 500-year floodplain and maximum probable flood is also shown for the Y-12 Plant. The units in this package (9201-4, 9720-9, 9720-25, 9720-31, 9720-58, 9811-1, and CWSA) are not located within the 100-year floodplain of either Bear Creek or East Fork Poplar Creek. (Scale: 1 inch $=400$ feet).

Maps 5 \& 6: Y-12 Sanitary Sewer System Master Plan and Y-12 Storm Sewer Master Plan Maps. These maps illustrate the sanitary sewer system and the detailed storm water.drainage system for the Y-12 Plant. (Scale: Sanitary Sewers -1 inch $=530$ feet, Storm Sewers -1 inch $=200$ feet).

A variance under Tennessee Rule 1200-1-11-.07(5) is necessary for the required map scale of one inch equals 200 feet for these maps. The size of the Y-12 Plant makes the use of the required scale difficult to utilize for review. A variance has been approved for alternate map scales to be used in the application. A copy of the approval letter is included in Appendix B-1.

Information required to be submitted in this section also includes the following areas:

- Wind rose - The wind rose shown in Figure B-1 indicates wind direction and wind speed taken from the 60 meter point on the West meteorological tower for 1990. This wind rose was chosen as typical for the facilities located on the west end of the plant included in this package. The wind rose in Figure B-2 indicates wind direction and wind speed taken from the 100 meter point on the East meteorological tower for 1990 . This wind rose was chosen as typical of the CWSA Facility located on Chestnut Ridge on the east end of the plant. Appendix B-2 includes information provided by additional wind roses taken from the data gathered from the two meteorological towers located at the east and west end of the plant.

- Injection and withdrawal wells. Not applicable. There are no injection wells or withdrawal wells at the facility. Therefore, there are none shown on the permit maps. 
- Loading and unloading areas. The loading and unloading areas for the container storage areas in this application are illustrated on Map 3 and also in the facility drawings referenced in Section D.

B-2b Additional Topographic Requirements for Land Storage. Treatment and Disposal Facilities and Post Closure Permits for Closed Land Units.

Not Applicable. None of these seven units are hazardous waste land storage, treatment, or disposal units. Additional topographic information is not required of these hazardous waste management units in order to comply with the permit application regulations.

\section{B-3 LOCATION INFORMATION}

The locations of 9201-4, 9720-9, 9720-25, 9720-31, 9720-58, 9811-1, and CWSA at the Y-12 Plant are illustrated in Map 2 of Appendix B-1.

\section{B-3a Seismic Considerations}

Not Applicable. Since the Y-12 Plant is an existing facility and is not located in a political jurisdiction as specified in 40 CFR Part 264, Appendix VI, seismic considerations need not be addressed.

\section{B-3b Floodplain Standard}

Not Applicable. The units in this application are not located within the 100-year floodplain, therefore, this section is not required. 


\section{WIND ROSE for Tower W( $60 \mathrm{~m})$ for $01 / 01 / 90-12 / 31 / 90$}

$\stackrel{\$}{0}$

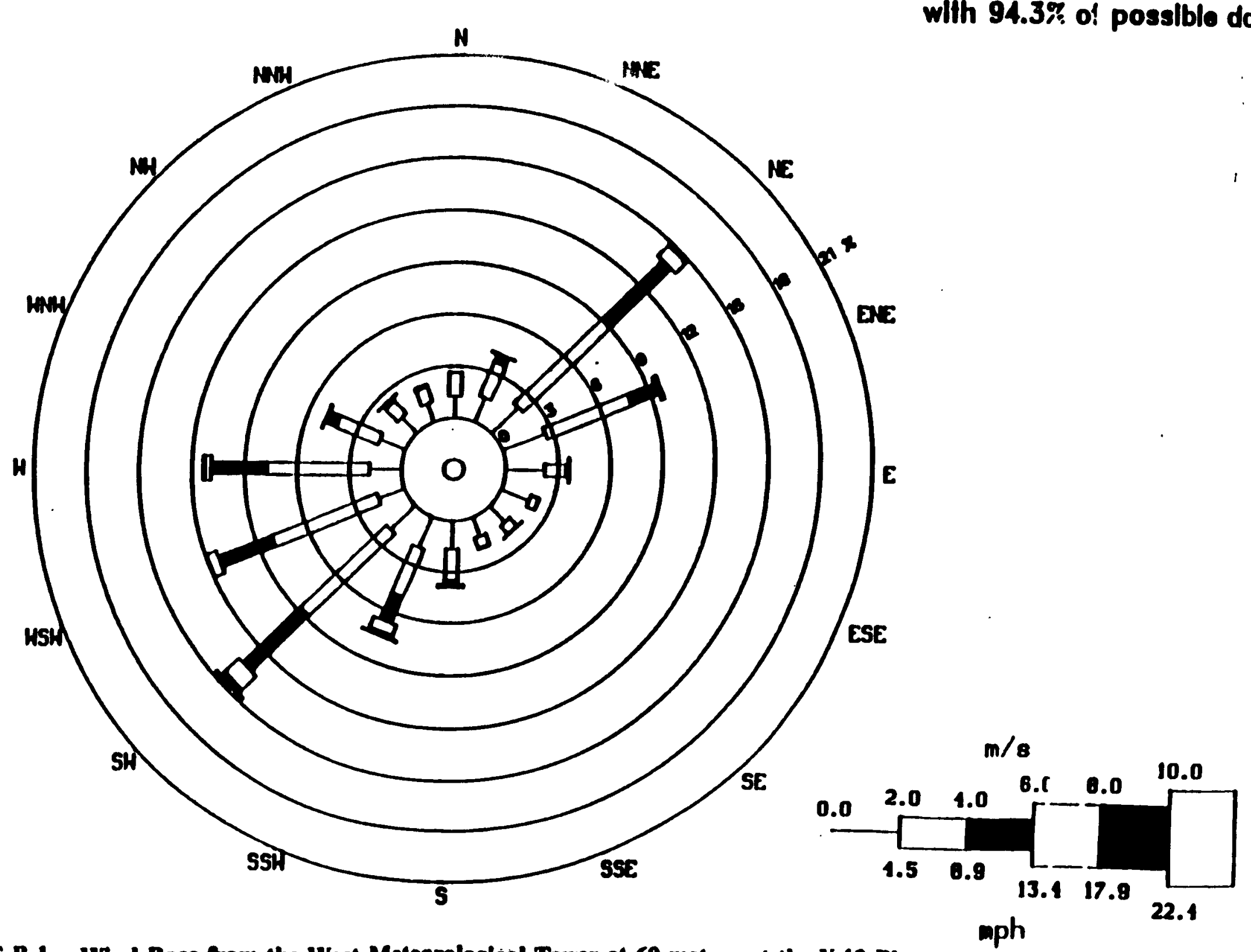

FIGURE B-1 Wind Rose from the West Meteorological Tower at 60 meters at the Y-12 Plant 
WIND ROSE for Tower $E(100 m)$ for 01/01/90 - 12/31/90

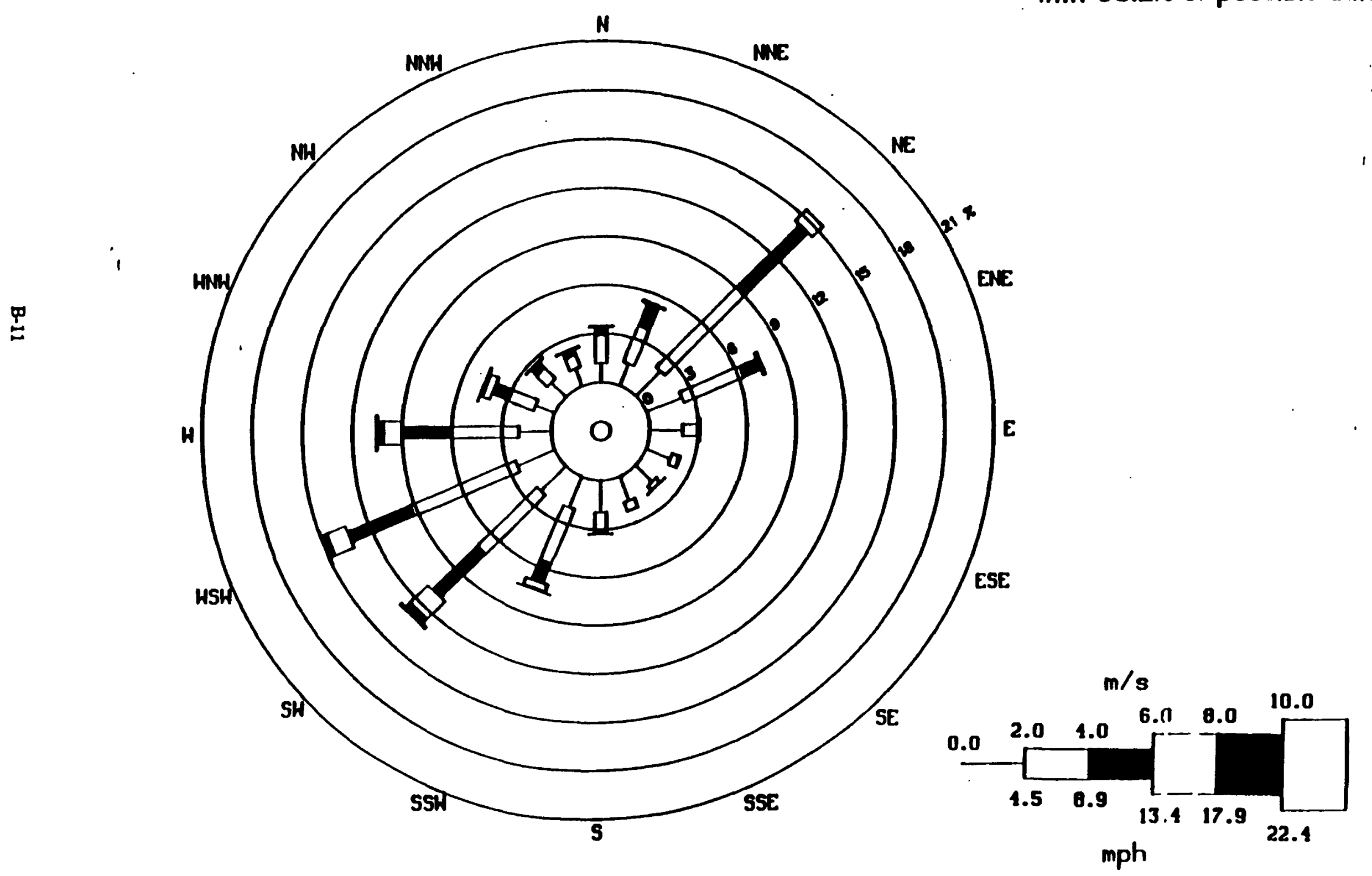

FIGURE B-2 Wind Rose from the East Meteorological Tower at 100 meters at the Y-12 Plant 


\section{B-4 TRAFFIC INFORMATION}

The Y-12 Plant is a major industrial type facility operated under contract to DOE. The road system and its construction are typical of an industrial complex or military facility with numerous production, storage, administrative, maintenance, and utility buildings. These roads can easily bear the weight of the waste-hauling vehicles used for each hazardous waste management unit. Roads are mostly two-way and built of asphalt to accommodate heavy and light traffic including automobiles, light trucks, armored security vehicles, heavy trucks, and tractor trailers (including those used to move nuclear material). There are also some constructed gravel roads capable of carrying the intended traffic. Entry and exit are controlled by guarded, locked gates. Internal traffic is controlled by marked lanes and stop signs at intersections typical of municipal or industrial complex surface streets. Hazardous wastes transported within the Plant or off-site generally consist of dump truck loads of soils and palletized drums, and may periodically include tanker loads of liquids such as oils.

The minimum requirement for construction of existing paved roads at $\mathrm{Y}-12$ is 1.5 to 14.0 inches of asphaltic concrete pavement overlaid on 6.0 to 18.0 inches of compacted aggregate base. All new paved roads are constructed with a minimum of 1.5 inches of asphaltic concrete pavement overlaid on 8.0 inches of stabilized aggregate base course. All paved roads to be used for access to and exit from hazardous waste management unit areas are capable of bearing loads up to allowable state highway limitations.

Other roads used for access to and exit from hazardous waste management unit areas are constructed of crushed stone surfaces and are designed to provide all-weather utilization throughout the Y-12 Plant. These gravel access roads are constructed with a minimum of 6.0 inches of crushed stone on a prepared subgrade and are useable on a year-round basis. These gravel roads are designed to support the anticipated traffic to and from the hazardous waste management unit areas.

The access roads to the units are useable on a year-round basis to authorized personnel only. The estimated traffic volume is twenty four vehicles per week. The types of vehicles typically used during operations are flatbed, pickup, and occasionally tanker trucks. The load bearing capacities of all access roads meet or exceed DOT, Bureau of Highways standards for these vehicles. 


\section{Building 9201-4 Container Storage Area}

Access to Building 9201-4 is from North First Street at the north entrance of the facility.

The building is located at the intersection of "G" Road and North First Street. These streets are typical paved streets and meet the minimum requirements as specified for a Y-12 Plant paved road. These roads are capable of handling traffic associated with the servicing of this facility.

\section{Building 9720-9 Storage Unit}

Access to Building 9720-9 is from Third Street on the south side of the facility. The facility is southeast of the steam plant and approximately 500 yards west of Portal 28. Third Street is designed to meet the minimum construction requirements as specified for paved roads at the Y-12 Plant. The street is capable of handling the anticipated traffic associated with the servicing of this facility.

\section{Classified Container Storage Unit, Building 9720-25}

The Classified Container Storage Unit (9720-25) is located on " $M$ " Road between West Second Street and West Third Street. All these roads are paved roads and are designed and constructed to meet the minimum requirements for the Y-12 Plant paved roads. These roads are capable of handling the associated traffic necessary to service this facility.

\section{RCRA and Mixed Waste Storage and Staging, Building 9720-31}

Building 9720-31 is located on the south side of West Third Street, east of the existing Fire Training Facility, Building 9817. A vehicle maneuvering area is located adjacent to the loading docks. Vehicular access is also provided to the adjacent complexes on the east and west sides of the facility. All roads servicing this facility are paved roads and meet the minimum requirements for $\mathrm{Y}-12$ Plant paved roads.

\section{RCRA and PCB Container Storage Area, Building 9720-58}

Building 9720-58 is a warehouse storage unit located on the north side of Old Bear Creek Road approximately one quarter mile west of the Y-12 Plant. The facility is in close proximity to the OD-9 Waste Facility and south of the Y-12 West End Treatment Facility. The entrance and exit to this facility is by way of Old Bear Creek Road, a paved road constructed to the minimum requirements for Y-12 Plant paved roads. Old Bear Creek Road is designed to handle the anticipated service traffic to this facility. 
Building 9811-1. RCRA Container Storage Unit (OD-8)

The RCRA Container Storage Unit, OD-8, is housed in Building 9811-1 located at the intersection of West Second Street and "K" Roads, southwest of Building 9204-4. Both streets are paved streets designed according to the minimum requirements for paved road construction at the Y-12 Plant. These roads are designed to handle the anticipated traffic associated with the servicing of this facility.

Containerized Waste Storage Area (CWSA)

Access to the CWSA is by way of the South Patrol Road. This road is a paved road designed to carry the anticipated traffic associated with the servicing of this facility. The South Patrol Road is designed according to the minimum requirements for construction of paved roads at the Y-12 Plant. 


\section{SECTION C \\ WASTE CHARACTERISTICS}

This section of the application describes the chemical and physical nature of the hazardous wastes handled and stored in each of the following storage units:

1. Building 9201-4 Container Storage Area

2. Building $9720-9$ Storage Unit

3. Classified Container Storage Unit, Building 9720-25

4. RCRA and Mixed Waste Storage and Staging, Building 9720-31

5. RCRA and PCB Container Storage Area, Building 9720-58

6. Building 9811-1 RCRA Container Storage Unit (OD-8)

7. Containerized Waste Storage Area (CWSA)

This section also includes the waste analysis plan for sampling, testing, and evaluating the waste to assure that sufficient information is available for proper waste management. This information is submitted in response to the RCRA Part B Permit application requirements, as specified in 40 CFR Part 270.14(b)(2); and in Rules Governing Hazardous Waste Management in Tennessee, Rule 1200-1-11-.07(5)(a)2.

\section{C-1 CHEMICAL AND PHYSICAL ANALYSIS}

General Description

Building 9201-4

Building 9201-4 Container Storage Area provides storage for drums (55-gallon) of hazardous and mixed waste resulting from remedial actions, decontamination and decommissioning activities.

The wastes typically consist of mercury-contaminated solids such as soil or insulation that also be defined as mixed waste. The wastes do not contain free liquids.

Building 9720-9

Building 9720-9 Storage Unit provides storage for containers that include 30- or 55-gallon drums, 330- and 600-gallon portable polyethylene tanks, and 96-cubic foot B-25 boxes of hazardous and mixed wastes. Flammable and combustible materials are stored in a separate storage area within the unit. 
Hazardous and mixed wastes typically arrive at this facility in 30- or 55-gallon drums and are ultimately sent to other TSD facilities. The identification, segregation, handling, and management of these wastes are discussed in subsequent sections of this document.

Some wastes stored at Building 9720-9 contain sufficient quantities of PCBs to warrant their management under the Toxic Substances Control Act (TSCA). These PCB wastes are contained in separate containers and are segregated in terms of handling procedures and storage areas. Wastes typically include solids, liquids and sludges such as contaminated soil, waste paint, and oil soaked solids.

\section{Building 9720-25}

Due to the classified nature of the waste materials to be stored in Building 9720-25, a specific listing of chemical species is not presented as part of this permit application. Some general waste analysis information is outlined below. Additional details of the classified waste characteristics are available and on file with the Waste Management Organization at the Y-12 Plant. This information is available for review by " $Q$ " Cleared regulatory personnel.

All of the RCRA hazardous waste material to be stored in Building 9720-25 is stored in containers. The wastes are normally stored in 55-gallon drums although 5- and 30-gallon drums are also used. The wastes may include hazardous, nonhazardous, and mixed wastes; the wastes are typically in solid form.

\section{Building 9720-31}

The RCRA and Mixed Waste Storage and Staging Building stores various wastes and chemicals. Mixed wastes are normally stored in DOT specification 30-, 55-, or 85-gallon drums. Hazardous wastes are usually stored in laboratory-quantity containers such as glass bottles, metal cans, fiber tubes, etc.

The hazardous wastes stored in this facility are partially used, spent, or discarded laboratory reagents, and/or residues of commercial chemicals in their original manufacturer's containers or other containers. Typically, these wastes occur in quantities of grams to several kilograms for solids and milliliters to several liters for liquids. These wastes are sorted and segregated, and compatible wastes are placed in lab-packs. Mixed wastes ordinarily arrive at this facility in 30-, 55-, or 85- gallon drums and are sent to other TSD facilities. The identification, segregation, handling, and management of these wastes are discussed in subsequent sections. 


\section{Building 9720-58}

Building 9720-58 is a warehouse storage unit utilized as a storage and staging area for PCBcontaminated equipment (e.g., transformers, capacitors, and electrical switch gear). The facility also stores nonreactive, nonignitable, RCRA hazardous waste (liquid and solid) that may be defined as mixed waste, such as contaminated clothing, waste paint, and contaminated solvents.

Waste containers received at Building 9720-58 include 30- and 55- gallon drums, 330- or 600gallon portable tanks, 96 cubic feet B-25 boxes, as well as PCB contaminated equipment.

\section{$\underline{\mathrm{OD}-8}$}

OD-8 is a container storage unit that stores hazardous waste consisting of mixtures of waste oils containing non-ignitable, chlorinated organics. The waste oil/solvent/water mixtures are generated by a variety of $\mathrm{Y}-12$ plant maintenance and process operations.

All containers stored at OD-8 are considered to have free liquids. The types of containers stored at OD-8 include 30 - or 55-gallon drums, 85 -gallon overpacks and 330 - or 600 -gallon I portable tanks.

\section{CWSA}

The Containerized Waste Storage Area stores a variety of hazardous waste generated from process, maintenance and laboratory operations on three separate concrete pads.

The wastes stored include hazardous, nonhazardous, and mixed wastes; these wastes are typically in either liquid, sludge, or solid physical forms such as contaminated soils, mercury lamps, waste paint, and contaminated absorbent materials.

The types of containers stored at this unit include 55-gallon drums, 85-gallon overpacks, original vendor drums, 330- or 600-gallon polyethylene tanks and 96-cubic yard B-25 boxes.

\section{Hazardous Characteristics}

The storage units receive and store only the following listed and characteristic wastes as defined in 40 CFR Part 261:

$\begin{array}{ll}\text { Building 9201-4 } & \text { D009 } \\ \text { Building 9720-9 } & \text { All listed and characteristic wastes except K-listed wastes. }\end{array}$ 


$\begin{array}{ll}\text { Building 9720-25 } & \text { F001, F002, F004 - F006, F011 - F039 } \\ & \text { Nonignitable F005 and nonreactive F007 - F010 } \\ \text { D002, D004 - D043 } \\ \text { All nonreactive and nonignitable U- and P-listed wastes. } \\ \text { All listed and characteristic wastes except K-listed wastes. } \\ \text { Building 9720-31 } \\ \text { Building 9720-58 } \\ \text { D002, D004 - D043 } \\ \text { F001, F002, F004 - F006, F011 - F039 } \\ \text { Nonignitable F005 and nonreactive F007 - F010 } \\ \text { All nonreactive and nonignitable U- and P-listed wastes. } \\ \text { F001, F002, F004 - F006, F011 - F039 } \\ \text { Nonignitable F005 and nonreactive F007 - F010 } \\ \text { D002, D004 - D043 } \\ \text { All nonreactive and nonignitable U- and P-listed wastes. } \\ \text { D002, D004 - D043 } \\ \text { F001, F002, F004 - F006, F011 - F039 } \\ \text { Nonignitable F005 } \\ \text { All nonreactive and nonignitable U- and P-listed wastes. } \\ \text { CWSA }\end{array}$

units that do not store ignitable waste.

U- and P-listed wastes are generated occasionally from laboratory, maintenance, and process clean-up or clean-out operations. The quantity and number of shipments of $U$ - and P-listed wastes to each of these storage areas is minimal and infrequent.

A summary of the types of waste stored at these facilities is shown in Table C-l.

\section{Basis for Hazardous Designation}

The hazard designation is based on process knowledge of the on-site generated liquid waste streams and analytical data. The information indicates the presence of F-listed solvents, TCLP criteria solvents and metals, and the possibility of liquid U- and P-listed wastes for materials stored at each of the facilities except for Building 9201-4. 
TABLE C-1. TYPICAL TYPES OF RCRA WASTES STORED

\begin{tabular}{llll}
\hline Location & Parameter & Example $^{1}$ & EPA Waste Code ${ }^{2}$ \\
\hline $9201-4$ & Mercury & $\begin{array}{l}\text { Contaminated soil, insulation } \\
9720-9,\end{array}$ & D009 \\
$9720-31$ & Caustics & $\begin{array}{l}\text { Sodium hydroxide, potassium } \\
\text { hydroxide }\end{array}$ & D002 \\
& Acids & $\begin{array}{l}\text { Sulfuric acid, hydrochloric } \\
\text { acid }\end{array}$ & D002 \\
& $\begin{array}{l}\text { Low flash point } \\
\text { solvents } \\
\text { Reactive or } \\
\text { halogenated organic } \\
\text { compounds } \\
\text { Oxidizing agents }\end{array}$ & $\begin{array}{l}\text { Unsain paraffins } \\
\text { nitrated organics, } \\
\text { halogenated hydrocarbons }\end{array}$ & D001, F003 \\
& $\begin{array}{l}\text { Chlorates, chlorites, chromic } \\
\text { and nitric acid, nitrates, } \\
\text { peroxides, permanganates, }\end{array}$ & D001 \\
& hypochlorites & D003, F001, F002 \\
& & &
\end{tabular}

9720-25 Wastes at this unit are classified.

9720-58, Acids, TCLP metals, Waste oils containing D002, D004-D043, OD-8, chlorinated solvents, residual chemicals $\quad$ F001, F002, CWSA nonchlorinated F004-F006, solvents F011-F039

\footnotetext{
${ }^{1}$ Any of these may be mixed wastes

${ }^{2} \mathrm{P}$ - or U-listed wastes could fall into any of these categories

${ }^{3}$ Waste codes for these categories may also include TCLP metals such as D004 through D011.
} 


\section{C-1a Containers}

The specific parameters to be used for the proper management of the waste may include:

- Concentration of TCLP constituents

- Concentration of PCBs

- Concentration of radiological constituents

- The characteristic of ignitability

- The characteristic of corrosivity

- The characteristic of reactivity

- Waste compatibility with other wastes placed in the container

- Waste compatibility with the container

The safe handling of the waste is of primary importance. Handling of waste will occur only when materials are being transferred to, or removed from, a storage area. Any waste added to a container must be compatible with the container and its existing contents. Compatibility of new wastes with existing inventory will be reviewed by Waste Management personnel. The Waste Coordinator reviews the information provided by the waste generator on a Request for Transfer, Storage, and Disposal of Wastes Form (UCN-2109) (see Appendix C-1) to determine the destination of the waste and its compatibility. Examples of incompatible waste are shown in Appendix C-2. A waste management Facility Engineer determines compatibility of wastes with containers. All equipment used to transfer waste is compatible with the waste. Special handling and storage precautions are required for the management of ignitable wastes.

Waste acceptance criteria will preclude the storage of reactive wastes except at Buildings 9720-9 and 9720-31 (management of incompatible wastes and ignitable wastes is described in Section F-5a and F-5e). Analysis for radiological characteristics will be performed on a case-by-case basis in accordance with DOE procedures.

The presence of radiological contaminants and PCBs must be known to ensure compliance with DOE Orders and TSCA regulations. Certain information such as waste source, TCLP analysis, $\mathrm{pH}$, reactivity, and flash point must be known to assign the proper RCRA waste code designation. This information will be available through knowledge of the process generating the waste or by analysis. 
The wastes must be compatible with the storage and transfer containers and transfer equipment. Waste will typically be handled in steel drums, in portable polyethylene containers, or in tank trucks used at the Y-12 Plant. Engineering tests indicate polyethylene is resistant to attack by oils, chlorinated organics, and nonchlorinated organics at temperatures below $80^{\circ} \mathrm{C}$. The steel drums are constructed of either carbon or stainless steel. Polyethylene drum liners $(4 \mathrm{ml})$ are also available, if needed. The individual generators within the Y-12 Plant determine the compatibility of material to be stored.

\section{C-1b Tanks}

Not applicable. The units covered in this permit application are not storage tanks; therefore, the requirements of this section do not apply.

\section{C-1c Waste Piles}

Not applicable. The units covered in this permit application are not waste piles; therefore, the requirements of this section do not apply.

\section{C-1d Surface Impoundments}

Not applicable. The units covered in this permit application are not surface impoundments; therefore, the requirements of this section do not apply.

\section{C-1e Incinerators}

Not applicable. The units covered in this permit application are not incinerators; therefore, the requirements of this section do not apply.

\section{C-1f Landfills}

Not applicable. The units covered in this permit application are not landfills; therefore, the requirements of this section do not apply.

\section{C-1g Land Treatment}

Not applicable. The units covered in this permit application are not land treatment facilities; therefore, the requirements of this section do not apply.

\section{C-1h Additional Requirements for Land Storage, Treatment, and Storage Facilities} Not applicable. The units covered in this permit application are not land storage, treatment, or disposal facilities; therefore, the requirements of this section do not apply. 


\section{C-2 WASTE ANALYSIS PLAN}

The waste analysis plan is included to describe the procedures for obtaining a waste's chemical and physical characteristics. Characterization is necessary to ensure proper management of the waste and compliance with the EPA land disposal restrictions. Waste analysis parameters and rationale are summarized in Table C- 2 .

Due to the nature of Y-12 operations, all chemicals used in the various operations are identified either from original, manufacturer-labeled bottles or by chemical analysis performed by the individual generator. Mixtures of substances originate in the same fashion, and therefore are identifiable by means of the identifying tag system shown in Appendix C-1.

It is important to note that not all of the wastes stored are hazardous. Some unlisted substances that do not meet the characteristics of a RCRA-defined hazardous waste are also handled as hazardous. In the event the waste characterization indicates unusual properties such as relatively high toxicity, or other nuisance hazards (i.e., irritants, odors, pigmentation, etc.), conventional disposal methods, such as sanitary landfill disposal, would not be used. All hazardous waste will be marked with the words "hazardous waste".

\section{C-2a Parameters and Rationale}

A generator will request transfer of a hazardous waste using a Request for Transfer, Storage, and Disposal of Wastes Form (Form UCN-2109) or a waste stream identification number call-in form. A stream identification number has been assigned to point sources of waste throughout the Y-12 Plant by Waste Management Operations. These waste streams are of uniform consistency. The Waste Coordinator reviews the information provided by the waste generator on form 2109 (see Appendix C-2) to determine the destination of the waste and its compatibility. Examples of incompatible wastes are shown in Appendix C-3. A Waste Management Facility Engineer determines the compatibility of wastes with containers. The container used to transport the waste will also be tagged (UCN-2114A for RCRA hazardous waste and UCN-2114B for nonhazardous waste). Samples of these forms are presented in Appendix C-2. Containers of hazardous waste are marked with the words "Hazardous Waste".

Facility operators will review the generator's information to determine what additional characterization requirements are needed, and to verify that waste acceptance criteria are met. The generator's knowledge of a waste will govern the required analyses to properly characterize a given waste. The generator will be required to document known information 
about the waste such as source, expected constituents, and expected handling or compatibility issues. The rationale behind the selection of the testing parameters is discussed in Sections C-1 and C-3. A copy of a Sample Requisition Request form is shown in Appendix C-2.

\section{C-2b Test Methods}

Waste characterization samples will be prepared according to the appropriate sample preparation protocol. The analytical protocols are specified in Table C-3.

Under the requirements of Tennessee Rule 1200-1-11-.06, adequate laboratory controls must be maintained to assure the proper operation of the facility. These techniques include the preparation and analysis of duplicate, blank, and spiked samples at specific intervals in the analytical operation; these techniques will be followed by Y-12 Plant laboratory personnel.

\section{C-2c Sampling Methods}

\section{Sampling:}

The contents of each container of waste will be characterized by either process knowledge or analysis prior to transfer of the container. The characterization will remain valid until the process changes.

Container sampling of liquids will be performed by use of an all glass Coliwasa drum sampler as described in SW-846. The use of the Coliwasa sampler will provide a representative vertical cross section of the contents of the drum or container and thereby address any anomalies that could develop due to vertical stratification. The procedure used (described in EPA SW-846) is reproduced below:

- Clean Coliwasa.

- Adjust sampler's locking mechanism to ensure that the stopper provides a tight closure. Open sampler by placing stopper rod handle in the T-position and pushing the rod down until the handle sits against the sampler's locking block.

- Slowly lower the sampler into the waste at a rate that permits the level of liquid inside and outside the sampler to remain the same. If the level of waste in the sampler tube is lower inside than outside, the sampling rate is too fast and will produce a nonrepresentative sample. 


\section{TABLE C-2. WASTE ANALYSIS PARAMETERS AND RATIONALE}

\begin{tabular}{lll}
\hline \multicolumn{1}{c}{$\begin{array}{c}\text { Rationale for Testing } \\
\text { Equipment }\end{array}$} & \multicolumn{1}{c}{ Test Parameter } & \multicolumn{1}{c}{ Typically Determined By } \\
\hline Handling and Segregation & Radiation & Analysis/Instrument \\
& Flash Point & Knowledge \\
& Reactivity & Knowledge \\
& Toxic Constituents & Knowledge \\
& Compatibility & Knowledge \\
\cline { 2 - 3 } Off-Site TSD Facility & Chlorinated Solvents & Analysis \\
& PCBs & Analysis \\
& Thorium & Analysis \\
& Aqueous phase pH & Analysis \\
& Beryllium & Analysis \\
& TCLP & Analysis \\
& Ash Content & Analysis \\
& Flash Point & Analysis \\
& BTU & Analysis \\
\hline
\end{tabular}


TABLE C-3. TEST METHODS FOR CONTAINERIZED WASTE

Analyte or Group

Analytical

Method"

Polychlorinated biphenyls

8750,8270

(PCBs)

Nonhalogenated volatile

5030,8740

organics

Nonhalogenated

8250,8270

semivolatile organics

Halogenated volatile

5030,8240

organics

Halogenated semivolatile

8250,8270

organics

Flash point

1010

Gross radiation scan, specific isotopes

Case Specific ${ }^{\mathrm{c}}$

TCLP'

1311

BTU

$240^{d}$

Aqueous phase $\mathrm{pH}$

9040

Thorium

$1635,134^{d}$

Beryllium

7090

Ash Content

$482^{d}$

- Methods referenced from "Test Methods for Evaluating Solid Waste" (SW-846)

- Also refer to 40 CFR Part 261, Appendix II and III

- Testing and methods will be governed by DOE requirements

'Methods from MMES Procedures 
- When the sampler hits the bottom of the waste container, push sampler tube down to close and lock the stopper by turning the T-handle until it is upright and one end rests on the locking block.

- Withdraw Coliwasa from waste and wipe the outside with a disposable cloth or rag.

Solid wastes are sampled using the methods shown in Table C-4. If the solid material is hard to sample, i.e., rags, discarded clothing, personal protective equipment etc., it will not be sampled because it is assumed to be hazardous due to the presence of hazardous waste.

\section{Sample Handling:}

Once the sample is transferred to the sample container, the lid will be closed tightly and taped closed. The exterior of the sample container will be washed, dried, and a sample identification tag attached. At a minimum, the tag will identify the sample, the sample location, time of sample, sampler, preservatives, and a unique sample identification number. The sample containers will be placed in a plastic bag, tied closed, and placed in a sample ice chest with ice or equivalent. An analytical request form and chain-of-custody form will accompany the sample to the laboratory. The analytical request form will also identify the sample number with the tag that is affixed to the sample container(s).

Splitting of concentrated samples for analytical purposes will be performed in the field. Transfer of samples to specified containers for analysis, such as $40 \mathrm{ml}$ septum vials for purge and trap analysis, will be performed in the laboratory.

\section{Reporting:}

All analytical results, generator information, and sample chain-of-custody documentation will be maintained in the operating record.

\section{C-2d Frequency of Analysis}

Sampling and analysis are not conducted for waste in containers which already have proper labels identifying the source of their contents and associated hazard classification. Generators are responsible for analyzing wastes when process changes occur to ensure accurate and up to date information for the storage unit operators. The contents of each unique batch of waste is characterized by either analysis or by process knowledge, before shipment to the storage areas. If analytical results are not available, process knowledge will be used to determine the appropriate storage area to be used for the waste shipment. 
TABLE C-4. SAMPLING EQUIPMENT FOR PARTICULAR WASTES TYPES ${ }^{\star}$

\begin{tabular}{lllllllll}
\hline Waste Type & \multicolumn{7}{c}{ Waste location or container } \\
\cline { 2 - 8 } & Drum & $\begin{array}{l}\text { Sacks and } \\
\text { bags }\end{array}$ & $\begin{array}{l}\text { Open-bed } \\
\text { truck }\end{array}$ & $\begin{array}{l}\text { Closed- } \\
\text { bed truck }\end{array}$ & $\begin{array}{l}\text { Storage } \\
\text { tanks or } \\
\text { bins }\end{array}$ & $\begin{array}{l}\text { Ponds, } \\
\text { lagoons, } \\
\text { and pits }\end{array}$ & $\begin{array}{l}\text { Conveyor } \\
\text { belt }\end{array}$ & Pipe \\
\hline $\begin{array}{l}\text { Moist powders } \\
\text { or granules }\end{array}$ & Trier & Trier & Trier & Trier & Trier & Trier & Shovel & Dipper \\
$\begin{array}{l}\text { Dry powders or } \\
\text { granules }\end{array}$ & Thief & Thief & Thief & Thief & Thief & Trier & Shovel & Dipper \\
$\begin{array}{l}\text { Sand or packed } \\
\text { powders and } \\
\text { granules }\end{array}$ & Auger & Auger & Auger & Auger & b & b & Dipper & Dipper \\
$\begin{array}{l}\text { Large-grained } \\
\text { solids }\end{array}$ & $\begin{array}{l}\text { Large } \\
\text { trier }\end{array}$ & $\begin{array}{l}\text { Large } \\
\text { Trier }\end{array}$ & $\begin{array}{l}\text { Large } \\
\text { Trier }\end{array}$ & $\begin{array}{l}\text { Large } \\
\text { Trier }\end{array}$ & $\begin{array}{l}\text { Large } \\
\text { Trier }\end{array}$ & $\begin{array}{l}\text { Large } \\
\text { Trier }\end{array}$ & Trier & Dipper \\
\hline
\end{tabular}

- Source -- EPA-SW-846; sampling methods described therein will be utilized.

- This type of sampling situation can present significant logistical sampling problems; therefore, sampling equipment must be specifically selected or designed based on site and waste conditions. No general statement about appropriate sampling equipment can be made. 
Characterization necessary to ensure safe handling, regulatory compliance, and compatibility will be required before a waste is transferred off-site. Characterization required for land disposal must be complete before the waste is removed. A waste characterization will remain valid until the generating process changes.

\section{C-2e Additional Requirements for Waste Generated Off-Site}

Not applicable. The units covered in this permit application are not receiving waste generated off-site. Therefore, the requirements for this section do not apply.

\section{C-2f Additional Requirements for Facilities Handling Ignitable, Reactive, or Incompatible} Waste

Waste characteristics have been reviewed for compatibility using a Y-12 Plant hazardous waste compatibility table similar to the list found in Tennessee Rule 1200-1-11-.06, Appendix .06/B, Examples of Potentially Incompatible Waste. See Appendix C-3 and I Sections C-1, C-3, and C-5 for additional information.

Mixing of incompatible wastes will also be prevented by requirements that the on-site generators provide information based on process knowledge or on testing describing the waste contents and characteristics. A compatibility review is an element of the waste acceptance criteria. Waste Management personnel will determine compatibility using waste handling history and other available literature data.

Based on waste handling history, and a review of the incompatible groupings, wastes stored at Buildings 9201-4, 9720-25, 9720-58, OD-8 and CWSA normally will not be reactive, ignitable or incompatible.

On special occasions, incompatible wastes may be stored at Building 9720-25 and CWSA but they would be separated by portable dikes.

Wastes stored at Buildings 9720-9 and 9720-31 can potentially be reactive, ignitable, and incompatible. However, the building design and operation of each of these units helps to ensure that incompatible wastes will not be stored or mixed together. Building 9720-9 has seven areas to allow the segregation of waste into specific waste classifications. Building 9720-31 permits the placement of incoming wastes into the most appropriate of 14 separate storage and staging rooms to prevent mixing of incompatible waste (See Section D-1a(1) for 
specific details). Section F-5a discusses the procedures used to prevent accidental ignition or reaction of the wastes.

\section{C-3 ADDITIONAL WASTE ANALYSIS REQUIREMENTS PERTAINING TO LAND DISPOSAL RESTRICTIONS}

C-3a Waste Characteristics

Specific data must be submitted by the generator to the owner/operator of a treatment or disposal facility to document whether the waste is restricted under the 40 CFR Part 268 requirements. This data will be obtained by analysis of container contents and by knowledge of process. Waste determined to be restricted will be stored separately from non-restricted waste.

\section{C-3a(1) Waste Characteristics - Solvent Wastes and Dioxin-Containing Wastes}

The wastes generated at Y-12 do not contain dioxin or dioxin-containing constituents based on knowledge of the process. The wastes could contain solvents in the F-listed solvent classification. Since the exact composition of the solvent constituents will vary, the wastes will be considered to be a F001, F002, F003, F004, and/or F005 waste. This classification is based on analytical data and on knowledge of current solvent use at Y-12. The wastes stored in each of the units (except Building 9201-4) meet the definition of both a wastewater and a non-wastewater as defined in 40 CFR Part 268.2.

\section{C-3a(2) Waste Characteristics - California List Wastes}

The California List places restrictions on liquid and solid hazardous wastes containing PCBs greater than or equal to $50 \mathrm{ppm}$, over $1,000 \mathrm{ppm}$ halogenated organic constituents, and liquids testing less than or equal to a $\mathrm{pH}$ of 2 . All of the wastes stored at these facilities could contain constituents exceeding the halogenated organic criteria. Based on knowledge of process, liquids testing less than or equal to $2 \mathrm{pH}$ will be stored in containers. PCBs may be present in the waste, but testing will be conducted to ensure that if the regulatory limit for PCBs is exceeded, it will be handled as a TSCA waste. Wastes received in containers will be limited to those waste codes listed in Section C-1.

\section{C-3a(3) Waste Characteristics - First-, Second-, and Third-Third Waste}

Based on knowledge of the waste characteristics, the storage units may receive $P$ and $U$ listed wastes, and TCLP and ignitable wastes, which are subject to land disposal restrictions under 40 CFR Part 268 (Tennessee Rule 1200-1-11-.10). Wastes received in these units will be limited to those waste codes listed in Section C-1. The wastes meet the definition of a 
wastewater and a non-wastewater as defined in 40 CFR Part 268.2. A summary of treatment codes and effective dates is located in Appendix C-3.

\section{C-3b Additional Requirements for Treatment Facilities}

Not applicable. The units covered in this permit application are not treatment facilities; therefore, the requirements for this section do not apply.

\section{C-3c Additional Requirements for Disposal Facilities}

Not applicable. The units covered in this permit application are not disposal facilities; therefore, the requirements for this section do not apply.

C-3d Additional Requirements for Surface Impoundments Exempted from Land Disposal Restrictions

Not applicable. The units covered in this permit application are not surface impoundments; therefore, the requirements for this section do not apply.

C-3e Requirements for Land Disposal Facilities With an Approved Exemption or Extension Not applicable. The units covered in this permit application are not land disposal facilities; therefore, the requirements for this section do not apply. 


\section{SECTION D \\ PROCESS INFORMATION}

This section discusses specific process information for the storage and handling of hazardous wastes at seven separate container storage areas at the Y-12 Plant. These container storage areas can be located on Map 2 in Appendix B-1. The seven areas addressed in this application include the following:

1. Building 9201-4 Container Storage Area

2. Building 9720-9 Storage Unit

3. Classified Container Storage Unit, Building 9720-25

4. RCRA and Mixed Waste Storage and Staging, Building 9720-31

5. RCRA and PCB Container Storage Area, Building 9720-58

6. Building 9811-1 RCRA Container Storage Unit (OD-8)

7. Containerized Waste Storage Area (CWSA)

As required by 40 CFR Part 270.15 and Rules Governing Hazardous Waste Management in Tennessee, Rule 1200-1-11-.07(5)(b)1., this section describes the hazardous waste management processes used at the seven areas.

9201-4

Building 9201-4 Container Storage Area is located in the former southeast switch gear room of Building 9201-4 (Alpha Four). This unit is used to store mercury-contaminated solids such as soil or insulation in containers. The solids may also be defined as mixed waste. The total capacity of the storage area at Building 9201-4 is 17,160 gallons.

\section{$\underline{9720-9}$}

This modified warehouse storage unit is used to store containers of flammable and nonflammable hazardous wastes, PCB-contaminated solid and liquid wastes, and mixed waste with a total capacity of 393,440 gallons.

\section{$\underline{9720-25}$}

The Classified Container Storage Unit is used for storage of classified wastes generated at the Y-12 Plant. The stored materials include hazardous, low-level radioactive, and mixed wastes. The total capacity of the storage area at Building $9720-25$ is 32,465 gallons. 
The RCRA and Mixed Waste Storage and Staging building is used to store a variety of solids, liquids and sludges. The wastes consist of hazardous, nonhazardous, and mixed wastes. The total capacity of the storage area at Building $9720-31$ is 46,000 gallons.

$\underline{9720-58}$

The RCRA and PCB Container Storage Area is a warehouse located in close proximity to OD-9 at the west end of the Y-12 Plant. The unit is used to store PCB-contaminated equipment and hazardous waste. The total capacity for the storage area at Building 9720-58 is 153,310 gallons.

$\underline{\mathrm{OD}-8}$

This building is a storage unit used primarily as a staging area for containerized liquid waste until the waste has been analytically identified to permit transfer to bulk storage. Total proposed capacity of this unit is 106,720 gallons.

\section{CWSA}

The Containerized Waste Storage Area consists of three concrete pads. The central and eastern pads are covered by open-sided dome tents and store low-level radioactive waste, hazardous waste, and mixed wastes. Total capacity for storage on all three pads is 810,000 gallons.

\section{D-1 CONTAINER SYSTEMS}

This Section describes the container storage capabilities of each of the container storage units.

D-1a Containers with Free Liquids

All containers at Buildings 9720-9, 9720-25, 9720-31, 9720-58, OD-8, and CWSA could potentially have free liquids. The containers at Building 9201-4 do not have free liquids.

The wastes stored at Building 9201-4 are classified by the Waste Code D009. Wastes stored at Buildings 9720-9 and 9720-31 include all listed and characteristic wastes except for K-listed wastes. Wastes stored at Buildings 9720-25, 9720-58, OD-8, and CWSA include D002, D004 through D043 and all nonreactive and nonignitable listed waste except for K-listed waste. 
D-1a(1) Basic Design Parameters, Dimensions and Materials of Construction

All seven container storage areas have bases made of concrete. The concrete floors within the diked area are free of cracks and gaps and are sufficiently impervious to contain spills until the collected material is detected and removed.

9201-4

A typical plan view of the container storage area is shown in Figure D-1. The container 1 storage area measures 55 feet by 18.5 feet inside a 6-inch rollover dike. The base of the container storage area is the concrete floor of Building 9201-4. The floor is covered with two layers of ten mil PVC lining. All drums are on pallets double-stacked and contain no free liquids. The capacity for this storage area is 17,160 gallons.

$\underline{9720-9}$

The building is approximately 240 by 50 feet. A typical layout is shown in plan view in 1 Figure D-2. It is equipped at each end (west and east) with a personnel door, a vehicle access slide door, and a ramp. The front (south side) contains two personnel doors with one leading into the west end, and one leading into the east end. Inside the building, separating the west and east sides, is a floor-to-roof wall containing a personnel door, a roll-up door, and a ramp. The building has a concrete floor coated with a chemical resistant sealing compound to ensure containment of any leaks. Building 9720-9 is divided into two sections:

West End. The west end stores hazardous, PCB-contaminated, and mixed wastes. It has been subdivided into a storage room for flammable and combustible materials, aisle space, and five storage areas for additional segregation of incompatible wastes divided by two-inch roll-over dikes. The two-inch roll-over dikes makes possible the movement of containers using a forklift over the dikes. The storage capacity of the west end is 195,000 gallons.

East End. The east end is currently undergoing modification to the floor and dike which prevents the storage of waste on this end. When the modifications are complete, however, the storage capacity will be 198,440 gallons. 


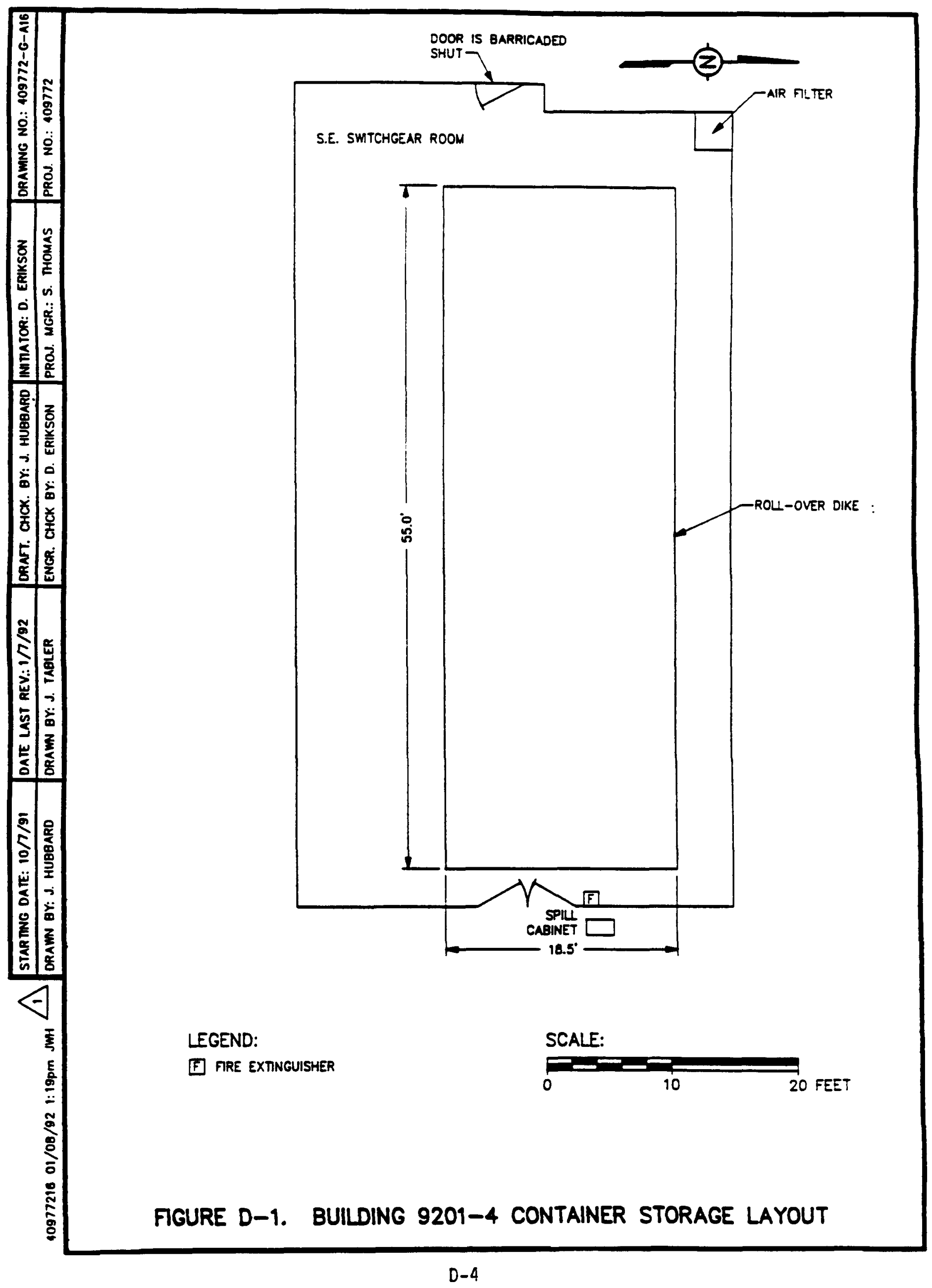




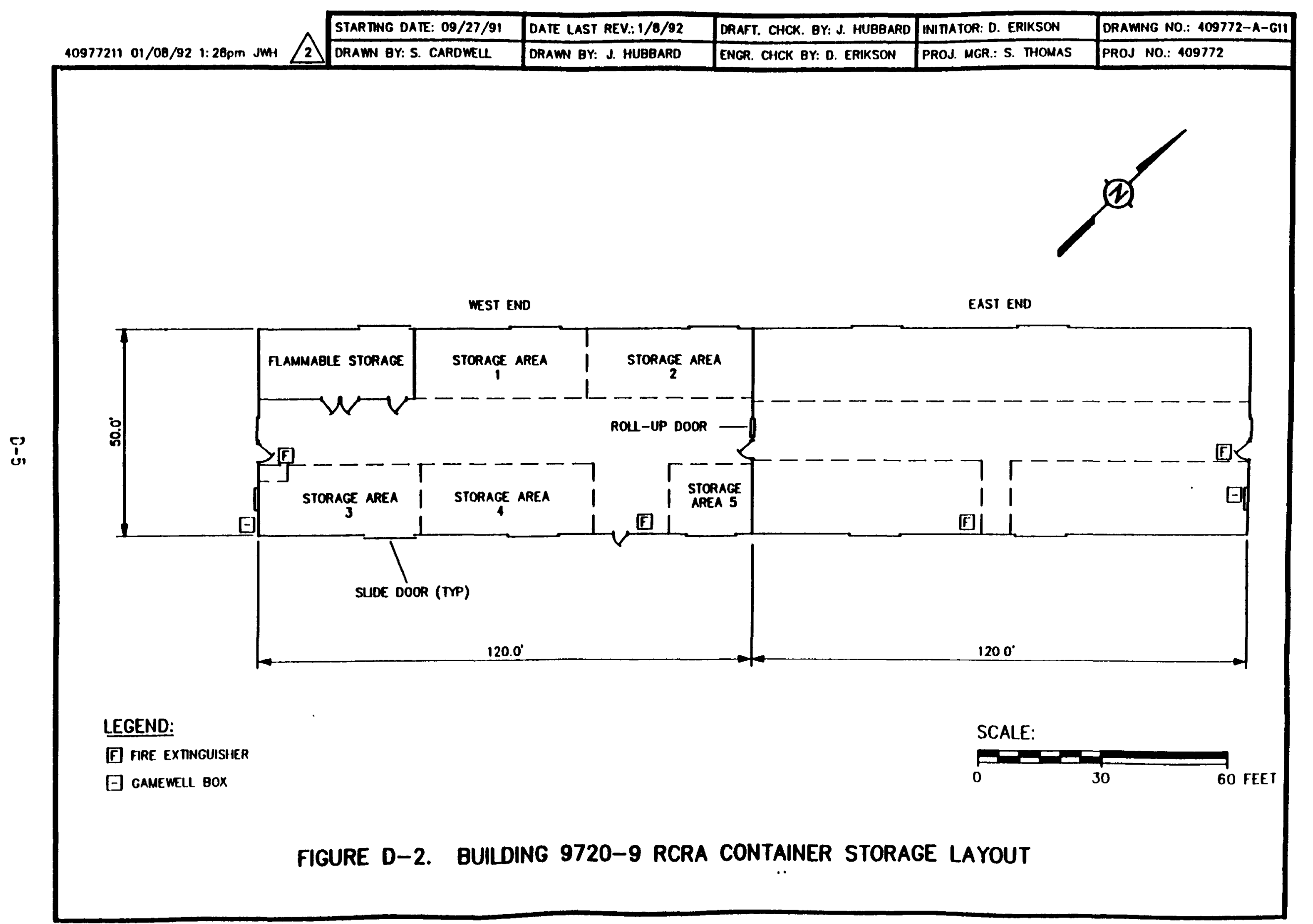


$\underline{9720-25}$

A typical plan view of Building 9720-25 is shown in Figure D-3. The RCRA storage area I for classified hazardous waste is located in the northwest corner of the building. The diked area measures 39.9 by 27.9 feet with 6 inches of monolithically poured concrete curbing. The floor is constructed of concrete and is sealed with a waterproof, fire-resistant, impervious coating. The storage capacity of this area is 32,465 gallons.

\section{0-31}

The building shown in Figure D-4 is constructed of lightweight, concrete block masonry walls and partitions. It has a pre-cast concrete roof deck and a concrete floor slab on grade. The building is partitioned into seven storage and seven staging rooms to segregate classes of material, as shown in Figure D-4. The building has covered loading docks and an asphalt access and truck maneuvering area. The staging rooms have an approximate total floor area of 3,000 square feet and a volume of 31,000 cubic feet. The storage rooms have an approximate total floor area of 3,700 square feet and a volume of 40,000 cubic feet. Two doors are provided on opposite ends of each room. Each storage and staging room has direct access to the loading dock. Because drums are moved by hand trucks and forklifts, ramps are provided for all entrances. Materials are handled manually and with special care in the storage and staging rooms.

Waste classifications such as caustics, acids, low-flash-point solvents, etc. are assigned to wastes as they are received at this facility. Incompatibles are segregated into separate rooms for proper storage.

The building has a 6-inch concrete floor slab on grade. The floors in all of the rooms slope to the center of the room, where a blind sump is located to collect any spills. An epoxy coating has been applied to the floors and a wall wainscot in all of the rooms. If any cracks occur in the concrete, they will be caulked to contain leaks and spills. The storage capacity for the building is 46,000 gallons.

$\underline{9720-58}$

A typical plan view of the RCRA and PCB Container Storage Area is shown in Figure D-5. I The unit structure consists of a metal roof with temporary plastic sides over a 98 - by 39 -foot concrete pad. The concrete pad is coated with a chemically resistant epoxy and surrounded by a 6-inch curb. The pad is gently sloped from the center to the north and south sides for adequate drainage, and shallow floor gutters along the north and south sides of the building 


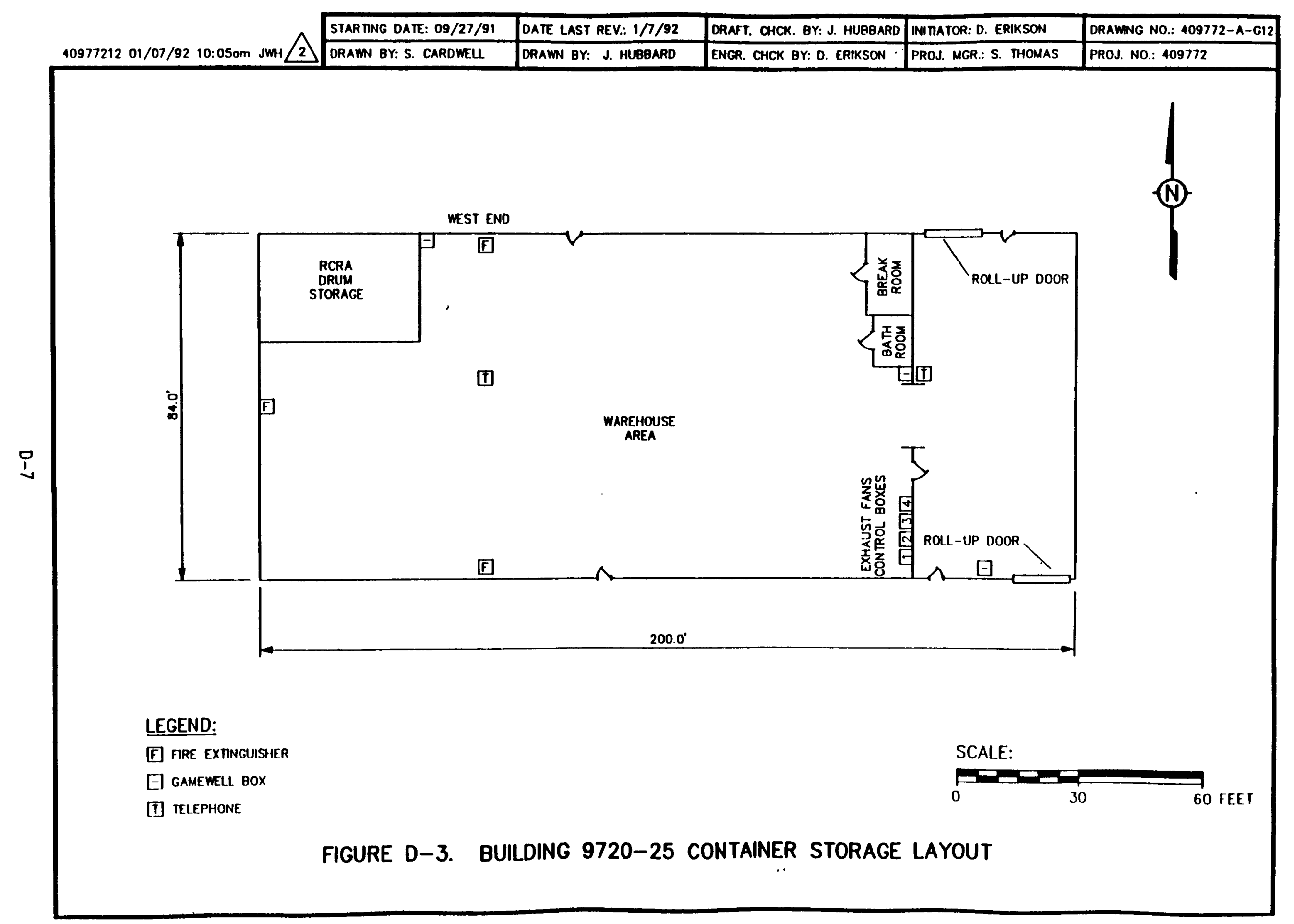




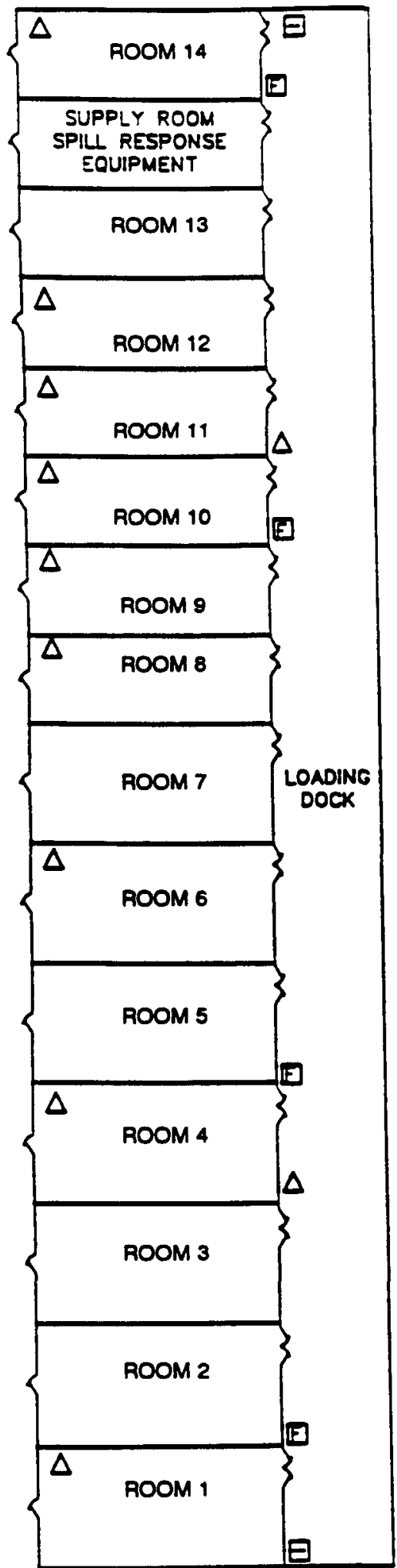

PARKING LOT

MAXIMUM OUANTTY:

2055 GAL. DRUMS/

7 STAGING ROOMS.

ROOMS 8 THROUGH ROOM 14

MAXIMUM OUANTTTY:

9655 GAL DRUMS/

7 STORAGE ROOMS.

ROOMS 1 THROUGH ROOM 7

LEGEND:

F FIRE EXTINGUISHER

$\square$ GAMEWELL BOX

$\triangle$ SAFETY SHOWER/

EYE BATH

SCALE:

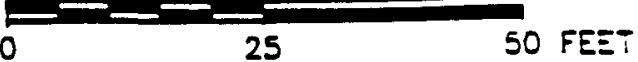

FIGURE D-4. BLDG. 9720-31 CONTAINER STORAGE LAYOUT 


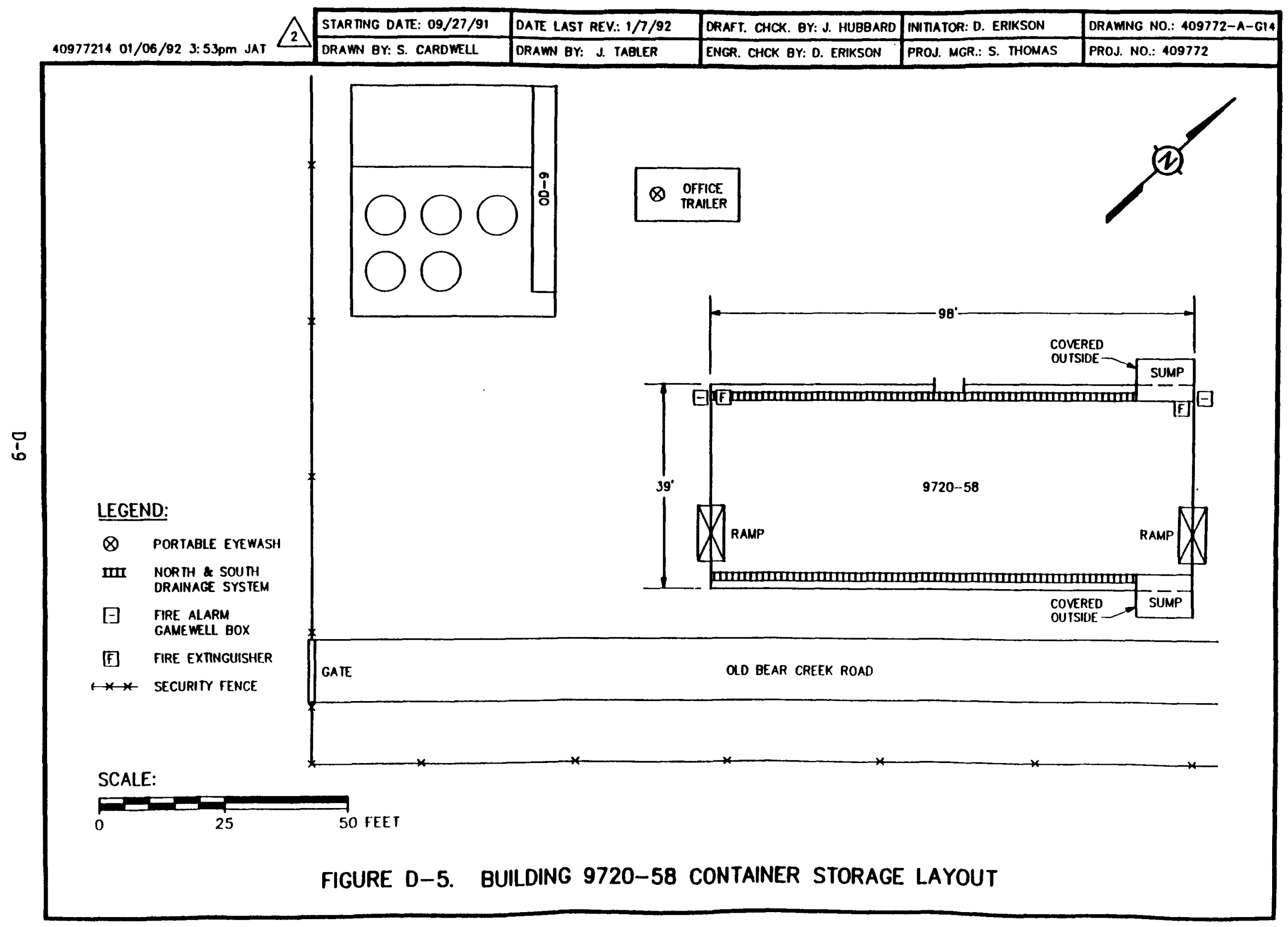


direct liquids to blind sumps located within the dike area and extending outside the southeast and northeast corners of the facility.

The pad is accessed by two concrete ramps which roll over the dike area at the east and west ends of the facility however. The storage capacity for the building is 153,310 gallons.

\section{$\underline{\mathrm{OD}-8}$}

A typical plan view of OD-8 is shown in Figure D-6. It resides on a 65 - by 75 -foot concrete 1 pad with a four-inch curb. The pad is 8 inches thick and overlies a 6-inch layer of crushed stone. The floor is sloped toward two 50-gallon sumps. An epoxy coating has been applied to the concrete that is compatible with the waste stored. Loading ramps are located on the north, south, and east sides of the facility. A personnel entrance is located at the southeast of the facility near the east loading dock. Since the dike height does not meet minimum height requirements (six inches) of TSCA regulations, $\mathrm{PCB}$-contaminated liquids will not be stored at OD-8.

One north-south aisle is provided at the center of the facility to permit movement of a forklift. The facility contains 21 bays for stacking containers. The storage capacity for this building is 106,720 gallons.

\section{CWSA}

A typical layout of the Containerized Waste Storage Area is shown in Figure D-7. CWSA I consists of three concrete pads measuring 170 feet long by 50 feet wide. The central and eastern concrete pads are covered by open-sided dome tents and store low-level radioactive, hazardous, and mixed wastes. The west pad is currently uncovered and not used. The floors of the pads have been coated with an epoxy coating that is compatible with the wastes stored. Each concrete pad has a one-foot impermeable dike surrounding it to contain spills. The pads and dikes are sloped toward a 60-gallon sump located on the southeast corner of the pads to catch spilled material and for the management of rainwater run-on. The storage capacity for this area is 810,000 gallons.

D-1a(2) Description of How Design Promotes Drainage or How Containers are Kept from Contact with Standing Liquids in Containment System

As was noted in Section B, all seven of the container storage areas are located in buildings or structures that are covered by roofs. Additional information in included in Section D. $1 \mathrm{a}(4)$. 


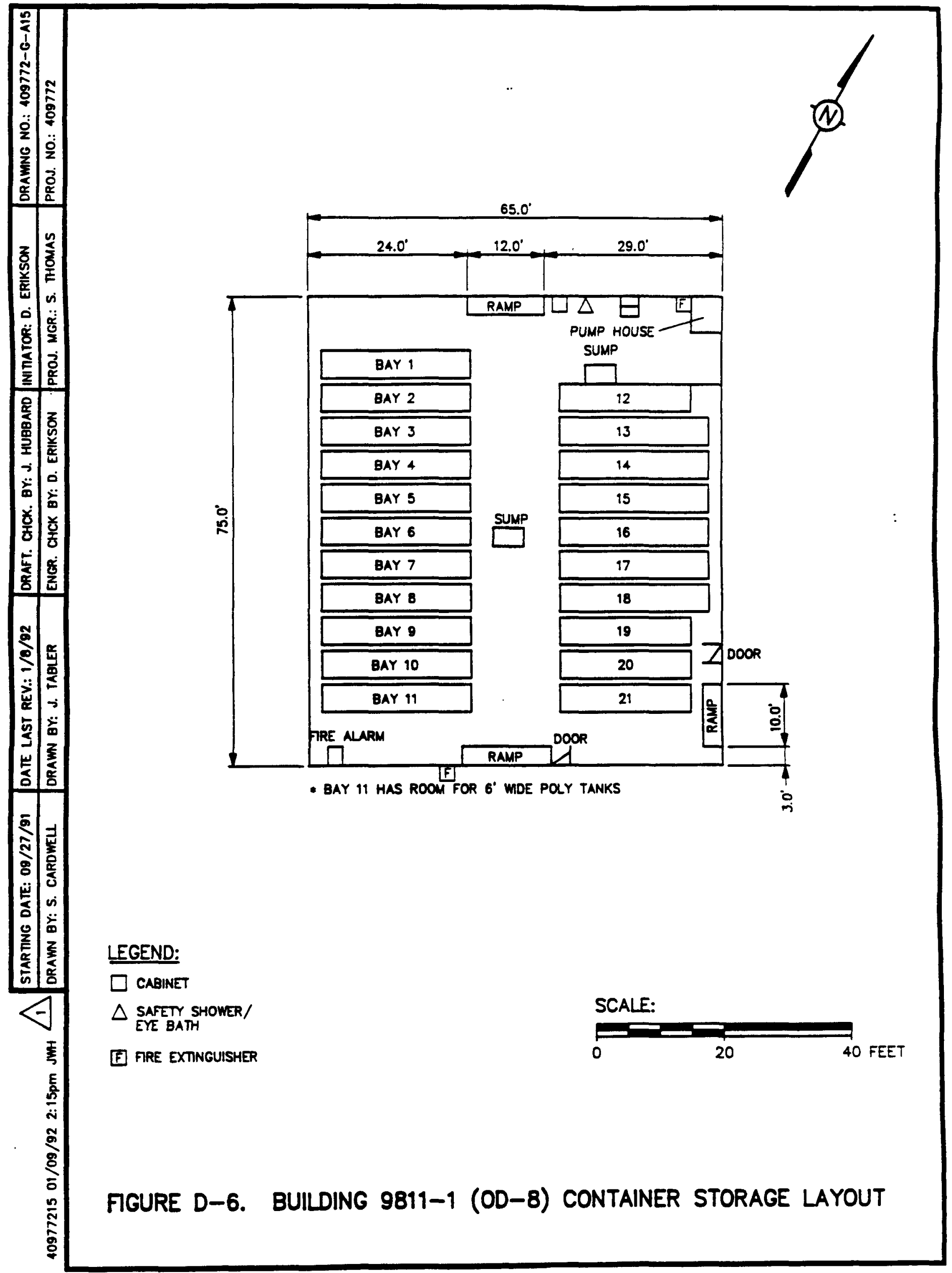




\begin{tabular}{|c|c|c|c|c|c|}
\hline & STAR ING DATE: $10 / 7 / 91$ & DATE LAST REV: : 1/9/92 & DRAFT. CHCK. BY: J. HUBBARD & INIIATOR: D. ERIKSON & DRAMNG NO.: $409772-A-617$ \\
\hline $4097721701 / 10 / 92$ 1:03pm JWH & ORAWN BY: J. HUBBARD & DRAWN BY: J. TAGLER & ENGR. CHCK BY: D. ERIKSON & PROJ. MGR.: S. THOMAS & PROJ. NO.: 409772 \\
\hline
\end{tabular}
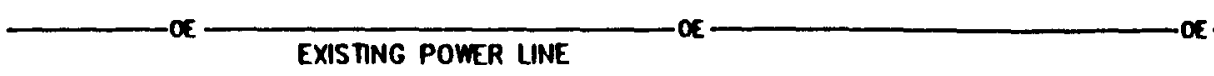

$\mathbf{0} \mathbf{2}$

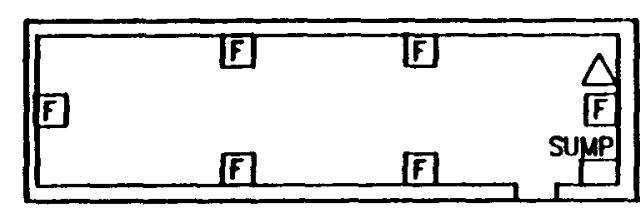

$\mathbf{o c}$
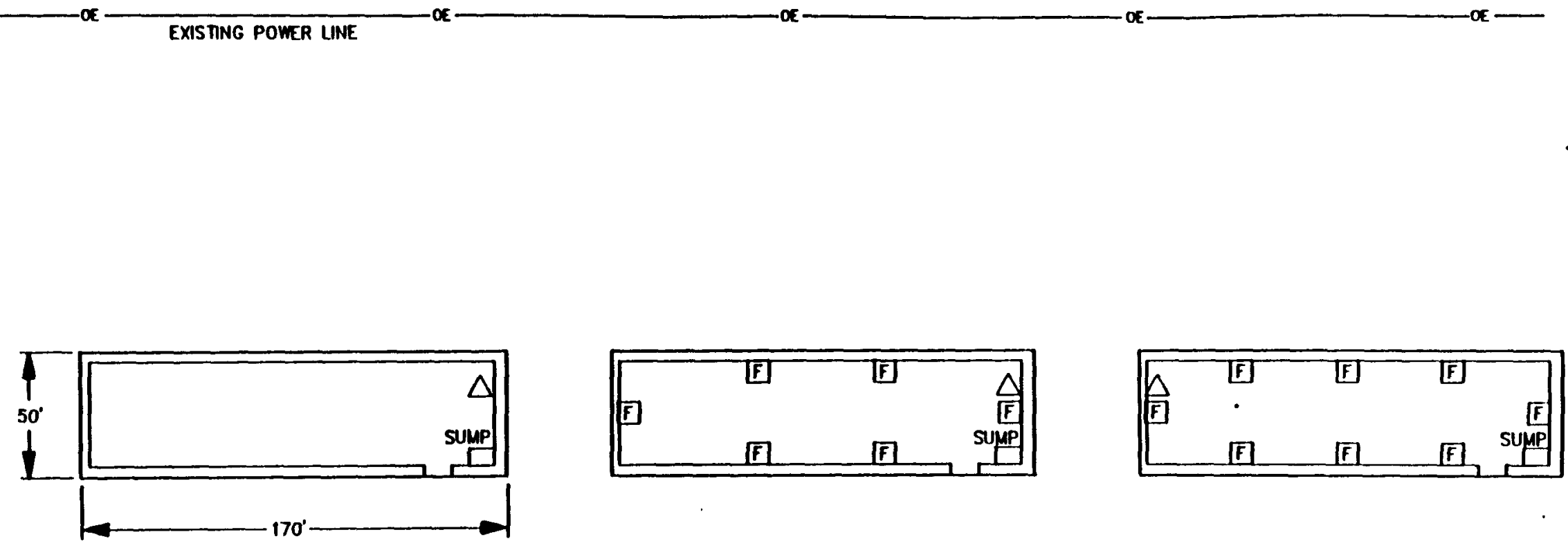

EAST CHESTNUT RIDE SOUTH PATROL ROAD

LEGEND:

$\triangle$ SAFETY SHOWER/ EYE BATH

(F) FIRE EXTNGUISHER
NOTE:

THE THREE CONTAINER STORAGE PADS ARE IDEN ICAL IN SHAPE. EACH HAS A DESIGN CAPACITY OF 270000 GALLONS.
SCALE:

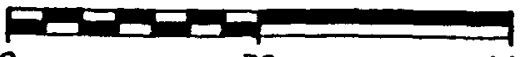

0

70

FGURE D-7. CONTAINERIZED WASTE STORAGE AREA LAYOUT 


\section{$\underline{9201-4}$}

No drums containing free liquids are stored at this unit.

\section{$\underline{9720-9}$}

The drums will be stored upright on pallets to prevent contact with any standing liquids. A 2-inch high, noncombustible, liquid-tight, corrosion resistant, dike is installed around all storage bays, excluding area No. 5, to prevent the flow of liquids to adjoining areas and to contain any spills within its own bay until they are properly removed. The use of individual dikes to segregate and contain spills or leaks precludes the use of an alternative sloped drainage system. The building's 6-inch perimeter dike will provide additional protection for containment of spilled material within the building.

\section{$\underline{9720-25}$}

The existing storage facility includes a watertight, moisture proof roof. Drummed wastes are stored upright on pallets to prevent possible contact with standing liquids. The secondary containment systems allow for spilled, leaked, or accumulated liquids to be pumped into portable drums immediately upon detection.

\section{0-31}

The sealed concrete floors within each segregated storage area are sloped from the peripheral curbs at pitches varying from one-quarter of an inch to one inch per foot to centrally located blind sumps which have dimensions of 2 by 2 by 2 feet (i.e., eight cubic feet or about 60 gallons). Thus, if an entire drum of liquid were spilled during handling, the contents would immediately drain to the center sump and be contained.

Spills of more than one drum are accounted for in the capacity of the curbed containment volume. The height of the curbs is 6 inches. They were sized assuming operation of all sprinkler heads within the room for a 15 -minute period. The drums in the building are stacked a maximum of two high, normally on pallets, in the appropriate storage areas. The sloped floors and sumps, as well as pallets, provide the primary means of separating the containers from leaks of spilled wastes.

$\underline{9720-58}$

All drums are stored upright on pallets to minimize contact with standing liquids. The concrete pad is coated with a chemically resistant epoxy and surrounded by a 6-inch curb. The pad is sloped from the center to the north and south sides to allow drainage of any 
leaks or spills. Shallow floor gutters along the north and south sides direct liquids to blind sumps located at the southeast and northeast corners of the unit.

\section{$\underline{\text { OD-8 }}$}

The drum storage area pad has a four-inch curb around its perimeter. The curb is ramped at entrance locations. Two sumps are provided in the pad. Each sump is capable of holding 50 gallons of liquid and is covered with grating capable of supporting the forklift traffic. The pad is sloped to assure proper drainage to the sumps. Liquids in the sump will be collected upon their discovery.

The drum storage area has a loading dock at the southeast corner of the pad. Dock height is $\mathbf{4 0}$ inches above finished grade (asphalt or concrete). The storage building has adequate ramps and aisle space for loading, unloading, inspection, spill control, and decontamination operations.

Forklift operators are trained to handle drums without rupturing them or causing spills. The drums are stored not more than two high on pallets.

\section{CWSA}

Drummed material is normally stored on pallets to minimize contact with any accumulated liquids. Each concrete epoxy coated pad has a one-foot impermeable dike surrounding it to contain spills. The pads and dikes are sloped toward a 60-gallon sump located at the southeast corner of each pad to collect any spilled material and/or rainfall run-on.

D-1a(3) Capacity of the Containment System Relative to the Number and Volume of Containers to be Stored

Secondary containment calculations and container arrangement/stack height are shown in Appendix D-2. A summary of permitted and operating capacity versus secondary containment capacity for each area is shown in Table D-1. 
TABLE D-1. CONTAINER STORAGE AREA CAPACITIES AND SECONDARY CONTAINMENT CAPACITIES

\begin{tabular}{ccc|}
\hline Storage Area Name & Storage Area Capacity & $\begin{array}{c}\text { Secondary Containment } \\
\text { Capacity }\end{array}$ \\
\hline $9201-4$ & 17,160 & 3,337 \\
$9720-9$ & 393,440 & 39,344 \\
$9720-25$ & 32,456 & 3,246 \\
$9720-31$ & $46,000^{\mathrm{a}}$ & $19,600^{\mathrm{a}}$ \\
$9720-58$ & 153,310 & 15,331 \\
OD-8 & 106,720 & 10,672 \\
CWSA & $810,000^{\mathrm{b}}$ & $84,502^{\mathrm{b}}$ \\
\hline
\end{tabular}

- Total of 14 rooms

b Total of 3 pads 


\section{1-4}

The maximum volume to be stored in containers is 17,160 gallons. No liquid spills will occur since the unit stores no drums with free liquids.

9720-9

The containment system consists of bays segregated by 2 -inch high, noncombustible, liquidtight, corrosion resistant dikes. Flammable wastes are stored in a separate area, while other wastes are stored in the general area. Total containment volume is based on the building dimensions of $240 \times 48$ feet. The containment capacity of the west end is 19,500 gallons and the containment capacity of the east end is 19,844 gallons.

\section{0-25}

The storage area at Building $9720-25$ is not expected to contain liquid waste; however, no more than 13,640 gallons of solid or liquid waste is allowed. The total containment volume of the curbed area is 4,447 gallons. Therefore, the containment system is capable of containing in excess of the regulatory requirement of 10 percent for container storage areas.

\section{0-31}

The largest single container, which may be present in any one of the storage rooms at this unit, is an 85-gallon overpack drum. This large drum might be used to protect a leaking or damaged 55-gallon drum and would not contain more than 55 gallons of waste material.

The presence of a 6-inch concrete curb around each storage room combined with a 2- by 2- by 2 -foot sump provides in a typical storage room 10.5 by 32 feet in size, a containment capacity of more than 160 cubic feet (or about 1,200 gallons). It is difficult to predict the maximum number of containers which might be stored in this type of room at any one time. However, if such a room were packed full with drums stacked two high, allowing for aisle space, it is estimated that about 96 drums (of 55 gallons each) could be accommodated. The 96 drums would be equivalent to 4,800 gallons, assuming each contains 50 gallons of waste with 5 gallons of headspace. Ten percent of this volume, 480 gallons, would not exceed the room's containment capacity of 1,600 gallons. The containment system thus provides capacity for somewhat more than 10 percent of the waste that could possibly be present under assumed adverse conditions, i.e., "worst case" conditions. In a typical staging room 14.5 by 32 feet in size, a containment capacity of more than 200 cubic feet (or about 1,600 gallons) is provided. At most, 20, 55-gallon drums may be stored in a staging room at one time, or the equivalent of 1,000 gallons, assuming each drum contains only 50 gallons of 
waste and has 5 gallons allotted for headspace. The containment capacity provided is more than adequate for the staging rooms.

9720-58

The maximum volume of liquid to be stored in containers is 98,500 gallons based on 1,790 55-gallon drums. Spills which occur in the container storage area will flow down slope to the surface drains, into the sumps located nearby. The RCRA container storage capacity is approximately 153,310 gallons. Refer to Figure D-5 for additional information.

\section{$\underline{\text { OD-9 }}$}

The maximum volume of liquid to be stored in containers is 55,000 gallons based on 1,000 55-gallon drums. Spills which occur in the container storage area will flow down gradient into the sumps. In the unlikely event that the sump would overflow, the drum storage area is completely enclosed by a 4-inch curb and will hold 10,672 gallons. Refer to Figure D-6 for additional information.

\section{CWSA}

The maximum volume of liquids to be stored in containers is 270,000 gallons on each pad for a total of 810,000 gallons. Spills which occur on the pad will flow down gradient into the sump. In the event that the sump would overflow, the pad is completely enclosed by a onefoot dike and will hold 27,514 gallons each. Refer to Drawing D-7 for additional information.

\section{D-1a(4) Provisions for Preventing or Managing Run-On}

Each of the units, with the exception of CWSA, is completely enclosed with walls and roof to minimize the accumulation of rainfall in the storage area. The two covered pads at CWSA have shown minimal accumulation of rainwater (less than 10 gallons) even during major storm events. In addition, the ground floor for each of the units is raised and curbed to prevent run-on from precipitation events and diversion drains direct water to the sides of the CWSA pads for drainage down the hill.

D-1a(5) How Accumulated Liquids can be Analyzed and Removed to Prevent Overflow Accumulated liquids would be present at each of the units only as a result of a spill or a leak from one or more containers within the diked areas or from precipitation at CWSA. 
If a liquid is observed by the operator, a sample is collected for $\mathrm{pH}$ and conductivity. If the results indicate a spill or leak has occurred, a sample will be taken and analyzed to determine the waste identification before transfer to the appropriate tank or container. See Section $C$ for sampling analysis methods.

Removal of spilled liquids will be accomplished by use of portable pumps or by the use of adsorbents depending on the quantity of material present. Accumulated liquids will be removed immediately after their discovery. See Section F-2c and G-5f for additional information in the event of a release.

\section{D-1b Containers Without Free Liquids}

All of the waste stored at Building 9201-4 and some of the wastes stored in containers at each of the other units will be without free liquids. Hazardous wastes will be clearly identified with the words "Hazardous Waste". The wastes at Buildings 9720-9, 9720-25, 9720-31, 9720-58, OD-8, and CWSA are generated from spill cleanup or lab discards and normally consist of soil, discarded personnel protective equipment, and other solid material contaminated with the same waste described in Sections C-1 and D-1a. The wastes stored at Building 9201-4 are from remedial activities involving solid materials. All of the designated storage areas have secondary containment structures.

\section{D-1c(1) Container Management}

Most wastes at these units are stored in DOT-specification 55-gallon drums. Wastes may also be received in 30-gallon drums, 330- or 600-gallon portable tanks, B-25 boxes, or small laboratory bottles. Several steps have been taken to prevent hazards during loading and unloading operations. Drum handling operations typically take place when drums are placed into storage or during loading for shipments to off-site TSD facilities. To minimize the potential for accidents involving other vehicles and pedestrians, traffic flow is limited around the loading area during operations. All drum handling equipment used (carts, lifts, etc.) are specifically designed to transport or lift drums safely and without damage. Ramps have been constructed to allow wheeled vehicles (carts, forklifts, etc.) easy access to containers while still providing containment for spilled liquids.

All waste containers in storage are sealed at all times except during filling operations (for solvents and other liquids), packing for shipment, or for sampling purposes. Containers are handled (i.e., moved, loaded onto trucks, filled, etc.) only under the direction of th. hazardous waste supervision. Funnels appropriately designed and fabricated are used with 
17E drums for pouring liquids. Solvent drums, or drums holding other volatile liquids, are always filled in such a manner that three to four inches headspace is kept (approximately five gallons or 10 percent of the drum's volume) to allow for expansion.

Most containers used for hazardous wastes are intended for use once only. In other words, they are used only once for storage of hazardous waste and then discarded. They are usually shipped with the waste and disposed of at the final destination. Some may be emptied and discarded, as are solvent drums after a bulk shipment for disposal. Some drums used for hazardous waste storage may be reconditioned, or cleaned (by rinsing or other appropriate measure) or have contained material that is known to be compatible with the waste to be added. Polyethylene drum liners $(4 \mathrm{ml})$ are used for wastes not compatible with steel drums. Drums containing incompatible wastes are generally segregated by DOT hazard class and whenever possible, drums containing wastes known to be incompatible are stored in different areas or kept separate via portable dikes.

All containers are observed during packing and loading operations. Also, all containers are inspected weekly on an individual basis for deterioration, corrosion, leakage, etc.; a listing, illustrative of the inspection technique for this facility, is given in Section F-2. Any container that does not pass inspection is replaced within 24 hours with one that meets the proper requirements.

The storage areas have aisles for the passage and maneuver of forklift trucks accessing the segregated waste storage area. This aisle is kept clear of drums or equipment; drums are sorted in the designated segregated areas.

Aisle spacing is typically 3 to 5 feet with adequate aisle space maintained at all times. Typical operating layouts of each of the areas is shown in Appendix D-2.

Drums may be stacked and are stored on pallets. The maximum number of drums that could be stored in each unit is based on the containment capacity of the diked area.

\section{D-1c(2) Requirements for Ignitable or Reactive Wastes and Incompatible Wastes} The wastes stored at Buildings 9201-4, 9720-25, 9720-58, OD-8, and CWSA are not ignitable, reactive or incompatible (see Section C-1). 
A variety of chemical wastes are stored in Buildings 9720-9 and 9720-31. Some of these are classified as ignitable or reactive wastes and incompatible wastes. Each of the buildings is located more than 15 meters ( 50 feet) from the facility's property line. See Map 2 for the exact location of each unit.

The use of noncombustible, liquid-tight, corrosion resistant, dikes prevents the flow of liquids to adjoining areas. The diking complies with the guidelines set forth in RCRA.

Wastes are segregated according to the categories shown in Table C-1 into individually diked subareas within the buildings (see Figures D-2 and D-4) to prevent close proximity of wastes likely to react. Thus acids and bases are kept separate, and ignitable or reactive wastes are physically segregated into designated areas. No chemical treatment or mixing of different wastes is performed in the buildings. However, small (5- to 10-gallon) containers of the same waste may be transferred into drums. Incompatibles are not placed in the same container through proper identification. Precautions are also taken not to place waste in unwashed containers that previously held incompatible material.

\section{D-2 TANK SYSTEMS}

Not applicable. The units covered in this permit application are not tank systems; therefore, the requirements of this section do not apply.

\section{D-3 WASTE PILES}

Not applicable. The units covered in this permit application are not waste piles; therefore, the requirements of this section do not apply. 


\section{SECTION E \\ GROUNDWATER MONITORING}

Groundwater monitoring is not required for Buildings 9201-4, 9720-9, 9720-25, 9720-31, 9720-58, OD-8, and CWSA as per the requirements of 40 CFR Part 264, Subpart F and Tennessee Rule 1200-1-11-.07(5)(c) which exclude tank and container storage areas from the groundwater monitoring requirement. 


\section{SECTION F \\ PROCEDURES TO PREVENT HAZARDS}

This section of the application provides information concerning procedures to prevent hazards required by 40 CFR Part 270.14 and Rules Governing Hazardous Waste Management in Tennessee, Rule 1200-1-11-.07(5)(a). The following subject areas are addressed in this section: general security provisions, inspection schedules and requirements, preparedness and prevention requirements, and prevention of accidental ignition or reaction of ignitable, reactive, or incompatible wastes at Buildings 9201-4, 9720-9, 9720-25, 9720-31, 9720-58, OD-8, and CWSA.

\section{F-1 SECURITY}

\section{F-1a Security Procedures and Equipment}

The Y-12 Plant maintains security procedures and equipment that prevent the unknowing entry of persons or livestock onto the active portion of the facility which minimizes the possibility for unauthorized entry. The 24 hours per day, 7 days per week surveillance system is utilized at the Y-12 Plant, and one or more barriers are present to control entry.

\section{F-1a(1) 24-Hour Surveillance System}

The Y-12 Plant is a DOE facility which produces and handles nuclear materials. It is a fully secure facility completely surrounded by a barbed wire-topped, chain-linked fence eight feet in height. A security force and centralized security operations oversee the entire Y-12 Plant. The facility is continuously manned 24 hours per day, 7 days per week by armed guards from the Y-12 Plant Security Department. The perimeter of the facility is patrolled at intervals day and night via a system of patrol roads.

Most gates for pedestrian and vehicular access are manned by armed guards and only authorized personnel are admitted. All individuals entering the Y-12 Plant must be authorized by the Y-12 Plant Security Department.

\section{$\underline{9201-4}$}

Building 9201-4 is located on First Street and is within the fully secured (exclusion) area at the west end of the Y-12 Plant. Access to this area is through continuously manned (24 hours per day) portals where ID badges are required. Proper clearance must be obtained to enter the exclusion area or access is denied. 
Once in this exclusion area, the storage area in Building 9201-4 is locked at all times except during operations in which authorized personnel are present. The responsible facility operator controls the keys and access inside the storage area.

\section{0-9}

Building $9720-9$ is located on Third Street within the barbed wire-topped chain link fence southeast of the Steam Plant near portal 28, see Map 2, Appendix B-1. Building 9720-9 is located outside of the exclusion area but access is controlled through manned portals.

Access into Building 9720-9 is through personnel doors or the roll-up vehicle door located on the east and west end of the building. These doors are locked and keys and access are managed by the responsible building operator.

\section{0-25}

Building $\mathbf{9 7 2 0 - 2 5}$ is located on M Street within the exclusion area where access is denied to unauthorized personnel. In additional the building is locked and keys and access are managed by the responsible facility operator.

\section{0-31}

Building 9720-31 is located on West Third Street in the south west portion of the Y-12 Plant see Map 2, Appendix B-1. This facility is outside of the exclusion area but access is controlled by guarded portals. All doors to the storage rooms are locked and keys and access is managed by the responsible facility operator.

\section{$\underline{9720-58}$}

Building 9720-58 is located on Old Bear Creek Road and is within the barbed wire-topped chain linked fence at the west end of the Y-12 Plant, see Map 2, Appendix B-1. Access to this area is provided by four fenced gates. Two of the fenced gates are southeast and southwest of Building 9720-58 where the fence crosses Old Bear Creek Road. The other two fenced gates are northeast of Building 9720-58 near the West End Treatment Facility which is also located within this fenced area. The fenced gate located west of Building 9720-58 is locked at all times and has a concrete barrier immediately west of it to further discourage entrance. The other three entrances are beyond a guard portal on Bear Creek Road which requires one person in each vehicle to possess a permanent badge in order to obtain access beyond that point. 
$\underline{\mathrm{OD}-8}$

OD-8 is located at the intersection of West Second Street and $\mathrm{K}$ Roads within the exclusion area see Map 2, Appendix B-1. Access to OD-8 is provided through a personnel door located on the east side or a vehicle door on the south side of the building.

\section{CWSA}

The CWSA is located on South Patrol Road outside of the exclusion area, see Map 2, Appendix B-1. Access to this unit is controlled by guarded portals. There is an eight foot high chain linked fence topped with barbed wire that surrounds the area where the CWSA is located.

\section{F-1a(2) Barriers and Means to Control Entry}

Controlled access through guarded portals limits the entry to the container storage units in this permit application. Additional controls such as eight foot chain-liked fences topped with barbed wire and locked doors prevent the unauthorized entry to the units. See Section F-1a(1) for additional information.

F-1a(2)(a) Barrier

An eight foot high chain-linked fence topped with barbed wire completely surrounds all the units in this permit application. See Section F-1a(1) for additional information.

\section{F-1a(2)(b) Means to Control Entry}

Guarded portals control all access to the units both inside and outside of the exclusion area of the Y-12 Plant. Doors and gates to the units are locked during off-shift hours or when the authorized facility operator is not present. The gates or doors may be opened on offshifts and weekends to allow overtime work. See Section F-1a(1) for additional information.

F-1a(3) Warning Signs

Individual RCRA facilities on the Y-12 premises are posted with signs stating:

"Danger--Authorized Personnel Only"

or a similar message which indicates that only authorized personnel are allowed to enter and that entry onto the active portion can be dangerous. No languages other than English are necessary for the signs at this plant. All signs are located at each entrance and are legible from a distance of at least 25 feet and are visible from all angles of approach. 
Signs are located on the sides of each unit that may be approached. They are either mounted on the unit or on boundary control devices at the edge of each unit.

\section{F-1b Waiver}

Not applicable. The Y-12 Plant does not request a waiver of the regulations stated in 40 CFR Part 264.14(a) and Tennessee Rule 1200-1-11.06(2)(e) concerning security of these units.

\section{F-1b(1) Injury to Intruder}

Not applicable. A waiver is not required; therefore, this section is not applicable.

F-1b(2) Violation Caused by Intruder

Not applicable. A waiver is not required; therefore, this section is not applicable.

\section{F-2 INSPECTION SCHEDULE}

\section{F-2a General Inspection Requirements}

Because of the diverse activities and the specialized nature of activities at the Y-12 Plant, authority and responsibility for inspections, record-keeping, and remedial actions are delegated among various groups and operating facilities. Inspection activities include coverage of the areas of fire control, emergency and spill response, health and safety, radiological safety, and specialized equipment unique to operations within the Y-12 Plant.

For the purposes of this application, the general inspection schedule for areas and/or equipment related to hazardous waste regulations is given in Table F-1 in Appendix F-1. The schedule identifies the types and frequencies of inspections required by RCRA regulations, including monitoring equipment, safety and emergency equipment, security devices, and operating and structural equipment. Operating procedures exist for the units in this package which specify types of inspection logs, frequency, and record-keeping requirements.

\section{F-2a(1) Types of Problems}

Types of problems to be looked for when inspecting monitoring equipment, safety and emergency equipment, security devices, operating and structural equipment, and areas subject to spills are listed in Tables F-1 and F-2 in Appendix F-1. 


\section{F-2a(2) Frequency of Inspection}

Inspection frequencies for plant-wide equipment and supplies are included in Tables F-1 and F-2 in Appendix F-1.

\section{F-2b Specific Process Inspection Requirements}

Inspection of each unit is conducted according to the inspection schedules in Appendix F-1 and/or the operating procedures. Results of each inspection are recorded on inspection log sheets. Information requested on the log sheets includes the inspector's name and title, date and time of inspection, items of inspection, types of problems encountered, status of the items, observations, and the date and nature of repairs and remedial actions. Typical problems encountered with each item on the inspection schedule are listed on the log sheet and serve as a reminder to the inspector to ensure a complete inspection. The inspector is required to check the status of each item and to indicate whether its condition is acceptable or unacceptable. If the status of a particular item is unacceptable, appropriate and complete information is recorded, including date and nature of repairs and remedial action. Evaluation and/or correction of unacceptable items will be initiated within 24 hours of the inspection.

\section{F-2b(1) Container Inspection}

Inspections of the container storage areas are conducted according to the general description in Section F-2b and the inspection schedule in Table F-2 in Appendix F-1. Table F-2 also includes the daily inspection requirement for loading and unloading areas when in use. The container storage areas are inspected on a weekly basis and recorded on the inspection log in Table F-4 in Appendix F-2.

\section{F-2b(2) Tank System Inspection}

Not applicable. The units covered in this permit application are not tank systems; therefore, the requirements of this section do not apply.

\section{F-2b(3) Waste Pile Inspection}

Not applicable. The units covered in this permit application are not waste piles; therefore, the requirements for this section do not apply.

\section{F-2b(4) Surface Impoundment Inspection}

Not applicable. The units covered in this permit application are not surface impoundments; therefore, the requirements for this section do not apply. 
F-2b(5) Incinerator Inspection

Not applicable. The units covered in this permit application are not incinerators; therefore, the requirements for this section do not apply.

\section{F-2b(6) Landfill Inspection}

Not applicable. The units covered in this permit application are not landfills; therefore, the requirements for this section do not apply.

\section{F-2b(7) Land Treatment Inspection}

Not applicable. The units covered in this permit application are not land treatment units; therefore, the requirements for this section do not apply.

\section{F-2b(8) Miscellaneous Unit Inspections}

Not applicable. The units covered in this permit application are not miscellaneous units; therefore, the requirements for this section do not apply.

F-2b(9) Subpart AA - Inspection Requirements (Organic Emissions from Process Vents) Not applicable. The units in this permit application are not required to be monitored for organic omissions from process vents.

\section{F-2b(10) Subpart BB - Inspection Requirements (Organic Emissions from Equipment Leaks at RCRA Units)}

Not applicable. The units in this permit application are not required to be monitored or inspected for organic omissions from equipment leaks.

\section{F-2c Remedial Action}

The Waste Storage and Shipping Operations (WSSO) Department is responsible for taking remedial actions when inspections reveal problems. Operational supervisors and responsible technicians are responsible for initiating requests for required maintenance activities when unacceptable conditions or problems are discovered during inspections of these facilities. If inspections reveal that non-emergency maintenance is needed, it will be completed as soon as possible in accordance with a schedule noted in the log, to preclude further damage and reduce the need for emergency repairs. The inspector instructs the responsible maintenance organization on the remedial actions to be taken to correct these deficiencies. 
If a problem is imminent or has already occurred during the course of an inspection or any time between inspections, remedial actions will be initiated within 24 hours. In the event of an emergency involving the release of hazardous constituents to the environment, efforts will be directed toward activating the contingency plan, containing the hazard, removing it, and subsequently decontaminating the affected area. Refer to Section G, Contingency Plan, for further details.

\section{F-2d Inspection Log}

Container storage areas are inspected and information is recorded on the log sheets shown in Appendix F-2, Table F-4. The log includes spaces for the date of the inspection, identity of the inspector, and the specific items to be inspected and provides for records of remedial action.

After an inspection, each log sheet is filed at the responsible WSSO Department Head's I office, and these records are kept in accordance with Recordkeeping, Section J.

\section{F-3 WAIVER OF PREPAREDNESS AND PREVENTION REQUIREMENTS}

The Y-12 Plant does not request a waiver of the preparedness and prevention requirements. Requirements of this subpart are primarily addressed in Sections D, F, and G of this application.

\section{F-3a Equipment Requirements}

Additional internal and external communication systems, emergency equipment, and fire control equipment are discussed in Section G, Contingency Plan.

\section{F-3a(1) Internal Communications}

The Y-12 Plant does not request a waiver of the preparedness and prevention requirements. Requirements of this subpart are primarily addressed in Sections D, F, and $G$ of this application.

\section{F-3a(2) External Communications}

The Y-12 Plant does not request a waiver of the preparedness and prevention requirements. Requirements of this subpart are primarily addressed in Sections D, F, and G of this application. 


\section{F-3a(3) Emergency Equipment}

The Y-12 Plant does not request a waiver of the preparedness and prevention requirements. Requirements of this subpart are primarily addressed in Sections D, F, and $G$ of this application.

\section{F-3a(4) Water for Fire Control}

The Y-12 Plant does not request a waiver of the preparedness and prevention requirements. Requirements of this subpart are primarily addressed in Sections D, F, and $G$ of this application.

\section{F-3b Aisle Space Requirement}

The Y-12 Plant does not request a waiver of the preparedness and prevention requirements. Requirements of this subpart are primarily addressed in Sections D, F, and G of this application.

\section{F-4 PREVENTATIVE PROCEDURES, STRUCTURES, AND EQUIPMENT}

\section{F-4a Unloading Operations}

Wastes received at the units are delivered in drums, polyethylene tanks, B-25 boxes or original containers. Drums will normally be on pallets and are unloaded with a forklift. Ramps are provided to facilitate safe movement of containers from the transport vehicle to the appropriate storage space. In addition, adequate aisle space is maintained at all times. These unloading operations are conducted by trained facility personnel. Additionally, the container storage areas have curbed sides and slopes to facilitate the drainage of any spills into the containment basin at each of these locations. Further information concerning spill or rupture or other emergency situations is found in Section G, Contingency Plan.

\section{F-4b uㅡ-Off}

Run-off from the units is highly unlikely since the container storage areas are enclosed in buildings and have containment basins surrounding the containers. In addition precipitation is prevented from entering all buildings except the CWSA where it may be blown in from the sides. The precipitation collected in the containment areas at the CWSA will be analyzed and disposed of accordingly based on the results.

\section{F-4c Water Supplies}

By preventing run-off as described in F-4b, water supply contamination is prevented. Groundwater contamination is prevented by eliminating the discharge of hazardous materials 
onto the unprotected ground. Additionally, any spills or leaks would be contained by the design described in F-4b.

\section{F-4d Equipment and Power Failure}

Operations at the units that will be affected if a facility power outage occurs are the lighting, pumps, and piping freeze protection. If the lights, pumps, or the freeze protection system should fail, personnel would cease loading, unloading, or transferring waste. The activities can be resumed when power is restored. No problems are anticipated from such a power interruption.

In the event of equipment failure such as truck or forklift breakdown, operations will be halted until a replacement is secured or repairs are completed. The majority of the operation is passive storage and containment. All plant-wide emergency alarms have backup power generators to insure continual power availability.

\section{F-4e Personal Protection Equipment}

The equipment appropriate for employees at specific facilities and areas of the plant is specified by the Plant Industrial Hygiene (IH) and Radiation Protection (RP) personnel. The plant IH and RP personnel utilize hazardous chemical data, material safety data sheets, and radiological information necessary to determine the appropriate type of personnel protection needed. They also consider the characteristics of the waste types to be handled, including toxicity, ignitability, reactivity, corrosivity, routes of exposure, and other information. IH and RP personnel report to the Plant Shift Superintendent whenever the Contingency Plan is implemented, and they assist him in specifying the protective equipment for affected personnel such as fire fighters, rescue teams, spill cleanup personnel, and equipment decontaminators. Available equipment is listed in Section G. See Section H, I Personnel Training, for a description of employee training in this subject area.

Personnel exposure to hazardous waste is minimized through the use of protective equipment as well as by safe handling practices. At a minimum, personnel in the storage areas wear safety glasses and safety shoes. If actual handling of hazardous waste is necessary, personnel will wear the above items plus gloves of the appropriate type such as cotton, nitrile rubber, or latex rubber, as specified by the IH Department for the specific chemical or chemical class being handled as well as work boots with steel inserts and, when needed, respirators. Whenever required, other protective equipment is available, including but not limited to, hard hats with face shields, impermeable coveralls, self-contained 
breathing apparatuses, and acid suits. However, the actual requirement for specific safety equipment for the protection of personnel in the event of a spill or leak is determined on a case-by-case basis.

Good handling practices to prevent worker exposure include transferring hazardous wastes carefully, using proper equipment such as drum lifts, funnels, pumps, and pump adapters as well as sealing all containers before moving them. All operations are performed by fully trained laborers under the direction of the operating supervisor or the technician, who are familiar with the personnel protection procedures to be followed for the material being handled.

\section{F-5 PREVENTION OF REACTION OF IGNITABLE, REACTIVE, AND INCOMPATIBLE WASTES}

F-5a Precautions to Prevent Ignition or Reaction of Ignitable or Reactive Wastes

The wastes stored at Buildings 9201-4, 9720-25, 9720-58, OD-8, and CWSA are neither reactive nor ignitable.

The wastes stored at Buildings $9720-9$ and $9720-31$ are reactive and ignitable. Both Buildings 9720-9 and 9720-31 receive laboratory wastes from all areas of the Y-12 Plant. Although ignitable and/or reactive wastes may not be present at all times, standard operating procedures are appropriate for the management of ignitable and reactive wastes. Accurate identification of waste at the source of generation ensures that wastes are managed so as to prevent reactions, fires, or releases of waste constituents.

Only wastes compatible with the containers are stored. Therefore, no reactions will occur and the only source of ignition will be external to the containers. Nonsparking tools and equipment are used in both buildings, and personnel use nonsparking clothing and personnel protective equipment. Sources of ignition or reaction, including open flames, smoking, cutting and welding, hot surfaces, frictional heat, sparks, and spontaneous ignition are prohibited in the area. "No Smoking" signs are conspicuously placed inside the buildings and at all entries. Cutting, welding, or other operations in which a potential hazard exists will only be permitted in this area if a special work permit has been issued. The special work permit will list all precautions necessary to prevent ignition of the waste. 
Materials for each facility are separated according to the waste categories listed in Section C-1.

All facility rooms are separated by fire walls. Two-hour fire partitions separate flammable material handling rooms from the remaining areas. At Building 9720-31, rooms containing reactive metals and flammable or combustible wastes are not adjacent to each other. The flammable liquids and combustibles storage rooms are located on the outer ends of the building structure (See Figure B-3). Blow-out panels are installed in the exterior walls to release explosive forces. Doors at the Flammable Liquid Staging Room and Flammable Liquid Storage Rooms at both buildings are U.L. labeled assemblies and have appropriate "No Smoking" and "No Open Flame" signs. Adequate aisle space requirements will be observed in these rooms.

Proper ventilation of each room is maintained at all times to provide employee comfort and to prevent the accumulation of hazardous vapors which may result from normal operation or from accidental spills or leaks. All electrical equipment in the flammable liquids rooms are explosion-proof.

Freeze protection and heat protection will prevent container rupture due to freezing or fume generation due to elevated temperatures. Temperatures are maintained between $50^{\circ}$ and $105^{\circ} \mathrm{F}$.

Both buildings are heated and ventilated. At Building 9720-31, one spark-proof wall exhauster is provided in each room for ventilation. The storage room exhausters provide approximately $2000 \mathrm{cfm}$ and staging room exhausters provide approximately $1500 \mathrm{cfm}$. A wall louver with insect screen and counterbalance-type backdraft damper is provided in the south outside wall of each room. Each wall exhauster is operated from a switch located just outside the north door of the respective room. A thermostat, located in the room, can automatically override the switch and energize the wall exhauster if the temperature exceeds the set point. Electric unit heaters with wall-mounted thermostats are provided in each room except the flammable liquid rooms. The staging room unit heaters are $7.5 \mathrm{~kW}$. The storage room unit heaters are $10 \mathrm{~kW}$. This ventilation operates automatically, and the temperature is controlled by a wall thermostat. The staging flammable liquids room has a $15 \mathrm{~kW}$ heating unit and $275 \mathrm{cfm}$ wall blower. The storage flammable liquids room has a 15 $\mathrm{kW}$ heating unit and a $500 \mathrm{cfm}$ wall blower. Both buildings are equipped with explosion- 
proof lights and other fixtures in all areas classified as hazardous. Electrical equipment for these areas is kept to a minimum.

F-5b General Precautions for Handling Ignitable or Reactive Waste and Mixing of Incompatible Waste

There are no ignitable, reactive, or incompatible wastes accepted at Buildings 9201-4, 972025, 9720-58, OD-8, and CWSA. A compatibility review will be conducted by waste management personnel before incompatible wastes are moved into a unit.

There are ignitable, reactive, and incompatible wastes accepted at Buildings $9720-9$ and 9720-31. Sections F-5a, F-5c and F-5d discuss the precautions taken to prevent reactions which:

1. Generate extreme heat or pressure, fire or explosions, or violent reactions;

2. Produce uncontrolled toxic mists, fumes, dusts, or gases in sufficient quantities to threaten human health or the environment;

3. Produce uncontrolled flammable fumes, dusts, or gases in sufficient quantities to pose a risk or fire or explosions;

4. Damage the structural integrity of the device or facility; or

5. Through other like means, threaten human health or the environment.

Segregation of wastes on the basis of generator information minimizes placement of incompatible wastes in the same storage or staging area, and will prevent heat or pressure or cause violent reactions or other uncontrolled releases to the environment. All containers remain closed so that fumes, dusts, or gases are not released. Wastes are characterized in accordance with the waste analysis plan in Section C.

F-5c Management of Ignitable or Reactive Wastes in Containers

The wastes stored at Buildings 9201-4, 9720-25, 9720-58, OD-8, and CWSA are neither reactive nor ignitable. 
The wastes stored at Buildings 9720-9 and 9720-31 may be reactive and ignitable. Section F-5a discusses how reactive and ignitable waste containers at this facility are protected from materials or conditions which could cause them to react or ignite. Wastes are characterized in accordance with the waste analysis plan in Section C. Also, see Section D-1(c)(2).

Map 2 in Appendix B-1, Topographic Map, demonstrates that Buildings 9720-9 and 9720-31 are each located at least 15 meters (50 feet) from the site property boundary.

\section{F-5d Management of Incompatible Waste in Containers}

As discussed in Section F-5a, incompatible wastes stored at Buildings 9720-9 and 9720-31 are segregated into separate storage or staging areas.

The buildings are used to collect, categorize and sort, store, manifest, and ship wastes originating in various areas of the Y-12 Plant.

Each laboratory waste received at these buildings must be accompanied by a detailed description provided by the generator. The DOT hazard class is determined for each chemical prior to receiving it at the buildings, and the waste will then be directed to the appropriate staging storage areas. See Section $\mathrm{C}-1$ for a discussion of waste identification procedures. The waste descriptions and laboratory analysis results are used by Waste Management to determine which wastes may be packed in the lab pack quantity drum.

It is the responsibility of the generator to insure that incompatible wastes are not initially placed in the same container. Adequate aisle space is maintained on each side of the container storage to allow access for inspection. Containers are opened only when additional waste is added or samples are taken, and they are closed immediately afterward. The unit operators are trained in the proper handling of hazardous waste, including the importance of not adding an incompatible waste to a partially filled container. Wastes are mixed only if it is known from experience that they are compatible and after the contents of each drum are characterized. Hazardous wastes will not be placed into any unwashed container that previously held an incompatible waste or material. The use of properly washed containers, appropriate information, identification of the waste, and knowledge of waste compatibilities will prevent an operator from placing waste into a container that previously held an incompatible waste. Wastes are characterized in accordance with the waste analysis plan in Section C, Waste Characteristics. 


\section{F-5e Management of Ignitable or Reactive Wastes in Tanks}

Not applicable. The units in this permit application are container storage areas; therefore, the requirements of this section do not apply.

\section{F-5f Incompatible Wastes in Tanks}

Not applicable. The units in this permit application are container storage areas; therefore, the requirements of this section do not apply.

\section{F-5g Ignitable or Reactive Wastes in Waste Piles}

Not applicable. The units covered in this permit application are not waste piles; therefore, the requirements for this section do not apply.

\section{F-5h Incompatible Wastes in Waste Piles}

Not applicable. The units covered in this permit application are not waste piles; therefore, the requirements for this section do not apply.

\section{F-5i Ignitable or Reactive Wastes in Surface Impoundments}

Not applicable. The units covered in this permit application are not surface impoundments; therefore, the requirements for this section do not apply.

\section{F-5j Incompatible Wastes in Surface Impoundments}

Not applicable. The units covered in this permit application are not surface impoundments; therefore, the requirements for this section do not apply.

\section{F-5k Ignitable or Reactive Wastes in Landfills}

Not applicable. The units covered in this permit application are not hazardous waste landfills; therefore, the requirements for this section do not apply.

\section{F-51 Incompatible Wastes in Landfills}

Not applicable. The units covered in this permit application are not hazardous waste landfills; therefore, the requirements for this section do not apply.

\section{F-5m Ignitable or Reactive Wastes in Land Treatment}

Not applicable. The units covered in this permit application are not land treatment units; therefore, the requirements for this section do not apply. 


\section{F-5n Incompatible Wastes in Land Treatment}

Not applicable. The units covered in this permit application are not land treatment units; therefore, the requirements for this section do not apply. 


\title{
Resource Conservation and Recovery Act (RCRA) General Contingency Plan for Hazardous Waste Treatment, Storage, and Disposal Units at the Oak Ridge Y-12 Plant
}

Environmental Management Department

Health, Safety, Environment, and Accountability Organization

August 1994

\author{
Prepared by the \\ Oak Ridge Y-12 Plant \\ Oak Ridge, Tennessee 37831 \\ Managed by \\ MARTIN MARIETTA ENERGY SYSTEMS, INC. \\ for the \\ U.S. DEPARTMENT OF ENERGY \\ under contract DE-AC05-84OR21400
}




\section{DISCLAIMER}

This report was prepared as an account of work sponsored by an agency of the United States Government. Neither the United States Government nor any agency thereof, nor any of their employees, makes any warranty, express or implied, or assumes any legal liability or responsibility for the accuracy, completeness, or usefulness of any information, apparatus, product, or process disclosed, or represents that its use would not infringe privately owned rights. Reference herein to any specific commercial product, process, or service by trade name, trademark, manufacturer, or otherwise, does not necessarily constitute or imply its endorsement, recommendation, or favoring by the United States Government or any agency thereof. The views and opinions of authors expressed herein do not necessarily state or reflect those of the United States Government or any agency thereof. 


\title{
Resource Conservation and Recovery Act (RCRA) Contingency Plan for Hazardous Waste Treatment, Storage, and Disposal Units at the Oak Ridge Y-12 Plant
}

\author{
Environmental Management Department \\ Health, Safety, Environment, and Accountability Organization
}

\author{
Prepared by the \\ Oak Ridge Y-12 Plant \\ Oak Ridge, Tennessee 37831 \\ Managed by \\ MARTIN MARIETTA ENERGY SYSTEMS, INC. \\ for the \\ U.S. DEPARTMENT OF ENERGY \\ under contract DE-AC05-84OR21400
}




\section{RESOURCE CONSERVATION AND RECOVERY ACT (RCRA) \\ GENERAL CONTINGENCY PLAN FOR \\ HAZARDOUS WASTE TREATMENT, STORAGE, AND DISPOSAL UNITS \\ AT THE OAK RIDGE Y-12 PLANT}

\section{GENERAL FACILITY DESCRIPTION}

The Oak Ridge Y-12 Plant was built by the U.S. Army Corps of Engineers in 1943 as part of the Manhattan Project and given the original mission of separating the fissionable isotope of uranium by the electromagnetic process. After World War II, the electromagnetic process was discontinued in favor of the more economical gaseous diffusion process. In recent years, the Y-12 Plant staff has developed this facility into a highly sophisticated manufacturing and developmental engineering organization.

The U.S. Department of Energy (DOE) owns and operates the Y-12 Plant. Martin Marietta Energy Systems, Inc., co-operates and manages the Y-12 Plant. Since 1984, the facility has been managed by Martin Marietta Energy Systems, Inc. personnel, under a prime contract with the U.S. DOE. The contract is administered by personnel at the DOE, Oak Ridge Operations.

The Y-12 Plant occupies approximately 800 acres in Anderson County, Tennessee, and is located southwest of the city of Oak Ridge. The site employs approximately 4,000 people, including employees of the Oak Ridge National Laboratory assigned to the Y-12 Plant. Two surface streams, East Fork Poplar Creek and Bear Creek, border the facility on the south, east, and southwest sides of the plant. There is access to the Y-12 Plant, controlled on Bear Creek Road, on the north side of the facility, indirect access from Scarboro Road on the east side of the facility, and indirect access to the facility on the south side via Bethel Valley Road. A controlled access road from Bethel Valley Road by way of Mt. Vernon Road is located on the southwest side of the site.

It is the mission of the Y-12 Plant to serve as a key manufacturing technology center for the development and demonstration of unique materials, components, and services of importance to the DOE and the nation. This is accomplished through the reclamation and storage of nuclear materials, manufacture of nuclear materials, manufacture of components for the defense capabilities of the nation, support to national security, programs, and services provided to other customers as approved by DOE.

\section{GENERAL INFORMATION}

The Y-12 RCRA Contingency Plan will be continually reviewed and revised if any of the following occur: the facility permit is revised, the plan is inadequate in an emergency, the procedures herein can be improved, the operations of the facility change in a way that alters the 
plan, the emergency coordinator changes, or the emergency equipment list changes. Copies of the Y-12 Emergency Management Plan are available at the Plant Shift Superintendent's Office and the Emergency Management Office. This document serves to supplement the Y-12 Emergency Management Plan to be appropriate for all RCRA hazardous waste treatment, storage, or disposal units. The 90-day accumulation areas at the Y-12 Plant have a separate contingency supplement as required by RCRA and are separate from this supplement.

The facility name, address, identification number, and owner/operator name are provided below:

\author{
U.S. Department of Energy Oak Ridge Y-12 Plant \\ Bear Creek Road \\ Post Office Box 2001 \\ Oak Ridge, Tennessee 37831-8555 \\ EPA ID TN3 89-009-0001 \\ Owned and operated by U.S. Department of Energy \\ Managed and co-operated by Martin Marietta Energy Systems, Inc.
}

The overall layout of the Y-12 Plant and the location of RCRA units are shown in Figure 1, "Y-12 Plant RCRA Waste Unit Locations." Figure 2, "Y-12 Plant Emergency Facilities Directory," shows the locations of assembly stations, boundaries, and access controls to the plant. Figure 3, "Y-12 Plant Bear Creek Burial Ground Waste Unit Map," shows the units located at the west end of the plant, Gamewell alarm box locations, boundaries, and access controls to these areas. Figure 4, "Y-12 Plant Evacuation Routes", shows a typical evacuation route that could be used to evacuate the Y-12 Plant in the event of an emergency. The Plant Emergency Director (PED) will ultimately determine and direct all personnel to the appropriate evacuation routes.

\title{
EMERGENCY COORDINATORS
}

The emergency coordinator at the Y-12 Plant is the PED. The Y-12 Plant has several Plant Shift Superintendents (PSS) who share the responsibilities of the PED. At least one PSS is on duty 24 hours per day, every day of the year, and can be reached at (615) 574-7172 at the Emergency Operations Center (EOC) in Building 9706-2. The alternate EOC is located in Building 9709 and the phones are transferred if the operations are being conducted at this building. The PSS on duty is responsible for providing continuous plantwide emergency direction as the PED. If the PED is incapacitated during an emergency, the Site Security Commander on duty is his alternate until another PSS can report to the scene. The PSS, or alternate, has access to names, telephone numbers, and addresses of all emergency personnel and will determine who must be contacted to provide emergency activity support. 
The duties of the PED as the Emergency Coordinator include:

- Receiving notice that an incident has occurred;

- Evaluating the threat;

- Activating internal alarm systems to notify or evacuate personnel, if appropriate;

- Proceeding immediately to obtain information concerning released materials and initiating appropriate activities for characterizing and abating the release;

- Ensuring that necessary on-site notifications are made;

- Performing an assessment of the potential for off-site effects upon the public health and environment and notifying DOE-Oak Ridge EOC of the same;

- Initiating and directing a plan of action;

- Mobilizing sufficient forces, including technical assistance, to respond to the emergency at hand;

- Directing the overall effort to respond to plant emergencies in such a way as to ensure that all emergency groups, both local and plantwide function as a team.

- Delegating authority in any capacity necessary if the need arises during an emergency;

- Authorizing all rescue efforts requiring any employee experiencing illness or injury;

- Seeing that off-site medical facilities are notified immediately when a seriously ill or injured patient is en route, and provide the nature of the injury or illness;

- Ensuring that a medical department staff member, a supervisor, or someone knowledgeable as to the circumstances or acquainted with the details of any serious accident or illness accompanies the patient to the emergency room;

- Determining the accessibility of plant areas after an accident and authorizing reentry of evacuated areas; 
- Under special conditions, requesting the designation of a technical group to assist in evaluating the advisability of reentry;

- Terminating emergency status when the threat is entirely gone;

- Authorizing, when applicable, the sounding of the "all clear" signal at the termination of an emergency; and

- Restoring the plant to normal operations.

The names and work numbers of the PSS are provided below:

\begin{tabular}{lcc}
\multicolumn{1}{c}{ Name } & Building Location & Work Phone \\
W. M. Bradley & $9706-2$ & (615) $574-7172$ \\
L. K. Brooks & $9706-2$ & $(615) 574-7172$ \\
J. D. Chapman & $9706-2$ & $(615) 574-7172$ \\
E. Manis & $9706-2$ & $(615) 574-7172$ \\
P. C. Norris & $9706-2$ & $(615) 574-7172$ \\
C. L. Beeler & $9706-2$ & $(615) 574-7172$ \\
G. L. Calvert & $9706-2$ & $(615) 574-7172$
\end{tabular}

Emergency resource books containing lists of emergency response telephone numbers (Emergency Response Organization personnel, facilities, off-site agencies, outside support organizations, etc.) are readily available to the PED in the EOC and alternate EOC. Telephone listings are revised as changes occur. In addition, a quarterly review is conducted by the Emergency Preparedness Operations Department Manager. The PED has the authority to commit the necessary resources to implement the contingency plan. 


\section{IMPLEMENTATION}

The decision to implement this contingency plan, as part of the Emergency Management Plan, depends upon whether an imminent or actual incident could threaten human health or the environment.

The contingency plan will be implemented by the PED in the following situations:

- A fire and/or explosion occurs, such that:

- The potential for human injury exists;

- Toxic fumes that could endanger human health or the environment are released;

- The fire could spread on site or off site and possibly ignite other flammable materials or cause heat-induced explosions;

- The use of water and/or chemical fire suppressants could result in contaminated runoff that could endanger human health or the environment; and/or

- An imminent danger exists that an explosion could ignite other hazardous wastes at the facility and possibly result in the release of toxic materials.

- A spill or release of a hazardous material occurs such that:

- The spill could result in release of flammable liquids or vapors, thus causing a fire or gas explosion hazard;

- The spill could cause the release of toxic liquids or fumes that could endanger human health or the environment; and/or

- The spill cannot be contained on site, resulting in off-site soil contamination and/or ground or surface water pollution that could endanger human health or the environment.

Many ways of discovering a spill or release of chemicals are possible. These include: routine and scheduled inspections of process equipment and material storage areas; unusual or strong chemical odors which may indicate a leak; and instrumentation such as level alarms, automatic sump pumps, and $\mathrm{pH}$ meters which may also reveal chemical spills or system malfunctions.

\section{CONTROL PROCEDURES - INCIDENT COMMANDER}

The incident commander is defined as the person assuming command and control of emergency response at the scene of the incident. The incident commander will be the operations supervisor on duty for a specific unit or, in the absence of a supervisor, the first arriving emergency response officer designated by the PED. The incident commander will be responsible for the following:

- Initial assessment of the incident scene to the PED;

- Establishing control and setting up the command post for emergency response; 
- Initial evaluation of the magnitude of the problem;

- Evacuation of personnel from immediate danger;

- Arranging for assembly, organization, and briefing of emergency response personnel who have been summoned;

- Providing updated information on conditions, progress of response, and additional manpower or equipment needs to the PED;

- Directing operational changes needed (e.g., shutting off process flows);

- Implementing applicable prearranged plans and procedures; and

- Continuing to provide incident control until relieved by an alternate incident commander.

The following actions will be taken in areas affected by a fire or explosion:

1. Work in the affected areas will be shut down immediately.

2. Feedlines and additional equipment will be shut down, as necessary and practical.

3. The PED will be contacted.

4. The area will be cleared of all personnel not actively involved in fighting the fire. These persons are to report to the designated assembly points for accountability.

5. All injured persons will be removed, and medical treatment will be administered by Medical Department personnel with outside assistance, as required.

\section{EMERGENCY RESPONSE PROCEDURES - EMERGENCY COORDINATOR}

The PED is responsible for the overall direction of emergency response efforts as follows:

- Directs emergency service units and local emergency squads.

- Ensures that the incident commander at the scene of the emergency, evaluates:

- Radiation and general safety situations as they affect the immediate and adjacent areas,

- Need for interrupting utility services such as process water, ventilation, oxygen, natural gas, and electricity, and 
- Need for operational changes.

- Considers the need for and arranges for any large-scale alert, evacuation, general alert, invocation of mutual assistance agreements, and procurement of additional emergency personnel or emergency equipment.

- Keeps Y-12 Plant management and appropriate staff groups informed.

- Determines when the emergency is over, and orders the "all clear" signal.

The Emergency Management Department staff is responsible for:

- Y-12 Plant-wide emergency planning.

- Updating the Emergency Management Plan.

- Planning for practice exercises.

- Coordinating the organization and training of emergency service units and local emergency organizations.

- Ensuring that plans are in place for receiving and evaluating emergencies.

- Ensuring that plans are in place for activating internal alarm systems to alert/evacuate personnel.

- Planning coordination for the emergency response team; determine if outside assistance is required.

- Ensuring that plans are in place to report incidents to personnel at the DOE, Oak Ridge Operations in accordance with DOE Order 5000.3A "Occurrence and Processing of Operations Information."

\section{Notification}

The employee discovering a potential emergency incident will notify his immediate supervisor and/or the PED. The PED will immediately activate the internal alarm system to notify or evacuate personnel, if appropriate. The PED will also notify the Plant Manager, the Production Manager, the Environmental Coordinator, and Organization Managers of the operations involved. 
In the event that outside assistance is required, the PED will notify appropriate state and/or emergency response agencies.

\section{Identification of Hazardous Materials}

The incident commander will immediately attempt to identify the character, exact source, amount, and aerial extent of the material involved in the fire or release. The initial identification method will be by visual analysis of the material and location of the release. Plant records, including inventories and process and waste log sheets, are available at the operating department offices of the RCRA units to aid in estimating the composition and quantity of released material. In the event of a spill, a sample of the spilled material is taken if the material enters a storm drain, there is some question as to the identity of the material, or the material is suspected to contain polychlorinated biphenyls (PCBs). The Health, Safety, Environment, and Accountability Organization staff will sample to verify hazardous material identification, determine boundaries of contaminated areas and contaminant concentrations, and verify proper cleanup after cleanup activities are completed.

Information such as storm sewer locations and topographic information is available to support the PED in the process of identifying potential flow/contamination paths and determine appropriate control actions.

\section{Hazard Assessment}

Assessment of possible hazards to human health or the environment will be made using the following methods:

1. Process knowledge (i.e., knowledge of the nature of waste materials released);

2. Review of Material Safety Data Sheets, if available;

3. Chemical analysis/monitoring data;

4. Results of modeling for releases to air, surface water, or groundwater; and

5. Specific health-based and environmental criteria or limits which may be exceeded.

Based on the hazard assessment, evacuation of the immediate unit area, entire facility, or local areas outside the facility may be necessary.

\section{Off-Site Notification/Evacuation}

The Y-12 Emergency Management Plan describes the methods used for notification of Y-12 emergency response personnel and appropriate federal, state, and local emergency response centers. Individuals or groups that may be notified include, but are not limited to, the following: 
- DOE Oak Ridge Operations EOC,

- DOE Headquarters EOC (through the Oak Ridge Operations EOC voice bridge),

- Tennessee Emergency Management Agency,

- National Response Center,

- Local Emergency Planning Councils,

- Affected county notification points,

- City of Oak Ridge (Anderson County),

- Regional U.S. Environmental Protection Agency, and

- Other agencies as required by regulatory guidance.

Evacuation of nonessential personnel is ordered by the PED if it is determined that a threat to the safety of plant personnel exists. Evacuation routes will be determined by the PED; however typical evacuation routes are shown in Figure 4.

\section{Prevention of Recurrence or Spread}

After incident mitigation, a recovery manager will be appointed to return the incident scene to preincident conditions and analyze the root cause of the incident.

\section{Storage and Treatment of Released Material}

Any hazardous materials that results from a release, fire, or explosion at the Y-12 Plant will be contained, removed, and placed in 55-gallon drums (or smaller containers if appropriate).

Leaking or damaged containers will be placed in 85-gallon overpack drums so they can be stored until treatment or disposal arrangements are finalized.

Contaminated absorbent materials, protective clothing, and other disposable material used in remediation of the emergency and subsequent decontamination activities will be placed in 55-gallon drums and stored at a RCRA storage unit pending treatment or disposal. These items will be handled with the same degree of caution as the wastes themselves so that public health and the environment are not further threatened.

Immediately after an emergency, the emergency coordinator will make arrangements for treatment, storage, or disposal of recovered waste, contaminated soil, surface water, or any other contaminated material. Emergency and spill response equipment available for cleanup, storage, and treatment are identified in the Y-12 Emergency Management Plan.

\section{Incompatible Waste}

In order to prevent reactions caused by proximity of incompatible substances, wastes which have been spilled or released must be segregated from other wastes or materials which are incompatible. It is a duty of the Spill Response Coordinator to ensure that wastes which may be 
incompatible with the released material are not treated, stored, or disposed of in the vicinity of the spill or fire until cleanup procedures are completed.

Incompatible wastes are unlikely to be treated, stored, or located in the affected areas until cleanup is completed because of the waste segregation practices used at the facility. If possible, no additional wastes will be stored in the affected area until the cleanup is completed. If waste storage there is necessary, wastes will be placed only in those areas where no incompatible wastes are present.

\section{Postemergency Equipment Maintenance}

All emergency response elements will ensure that team equipment is properly decontaminated, supplies are restocked, and the team is returned to preemergency readiness.

\section{Container Spills and Leakage}

In the event of a hazardous material spill or release, the following general procedures will be used for rapid and safe response and control of the situation. Spills or releases and impending spills or releases discovered during routine inspections will be handled in the same manner as described below for spill and release emergencies. These are general guidelines, and circumstances may dictate some alterations to these procedures.

If an employee discovers a chemical spill or process upset resulting in a hazardous material release, he or she will immediately report it to the area supervisor. The area supervisor or the employee will contact the PED. When contacted, the PED will obtain information pertaining to the following:

1. The material spilled or released,

2. Location and source of the release or spillage of hazardous material,

3. An estimate of the quantity released and the rate at which it is being released,

4. The direction in which the spill, vapor, or smoke release is heading,

5. Any injuries involved, and

6. Fire and/or explosion or possibility of these events.

This information will help the PED to assess the magnitude and potential seriousness of the spill or release. The PED will contact and deploy the necessary in-plant personnel. If additional assistance is required, the PED will also contact the other Oak Ridge plants that have agreed to provide assistance and the agencies discussed in the Coordination Agreements section of this plan.

The initial response to any emergency will be to protect human health and safety, and then the 
environment. Identification, containment, treatment, and disposal assessment will be the secondary responses.

Medical assistance for injured persons will be obtained from the Y-12. Health Services staff.

Cleanup personnel summoned by the PED will don protective clothing and equipment, as specified by the Health, Safety, Environment, and Accountability Organization staff. If a flammable waste is involved, all ignition sources will be removed, and spark and explosion-proof equipment and clothing will be used for containment and cleanup activities. If possible, cleanup personnel will try to stop the leak. Special materials, such as tank patch kits, will be kept on hand for temporary repairs. All surrounding materials that could be reactive with the waste materials will be removed. The major components of the waste will be determined.

Absorbent pads, booms, earth, sandbags, sand, and other inert materials will be used to contain, divert, and clean up a spill if it has not been contained by a dike or sump. Sewer plugs are available, if required, to isolate a spill. Spills contained within a dike or sump may be pumped back into the appropriate storage tank or drum, if it is structurally sound. All containment and cleanup materials will be placed in drums for proper disposal. Some items, such as absorbent rags or booms, may have to be cut up. All recovered liquid wastes and contaminated soil that cannot be returned to their original storage tanks or containers will be placed in drums for removal to an approved storage or disposal site.

Most tank and container spills and leaks are contained within the dikes and sumps provided in the tank and container areas. Small spills occurring in a diked area are directed to the sump provided in that area. Immediately after the spill is detected, the Waste Management Organization staff will be summoned to remove any standing liquids (as described above) and arrange to have the spilled material taken to a unit approved to handle that particular waste. If necessary, a portable sump pump will be used to pump the diluted waste material into 55-gallon drums. The transfer of the spilled material will be performed within 24 hours or at the earliest practical time if it is demonstrated that the material cannot be transferred within 24 hours.

If, for some reason, a chemical spill is not contained within a dike or sump area, an appropriately sized area of isolation will be established around the spill. The size of the area will generally depend on the size of the spill and the materials involved. An area at least 50 feet in all directions will be isolated. For large spills, an area at least 100 feet in all directions will be isolated. When any spill occurs, only those persons involved in overseeing or performing emergency operations will be allowed within the designated hazard area. If possible, the area will be roped or otherwise blocked off. All persons not actively involved in managing the spill will be kept upwind. 
If the PED determines that $\mathrm{Y}-12$ and the other DOE plants are unable to handle the emergency, then local, state, and federal authorities will be notified of the situation. When necessary, evacuation of all potentially affected plant areas will begin as soon as possible.

All emergency equipment used for spill management must be cleaned by the responsible personnel so that it is fit for use prior to resumption of plant operations in the affected areas.

\section{Tank Spills and Leakage}

In the event of a hazardous material spill or release, the procedures described for container spills and leakage apply for tank releases.

\section{EMERGENCY EQUIPMENT}

A listing of typical emergency and spill response equipment for the $\mathrm{Y}-12$ Plant is listed in Appendix B. The specific emergency and spill response equipment is provided in the Y-12 Emergency Management Plan. In addition, emergency equipment is maintained at the units in this plan for minor releases which include, but is not limited to, absorbent material, fire extinguishers, shovels, shoe scuffs, gloves, eye protection, and protective clothing. The inspection lists and frequency for inspection of the spill response equipment at the units are presented in the Y-12 Emergency Management Plan.

\section{COORDINATION AGREEMENTS}

The Y-12 Emergency Management Plan details all coordination agreements currently held with local agencies. These agreements provide for emergency assistance to other participants in the event of major fires, explosions, natural disasters accidents involving hazardous/radiological materials, and situations that could endanger life, public safety, or the environment or that have an extensive area impact. This agreement includes the K-25 Site, the Y-12 Plant, and ORNL. Examples of these agreements are provided in Appendix C. A copy of this plan has been provided to all mutual aid organizations. Designated emergency coordinators will commit the necessary resources to implement the contingency plan. The PED will request assistance, when necessary, from other DOE sites. Each plant will have authority to provide emergency equipment and personnel upon request. The Emergency Directors' telephone numbers are:

$\begin{array}{ll}\text { Y-12 Plant } & 615-574-7172 \\ \text { K-25 Site } & 615-574-3282 \\ \text { ORNL } & 615-574-6606 \\ \text { DOE Security } & 615-576-1004\end{array}$




\section{EVACUATION PLAN}

All emergencies at the Y-12 Plant warrant prompt and deliberate action. Criteria for evacuation have been established. The PED is responsible for determining whether evacuation is necessary. The Y-12 Emergency Management Plan contains details of this criteria. If evacuation of the Y-12 Plant is necessary evacuation routes that would typically be used are illustrated in Figure 4.

\section{REQUIRED REPORTS}

The PED will note in the operating record the time, date, and details of any incident which required implementation of the Contingency Plan. Internal reports will be filed as required by DOE and Martin Marietta Energy Systems, Inc., personnel.

Within 15 days after the incident, personnel from the Y-12 Plant will submit a written report on the incident which required implementation of the Contingency Plan to the DOE staff for review and transmittal to the Commissioner of the Tennessee Department of Environment and Conservation, as required by Tennessee Rule 1200-1-11-.06(5)(c). The report will include:

- Name, address, and telephone number of the owner or operator;

- Name, address, and telephone number of the facility;

- Date, time, and type of incident (e.g., fire, explosion);

- Name and quantity of material(s) involved;

- The extent of injuries, if any;

- An assessment of actual or potential hazards to public health or the environment, where this is applicable; and

- Estimated quantity and disposition of recovered material that resulted from the incident. 


\begin{abstract}
APPENDIX A
UNIT-SPECIFIC EMERGENCY and WASTE DESCRIPTIONS

This section summarizes unit-specific contingency and waste description information for the treatment, storage, and disposal units below.

\section{Cyanide Treatment Unit}

The Cyanide Treatment Unit is located in Building 9201-5N. The nearest Gamewell box is located on the south wall outside of Building 9201-5N. This Gamewell box is connected to the existing plant Gamewell Fire Alarm System and Plant Monitoring System. A telephone is available in the room where the unit is located. An eyewash and safety shower station is also available in this room. Two-way radios are available to communicate with the PED office, if emergency assistance is necessary.
\end{abstract}

The Cyanide Treatment Unit treats cyanide wastes that have been generated in various plant operations.

\title{
Kerr Hollow Quarry Treatment Unit
}

The Kerr Hollow Quarry Treatment Unit is located 0.4 miles west of the intersection of Scarboro Road and Bethel Valley Road on the north side of Bethel Valley Road. A public address system is installed at this unit, along with closed circuit television. Two-way radios are used, and a telephone is available in the guard shack for communication with the PED office, if emergency assistance is required.

This unit no longer receives hazardous waste. Closure of this unit is complete and approval is pending.

\section{Garage Underground Tanks}

The Garage Underground Tanks are located near Building 9737. A Gamewell box is located nearby at the service station and connected to the existing plant Gamewell Fire Alarm System and Plant Monitoring System. Two-way radios are used by personnel at this site to provide communication with the PED office, if emergency assistance is needed. A phone is available in Building 9712 East End Garage, as well as an eyewash/safety shower station.

This unit no longer receives hazardous waste. It is currently undergoing closure.

\section{Walk-In Pits}

The Walk-In Pits are located north of Disposal Area Remedial Action (DARA) Solids Storage 
Unit, in the Bear Creek Burial Grounds. The nearest available phone, Gamewell box, eyewash and safety shower are located at the DARA Liquid Storage and Treatment Unit. The Gamewell box is connected to the existing plant Gamewell Fire Alarm System and Plant Monitoring System. Two-way radios are used for communication with the PED office, if emergency assistance is needed.

Closure of this unit is complete and approval is pending.

\section{Interim Drum Yard}

Interim Drum Yard is located near Building 9720-32. The nearest available Gamewell box is located on the east end of Building 9720-32. This Gamewell box is connected to the existing plant Gamewell Fire Alarm System and the Plant Monitoring System. A portable eyewash and safety shower are used by personnel at this unit. Two-way radios are used for communication with the PED if emergency assistance is needed, and a phone is also available nearby in Building 9401-5.

This unit no longer receives hazardous waste and the closure plan has been submitted for this unit. Approval and closure activities are pending.

\section{Building 9720-9, Storage Unit}

Building $9720-9$ is located on Third Street. Two Gamewell boxes are located at the east and west sides of the building and connected to the existing plant Gamewell Fire Alarm System and the Plant Monitoring System. Telephones and two-way radios are also used by personnel to provide communication with the PED office, if emergency assistance is needed. Two eyewash/safety showers are provided and located at the west and south sides of the building.

This unit provides storage for hazardous, nonhazardous, and mixed waste. Waste is stored at this unit until waste analysis and appropriate treatment or disposal can be arranged. All classes of RCRA wastes, except for K-listed wastes, and hazardous wastes from specific sources (40 CFR Part 261.32 and Tennessee Rule 1200-1-11.02(4)) are stored in this unit.

\section{RCRA and Mixed Waste Storage and Staging Unit, Building 9720-31}

Building $9720-31$ is located on West Third Street. Two Gamewell boxes are located on the east and west side of the building and connected to the existing plant Gamewell Fire Alarm System and the Plant Monitoring System. Telephones and two-way radios are also used by personnel to provide communication with the PED offices, if emergency assistance is needed.

This unit is used to store solids, liquids, and sludge wastes, which typically are hazardous, nonhazardous, or mixed waste. It is a one-story structure constructed of light-weight, concrete 
block, masonry walls and partitions. The building is partitioned into fifteen rooms: one supply room, seven staging rooms, and seven storage rooms. Normally, the largest containers in any of the staging or storage rooms are 55-gallon drums, however, 85-gallon overpack containers may be used to store waste. Waste stored in the staging and storage rooms may be in Department of Transportation-specification containers or the original product containers.

\section{Building 9811-1 RCRA Tank Storage Unit (OD-7)}

Building 9811-1 RCRA Tank Storage Unit is located at the intersection of West Second Street and $\mathrm{K}$ Road. It is served by an auxiliary fire alarm pull box which is inside the south side of Building 9811-1. Additional alarm boxes are located at Building 9720-16, and at the intersection of Second Street and K Road which is southwest of OD-7. These boxes are connected to the existing plant Gamewell Fire Alarm System and the Plant Monitoring System. Two fire hydrants are located near this unit. One is approximately 20 feet north of the RCRA Storage Unit, and the second hydrant is located approximately 75 feet southwest. Telephones and two-way radios are used by personnel to provide communication with the PED office, if emergency assistance is needed. A telephone is also located in the OD-7 operator trailer for communication with emergency personnel. A safety shower/eyewash assembly is planned for installation at a future date at the drum loading/unloading area and the transfer station as part of an OD-7 upgrade project.

This unit is designated as the primary storage unit for nonignitable and nonreactive, mixed waste oils and solvents. Contaminated oils, nonchlorinated solvents, some toxicity characteristic wastes, and used oil may also be accepted at the unit. The storage tank area of the unit consists of a 51$x$ 58-foot, concrete, diked area. Positioned within the diked area are four, 30,000-gallon tanks and one, 10,000-gallon tank. Two additional 10,000-gallon tanks will be installed at a future date.

\section{Building 9811-1 - RCRA Container Storage Unit (OD-8)}

Building 9811-1 is located at the intersection of West Second Street and K Road. A Gamewell box is located on the south side of the building (inside) and connected to the existing plant Gamewell Fire Alarm System and the Plant Monitoring System. A safety shower/eyewash is located at the north side of the building.

This unit is used primarily as a storage area for containerized liquid waste until the waste has been characterized to allow transfer to other treatment, storage, or disposal units. Contaminated liquids with a concentration of greater than $50 \mathrm{ppm}$ PCBs will not be stored at this unit.

\section{Waste Oil/Solvent Storage Unit (OD-9)}

The Waste Oil/Solvent Storage Unit is located on Old Bear Creek Road, and served by an auxiliary fire alarm pull box. The Gamewell box is connected to the existing plant Gamewell Fire 
Alarm System and the Plant Monitoring System. Two fire hydrants are available for use and are freeze-proof. One hydrant is located along the site access road approximately 60 feet east of the truck entrance to the building. The second hydrant is on the north side of Old Bear Creek Road, near the site egress road, approximately 100 feet southwest of the facility truck exit area.

Telephones and two-way radios are used by personnel to provide communication with the PED office, if emergency assistance is needed. Two safety shower/eyewash assemblies, both of which are freeze-proof, are located at the northeast corner of the tank area (in the truck loading pad adjacent to the drum storage area) and on the floor of the containment structure. Potable water is supplied to both units and is identified by green lights installed above each unit. The eye/face units are push bar operated with stay-open valves.

This unit typically receives and stores nonignitable and nonreactive mixed waste oil/solvents that may contain water, be contaminated with PCBs greater than $50 \mathrm{ppm}$, and contain chlorinated organic solvents. This unit may also store used oil. The liquid wastes are stored here in tanks and drums until sufficient volume is accumulated for transportation to an outside facility for recovery or disposal.

\section{Liquid Organic Solvent Storage Unit (OD-10)}

The Liquid Organic Solvent Storage Unit is located in the Bear Creek Burial Grounds, and served by an auxiliary fire alarm pull box which is located approximately 40 feet south of the unit. An additional Gamewell box is accessible at the intersection of Bear Creek Road and the access road to OD-10. This Gamewell box is connected to the existing plant Gamewell Fire Alarm System and Plant Monitoring System. A freeze-proof fire hydrant is located approximately 200 feet south of the unit. Two-way radios provide communication between the unit and the PED office, if emergency assistance is necessary. Three safety shower/eyewash assemblies are provided at OD-10, which includes two located in the staging area (north and south side) and the third located in the tank area. Potable water is supplied to these assemblies, which are push bar operated with stay-open valves. Each unit is identified by a green light installed above each assembly.

This unit receives and stores liquid organic wastes generated in the Y-12 Plant. These wastes typically include waste oil and combustible and flammable waste liquids that may be defined as mixed waste or used oil. The liquids received at this unit are pumped into the tanks for storage until sufficient quantity is accumulated for final disposal or recovery.

\section{Building 9409-5 Storage Unit}

The Building 9409-5 Storage Unit is located on Third Street. The nearest Gamewell box is located in Building 9409-2. This Gamewell box is connected to the existing plant Gamewell Fire Alarm System and Plant Monitoring System. No phone is available, and this unit is no longer in 
service. Two-way radios are used to communicate with the PED office, if emergency assistance is needed.

This unit no longer receives hazardous waste. It is currently undergoing closure.

\section{East Chestnut Ridge Waste Pile}

The East Chestnut Ridge Waste Pile is located on South Patrol Road. Two-way radios are used to communicate with the PED office, if emergency assistance is required. The nearest Gamewell box is located southwest of the unit across the street from the Containerized Waste Storage Area. This Gamewell box is connected to the existing plant Gamewell Fire Alarm System and Plant Monitoring System.

This waste pile is used for the storage of soils and spoils contaminated with hazardous and lowlevel radioactive materials, asbestos, and roofing materials from the closure of RCRA sites at the Y-12 Plant. Additional contaminated soils may be moved to the East Chestnut Ridge Waste Pile if excavation activities continue at the Y-12 Plant.

\section{Containerized Waste Storage Area (CWSA)}

The CWSA is located on South Patrol Road. A Gamewell box is located south, directly across the street from the CWSA, and is connected to the existing plant Gamewell Fire Alarm System and the Plant Monitoring System. Two-way radios are also used to provide communication with the PED office, if emergency assistance is needed. A portable safety shower/eyewash is provided during operations.

The CWSA consists of three concrete pads measuring 170 feet long and 50 feet wide. The central and eastern concrete pads are covered by open-sided dome tents and store hazardous, nonhazardous, or mixed wastes. The western concrete pad is not covered, and no wastes are stored there. Each pad has a one-foot impermeable dike surrounding it to contain spills. The pads and dikes are sloped toward a 60-gallon sump located on the southeast corner of the pads to catch spilled material and manage rainwater.

\section{Classified Container Storage Unit, Building 9720-25}

Building 9720-25 is located on M Street. Two Gamewell boxes are located inside the building and connected to the existing plant Gamewell Fire Alarm System and the Plant Monitoring System. Telephones and two-way radios are also used by personnel to provide communication with the PED office, if emergency assistance is needed.

Building 9720-25 is a storage unit designed for storage of classified wastes generated at the Y-12 Plant. The wastes include materials, fabricated parts, and containers which have been 
security classified to prevent dissemination of potentially vital information. Storage in one part of this unit of classified waste, contaminated with hazardous constituents, is necessary due to present uncertainties as to final modes of treatment and/or disposal of classified and/or hazardous waste materials. The stored materials include hazardous and mixed wastes.

\section{Oil Land Farm Soils Containment Pad}

The Oil Land Farm Soils Containment Pad is located west of the main plant area on Bear Creek Road. A telephone is available nearby in the sampling trailer, or two-way radios are used to communicate with the PED office, if emergency assistance is needed. The nearest eyewash/safety shower station is located at the Liquid Organic Solvent Storage Unit, which lies west of this location on Bear Creek Road.

This unit provides storage for contaminated soils and excavation wastes that were generated during RCRA closure of the Oil Land Farm and Oil Retention Ponds at the Y-12 Plant. These soils were contaminated with hazardous, mixed, or radioactive wastes. Contaminants include organics, heavy metals, pesticides, PCBs, and radionuclides. The unit provides interim storage for excavation wastes pending scheduling of the soils for final treatment or disposal.

\section{DARA Solids Storage Unit}

The DARA Solids Storage Unit is located west of the main plant area on Bear Creek Road. A Gamewell box is located near the unloading pad adjacent to the DARA Solids Storage Unit at the DARA Liquid Storage and Treatment Unit. This Gamewell box is connected to the existing plant Gamewell Fire Alarm System and Plant Monitoring System. A telephone is available in the operator's trailer south of the DARA Liquid Storage and Treatment Unit, and two-way radios are also used to communicate with the PED office, if emergency assistance is needed. Eyewash/safety shower stations are available on the unloading pad at DARA Liquid Storage and Treatment Unit.

The DARA Solids Storage Unit provides storage for contaminated sediments and excavation wastes generated during closure of the Oil Retention Ponds. These sediments are contaminated with PCBs and volatile organic compounds. They will be stored in the unit until they can be scheduled for final treatment or disposal.

\section{Interim Reactive Waste Treatment Area (IRWTA) .}

The IRWTA is located west of the main plant area on Bear Creek Road, and served by an auxiliary fire alarm pull box near the trailers at the closed Sanitary Landfill I. Two-way radios are used to provide communication with the PED office, if emergency assistance is needed. Portable eyewash systems are used during operation. In addition, the Y-12 Fire Department staff is at the unit during the treatment process to assist, if needed. 
This interim unit was designed for the treatment of sodium potassium ( $\mathrm{NaK}$ ) generated during maintenance activities at the Y-12 Plant. The unit currently operates in accordance with an open burning permit. The IRWTA is used approximately once per year dependent upon the generation of $\mathrm{NaK}$ wastes. The Fire Department staff are present through the duration of the burn to ensure safe treatment of the $\mathrm{NaK}$, which is water reactive. The Contingency Plan will also be implemented if an emergency arises. The $\mathrm{NaK}$ has a mineral oil layer which takes approximately seven hours to burn. The NaK itself will burn away in approximately 45 minutes. All wastes and equipment are removed from the treatment area when the burn is completed.

\section{Building 9201-4, Container Storage Area}

Building 9201-4 is located on First Street. Gamewell boxes are located within Building 9201-4 and connected to the existing plant Gamewell Fire Alarm System and the Plant Monitoring System. Two-way radios are used, and a telephone is available on the first floor in the southwest corner of the building for communication with the PED office, if emergency assistance is needed.

This unit is located within the exclusion area of the Y-12 Plant and is used to store mercurycontaminated solids such as soil or insulation in containers. Building 9201-4 provides container storage for 55-gallon drums of hazardous and mixed waste resulting from decontamination and decommissioning activities.

\section{Building 9212 Container Storage Area}

The Building 9212 Container Storage Area is located in Building 9212. Telephones are available in nearby supervisors' offices. Eyewash/safety showers are available at each location. Two-way radios are also used to communicate with the PED office, if emergency assistance is needed. Gamewell boxes are located throughout Building 9212. These Gamewell boxes are connected to the existing plant Gamewell Fire Alarm System and Plant Monitoring System.

This area is used to store organic solutions and residues awaiting recovery of enriched uranium. The solutions and residues are mixed wastes.

\section{Building 9206 Container Storage Area}

The Building 9206 Container Storage Area is located in Buildings 9206 and 9720-17. For areas located in Building 9206, Gamewell boxes are located near Rooms 24 and 30. Eyewash and safety shower stations are also located in these rooms. For the area located in Building 9720-17, a Gamewell box and a telephone are located in the corridor outside the area. A telephone is available in Room 18 of Building 9206. Two-way radios are also available in these buildings for communication with the PED office, if emergency assistance is needed. Gamewell boxes are connected to the existing plant Gamewell Fire Alarm System and Plant Monitoring System. 
Building 9206 is the other building at the Y-12 Plant used to store organic solutions and residues awaiting recovery of enriched uranium. The solutions and residues are mixed wastes.

\section{Uranium Treatment Unit}

The Uranium Treatment Unit is located near Building 9767-2. Eyewash/safety shower stations are available at this unit, and the nearest Gamewell box is located 75 feet north of the area on the East Dock between Doors 4 and 5. This Gamewell box is connected to the existing plant Gamewell Fire Alarm System and Plant Monitoring System. Two-way radios are used and a phone is available nearby in Building 9767-2 to communicate with the PED office, if emergency assistance is needed.

The Uranium Treatment Unit is located on the east side of Building 9206, outside and adjacent to the loading dock. The unit consists of two, 300-gallon polytanks located within a diked drum storage area that stores up to eighteen, 55-gallon drums. This unit treats organic solutions which are mixed wastes.

\section{RCRA and PCB Container Storage Area, Building 9720-58}

Building 9720-58 is located on Old Bear Creek Road. Two Gamewell boxes are provided at the east and west sides of Building 9720-58 and connected to the existing plant Gamewell Fire Alarm System and the Plant Monitoring System. Telephones and two-way radios are also used by personnel to provide communication with the PED office, if emergency assistance is needed. A portable eyewash system is provided in the operation trailer adjacent to the unit. A safety shower/eyewash system is also provided at Unit OD-9 that is located directly west of Building 9720-58.

Building 9720-58 is utilized as a storage and staging area for PCB-contaminated equipment (e.g., transformer, capacitors, and electrical switch gear). The area is also used to store RCRA hazardous waste and used as a staging area for other waste materials awaiting off-site shipment. Waste is consolidated at this area until waste analysis and appropriate disposal arrangements can be initiated. 


\section{Building 9720-12 Classified Container Storage Area}

The Building 9720-12 Classified Container Storage Area is located on West Second Street. The nearest Gamewell box is located in the northwest corner of Building 9720-12. This Gamewell box is connected to the existing plant Gamewell Fire Alarm System and Plant Monitoring System. Portable eyewash and safety shower stations are used. Two-way radios are used to communicate with the PED office if emergency assistance is needed.

Building 9720-12 is a storage unit for hazardous, nonhazardous, and mixed waste. Waste is stored at this building until waste analysis and appropriate recycling techniques can be arranged. 


\title{
APPENDIX B
}

\section{EMERGENCY and SPILL RESPONSE EQUIPMENT}

\section{Spill Response Trailer Equipment and Supplies}

The Y-12 Plant Spill Response Trailer, maintained by the Fire Department, is located in the plant and contains supplies and equipment for the response team. The following is an indication of the typical contents of that trailer:

\author{
Respirators \\ Rubber Boots \\ Rain Suits \\ Paper Suits \\ Rubber Gloves \\ Acid-type Gloves \\ Acid Suits \\ Respirator Cartridges (Combination) \\ Flagging \\ Stakes \\ Face Shields (complete) \\ Chemical Splash Goggles \\ Flashlights \\ Extra Batteries \\ Caution Lights (flashing) \\ Shovels, Round Point \\ Shovels, Square Point \\ Sledgehammer \\ Broom (street type) \\ Tape \\ Hose Clamps \\ Plastic Bags (small) \\ Full Face Respirator \\ Absorbent Diapers \\ Sample Bottles \\ Rope \\ Twine \\ Rubber Aprons \\ Ladder (10 ft.) \\ Reflector Vest (orange) \\ Water (for pump) \\ Demineralized Water \\ Pipe Wrench \\ Pliers \\ Pliers, Needle Nose \\ Adjustable Wrench \\ Vise Grips \\ Screwdriver (flat tip) \\ Screwdriver (Phillips head) \\ Channel Lock Pliers \\ Teflon Tape \\ 3" to 2" Pipe Coupling, Stainless \\ Plastic Bags (large) \\ 3" Threaded Coupling \\ Fire Extinguisher
}

Ax 
Building 9720-41

Additional supplies and equipment is located in Building 9720-41. Typical supplies and equipment are listed below:

Pigs

Gas and Air Driven Pumps

Oil Skimmer Booms

Sandbags

Empty Drums (including overpack drums)

Absorbent Diapers

Hoses

Gloves

Ear Plugs

Safety Glasses

Generators

Lighting Systems

Building 9753

Additional supplies and equipment is located in Building 9753. Typical supplies and equipment are listed below:

Leather Gloves

Rubber Gloves

Flashlights

Flashlight Batteries

Chemical Splash Goggles

Shovels

Picks

Boots

Sand Bags

Plastic, 20' x 100' Rolls

Plastic Bags

Barrels

Road Cones

Flagging Strips

Rope

Absorbent Diapers

Paper Suits

Rain Suits 
Fire-Fighting and Medical Response Vehicles:

The Y-12 Plant Fire Department typically operates the following fire-fighting and medical response vehicles:

Fire Pumper No. 1

Fire Pumper No. 2

Fire Pumper Backup

Cardox Fire Fighting Truck

Emergency Response Truck

Fire Chief's Truck

Service Van

Routine Transportation Van

Fire Fighting Equipment Truck

Routine Transportation Truck

Fire Captains' Truck

Medical and Routine Transportation Truck

Ambulance No. 1

Ambulance Backup

Ambulance Backup

Emergency Spill Response Truck 
APPENDIX C

EXAMPLES OF EMERGENCY MUTUAL AID COORDINATION AGREEMENTS 


\section{Department of Energy}

Field Office, Oak Ridge

P.O. Box 2001

Oak Ridge, Tennessee 37831-

January 11,1994

Mr. Frank K. Martin, Director

Energy Systems Protective Services

Martin Marietta Energy Systems, Inc.

P. O. Box 2009

Oak Ridge, TN 37831-8107

Dear Frank,

MUTUAL AID AGREEMENT FOR EMERGENCY AMBULANCE SERVICE, EAST TENNESSEE REGION

Enclosed is a copy of the subject agreement which has been executed by the Oak Ridge Operations Office (ORO) and the Tennessee Department of Health. This is a progressive agreement which enhances the emergency medical response system throughout the sixteen county East Tennessee region.

The ORO Emergency Operations Center (EOC) will serve as the point of contact for the Regional Response Communications Center (RRCC) for requests to ORO for support from Martin Marietta Energy Systems under the agreement. Based upon conversations with your staff, the Y-12 Plant Shift Superintendent (PSS) will serve as the point of contact for the ORO EOC for requests for the Energy Systems Oak Ridge facilities to provide support under the agreement. Likewise, the Y-12 PSS will coordinate any requests from Energy Systems for support for the Oak Ridge facilities and forward such requests to the RRCC through the ORO EOC.

This letter constitutes advance authorization for offsite response of Energy Systems emergency medical resources under the provisions of this Mutual Aid Agreement when such requests are received by the Y-12 PSS from the ORO EOC.

Also enclosed is a copy of the East Tennessee Medical Regional Understanding for the Activation of Mutual Aid. This document should be used as guidance in your preparation of implementing procedures for this agreement. Please ensure that your procedures provide for periodic updates to the ORO EOC concerning any activities being conducted offsite and notification to the ORO EOC of termination of such activities. 
As with other mutual aid agreements, the decision to offer units for offsite response should be predicated upon consideration of facilities' conditions at the time and the maintenance of an appropriate reduced level of response capability for the Oak Ridge facilities.

Questions may be addressed to Bobby Davis of my staff at 6-9725. Your support is appreciated.

Sincerely,

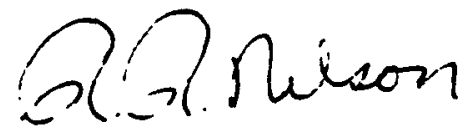

$\widetilde{R}$. R. Nelson

Acting Assistant Manager

for Defense Programs

Enclosures

cc: w/encls.

Ron Hultgren, ER-10

John Rothrock, SE-33

Bill Phelps, DP-82

Karen Edwards, AD-440

Tom Tison, EW-96

Bob Spence, DP-81 
THIS AGREEMENT entered into and executed this 1st day of October 1993 between the U.S. Department of Energy (DOE), Oak Ridge Operations Office and Licensed Ambulance Service (County or Private) to provide for the joint operations of Emergency Ambulance Service within the geographical boundaries of the 16 county East Tennessee Region.

WHEREAS, pursuant to the provisions of Tennessee Code Annotated (T.C.A.) 7-61102, a county is authorized to provide ambulance services as a public service; and,

WHEREAS, T.C.A. 7-61-104(b), authorizes cooperation between cities and counties for the provision of ambulance services and T.C.A. 12-9-101, t. seq., same being the "Interlocal Cooperation Act" provides legal authority for the parties to cooperate on the basis of mutual advantage to provide Emergency Ambulance Services in facilities for the needs and development of local communities; and further the Atomic Energy Act, 42 United States Code (U.S.C.) 2011 et seg., the Department of Energy Organization Act, 42 U.S.C. 7101 et sea., and the Stafford Disaster Relief and Emergency Assistance Act, 42 U.S.C. 5121 et seo., provide further authority for the DOE to enter into this agreement;

WHEREAS, it is necessary and desirable that an agreement be executed authorizing the interchange of such Emergency Ambulance Service between the parties. 
NOW, THEREFORE, IN CONSIDERATION OF THE MUTUAL PROMISES AND CONDITIONS CONTAINED HEREIN, THE PARTIES AGREE AS FOLLOHS:

\section{Duration of Agreement}

A. This agreement shall be effective as to each party when it has been approved by the governing bodies of the licensed ambulance services and shall continue to be effective for five (5) years from that date or until termination. The agreement may be terminated by any party by giving the other parties 30 days written notice.

B. Termination of this agreement may be effected by the governing body of each party adopted with the same formality as at the parties original approval of this agreement; provided that no such termination shall be effective until the expiration of 30 days after termination by either governing body. All the rights, remedies, and obligations of the parties will remain in effect until such 30 days expire.

C. The DOE will not be required to provide 30 days written notice if DOE determines that the department's mission or other national security matters make termination necessary.

2. Services Provided

Each party agrees that its emergency services and resources will be available to answer emergency calls within the jurisdiction of the other 
in order to provide adequate and tiaely Emergency Ambulance Service in accordance with the polictes and procedures as provided in Paragraph 4; provided, however, that no party to this agreement shall be required to make resources available or render service to any other party when by providing such services an unreasonable danger to lives or property of that party's residence or employees would result. The responsible persons designated by the governing bodies of each ambulance service or the service director for either party shall determine what resources and services can be reasonably provided this agreement. Neither party will be required to obtain additional resources of any nature to carry out this agreement.

\section{Emergencies}

Upon request by any of the parties and upon notification of an emergency occurring within the jurisdiction serviced by either party, the county or service may enter into the geographical boundaries of the other party to offer and render such Emergency Ambulance Service as either party deems appropriate under the circumstances. The county or service may provide such equipment and personnel of their ambulance service as it deems appropriate under the particular circumstances. An emergency occurrence as defined by this agreement consists of a situation beyond the normal and routine services being provided on a reqular basis by the responsible agency so that local resources are overwhelmed. This agreement in no

situation releases either party from having : :ailabie resources in order to fulfill day-to-day obligations being incurred by that party routinely. 
When a party responds to an emergency within the geographical boundaries of one of the other parties as contemplated by this agreement, the responding party may, but is not obligated to, charge a fee for services it deems necessary. Such fee would not be charged to the party requesting assistance but to the individual(s) transported by the responding party.

4. Policies and Procedures

The governing bodies of each licensed ambulance service do by this agreement authorize the county executive, mayor, ambulance service director, or their designee to establish the necessary policies and procedures to be followed in requesting and responding to requests for assistance provided such are authorized by applicable state or federal law, the ambulance service agreement if applicable and the mutual aid agreement.

5. Authority for Responding Personnel

A. In all occasions where emergency ambulance personnel travel from their geographical boundaries to that of another the jurisdiction, authority, rights, privileges, and immunities which they have in their jurisdiction shali extend to and be available to them in the geographical area they respond to.

B. The senior officer of the Emergency Ambulance Service, or his or her designee within his jurisdiction on the scene of an emergency shall be 
in command of the emergency as to strategy, tactics, and overall direction of the operation. Additional resources from outside the East Tennessee Region; 1.e., ambulance, air ambulances, hospital bed count, etc., will be coordinated by the Regional EMS Director.

All orders or directions regarding the operations of the party and the jurisdiction of the other party shall be relayed to the senfor officer in command of the party acting outside its jurisdiction provided, however, that neither this agreement or any agreements executed contemporaneous herewith shall be construed as creating a duty on the part of any party to stay at the scene of the emergency except as may be decided by the senior officer of that party.

C. Either party may depart the scene of the emergency at any time the senior officer of that party deems it appropriate at which time the senior officer of the other party shall be in complete command.

D. The Regional Resource Coordination Center will be used to coordinate communications with responding parties.

\section{Liability}

At any time a party requests the aid of another party, the requesting party shall not be liable for damages to the equipment or personnel of the responding party. Neither shall the requesting party, its officers, agents, or employees be liable for any damages caused by negligence of the 
personnel of the responding party while en route to or returning from the scene of an emergency.

7. Waiver of Claims

Each party hereby waives any and all claims against the other party for any costs, losses, damages, personal injuries, or wrongful death arising out of the operations of this agreement or for any loss or damage to their respective employees and property which may occur in the performance or nonperformance of this agreement. Each party will be responsible for furnishing its own equipment and personnel and shall be responsible for all expenses necessary for their operation.

8. Limits of Liability

This agreement is construed by the parties to be a function of the local governments to the extent that liability arises out of the performance of this agreement. Ambulance services under government control will avail themselves of the protection of the Tennessee Governmental Tort Liability Act as found in T.C.A. 19-20-101, et seg.

\section{Entire Agreement}

This agreement contains the entire agreement between the parties. Should a court of confident jurisdiction declare any provision of this agreement to be null and void or unenforceable, such provision shall be stricken but 
such determination shall not affect the validity of the remaining portions of this agreement.

U. S. DEPARTMENT OF ENERGY
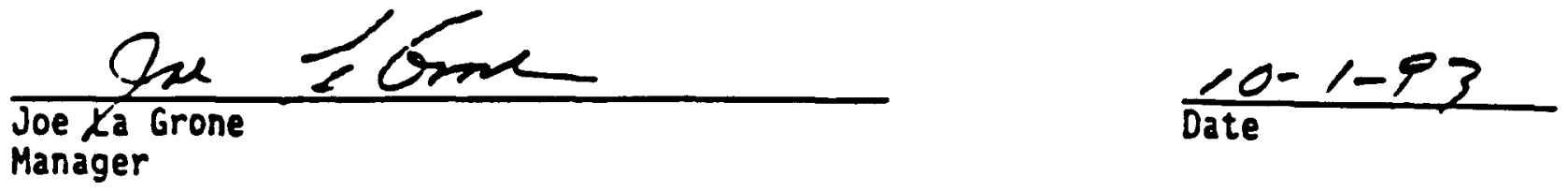

TENNESSEE DEPARTMENT OF HEALTH

EAST TENNESSEE REGION

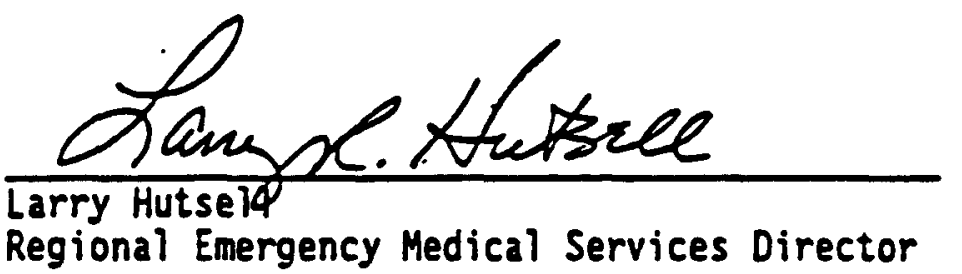

$$
\frac{9-21-93}{\text { Date }}
$$




\title{
LETTERS OF AGRBEMTNT COEMORANDUYS OP GNDERSTANDING
}

\begin{abstract}
A local law enforcenent mutual apreement has beeo nade botween the city of Oak Ridge and DOE. This leter can be accessed through the city of Oak Rldge.
\end{abstract}

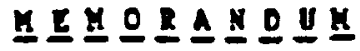

\author{
TO: Bonorable Kayor and \\ lubers of ary counell \\ Feax: H. LYle Lacy. III NTB: November 3, 1983 \\ CLEF unager \\ SOUJCT: SUPPLERTITL

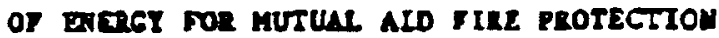

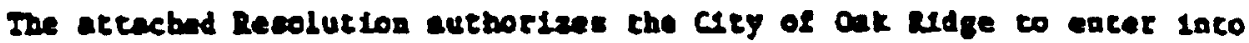

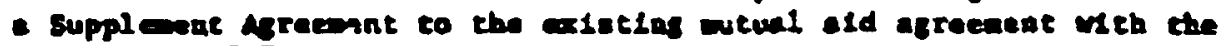
Doparteat of meret.

Thin mation's eperieace ofth latge ecele dieaters he focured atteotion on the ifportence of formuesng plan and orgasicational procedures for

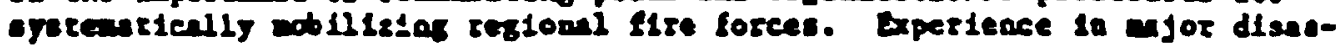

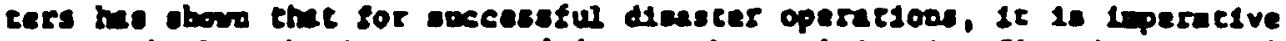

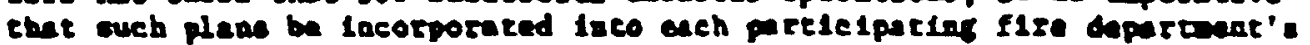

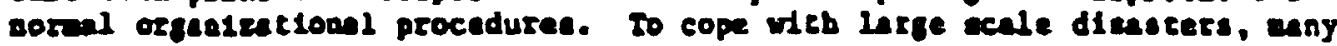

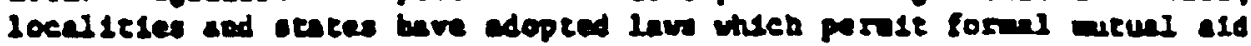
errecenten.

The concept of zutual add in the proviston of fenrgency cervicen in besed on

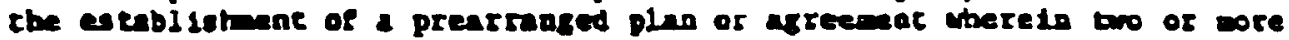

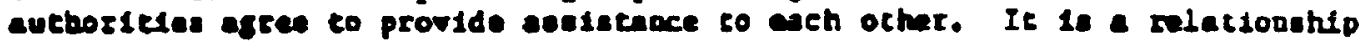

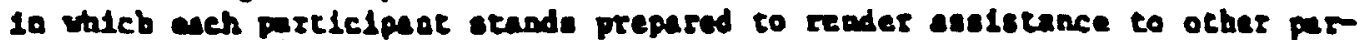
eles in the areate that an exergeacy cecurs of a agnitude beyood the lodi-

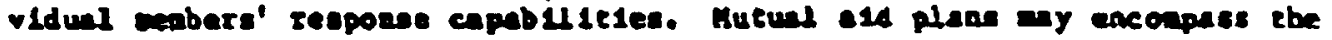
lollowing funceloas: oupplematal coverege then the anpower and equipaent of the requestag depertoent ore roppooding to an ancieocy and are engaged to arch an extent the 1 tes abllicy to furalsh adequet procection for oub-

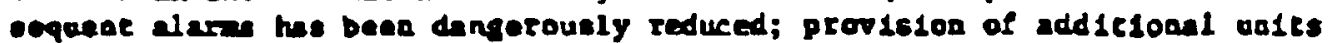
to andet at ajor flres or energoneles thet iffbe exceed the requestlag deparcarat' capebulties; and proviason of specialized cypes of firefightlof equipent aot possessed by cbe requestag depertmont. Typically. parties to witul id plane linst ouch assisence so that their orp jurisdiectone resin edequntely procectéd.

Frod as enty as 1960, mutual aid fire protection agreemeats have existed between the c1ty and the varlous lederal asencles responatble for operation of the govermat plance and laboratory la Oak Ridge. The last af these

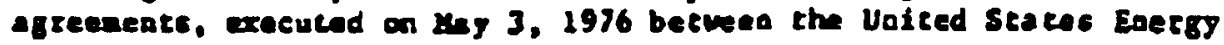

Drafe Incerin Plas. 3/87

$$
\text { IV-P-1 }
$$




$$
-2-
$$

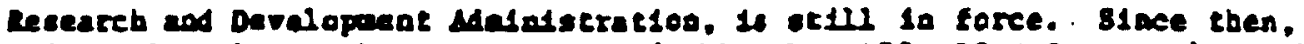

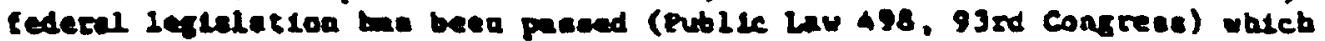

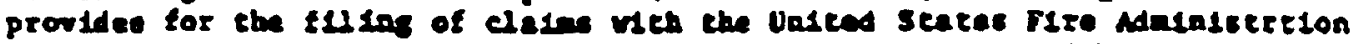
to recover the eount of direct losees and expensen locurted by malc1pal1-

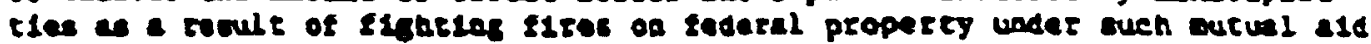
agrewmats. Thece changer and developmants bve crenced the and to update the cistine any 3, 1976 autual ald agreaseat through the execution of thts eppolearens.

Approvel of the atrached reeolution is recounended.

tat

Atcactonac

Draft Interin Plan, $3 / 87$ 
EESOLUTOR

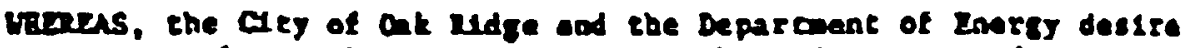

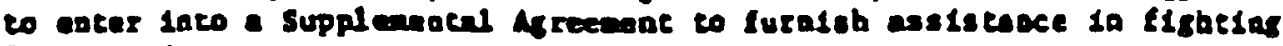
Elres, and

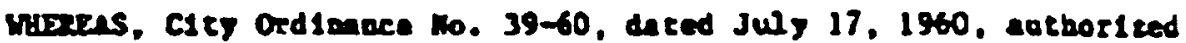

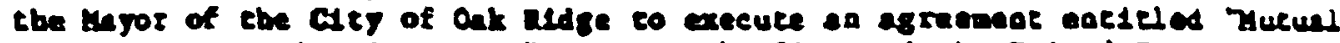

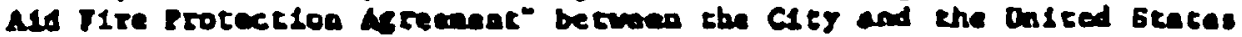
Atonic Inergy Conesseron, and

imerns, Conpter 223, Nublic sets of 1957 (Seet1oo 6-54-601 et seq.,

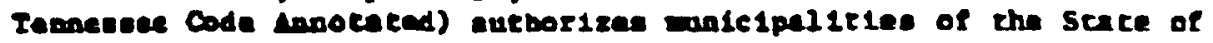

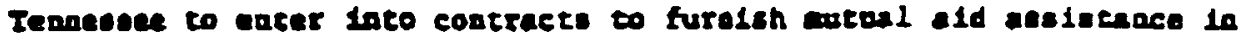
esphtar eires, and

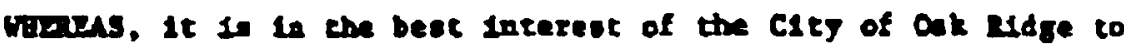
exceste che cane.

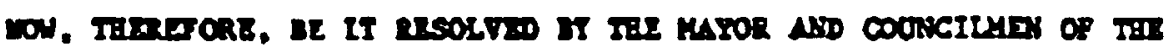
CIEl of our RIOCL, ILOWESSE:

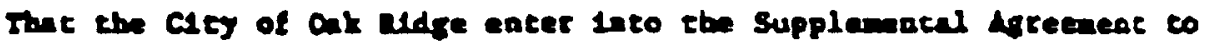

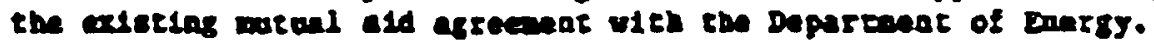

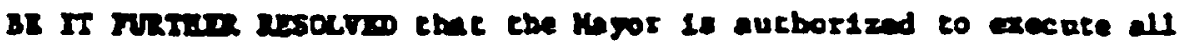

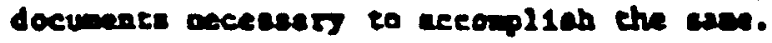

Thts the $7 \mathrm{kh}$ deg of Iovmber 1983.

Aproven as to rore

Ail LFeIR:

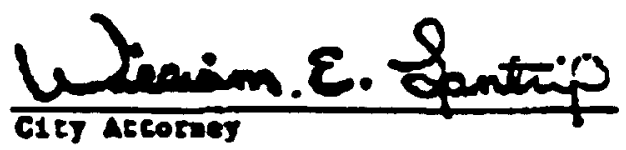




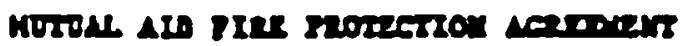

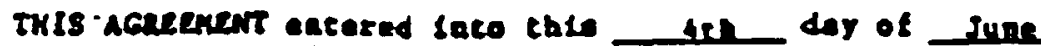

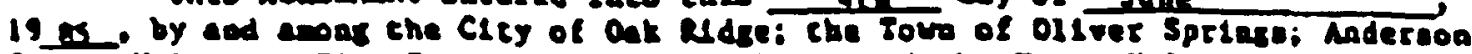

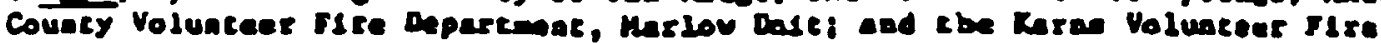
Departeane.

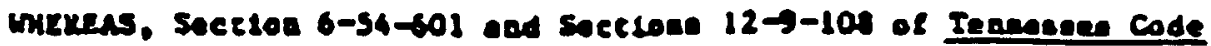

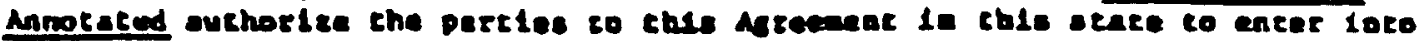

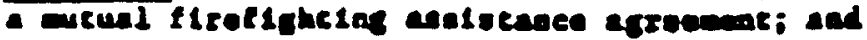

whereas, the parties berete desse co evall themelves of the euchortey coaferred by chle law; and

uncens, the purpose of thls agreecese 10 co provide each of the per-

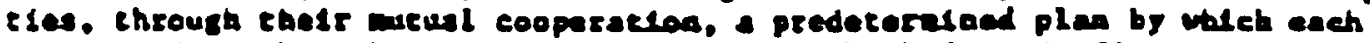
render ald to the other it eave of enereney ubleh derande flre procection serv-

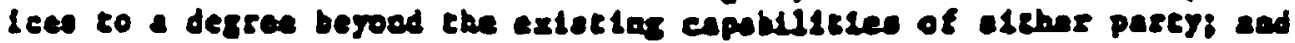

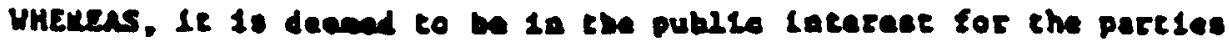

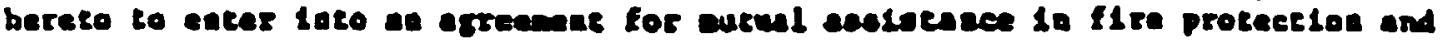

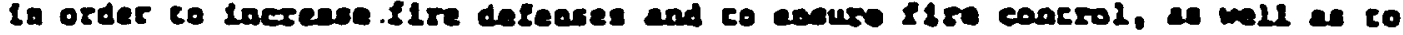

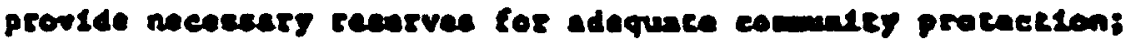

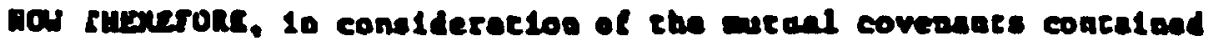

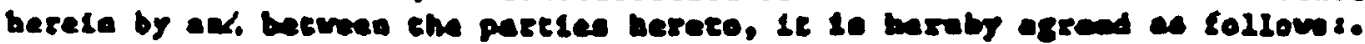

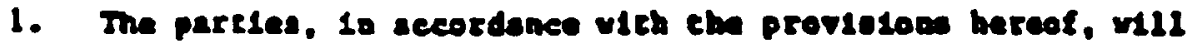

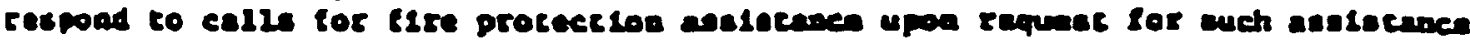

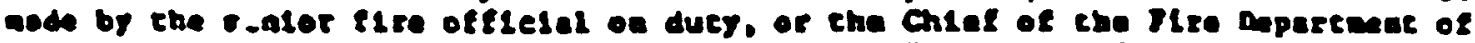

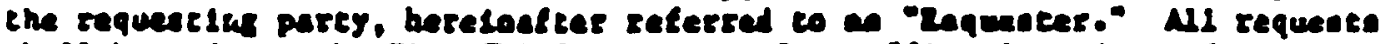

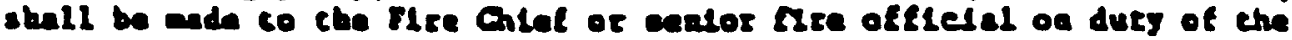

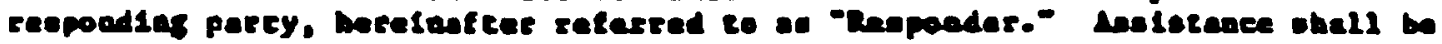

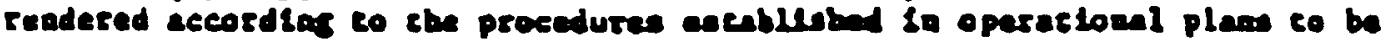
developed and agread to by the Individunl pareles, and In accordence vich rbe propleloas herool.

2. Upos recelpe of a requese lor eselstesed of the oublor fire offl-

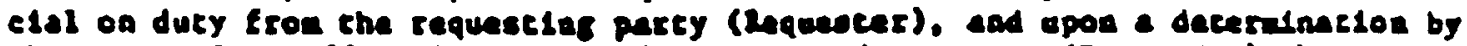
the cantor lire offletal on duey of the respondlas porty (reopoader) chet

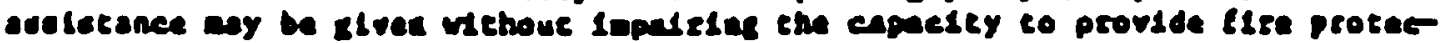

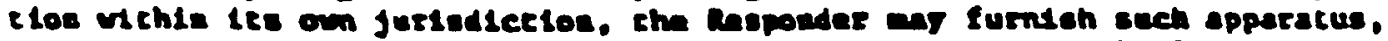

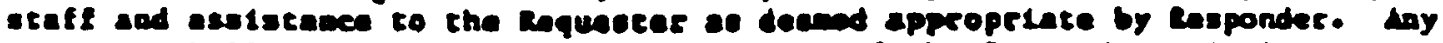

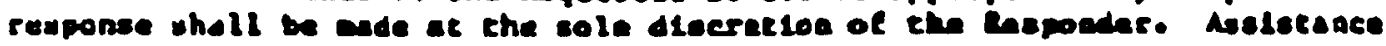
sholl be reedered accordleg to the procedures escablisbed in the oparaclonal

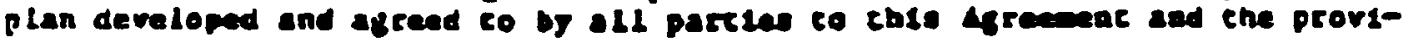
sions hercol.

Deate Interin Plan. $3 / 87$

IV-I 


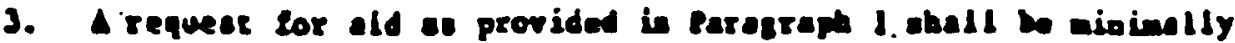

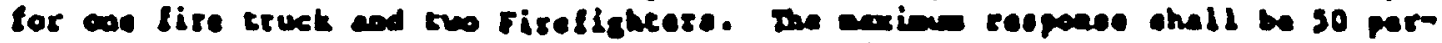

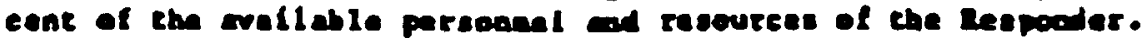

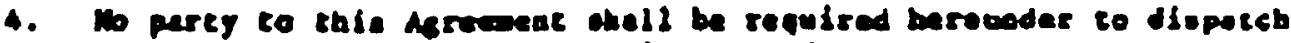

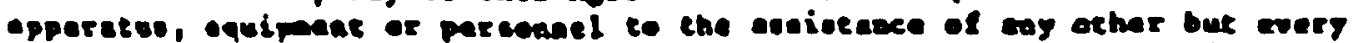

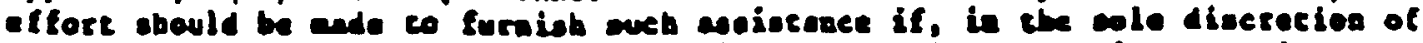

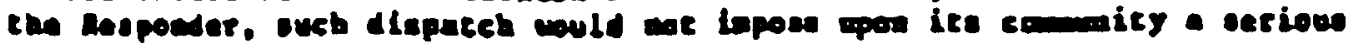

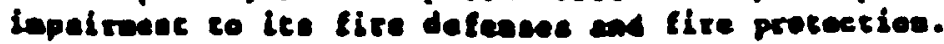

5. If the heoponder detersices no asiecance can the readered, or if

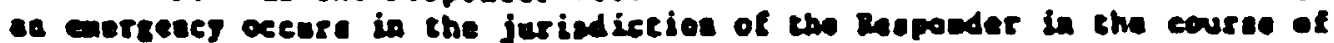

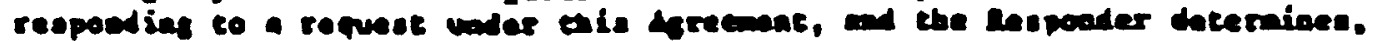

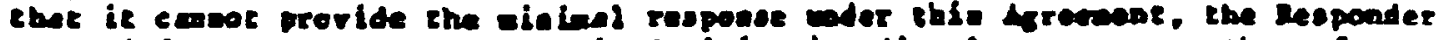

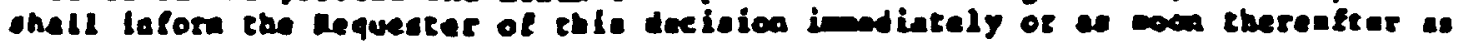
poesible.

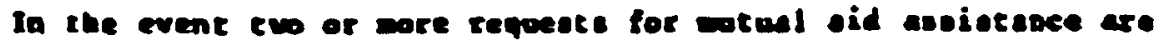

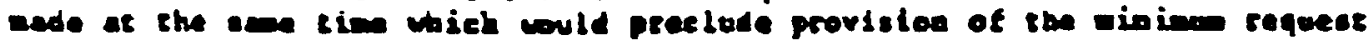

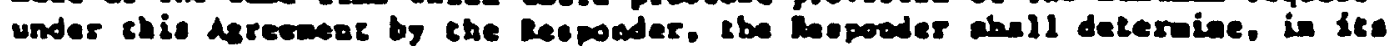

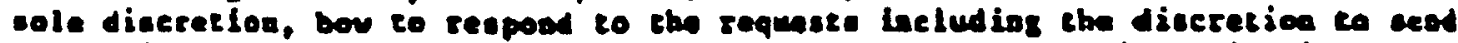

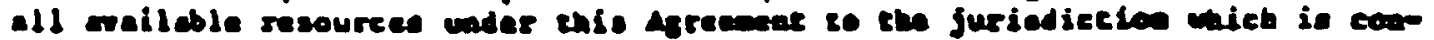

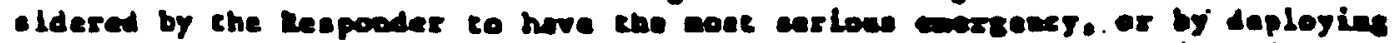

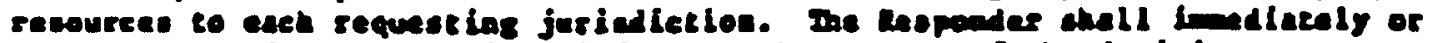

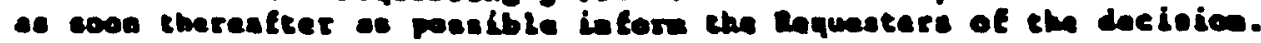

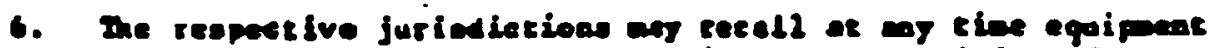

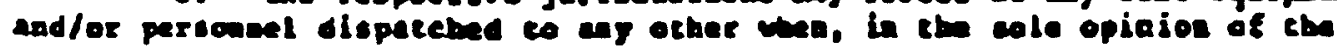

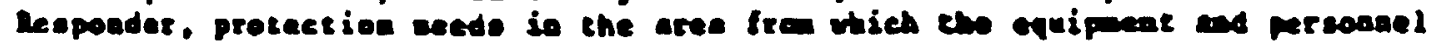
wre dieperenes to require.

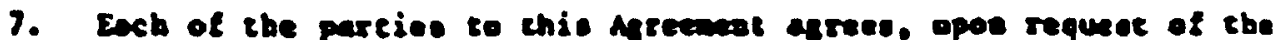

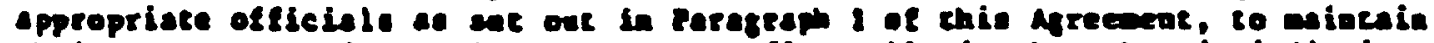

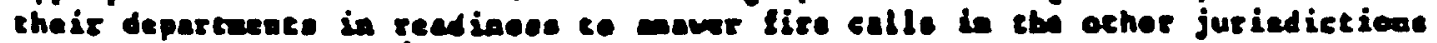

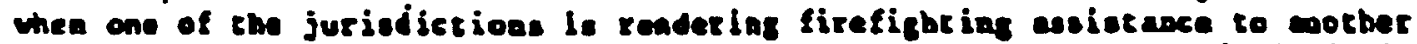

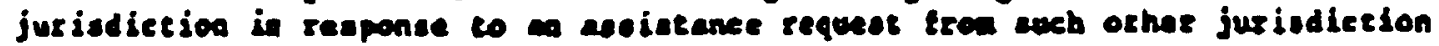
pursuent to keis agrecinat.

8. The Respoder thatl only diepeteh pereoenel thet are reoponsible

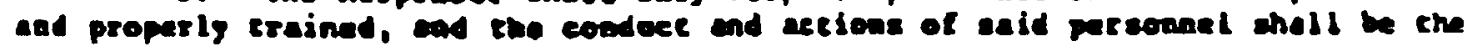
resposeability of ene reapeader.

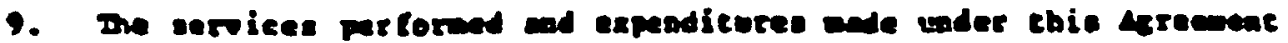
tre to be ande selely for public and gevercmetal purpoces.

10. hay personsel chall ouly be atilized is she course acd scope of

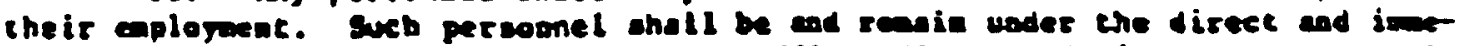
dicte control of the center firefighties officer dispatcbed virh ooch persoudel, and ouch officer aball uleipately direct and conerol or apprase the urilisatieg of eucb peroonel ouch persosnel chell in we cace be deced eployeer or agents of, oor loaned servanto to the Requester.

Draft Interin Plan. 3/a7

IV $-\mathbf{F}-8$ 
11. Whea secistance is rewerëd pureunet so chis agrecent by arey

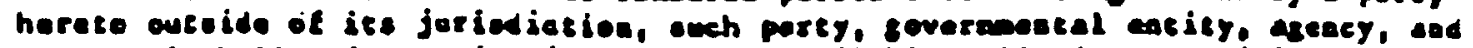
personal oball cajoy, quiacein, and have ovaileble, all. righct, privilezes ad leanicles provlded by lav.

12. Eoch patey co thlo agrement jointly an eeverally bereby releace, reaise, had forever discharge exeh ad every exber parky herefo from any and ali

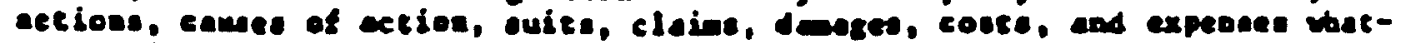

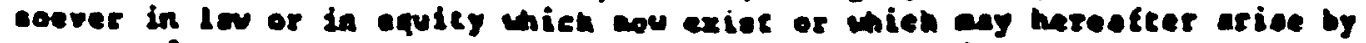

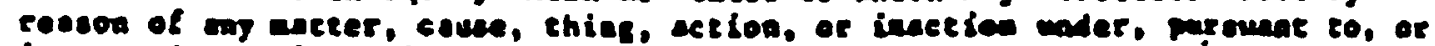
ia secerdeace with this Astecuens.

13. All parties harete astre to anow and has oll coste and copmest

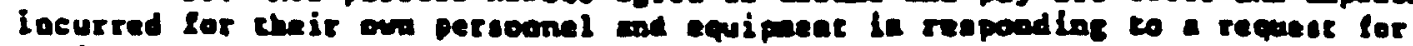

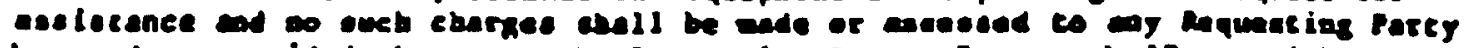

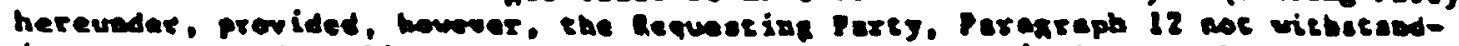

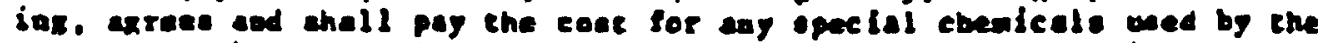
heoponding firty frow its an oupply. Such coots whell be paid promely on presearation of an itemised scatereat.

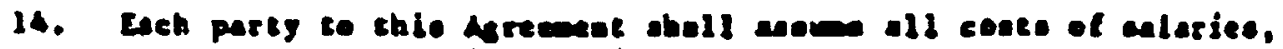

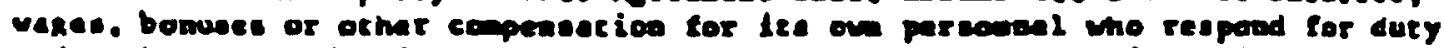

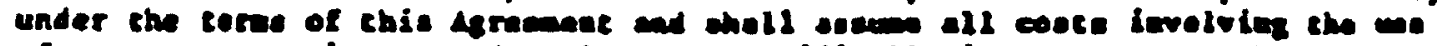

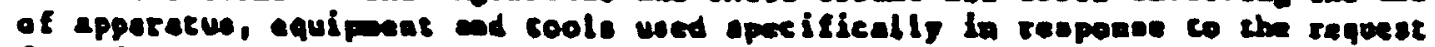
for aid and chall whe wo cherge fo: wet we co the porty requasies

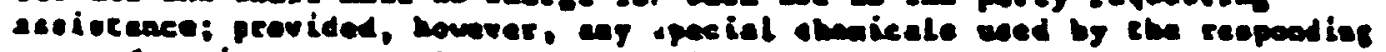

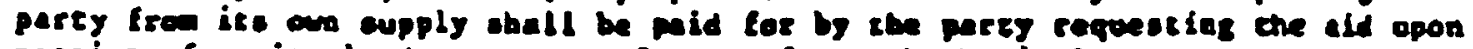

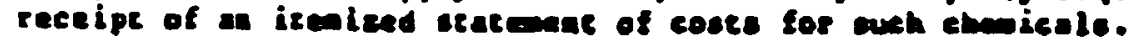

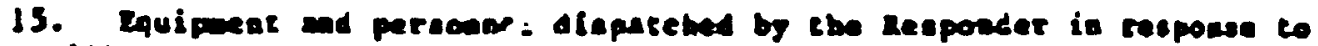
a requese will pperate under the inadince eppervisien and cootrol of tbe seaior

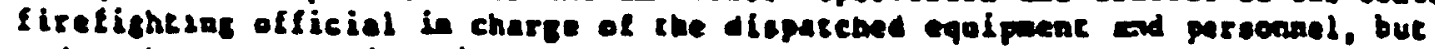

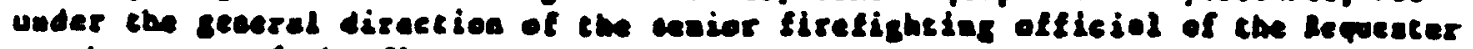
at the ceane of cbe fire.

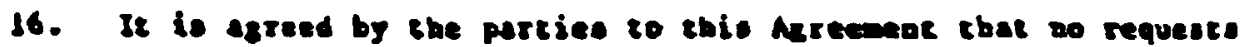
will be ande, eor any asciekenee rentered, for fires occurries wteide the juratictional linjes of the Requester.

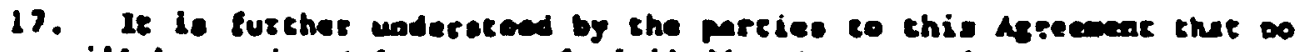
eserecence vill be rendered in cases of civil disorter. or rioes, eacept esur

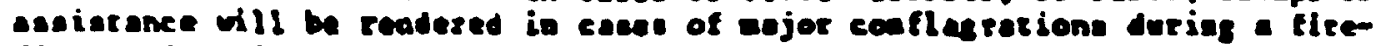

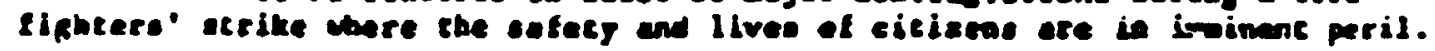

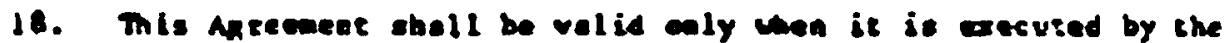
Chsef Execusive offlet of the respersive parties prewant te the athority duly pranted by the goveralag bodles of such parties.

Drate Interín Plan. $3 / 87$

IV $-\mathbf{F}-\mathbf{9}$ 
19. Ins Agretent enpereedes and repleces ay and all murual atd

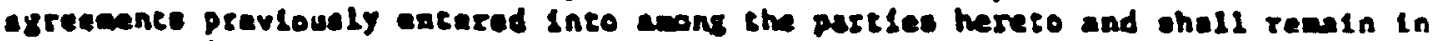
effece wotfl terviasted by all parcles maraco in the form of uritcen notlee cetelog forth the date of cerninacion. day one party hereto wa ubtbdran frow chls Agreeneat and cernfante 15 with regard to ther party. Such witbdravel

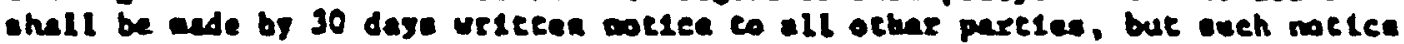

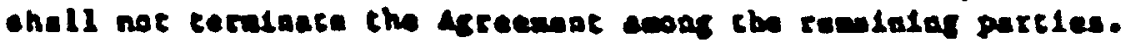

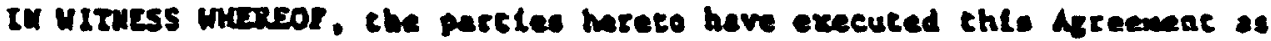
of the dece firat above vritcea.

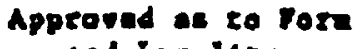

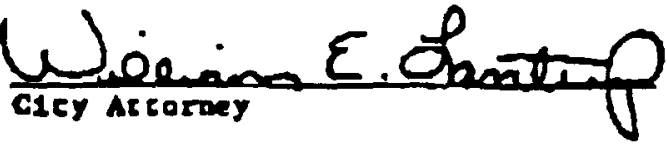

\section{CITY OF OAK RLDGE}

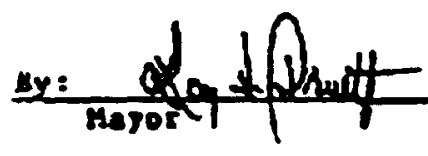

.

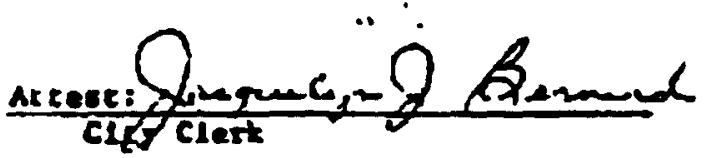

ron or oltvis smimos

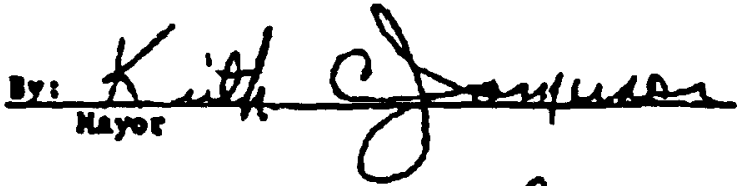

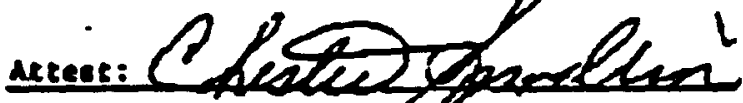

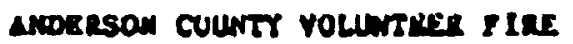
ocperguex, maves uner

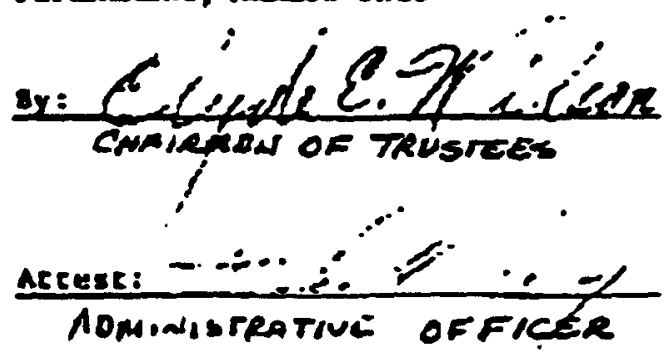

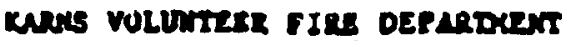
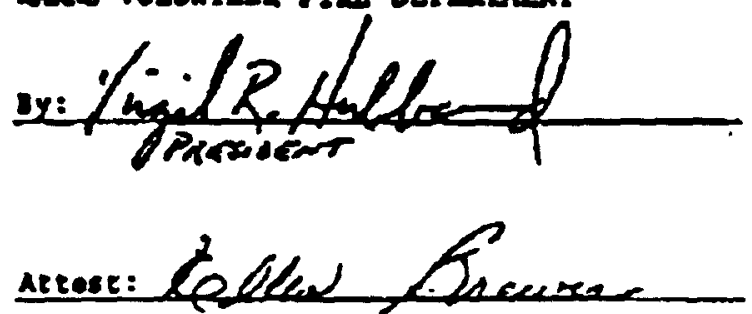

Dratt Interie Plan. $3 / 87$

IV-F-10 


\section{During an}

Emergency Evacuation,

Go to Assembly Station 10

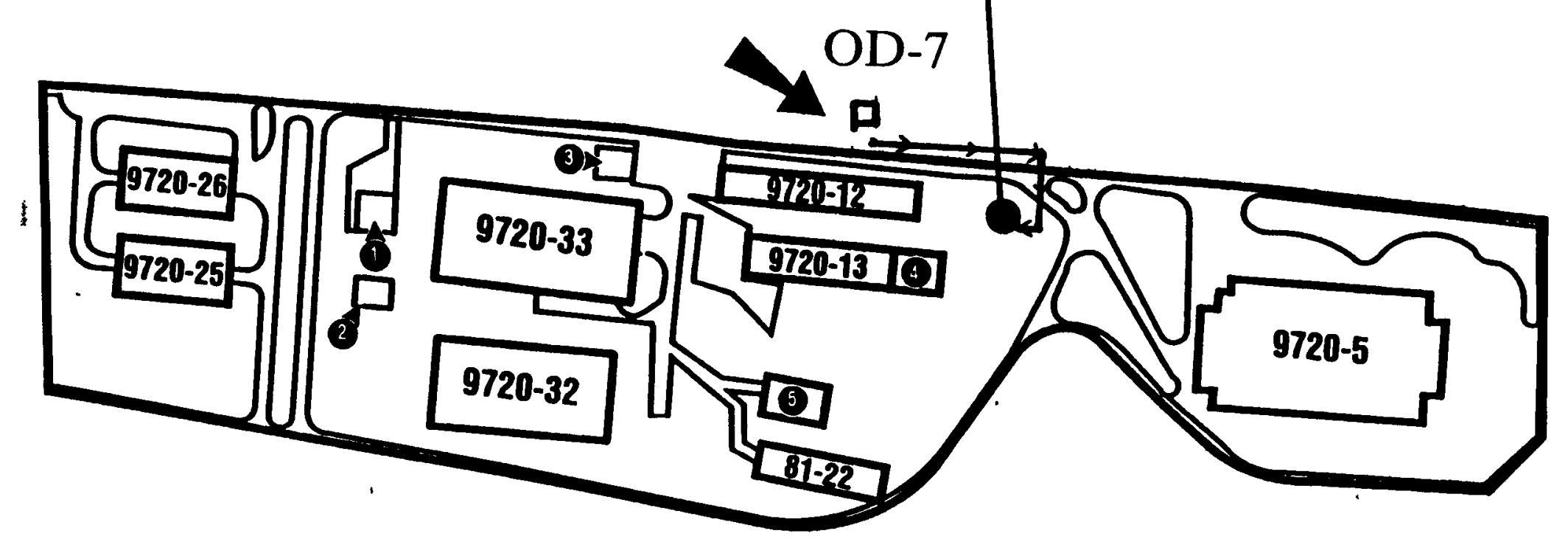

-

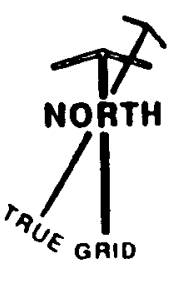

Figure 5

OD-7

EVACUATION ROUTE 


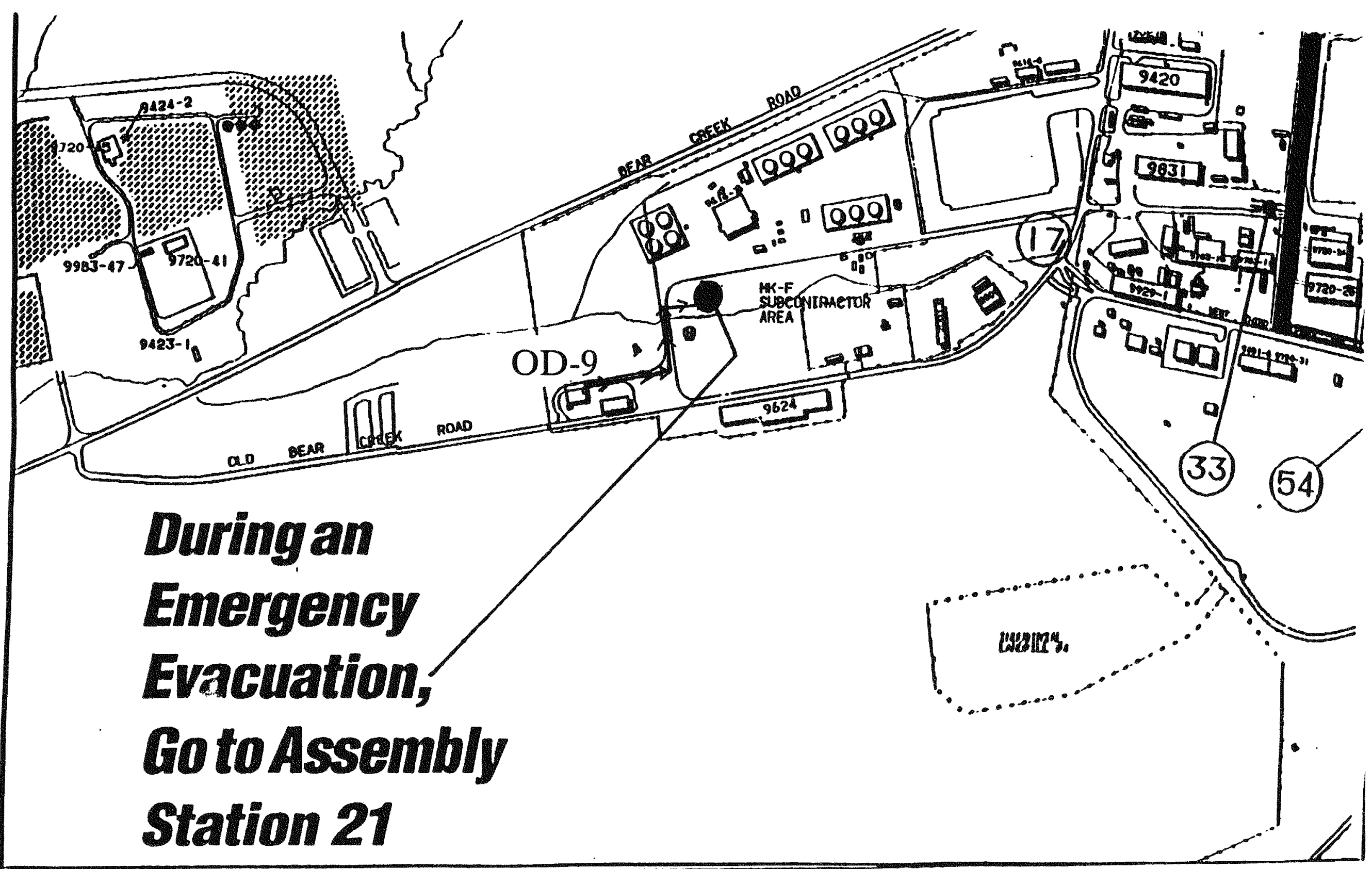

Figure 6

OD-9

EVACUATION ROUTE 


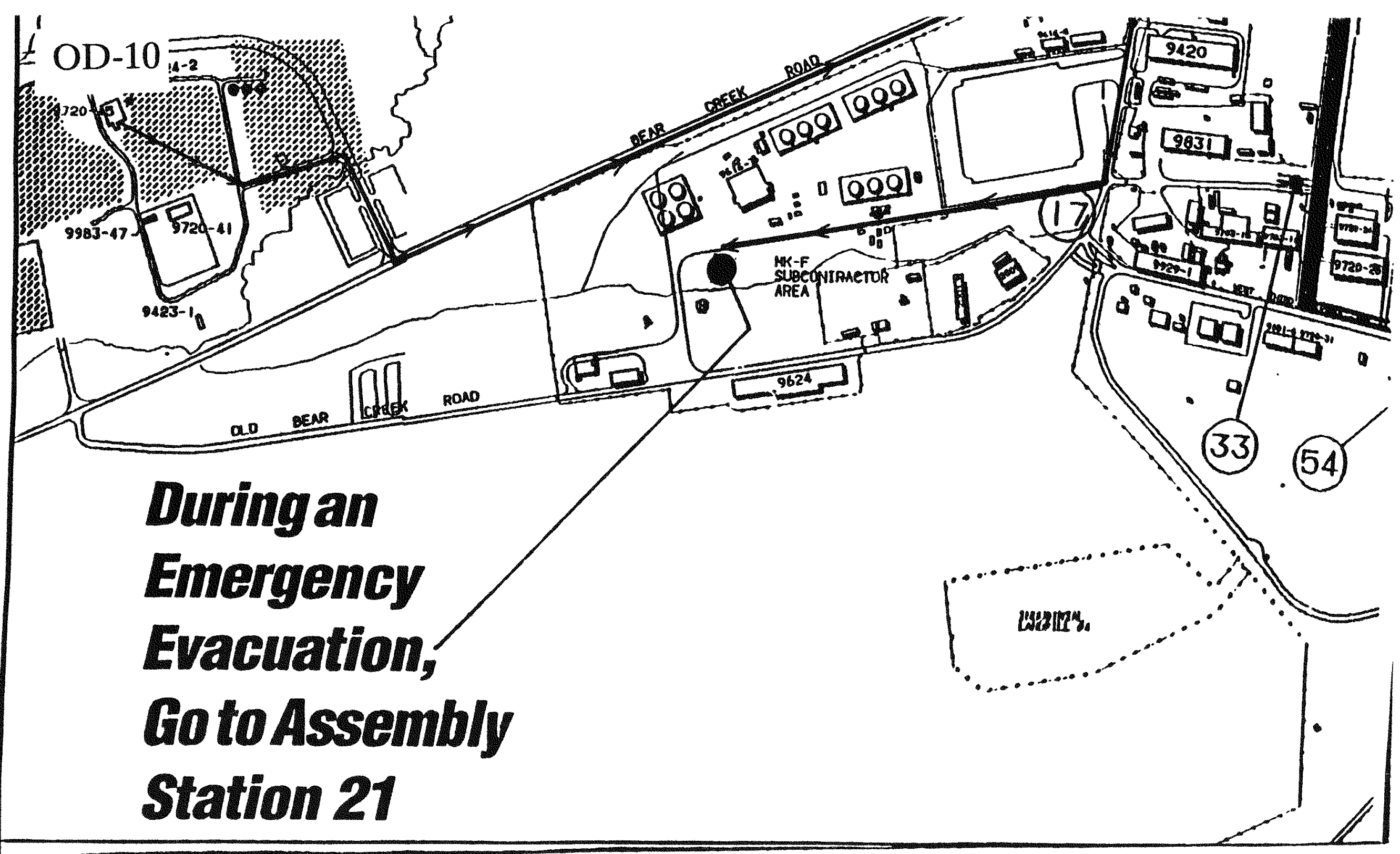

Figure 7

OD-10

EVACUATION ROUTE 


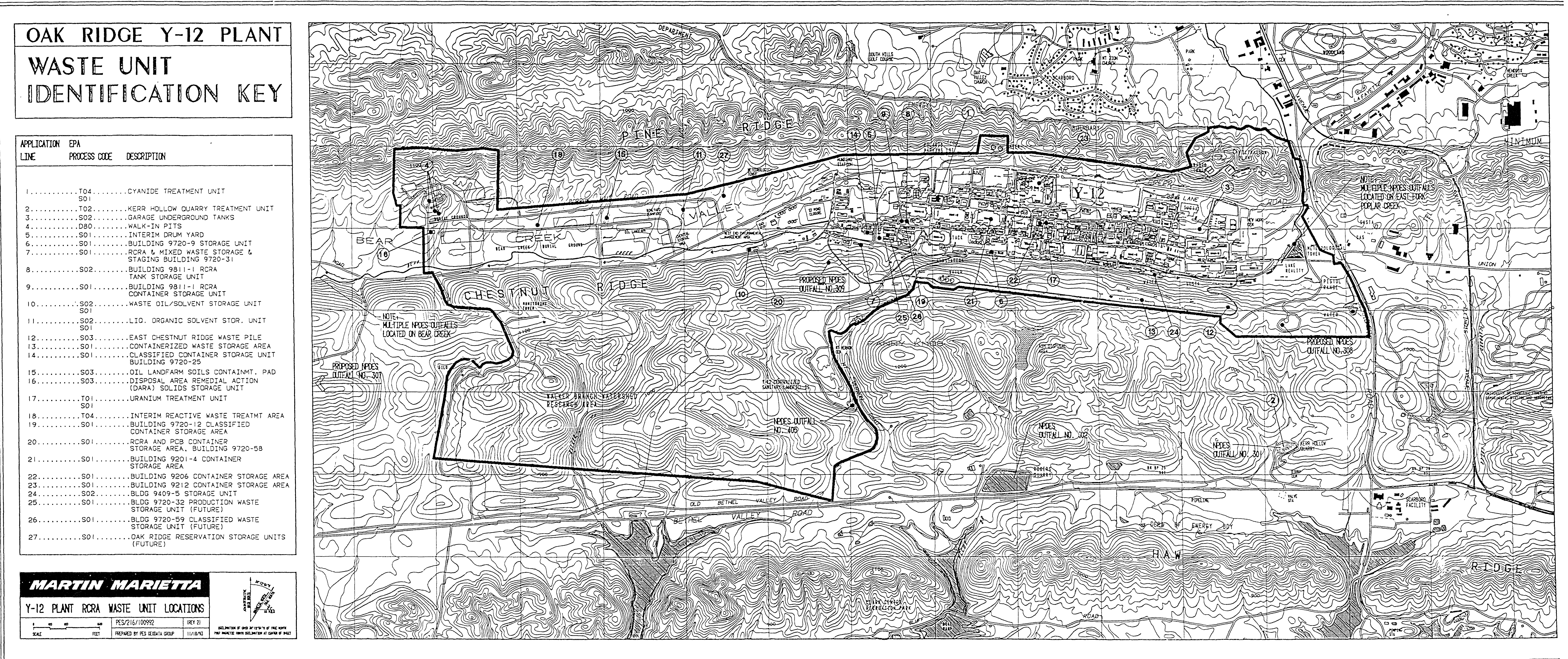




\section{Y-12. PLANT \\ BEAR CREEK \\ BURIAL GROUNDS}

\section{LEGEND}

(1) Dara solids storage unit

(2) dara liouid storage. \& treatment unit

(3) INTERIM REACTIVE WASTE TREATMENT AREA

(4) oil LandFarm soils containment pad

5 WALK-IN PITS

6. Liouid organic solvent storage Unit

- gamewell box locations

access control gates

DOE 229 boUndarY

WATH WAFITA

Y-12 PLANT WASTE UNITS

\begin{tabular}{|l|l|}
\hline ISFP/284/081|92 & (REY II) \\
\hline
\end{tabular}

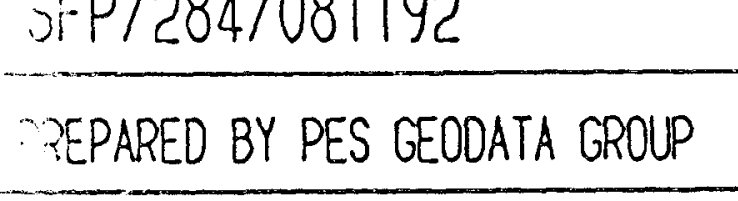

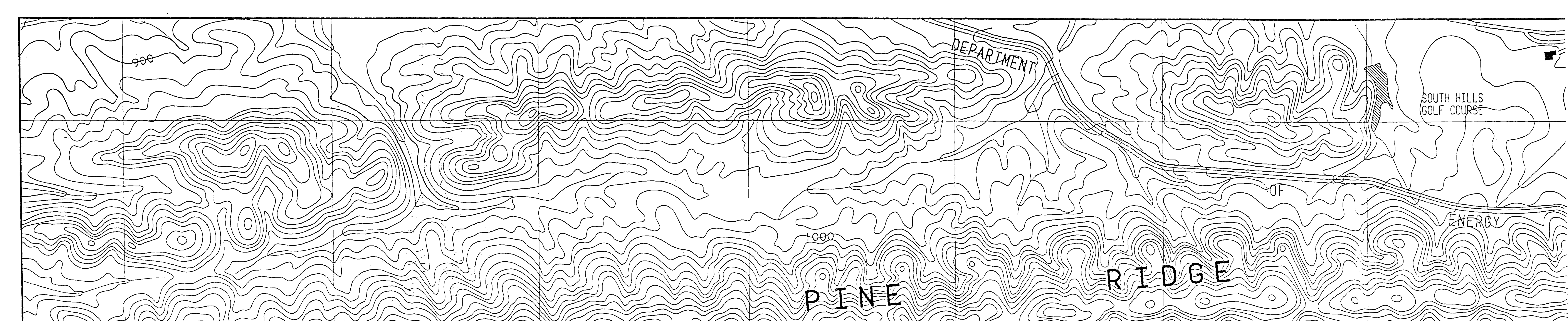

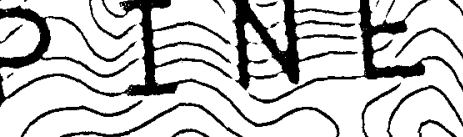
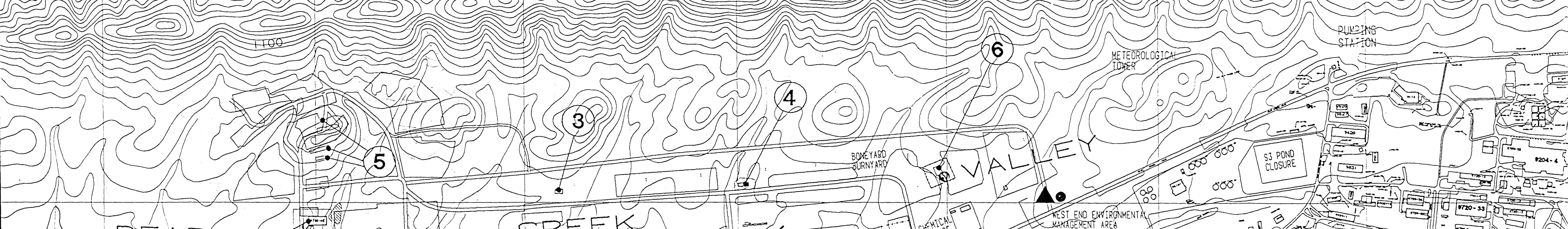

(1)

A
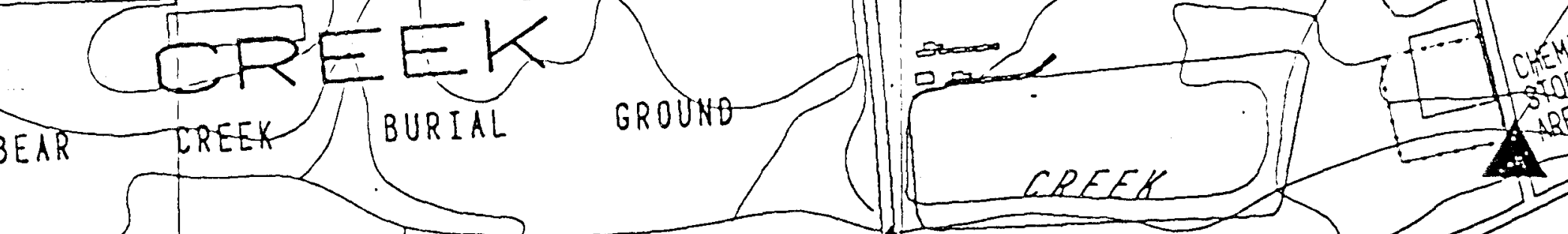

70

CHESTNUT B DEGE

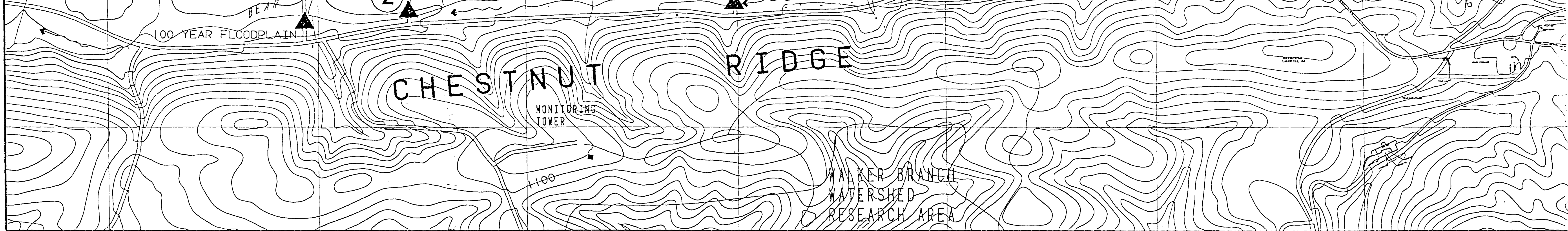




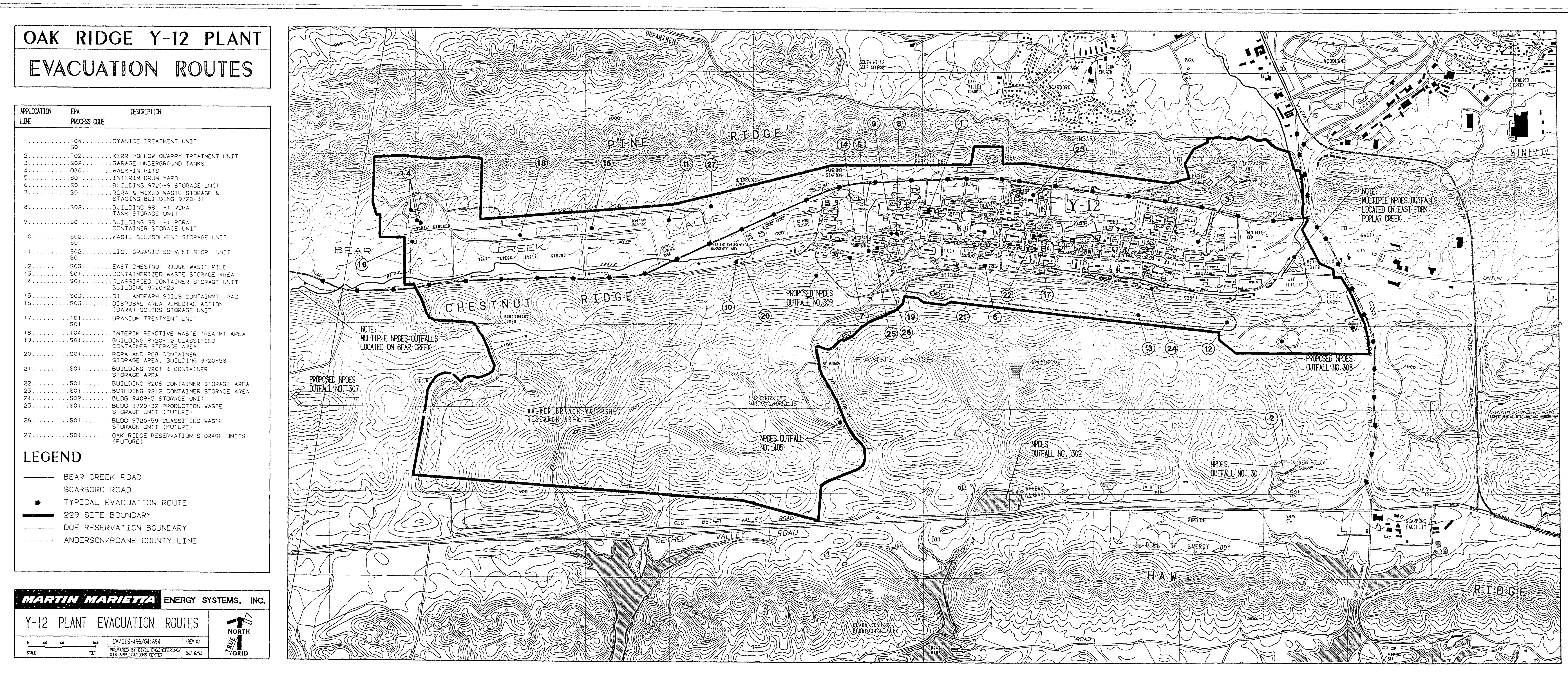




\section{OAK RIDGE $\mathrm{Y}-12$ FACILITIES MAP}

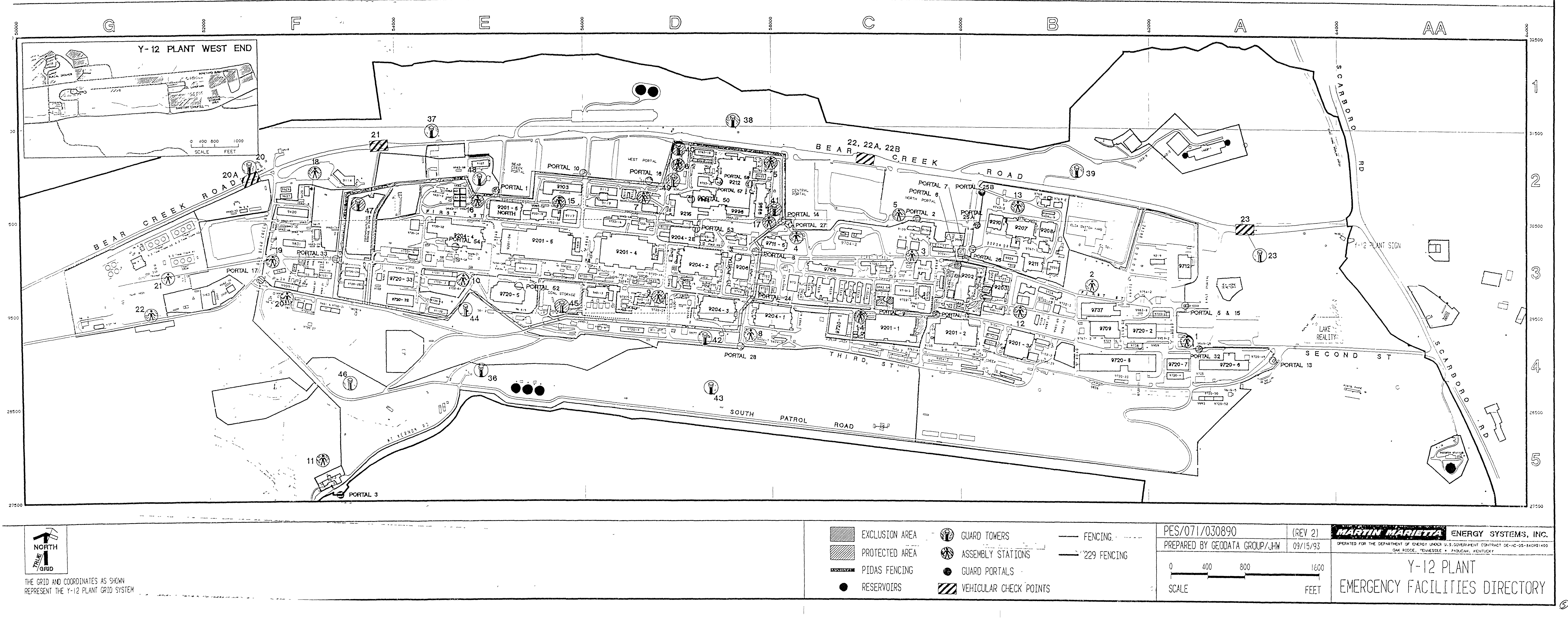




\section{OAK RIDGE Y-12 PLANT WASTE UNIT IDENTIFICATION KEY}

\begin{tabular}{|c|c|c|}
\hline $\begin{array}{ll}\text { Lopichition } & \text { E } \\
\text { LuE } & p\end{array}$ & 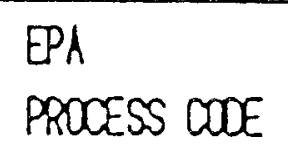 & DESRPPITIN \\
\hline & . 104 & CrAMNDE TREATNEN WNET \\
\hline & $\begin{array}{l}.102 .2 \\
.502\end{array}$ & 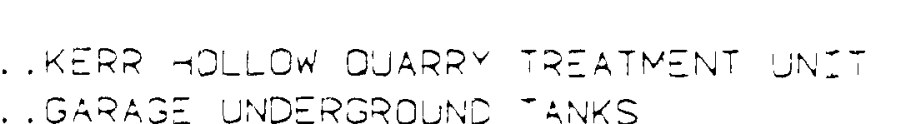 \\
\hline & $\begin{array}{l}.080 ! \\
.501\end{array}$ & 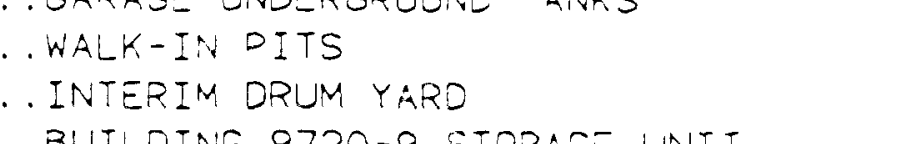 \\
\hline${ }^{6}$ & $\begin{array}{l}.501 \\
\text { sol }\end{array}$ & 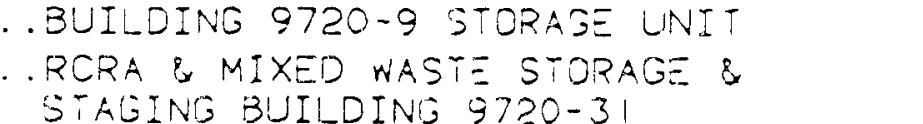 \\
\hline 3 & .502. & 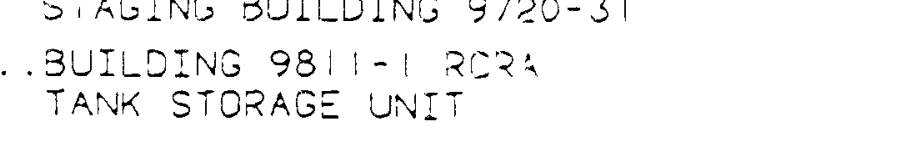 \\
\hline & .501. & 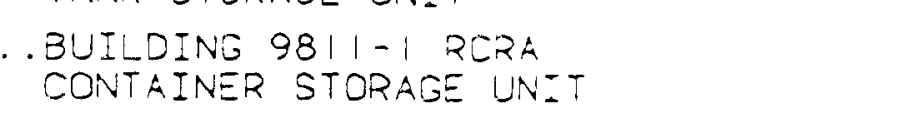 \\
\hline 10. & 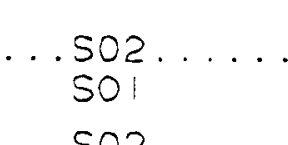 & WASTE OLL SOVVENT STORAGE UNIT \\
\hline & 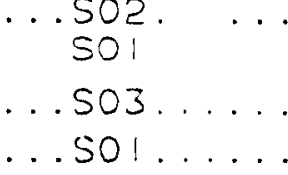 & 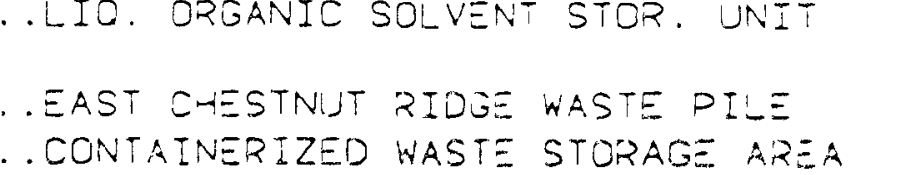 \\
\hline & & 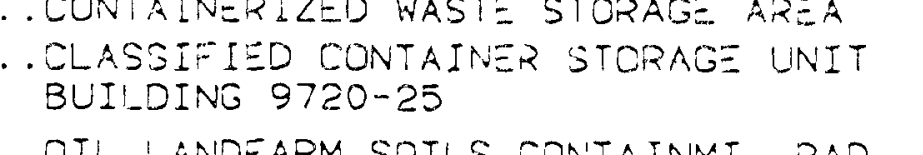 \\
\hline $\begin{array}{l}15 \ldots . . \\
16 \ldots \\
16\end{array}$ & s033. & 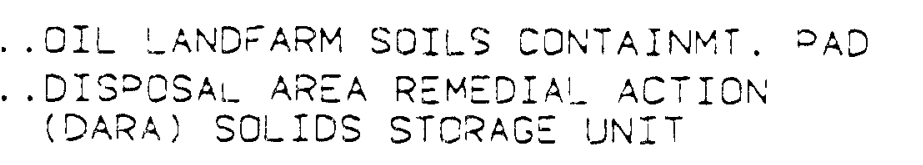 \\
\hline & $\begin{array}{l}.101 . \\
\text { sol. }\end{array}$ & - UAANIM TREATNENT UNIT \\
\hline $\begin{array}{l}18 . . \\
19 . .\end{array}$ & . 500. & 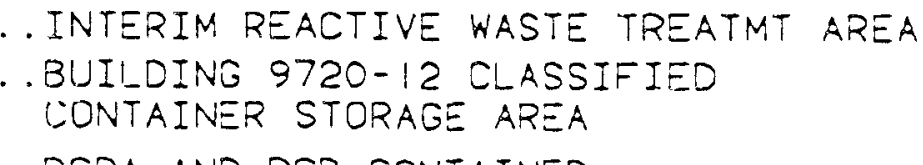 \\
\hline $\begin{array}{l}20 . \\
21 .\end{array}$ & .501. & 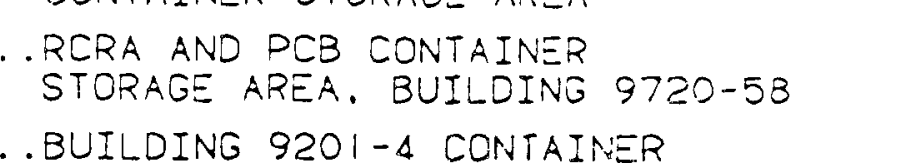 \\
\hline & .501. & 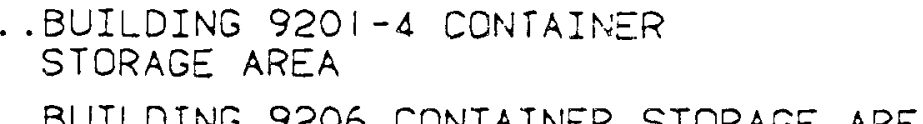 \\
\hline 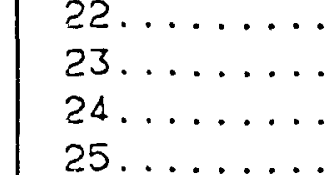 & 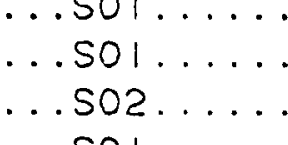 & 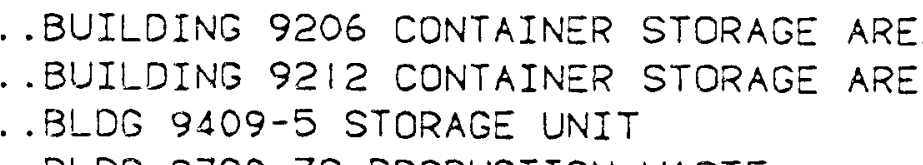 \\
\hline 26. & $\ldots$... & 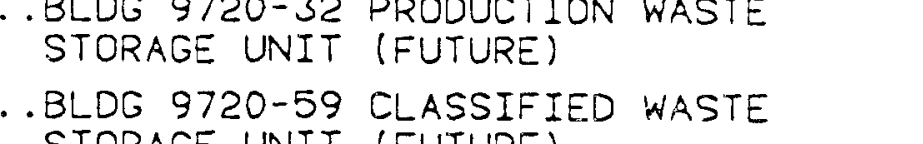 \\
\hline & 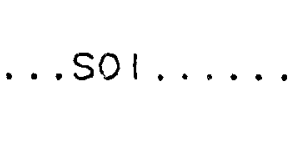 & 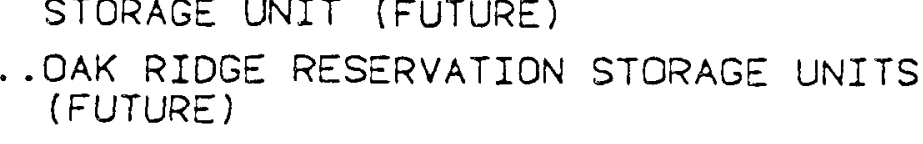 \\
\hline
\end{tabular}

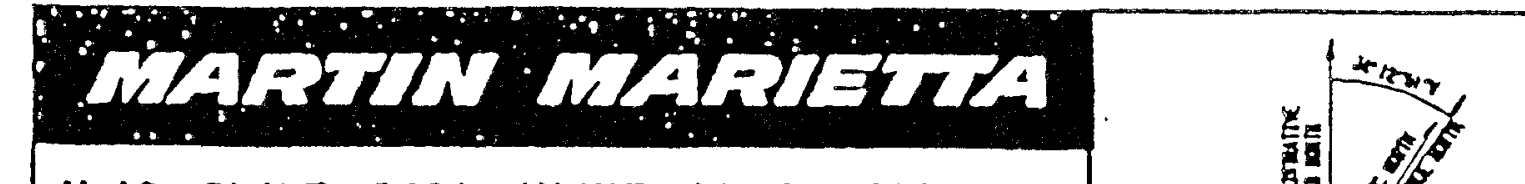

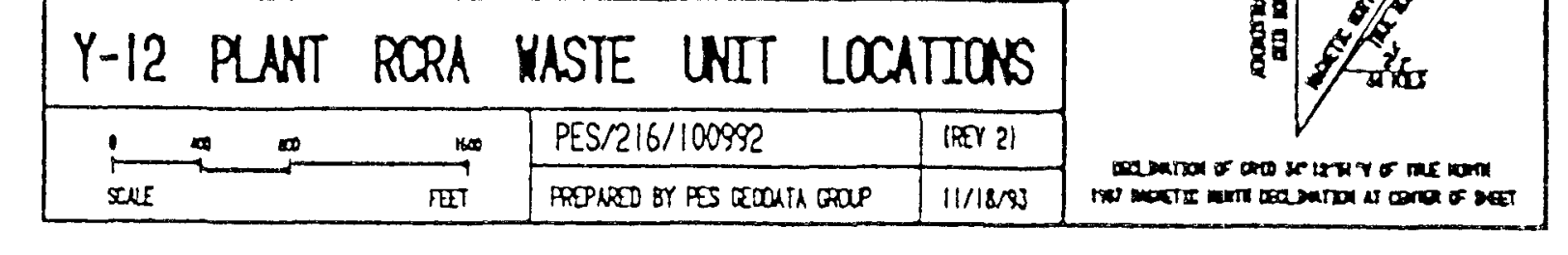

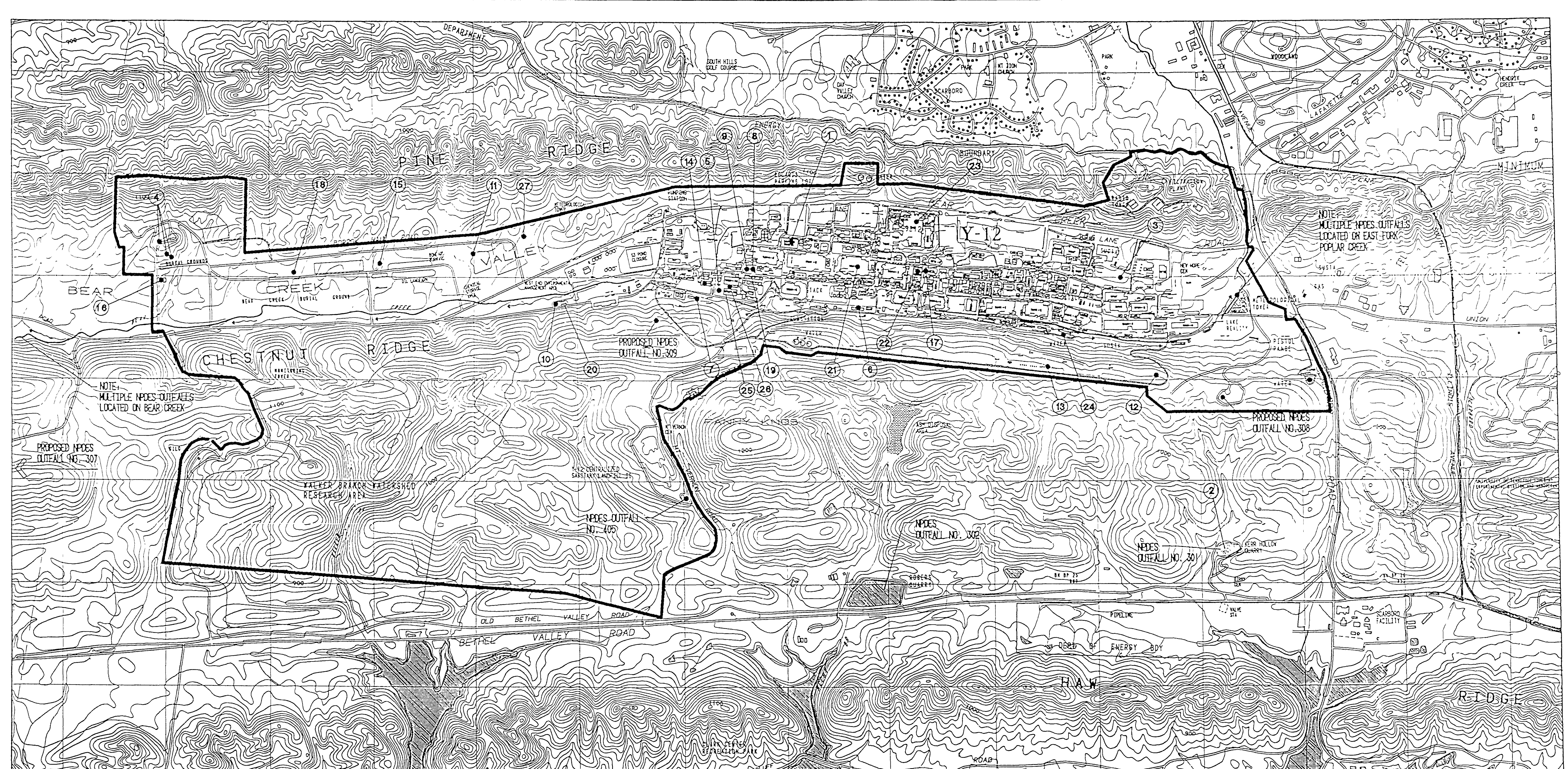

(I) ( 


\section{Y-12 FLOOD PLAIN}

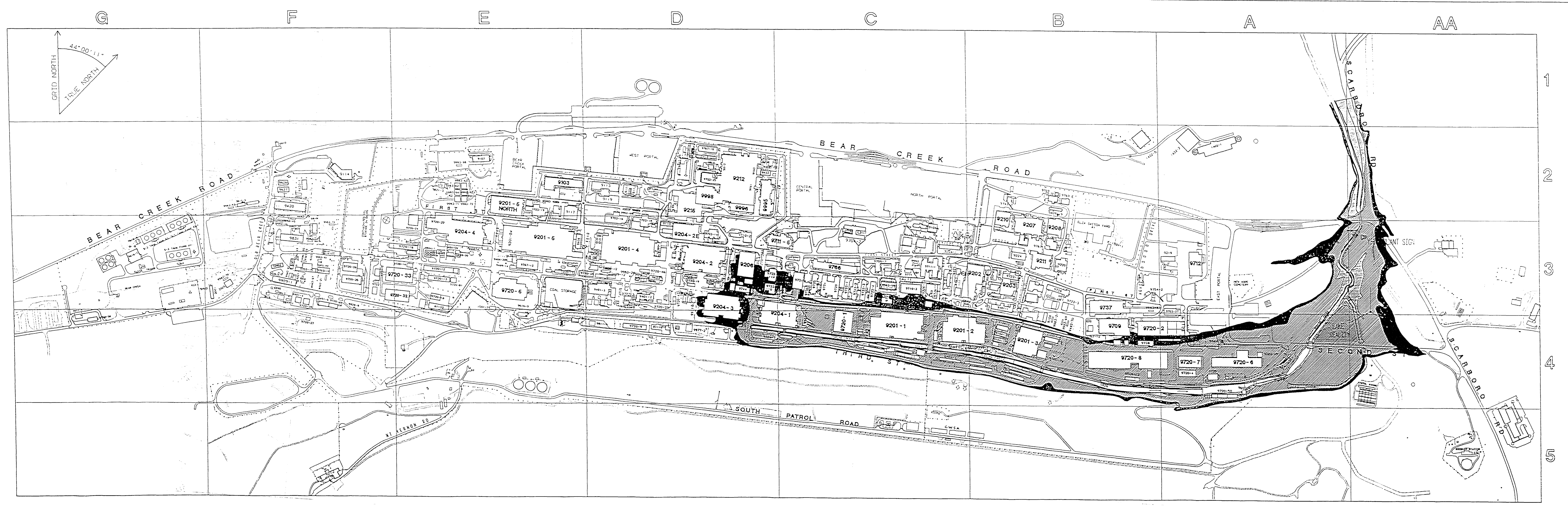

LEGEND

PROBABLE MAXIMUM FLOOD

MAXIMUM PROBABLE FLOOD

500 YEAR FLOOD 
External Distribution:

Mr. Mack Bailey

Fire Department Chief

City of Oak Ridge

Post Office Box 1

Oak Ridge, Tennessee 37831

Mr. David Bolling

Anderson County Executive

100 North Main Street

Clinton, Tennessee 37716

Mr. Timothy Braaten

Chief of Police

City of Oak Ridge

Post Office Box 1

Oak Ridge, Tennessee 37831

Mr. Wayne Britt

University of Tennessee Lifestar

1924 Alcoa Highway, Box 103

Knoxville, Tennessee 37920

Mr. Jeff Broughton

City Manager

City of Oak Ridge

Post Office Box 1

Oak Ridge, Tennessee 37831

Mr. Arnold Clower

Roane County Sheriff

100 Race Street

Kingston, Tennessee 37763

Mr. Kenneth Fritts

Anderson County Local Emergency Planning Committee

Route 2, Box 980

Heiskell, Tennessee 37754

Mr. David L. Hatton

Chief, Volunteer Fire Department

Anderson County Marlow Unit

Route 8, Box 410

Clinton, Tennessee 37716

Mr. Virgil Hubbard

Chief, Karns Volunteer Fire Department

Post Office Box 7184

Knoxville, Tennessee 37921 
Mr. Larry Hutsell, Director

Regional Emergency Medical Services

Tennessee Department of Health

1522 Cherokee Trail

Post Office Box 59019

Knoxville, Tennessee 37950-9019

Mr. Phil Keith

Knox County Local Emergency Planning Committee

City-County Building

Knoxville, Tennessee 37901

Mr. George Matthews

Administrator

Methodist Medical Center of Oak Ridge

990 Oak Ridge Turnpike

Oak Ridge, Tennessee 37830

Mr. Robert McKamey

Anderson County Ambulance Service

103 South Charles Seiver Boulevard

Clinton, Tennessee 37716

Mr. Bowden Ladd

Roane County Ambulance Service

Route 8, Box 198

Harriman, Tennessee 37748

Mr. LeRoy Mitchell

Roane County Emergency Director

Post Office Box 43

Rockwood, Tennessee 37854

Mr. Russell Newman

Tennessee Emergency Management Agency

836 Louisville Road

Alcoa, Tennessee 37701

The Honorable James L. Session

Mayor of Oliver Springs

607 Easterbrook Avenue

Oliver Springs, Tennessee 37840

Mr. Charles Sitzlar

Tennessee Emergency Management Agency

836 Louisville Road

Alcoa, Tennessee 37701 
Ms. Lacy Suiter

Tennessee Emergency Management Agency

State Emergency Operations Center

3041 Sideo Drive

Nashville, Tennessee 37204-1502

Mr. Lloyd Terry

Loudon County Local Emergency Planning Committee

Post Office Box 312

Loudon, Tennessee 37774

Mr. Ken Yeager

Roane County Local Emergency Planning Committee

Post Office Box 43

Rockwood, Tennessee 37854 
Internal Distribution:

M. R. Anderson

D. M. Best

D. L. Bird

L. Boshears

S. A. Bowen

R. W. Boyd

J. T. Bryson

R. W. Burnett

L. C. Cappiello

J. A. Coffey

D. L. Daniels

C. D. Davis

D. E. Deel

J. C. Drewery

O. E. Duncan

M. S. Dunn

H. J. Foster

R. V. Fowler

J. R. Frost

M. A. Guinn

L. Y. Guerrero

C. C. Hill

W. Howard, Jr.

G. L. Humphrey

K. D. Hunt

P. L. Hyman

C. E. Irwin

M. E. Johnson

M. H. Johnson

R. M. Keyser/J. E. Powell

C. M. LaBorde/M. S. Burris

A. K. Ladd

A. K. Lee

L. G. Loden

M. E. Manning

J. C. Mathis

R. L. McDougal

C. Metz

C. O. Miller III

A. G. Mitchell

M. E. Mitchell/T. P. A. Perry

R. W. Mitchell

J. S. Parrott

R. D. Parsons

M. O. Phillips

J. J. Plante

P. D. Psihogios

L. L. Radcliffe/J. L. Sager, DOE-ORO
W. J. Redmond

G. A. Renfroe

T. Scott

R. W. Sellars

B. E. Skaggs

R. R. Smith

R. J. Spence/B. C. DeMonia, DOE-ORO

J. C. Stutts

E. J. Tobler

L. L. Triplett

E. Turnbill

J. L. Villarreal

T. R. Vincent

D. R. Walker

G. H. Winebarger/J. T. Foust

C. F. Wisener

W. B. Woods

R. C. Wright

Y-12 Central Files

File - EMD - RC 


\section{SECTION H \\ PERSONNEL TRAINING}

The information contained in this section of the permit application outlines the training programs for personnel at the Y-12 Plant who are directly involved with the operation of hazardous waste management units in accordance with the requirements of 40 CFR Parts 264 and 270, and Rules 1200-1-11-.07 and -.06 of the Rules Governing Hazardous Waste Management in Tennessee.

\section{H-1 OUTLINE OF TRAINING PROGRAM}

H-1a Job Titles and Tasks

Responsibility involving compliance with RCRA resides with the responsible department head and/or supervisor for each facility in the Waste Management Division, who oversees all aspects of the management of wastes in Buildings 9201-4, 9720-9, 9720-25, 9720-31, 9720-58, OD-8, and CWSA. The Staff Engineer for each facility provides technical support and project management related to the physical aspects and compliance requirements of the facility. Sampling, verification of waste streams, documentation, and quality control regarding storage and management procedures is the responsibility of the WSSO I Department. Actual handling of wastes and movement of wastes into and out of the building is performed by trained laborers working at the specific facilities. The job titles, tasks, and task descriptions for each position are presented in Appendix H-2. The minimum information provided in the job descriptions are as follows:

- Position title,

- Basic function of position,

- Major environmental duties and responsibilities, and

- Formal education required.

\section{H-1b Training Content, Frequency, and Techniques}

The workers receive documented performance-based training and job-specific training. Training techniques are patterned after the performance-based training and include, but are not limited to, classroom, on-the-job, and required reading materials. The Y-12 Plant Administrative Procedures exist which delineate training responsibilities and structures within the Y-12 Plant. All personnel who work at Buildings 9201-4, 9720-9, 9720-25, 9720-31, 9720-58, OD-8, and CWSA receive initial and annual refresher OSHA Hazard Communications Training, initial OSHA/SARA 24-hour training, 8-hour refresher 
OSHA/SARA training, annual respirator training, annual RCRA training, and biennial radiation protection and criticality training. The frequency of the course training is presented in Appendix H-3. Specific modules used are listed in the following paragraph.

Basic Training: The basic training program includes, but is not limited to, the following subject areas:

- 24-Hour OSHA/SARA Training: All personnel working at Buildings 9201-4, 9720-9, 9720-25, 9720-31, 9720-58, OD-8, and CWSA are sent to the 24-Hour Hazardous Waste Management Training and an annual 8-hour refresher as required by OSHA, per SARA. Supervisors receive an additional 8 hours of training as required.

- Hazard Communications Training: All personnel received the initial Hazard Communications training. Specific modules listed below are included as part of this training as applicable.

- Compliance Awareness: This module presents a general overview of the environmental regulations that impact the work of the Y-12 Plant facility.

- RCRA Annual Training: This module presents the basic requirements for compliance with RCRA and includes proper hazardous waste management and documentation. This module is updated annually as needed and presented to the applicable personnel.

Specifically, the following subjects will be covered in the annual RCRA refresher training:

1. All hazardous wastes currently being handled at the facilities, noting any changes in waste type, volume, source, characteristics, or location that have occurred during the past year.

2. The status of storage and operating conditions and procedures, noting any areas where there are problems or the potential for problems. Employees participate in developing effective solutions. 
3. The requirements contained in the RCRA permit of the facilities, noting any changes that have occurred during the past year. Areas where maintenance of compliance is a problem are identified and discussed, and effective solutions are sought.

4. Incidents that have occurred in the past year that warranted use of contingency plans and/or emergency action. This review focuses on the cause of the incident and identification of steps to be taken to prevent or to ensure better handling of such events in the future.

- Hazard Communication/Toxicology: This training program is designed to inform employees of the potential harmful effects of chemicals. The program examines the nature of toxic effects, the dose/response relationship, routes of entry of toxic substances, and various acute and chronic effects.

- Hazard Communication/Chemical Safety: Training will outline an overview of the health and safety hazards that chemicals pose and good chemical safety practices, thus motivating workers to take precautions to protect themselves. It describes the different forms of chemicals, routes of exposure, common signs and symptoms of exposure, and the effects of exposure. Materials described include carcinogens, corrosives, toxics, irritants, sensitizers, and chemicals that have target organ effects. The importance of using labels and material safety data sheets, as well as the measuring and monitoring of the job environment, will be detailed.

- Corrosives: This module presents the hazards that corrosives pose, describes the exposure symptoms, discusses containers and storage, outlines personal safety precautions, and explains what to do in the event of an emergency.

- Solvents: This module concentrates on the health and safety precautions when working with solvents.

- Poisons: This module discusses the different forms of poisons, safe handling procedures, and proper storage. It emphasizes personal protection as well as emergency methods and first aid. This module places emphasis on compressed gases because of their widespread use and the physical hazards that they pose. 
- Gases: This module discusses proper moving and storing of gas cylinders, the effect of different gases on the body, personal protection, what to do in an emergency, and special instructions for emergency and rescue personnel.

- Oxidizers: This module addresses the proper safety and health measures when handling oxidizers.

- Explosives: This module stresses the importance of using the correct tools and equipment, maintaining a proper work environment, checking labels and material safety data sheets, and checking process sheets for all operations or processes which involve potential explosion hazards.

- Carcinogens: This module describes protection which is dependent upon a system of safeguards--personal protective gear, engineering controls, administrative controls, or a combination of the three. It covers each control in addition to routes of entry, industrial hygiene, labels, warning signs and posters, material safety data sheets, and monitoring.

- Protective Clothing: In dealing with chemical hazards, the most important line of defense against personal contact and contamination is protective clothing. Training details the correct methods of selecting and wearing protective equipment including gloves, aprons, goggles, etc., as required.

- Respiratory Protection: In order to protect the respiratory tract against irritating and poisonous gases, fumes, smoke, and dusts, the worker must be knowledgeable in the proper use of the respirator. Information on the various types of respirators, the requirements to ensure a good fit, and emergency actions are presented in this module. Workers will also be trained on the specific respiratory hazards, requirements, and issue procedures for their specific job.

- Radiological Protection: Informs workers about the hazards associated with radiation exposure and presents methods of controlling dose levels to within acceptable limits. Training will be presented in the Radiation Control module.

- Criticality Safety: The concepts and required safety controls related to criticality safety are explained in this module. 
Job Qualification: Currently, on-the-job training (OJT) of technicians and laborers is conducted under the direct supervision of the waste management supervisor. This training includes operational and job safety requirements. However, in order to improve, formalize, and document the required OJT, the job task analysis for each of these facilities has been completed. Based on this job task analysis and specific safety requirements for each facility, lesson plans for OJT will be completed and will be performed by supervisors who have successfully completed the Supervisors On-The-Job Training course. Comprehensive written exams will be required once a participant has completed training associated with his/her responsibilities per the operating procedures. In addition to the written examination, the technician or laborer will be required to demonstrate his proficiency in the required tasks. Failure of the test requires the technician/laborer to undergo further training. Though the lesson plans will be specifically directed at the proper operation of the facilities, general topics to be included as applicable are: (1) conducting routine checks and inspections, (2) job-specific personal protective equipment training, and (3) maintaining records and data. Annual refresher training will be provided as applicable and necessary.

Emergency Preparedness: The training program is designed to ensure that personnel not only handle hazardous wastes in a safe manner, but also properly respond to emergency situations. The program trains hazardous waste handling/management personnel to maintain compliance under both normal operating conditions and emergency conditions.

Training elements addressing non-routine and emergency situations (unscheduled shutdowns and startups related to storms, power outages, fires, explosions, spills) as applicable include:

1. Contingency Plan requirements and implementation,

2. Procedures for locating, using, inspecting, repairing, and replacing facility emergency and monitoring equipment, including personal safety, fire control, and spill control equipment and alarm and communication systems,

3. Response to fires or explosions,

4. Response to incidents and procedures for containing, controlling, and mitigating spills, and any surface or groundwater contamination, 
5. Shutdown of operations, power failure procedures and any other emergency operating procedures, and

6. Procedures for evacuation of nearby areas.

In addition to the hazardous waste management personnel, a plant emergency squad is on duty for response to all fires and other general plant emergencies. This emergency squad is trained with classroom training methods and fire drills. The classroom training is required for introductory training and as an annual review for each member of the squad.

Training records are being maintained by personnel in the Y-12 Training Records Center. The Training Management System (TMS), an electronic data base, is used by training personnel to track the status of training.

\section{H-1c Training Director}

The personnel training program is directed by a Waste Management Divisional Training Manager who is familiar with plant operations, facility design, and operating procedures. This manager is required to have a minimum of a bachelors degree or equivalent education and/or experience, process knowledge, and demonstrated knowledge of instructional system design and technology. The Training Coordinators who perform the training must be reviewed and approved by the Training Manager. The qualifications required for these positions are included in the job descriptions found in Appendix H-2.

\section{H-1d Relevance of Training to Job Position}

The training program is tiered in some areas to provide training to personnel at levels that are relevant to their positions within the plant. For example, the personnel responsible for the completion of manifests receive additional training in recordkeeping required for compliance, whereas laborers do not. Laborers are more specifically trained to maintain proper and safe operating procedures and to respond effectively in the event of a spill or other emergency. The completed job task analysis for each of these three facilities will be utilized to update and improve the existing training as applicable in order to continue to make the training more relevant to the specific job position being trained. 


\section{H-2 IMPLEMENTATION AND DOCUMENTATION OF TRAINING PROGRAM}

\section{H-2a Implementation}

The Waste Management Organization Training Manager has been fully trained at the time of this submittal. All personnel must complete this training within six months from their date of assignment to a hazardous waste management job. No employee assigned to perform a hazardous waste management job works unsupervised prior to completion of the training program. The six month training completion period applies to all of the compliance related training. The OJT program is administered on a continual basis.

H-2b Recordkeeping

Please see Section J, Recordkeeping, for information. 


\section{SECTION I}

\section{CLOSURE PLAN, POST CLOSURE PLAN, AND FINANCIAL REQUIREMENTS}

\section{I-1 CLOSURE PLANS}

Buildings 9201-4, 9720-9, 9720-25, 9720-31, 9720-58, OD-8, and CWSA, located at the Oak Ridge Y-12 Plant, will be considered active units and operated in compliance with all applicable requirements for active units until closure activities are initiated.

This closure plan has been prepared for these units which are used for container storage of various hazardous and mixed wastes. Complete facility descriptions are provided in Section B, Facility Description.

The Oak Ridge Y-12 Plant is located in Anderson County and is co-operated and managed by personnel from Martin Marietta Energy Systems Inc., for the DOE. The EPA identification number for the Y-12 Plant is TN3 89-009-0001.

If changes occur in the operating plans or unit design that may affect the closure plan, it will be amended. Amendments to the closure plan may also be necessary if new technologies are developed, changes in operating requirements or contingencies, and changes of the landuse patterns around the site.

\section{I-1a Closure Performance Standard}

This closure plan is designed to ensure that, after closure, the facility will not require further maintenance and controls; to minimize or eliminate threats to human health or the environment; and to avoid the escape of hazardous wastes, hazardous waste constituents, leachate, contaminated rainfall, or waste decomposition products to ground or surface waters, or to the atmosphere.

This standard will be accomplished through the removal of all RCRA hazardous wastes stored in containers at the facility. These wastes will be transferred to an appropriately permitted facility for storage or treatment.

The following sections discuss, in detail, efforts to be made at the facilities to satisfy closure requirements. 


\title{
I-1b Partial Closure and Final Closure Activities
}

Partial closure for the units in this application is not anticipated. If it becomes necessary to partially close any of the units described in this permit application, the procedures described in Section I-1e, Closure Procedures, will be followed for the type of unit being closed.

Final closure of the units will consist of the removal of all hazardous wastes and hazardous waste residues remaining at the unit and the decontamination or disposal of the containment structure components and auxiliary equipment. All hazardous wastes and residues will be containerized and transported to an approved RCRA permitted facility for storage, treatment, or disposal.

\section{I-1c Maximum Waste Inventory}

The following table represents the maximum waste inventory that will be in storage at the units:

\begin{tabular}{cc} 
Unit & $\begin{array}{c}\text { Maximum Waste Inventory } \\
\text { (gallons) }\end{array}$ \\
\hline $9201-4$ & 17,160 \\
$9720-9$ & 393,440 \\
$9720-25$ & 32,465 \\
$9720-31$ & 46,000 \\
$9720-58$ & 153,310 \\
OD-8 & 106,720 \\
CWSA & 810,000 \\
\hline
\end{tabular}

\begin{abstract}
All hazardous wastes remaining in these units at the time of closure will be transferred to a permitted facility for storage, treatment, or disposal. The procedures for removing, transporting, and/or storing the remaining hazardous waste and decontamination debris from the units are described in Section I-1e(1).
\end{abstract}


Figure $\mathrm{I}-1$

Schedule of Closure

Building 9201-4 Container Storage Area

\begin{tabular}{|c|c|c|c|c|c|c|c|c|c|c|c|c|c|c|c|c|c|c|c|c|c|c|}
\hline \multirow{2}{*}{ Description of Work } & \multicolumn{22}{|c|}{ Days } \\
\hline & $\star$ & 10 & 20 & 30 & 40 & 50 & 60 & 70 & 80 & 90 & 100 & 110 & 120 & 130 & 140 & 150 & 160 & 170 & 180 & 190 & & 210 \\
\hline 1. Notify Regulatory Authority & & & $\vdots$ & & & & & & $\vdots$ & : & ? & $\vdots$ & & & $\vdots$ & & $\vdots$ & & & & & \\
\hline 2. Initiate Closure & & & $\vdots$ & & & & & & & & : & $\vdots$ & & & & $\vdots$ & $\vdots$ & & & $\vdots$ & $\vdots$ & $\vdots$ \\
\hline 3. Mobilization & & & $\vdots$ & & & & & & $\vdots$ & & & $\vdots$ & & $\vdots$ & $\vdots$ & & $\vdots$ & & $\vdots$ & $\vdots$ & & $\vdots$ \\
\hline 4. Remove Tank/Equipment Contents & & & $\vdots$ & & & & & & $\vdots$ & & & $\vdots$ & & & $\vdots$ & $\vdots$ & $\vdots$ & & & $\vdots$ & & \\
\hline 5. Decontaminate Unit Structure, Equipment & & & $\vdots$ & & & & & & : & & & & & & $\vdots$ & & $\vdots$ & & & $\vdots$ & $\vdots$ & \\
\hline $\begin{array}{l}\text { 6. Sample and Analyze Decontamination } \\
\text { Solution }\end{array}$ & & & $\vdots$ & & & & & & & & & & & & & & & & & $\vdots$ & & \\
\hline 7. Additional Decontamination (If Necessary) & & & $\vdots$ & & & & & & & & & $\vdots$ & & & & & & & & : & & \\
\hline 8. Initial Assessment of Surface Soil & & & & & & & & & & & & $\vdots$ & & & & & $\vdots$ & & & $\vdots$ & & \\
\hline $\begin{array}{l}\text { 9. Secondary Assessment of Soil } \\
\text { (If Necessary) }\end{array}$ & & & $\vdots$ & & & & & & $\vdots$ & $\vdots$ & & $\therefore$ & & & a & & $\vdots$ & & & $:$ & & \\
\hline 10 Independent Engineer Inspections & & & & & & & & & 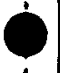 & $\vdots$ & & & & & & : & $\vdots$ & & & & $\vdots$ & \\
\hline 11. Closure Certification & & & & & & & & & & $\vdots$ & & & & & & & & & & & & \\
\hline 12. Notify Regulatory Authority & & & & & & & & & & & & & & & & & & & & & & \\
\hline
\end{tabular}

$\star$ Notification will be submitted prior to start of closure.

1-3

Y.GA $94.792 \mathrm{sh}$ 


\section{Figure 1-2 \\ Schedule of Closure Building 9720-9 Storage Unit}

\begin{tabular}{|c|c|c|c|c|c|c|c|c|c|c|c|c|c|c|c|c|c|c|c|c|c|c|}
\hline \multirow{2}{*}{ Description of Work } & \multicolumn{22}{|c|}{ Days } \\
\hline & $\star$ & 10 & 20 & 30 & 40 & 50 & 60 & 70 & 80 & 90 & 100 & 10 & 120 & 130 & 140 & 150 & 160 & 170 & $180 \mid 1$ & 190 & 200 & 210 \\
\hline 1. Notify Regulatory Authority & & & & : & : & & : & & : & & & ? & & & & & & & & $\vdots$ & & $\vdots$ \\
\hline 2. Initiate Closure & & & & $:$ & & & $\vdots$ & & & & & & & & & & $\vdots$ & $\vdots$ & & $\vdots$ & $\vdots$ & $\vdots$ \\
\hline 3. Mobilization & & & & $\vdots$ & & $:$ & 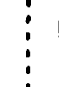 & ! & $\vdots$ & & & $\vdots$ & & & $\vdots$ & $\vdots$ & $\vdots$ & $\vdots$ & & $\vdots$ & & $\vdots$ \\
\hline 4. Remove Tank/Equipment Contents & & & & & & & $\vdots$ & & & & & & & & $\vdots$ & 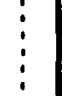 & & $\vdots$ & & $\vdots$ & & $\vdots$ \\
\hline 5. Decontaminate Unit Structure, Equipment & & & & & & & & & & & & & & & & & & $\vdots$ & & $\vdots$ & & \\
\hline $\begin{array}{l}\text { 6. Sample and Analyze Decontamination } \\
\text { Solution }\end{array}$ & & & & & & & & & & & & & & & & & & $\vdots$ & & $\vdots$ & & $\vdots$ \\
\hline 7. Additional Decontamination (If Necessary) & & & & & & & $\vdots$ & $\vdots$ & & & & & & & & & & & & & $\vdots$ & $\vdots$ \\
\hline 8. Initial Assessment of Surface Soil & & & & & & & ( & & & & & & & & 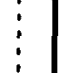 & $\vdots$ & & $\vdots$ & & : & & $\vdots$ \\
\hline $\begin{array}{l}\text { 9. Secondary Assessment of Soil } \\
\text { (If Necessary) }\end{array}$ & & & 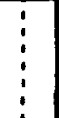 & : & : & & $\vdots$ & & $\vdots$ & & & & & & 3 & $\vdots$ & & $\vdots$ & & $\vdots$ & $\vdots$ & $\vdots$ \\
\hline 10 Independent Engineer Inspections & & & & & & & & & & & & & & & & 列 & & & & & & $\vdots$ \\
\hline 11. Closure Certification & & & & & & & $\vdots$ & $\vdots$ & $\vdots$ & ! & & & & $\vdots$ & : & & & & & & & \\
\hline 12. Notify Regulatory Authority & & & & & & & & & & & & & & & & & & & & & & \\
\hline
\end{tabular}

$\star$ Notification will be submitted prior to start of closure. Y.GA 94-79? sh 
Figure I-3

Schedule of Closure

Classified Container Storage Unit, Building 9720-25

\begin{tabular}{|c|c|c|c|c|c|c|c|c|c|c|c|c|c|c|c|c|c|c|c|c|c|c|}
\hline \multirow{2}{*}{ Description of Work } & \multicolumn{22}{|c|}{ Days } \\
\hline & $\star$ & 10 & 20 & 30 & 40 & 50 & 60 & 70 & 80 & 90 & 100 & $10 \mid$ & $20 \mid 1$ & 130 & 140 & 150 & 160 & 170 & 180 & 190 & 2002 & 210 \\
\hline 1. Notify Regulatory Authority & & & & & & & & & & & & & & & $\vdots$ & $\vdots$ & $\vdots$ & & : & & & \\
\hline 2. Initiate Closure & & & & & $\vdots$ & & & & & & & & & & $\vdots$ & $\vdots$ & $\vdots$ & & & & & $\vdots$ \\
\hline 3. Mobilization & & & & & $\vdots$ & & $\vdots$ & & & & & & & & $\vdots$ & $\vdots$ & $\vdots$ & & & & $\vdots$ & $\vdots$ \\
\hline 4. Remove Tank/Equipment Contents & & & 正 & 敀 & $\vdots$ & & & & & & & & & & $\vdots$ & $\vdots$ & $\vdots$ & $\vdots$ & $\vdots$ & & & $\vdots$ \\
\hline 5. Decontaminate Unit Structure, Equipment & & & & & & & & & & & & & & & & $\vdots$ & & & & & $\vdots$ & \\
\hline $\begin{array}{l}\text { 6. Sample and Analyze Decontamination } \\
\text { Solution }\end{array}$ & & & & & & & & & & & & & & & : & $\vdots$ & & & & $\vdots$ & & $\vdots$ \\
\hline 7. Additional Decontamination (If Necessary) & & & & & $\vdots$ & & $:$ & & & & & & & & i & $\frac{1}{3 x+2}$ & $\frac{1}{i}$ & & & $\vdots$ & & $\vdots$ \\
\hline 8. Initial Assessment of Surface Soil & & & & & $\therefore$ & U & & & & & & & & & & & & & & & & \\
\hline $\begin{array}{l}\text { 9. Secondary Assessment of Soil } \\
\text { (If Necessary) }\end{array}$ & & & & & : & $\vdots$ & & & & & & & & & & & & & & & & $\vdots$ \\
\hline 10 Independent Engineer Inspections & & & & & & & & & $\dot{4}$ & & & & & & & & & & & & & $\vdots$ \\
\hline 11. Closure Certification & & & & & & & & & & & & & & & & & & & & & $\vdots$ & \\
\hline 12. Notify Regulatory Authority & & & & & & & & & & & & & & & & & & & & $\vdots$ & 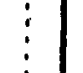 & \\
\hline
\end{tabular}

$\star$ Notification will be submitted prior to start of closure. 


\section{Figure 1-4 \\ Schedule of Closure \\ RCRA and Mixed Waste Storage and Staging, Building 9720-31}

\begin{tabular}{|c|c|c|c|c|c|c|c|c|c|c|c|c|c|c|c|c|c|c|c|c|c|}
\hline \multirow{2}{*}{ Description of Work } & \multicolumn{21}{|c|}{ Days } \\
\hline & $\star$ & 10 & 20 & 30 & 40 & 50 & 60 & 70 & 80 & 90 & 100 & 110 & $120 \mid 1$ & 1301. & $140 \mid 1$ & $150 \mid 1$ & 1601 & $170 \mid 180$ & 30190 & 200 & 210 \\
\hline 1. Notify Regulatory Authority & & & & $\vdots$ & & & & & : & ; & $\vdots$ & & & & & & & & & & \\
\hline 2. Initiate Closure & & & $\vdots$ & & & & & $\vdots$ & & $\vdots$ & & & & & & & & & & & \\
\hline 3. Mobilization & & & $\vdots$ & $\vdots$ & $\vdots$ & & : & $\vdots$ & $\vdots$ & 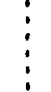 & & & & & & & $\vdots$ & & & & \\
\hline 4. Remove Tank/Equipment Contents & & & & & & & & & & 㷇 & & & & & & & & & & & \\
\hline 5. Decontaminate Unit Structure, Equipment & & & $\vdots$ & & & & & & & & & & & & & $\vdots$ & $\vdots$ & $\vdots$ & & & \\
\hline $\begin{array}{l}\text { 6. Sample and Analyze Decontamination } \\
\text { Solution }\end{array}$ & & ( & $\vdots$ & & & & & & & & & & & & & & & & & & \\
\hline 7. Additional Decontamination (If Necessary) & & & $\vdots$ & & & & & $\vdots$ & & & & & & & & & & & & $\vdots$ & \\
\hline 8. Initial Assessment of Surface Soil & & & & & & & & & & & & & & & & & & & & & \\
\hline $\begin{array}{l}\text { 9. Secondary Assessment of Soil } \\
\text { (If Necessary) }\end{array}$ & & $\vdots$ & $\vdots$ & $\vdots$ & $\vdots$ & $\vdots$ & : & $\vdots$ & $\vdots$ & $\vdots$ & : & & & & & & $\vdots$ & & & $\vdots$ & \\
\hline 10 Independent Engineer Inspections & & & & & & & & & is & & & & & & & & & & & & \\
\hline 11. Closure Certification & & & & & & & & & & & & & & & & & & & $\vdots$ & & \\
\hline 12. Notify Regulatory Authority & & & & $\vdots$ & & & & $\vdots$ & $\vdots$ & & & & & & & & & & & & \\
\hline
\end{tabular}

$\star$ Notification will be submitted prior to start of closure. 


\section{Figure $1-5$ \\ Schedule of Closure \\ RCRA and PCB Container Storage Area, Building 9720-58}

\begin{tabular}{|c|c|c|c|c|c|c|c|c|c|c|c|c|c|c|c|c|c|}
\hline \multirow[b]{2}{*}{ Description of Wor } & \multicolumn{17}{|c|}{ Days } \\
\hline & $\star$ & 10 & 20 & & 0 & $0 \mid 6 c$ & 7 & 80 & 90 & & & & 140 & \begin{tabular}{|l|l|}
150 & 160 \\
\end{tabular} & \begin{tabular}{l|l|l|l|l|}
0 & 170 & 180 & 190 \\
\end{tabular} & 20021 & 210 \\
\hline 1. Notity Regulatory Authority & & & & & & & & & & & & & & & & & \\
\hline 2. Initiate Closure & & & & & & & & & & & & & & & & & \\
\hline 3. Mobilization & & & & & & & & & & & & & & & & & \\
\hline 4. Remove Tank/Equipment $\mathrm{C}$ & & & & & & & & & & & & & & & & & \\
\hline 5. Decontaminate Unit Structu & & & & & & & & & & & & & & & & & \\
\hline $\begin{array}{l}\text { 6. Sample and Analyze Decon } \\
\text { Solution }\end{array}$ & & & & & & & & & & & & & & & & & \\
\hline 7. Additional Decontamination & & & & & & & & & & & & & is & is & $\frac{1}{4}$ & & \\
\hline 8. Initial Assessment of Surfac & & & & & & & & & & & & & & & & & \\
\hline $\begin{array}{l}\text { 9. Secondary Assessment of } S \\
\text { (If Necessary) }\end{array}$ & & & & & & & & & & & & & $j$ & & & & \\
\hline 10 Independent Engineer Inspe & & & & & & & & 9 & & & & & & & & & \\
\hline 11. Closure Certification & & & & & & & & & & & & & & & a & & \\
\hline 12. Notity Regulatory Authority & & & & & & & & & & & & & & & & & \\
\hline
\end{tabular}

$\star$ Nollfication will be submitted prior to start of closure. 


\section{Figure I-6 Schedule of Closure \\ Building 9811-1 RCRA Container Storage Unit (OD-8)}

\begin{tabular}{|c|c|c|c|c|c|c|c|c|c|c|c|c|c|c|c|c|c|c|c|c|c|c|}
\hline \multirow{2}{*}{ Description of Work } & \multicolumn{22}{|c|}{ Days } \\
\hline & $\star$ & 10 & 20 & 30 & 40 & 50 & 60 & 70 & 80 & 90 & 100 & 10 & 20 & 130 & 140 & 150 & 160 & $170 \mid 1$ & 180 & 190 & 200 & 210 \\
\hline 1. Notify Regulatory Authority & & & & & & & $\vdots$ & $\vdots$ & & & & $\vdots$ & 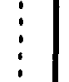 & & & $\vdots$ & $\vdots$ & & & & $\vdots$ & \\
\hline 2. Initiate Closure & & & & & & 0 & $\vdots$ & & & & & $\vdots$ & & & $\vdots$ & $\vdots$ & & $\vdots$ & & & $\vdots$ & \\
\hline 3. Mobilization & & & & & & $\vdots$ & $\vdots$ & $\vdots$ & & & & $\vdots$ & & & $\vdots$ & $\vdots$ & $\vdots$ & $\vdots$ & & & $\vdots$ & \\
\hline 4. Remove Tank/Equipment Contents & & & $\therefore$ & . & : & 8 & & $\vdots$ & & & & $\vdots$ & & & & $\vdots$ & & & & $\vdots$ & $\vdots$ & \\
\hline 5. Decontaminate Unit Structure, Equipment & & & & & & & & & & & & & & & & & & & & & $\vdots$ & \\
\hline $\begin{array}{l}\text { 6. Sample and Analyze Decontamination } \\
\text { Solution }\end{array}$ & & & $\vdots$ & & & $\vdots$ & $\vdots$ & 8 & & & & & & & & : & & & & & $\vdots$ & \\
\hline 7. Addilional Decontamination (If Necessary) & & & $\vdots$ & & & $\vdots$ & $\vdots$ & $\vdots$ & & & & $\vdots$ & & & & 崭 & & & & & $\vdots$ & \\
\hline 8. Initial Assessment of Surface Soil & & & & & & & . & & & & & $:$ & & & & & $\vdots$ & & & & & \\
\hline $\begin{array}{l}\text { 9. Secondary Assessment of Soil } \\
\text { (II Necessary) }\end{array}$ & & & : & $\vdots$ & : & : & $\vdots$ & $\vdots$ & 珢 & & & & & & is & & & & & & : & \\
\hline 10 Independent Engineer Inspections & & & & & & & & & i & & & & & & $\vdots$ & & & & & & : & \\
\hline 11. Closure Certification & & & & & & & & & & & & & & & & & & & & & & \\
\hline 12. Notify Regulatory Authority & & & & & & & & & & & & & & $\vdots$ & & & & & & & & \\
\hline
\end{tabular}

$\star$ Notification will be submitted prior to start of closure.

Y.GA 94.700 eh 
Figure $1-7$

Schedule of Closure

Containerized Waste Storage Area (CWSA)

\begin{tabular}{|c|c|c|c|c|c|c|c|c|c|c|c|c|c|c|c|c|c|c|c|c|c|c|}
\hline \multirow{2}{*}{ Description of Work } & \multicolumn{22}{|c|}{ Days } \\
\hline & $\star$ & 10 & 20 & 30 & 40 & 50 & 60 & 70 & 80 & 90 & 100 & 110 & 120 & 130 & 140 & 150 & 160 & $170 \mid$ & $180 \mid 1$ & 190 & 200 & 210 \\
\hline 1. Notify Regulatory Authority & & & $\vdots$ & : & & & & & & & 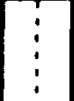 & $\vdots$ & & & & & $\vdots$ & $\vdots$ & & $\vdots$ & $\vdots$ & \\
\hline 2. Initiate Closure & & & & & & & & & & & 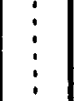 & $\vdots$ & & & & $\vdots$ & $\vdots$ & $\vdots$ & & & & \\
\hline 3. Mobilization & & & & & & & & & & & 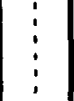 & 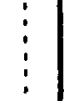 & & & & $\vdots$ & $\begin{array}{l}\vdots \\
\vdots\end{array}$ & $\begin{array}{l}\vdots \\
\vdots\end{array}$ & & : & $\vdots$ & \\
\hline 4. Remove Tank/Equipment Contents & & & & & & & & & & & $\vdots$ & $\vdots$ & & & & $\vdots$ & $\vdots$ & $\vdots$ & & $\vdots$ & & \\
\hline 5. Decontaminate Unit Structure, Equipment & & & & & & & & & & & & & & & & & & $\vdots$ & & & & \\
\hline $\begin{array}{l}\text { 6. Sample and Analyze Decontamination } \\
\text { Solution }\end{array}$ & & & & & & & & & & & 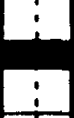 & $\vdots$ & & & & & $\vdots$ & $\vdots$ & & $\vdots$ & & $\vdots$ \\
\hline 7. Additional Decontamination (If Necessary) & & & & & & & & & & & & & & & & & & 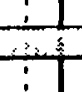 & $\div$ & & & \\
\hline 8. Initial Assessment of Surface Soil & & & & & & & & & & ${ }^{\circ}$ & & $\vdots$ & & & & $\vdots$ & & $\vdots$ & & & & 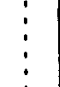 \\
\hline $\begin{array}{l}\text { 9. Secondary Assessment of Soil } \\
\text { (II Necessary) }\end{array}$ & & & $\vdots$ & & & & 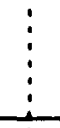 & & & & & 2 & & & ? & ! & & $\vdots$ & & & & $\vdots$ \\
\hline 10 Independent Engineer Inspections & & & & & & & & & & & & & & & & & & & & & & \\
\hline 11. Closure Certification & & & & & & & & & & & & & & & & & & & & & & \\
\hline 12. Notify Regulatory Authority & & & & & & & & & & & & & & & & : & & & & & & \\
\hline
\end{tabular}

$\star$ Notification will be submitted prior to start of closure. Y.r,A 04.79? ath 


\section{I-1d Schedule for Closure}

The proposed schedule for final closure for Buildings 9201-4, 9720-9, 9720-25, 9720-31, 9720-58, OD-8, and CWSA is 2020. The proposed closure schedule is included in Figures I-1 through I-7.

\section{I-1d(1) Time Allowed For Closure}

All hazardous wastes will be removed from the unit and will be treated or disposed of either on-site or off-site within 90 days from receipt of the final volume of hazardous waste. Closure activities will be completed within 180 days from the receipt of the final volume of hazardous waste. The actual times for each step of the closure activities is shown in Figures I-1 through I-7.

\section{I-1d(1)(a) Extensions for Closure Time}

It is not anticipated that an extension for time for closure activities for the units will be required. However, if closure cannot be completed within the specified time, a request for an extension of closure time will be submitted to the Commissioner in accordance with Tennessee Rule 1200-1-11-.06(7)(d).

\section{I-1e Closure Procedures}

Before closure activities begin, the units will be surveyed by the Y-12 Health Physics Organization personnel and a safety plan will be prepared based on the site conditions. The plan will identify radiological and chemical hazards as well as controls to reduce worker risk.

\section{I-1e(1) Inventory Removal, Disposal and Decontamination of Equipment}

Closure activities for the units in this permit application will be performed in a similar manner. All hazardous wastes present at the time of closure will be removed and transferred, via a tanker truck, to a permitted storage area, treated, or shipped off-site.

Wipe samples will be collected to verify if the decontamination efforts are complete. A wiping material (cotton swab or filter paper) will be used and random samples taken at the units. The wipe samples will be analyzed for the hazardous constituents which were managed at the unit using an EPA approved analytical procedure (e.g., TCLP).

If residual contamination exceeds the allowable limits, an additional washing will be performed. Areas that persist in retaining contamination after this washing will be sand 
blasted or physically removed from the area. The debris will be collected and managed as hazardous waste.

The equipment that may be used for the closure activities includes, but is not limited to, cleaning brushes, adsorbents, solvents, soap and alkaline cleaners, squeegees, pressure sprayers, water, water recovery drums, concrete removal equipment, forklift, plastic sheeting, and pumps. Equipment will be rinsed, if applicable, to remove any residual contamination that may have adhered to the cleaning apparatus. The rinse water will be collected, sampled, and managed accordingly. Debris from closure will be collected, sampled, and analyzed for hazardous contituents. If the tests indicate that the debris is hazardous waste, then it will be treated as such. If the debris is not deemed hazardous waste, it will be disposed of accordingly.

\section{Soil Assessment}

If major cracks are discovered in the containment area at the time of closure, soil samples will be taken directly beneath the cracks. Corings will be made through the major cracks (excludes hairline fractures) if present, and a split-spoon sampler will be used to obtain a sample beneath the containment structure. It is very likely that major cracks will not be present since inspections and annual leak testing are performed. In this event, random soil samples will be taken from exposed areas adjacent to the units and analyzed for hazardous constituents that were managed at the unit. Soil cuttings and debris will be collected and stored at a permitted facility pending analytical results. If the analytical results exceed the desirable limits, the soil will be excavated, contained, and managed as hazardous waste. Decontamination of equipment used for soil sampling and soil excavation will be performed in the same manner described above.

Final closure of the units will be certified by the Department of Energy and an independent registered Professional Engineer.

\section{I-1e(2) Closure of Disposal Units}

Not applicable. Requirements of this section do not apply to the units in this permit application.

\section{I-1e(3) Closure of Containers}

All containers of hazardous waste will be transferred to an approved facility for storage or treatment. Equipment to be used will be a, but not limited to, forklift, hand pallet jack, 
and/or hand dolly. Closure activities for the container storage areas will be performed as part of the overall closure activities of the units and similar procedures described in Section I-1e, Closure Procedures.

\section{I-1e(4) Closure of Tanks}

Requirements of this section do not apply to the units in this permit application.

\section{I-1e(5) Closure of Waste Piles}

Requirements of this section do not apply to the units in this permit application.

\section{I-1e(6) Closure of Surface Impoundments}

Requirements of this section do not apply to the units in this permit application.

\section{I-1e(7) Closure of Incinerators}

Requirements of this section do not apply to the units in this permit application.

\section{I-1e(8) Closure of Landfills}

Requirements of this section do not apply to the units in this permit application.

\section{I-1e(9) Closure of Land Treatment Units}

Requirements of this section do not apply to the units in this permit application.

I-1e(10) Closure of Miscellaneous Units

Requirements of this section do not apply to the units in this permit application.

\section{I-2 POST-CLOSURE PLAN}

Hazardous waste or hazardous waste residues will not remain at the units after closure; therefore, this section is not required.

\section{I-2a Inspection Plan}

Hazardous waste or hazardous waste residues will not remain at the units after closure; therefore, this section is not required.

\section{I-2b Monitoring Plan}

Hazardous waste or hazardous waste residues will not remain at the units after closure; therefore, this section is not required. 


\section{I-2c Maintenance Plan}

Hazardous waste or hazardous waste residues will not remain at the units after closure; therefore, this section is not required.

\section{I-2d Land Treatment}

Hazardous waste or hazardous waste residues will not remain at the units after closure; therefore, this section is not required.

\section{I-2e Post-Closure Care for Miscellaneous Units}

Hazardous waste or hazardous waste residues will not remain at the units after closure; therefore, this section is not required.

\section{I-2f Post-Closure Security}

Hazardous waste or hazardous waste residues will not remain at the units after closure; therefore, this section is not required.

\section{I-2g Post-Closure Contact}

Hazardous waste or hazardous waste residues will not remain at the units after closure; therefore, this section is not required.

\section{I-3 CERTIFICATION AND NOTICES REQUIRED FOR CLOSURES}

\section{I-3a Certification of Closure}

Within 60 days of completing final closure of the units, DOE will submit, in writing, a closure certification to the Commissioner. The certification will verify that the units were closed in accordance with the specifications of the approved closure plan. The certification will be signed by DOE and an independent registered professional engineer.

\section{I-3b Survey Plat}

A survey plat is not required for the clean closure of a container storage area.

\section{I-3c Notice to Local Land Authority}

This section is not required for the clean closure of a container storage area.

\section{1-3d Post-Closure Certification}

This section is not required for the clean closure of a container storage area. 


\section{I-3e Notice in Deed to Property}

This section is not required for the clean closure of a container storage area.

\section{I-4 CLOSURE COST ESTIMATE}

Under 40 CFR Part 264.140(c), federal facilities are exempt from the requirements of this section.

\section{I-5 FINANCIAL ASSURANCE MECHANISM FOR CLOSURE}

Under 40 CFR Part 264.140(c), federal facilities are exempt from the requirements of this section.

\section{I-6 POST-CLOSURE COST ESTIMATE}

Under 40 CFR Part 264.140(c), federal facilities are exempt from the requirements of this section.

\section{I-7 FINANCIAL ASSURANCE MECHANISM FOR POST-CLOSURE}

Under 40 CFR Part 264.140(c), federal facilities are exempt from the requirements of this section.

\section{I-8 LIABILITY REQUIREMENTS}

Under 40 CFR Part 264.140(c), federal facilities are exempt from the requirements of this section.

\section{I-9 STATE FINANCIAL MECHANISM}

Under 40 CFR Part 264.140(c), federal facilities are exempt from the requirements of this section. 


\section{SECTION J \\ RECORDKEEPING}

This section of the application outlines the recordkeeping and reporting requirements for hazardous waste management units as required by 40 CFR Part 264 and Rule 1200-1-11-.06 of the Rules Governing Hazardous Waste Management in Tennessee.

\section{J-1 MANIFEST REQUIREMENTS}

Not applicable. Buildings 9201-4, 9720-9, 9720-25, 9720-31, 9720-58, OD-8, and CWSA do not receive hazardous wastes from off-site; therefore, this section is not required.

\section{J-2 OPERATING RECORD}

Records and results of waste analyses, as required in 40 CFR Part 264.73(b)(3) and Tennessee Rules 1200-1-11-.02 and .06(5)(d)2(iii), are recorded and maintained in the operating files and databases in the Waste Management Organization. The management, including storage and/or treatment, of hazardous wastes is tracked at all times.

For nonroutine wastes, the Y-12 Plant uses the "Request for Transfer, Storage or Disposal of Radioactive, Hazardous and Special Wastes" form (UCN-2109 form), which is located in Appendix C-2, for identification of waste materials. For routine wastes, the Y-12 Plant uses a"Blanket Request" process or "Stream Identification (SID) Number" process which assigns a specific waste stream a number to allow tracking of the waste. Upon generation of a routine or nonroutine waste, log sheets, completed forms, and generation records are provided by the generator, including the description and quantity of waste materials. These forms are assigned a unique number to facilitate entry into the waste tracking systems used by the WSSO Department. The completed forms are reviewed by a technician or engineer from WSSO to determine the appropriate storage, treatment, or disposal method which is recorded on the form and entered into the data base as applicable. After transporting the waste to the appropriate on-site storage or treatment unit or off-site disposal facility, the forms are signed by WSSO personnel and are maintained by the WSSO Department. Finally, operating logs are maintained which include the current quantity and type of wastes located at each facility. Y-12 is presently developing a more comprehensive waste tracking system which may require the updating and changing of forms and log sheets currently used, but all regulatory recordkeeping requirements will continue to be met. 
The Y-12 Plant Waste Acceptance Plan, discussed in Section C, defines the information required to safely store wastes in these units in accordance with RCRA regulations.

An incident requiring implementation of the Contingency Plan would be reported per Section G. A detailed, written report would be submitted by the Y-12 Environmental Management Department to the TDEC within 15 days of the incident, and a file copy would be maintained by the Environmental Management Department. The report would include:

1. name, address, and telephone number of the owner or operator;

2. name, address, and telephone number of a contact at the unit;

3. date, time, and type of incident (e.g., fire, explosion);

4. name and quantity of material(s) involved;

5. extent of injuries, if any;

6. assessment of actual or potential hazards to public health or environment, if applicable; and

7. estimated quantity and disposition of recovered material that resulted from the incident.

Records of inspections for the units in this permit application are maintained by the WSSO Department. Inspection logs are completed per Section F, Procedures to Prevent Hazards. Copies of example inspection log sheets are provided in Appendix F-2. Groundwater monitoring data is not required for these facilities (Section E).

The DOE is the owner of the Y-12 Plant. The units addressed in this application only receive wastes from the Y-12 Plant. Therefore, it is not required that off-site generators be notified of the status of the Y-12 Plant RCRA permits.

The closure and postclosure cost estimates are not required for federal facilities as indicated in Section I, Closure Plans.

The units addressed in this application are not surface impoundments, waste piles, land treatment units, or landfills. Therefore, no Land Disposal Restricted Certification Program is required. In addition, the requirements of groundwater data recordkeeping are not required. 
The training records for personnel in the Waste Management Organization are maintained by the organization training department. The training coordinator assigned to a designated operating or engineering department maintains these records for that specific department. Training information is discussed in Section $\mathrm{H}$.

Preparation of the annual and biannual reports on the hazardous waste activities at the Y-12 Plant is coordinated and maintained by the Environmental Management Department with data supplied by the WSSO Department and waste generating divisions. These reports address the amount of waste generated, the amount of waste shipped off-site, the amount received, and the amount of waste currently on site.

As part of the annual report on the hazardous waste activities at the Y-12 Plant, wastestream specific waste minimization information is submitted to the TDEC for the Y-12 Plant. This annual report certification is prepared and maintained on file by the Environmental Management Department. Additionally, the biennial Waste Minimization Report is submitted to the EPA which contains similar information. The Y-12 Pollution Prevention Program is designed to reduce the volume and toxicity of hazardous wastes generated at the Y-12 Plant and provides information on the methods of reducing waste to minimize the threat to human health and the environment.

The operating records and reports are prepared, maintained, and available for inspection. Training records on current personnel are kept until closure of the hazardous waste management units. The training records of former employees are maintained for a minimum of 3 years from the date the employee last worked at the Y-12 Plant. Personnel training records accompany the employee during any transfer within the company. 


\section{SECTION K \\ OTHER FEDERAL LAWS}

The Y-12 Plant has reviewed and considers to be in compliance with the following Federal Laws:

- $\quad$ Fish and Wildlife Coordination Act of 1934

- National Historic Preservation Act of 1966

- Wild and Scenic Rivers Act of 1968

- Coastal Zone Management Act of 1972

- Endangered Species Act of 1973

- Occupational Safety and Health Act of 1970

- National Environmental Policy Act, January 1, 1970

- Federal Water Pollution Control Act of 1977

- Clean Water Act

- National Emission Standards for Hazardous Air Pollutants, and

- Toxic Substances Control Act

- Clean Air Act

Information will be provided by $\mathrm{Y}-12$ at the request of the TDEC office. 


\section{SECTION L \\ ORGANIC AIR EMISSIONS}

Organic air emissions monitoring is not required for Buildings 9201-4, 9720-9, 9720-25, 9720-31, 9720-58, 9811-1, and CWSA as per the requirements of 40 CFR Part 264, Subparts $\mathrm{AA}$ and $\mathrm{BB}$. 


\section{SECTION M \\ SOLID WASTE MANAGEMENT UNITS}

Based on information from the State, material on solid waste management units at the Oak Ridge Y-12 Plant is not required for individual Part B permit applications because the entire ORR is covered by the ORNL Hazardous and Solid Waste Amendments Permit (HSWA TN001) for Building 7652 (a hazardous waste storage facility). The HSWA Permit was issued on September 26, 1986. 


\section{SECTION N \\ CERTIFICATION}

I certify under penalty of law that this document and all attachments were prepared under my direction and supervision in accordance with a system designed to ensure that qualified personnel properly gather and evaluate the information submitted. Based on my inquiry of the person or persons who manage the system and of those persons directly responsible for gathering the information, the information submitted is to the best of my knowledge and belief, true, accurate, and complete. I am aware that there are significant penalties for submitting false information, including the possibility of fine and imprisonment for knowing violations.

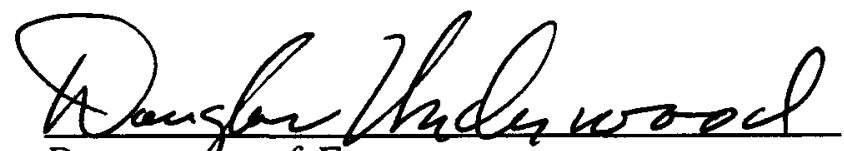

Department of Energy

Owner and Operator

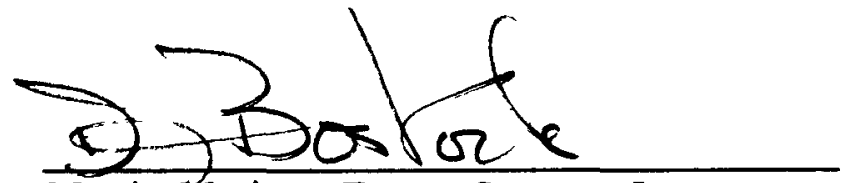

Martin Marietta Energy Systems, Inc.

Co-Operator
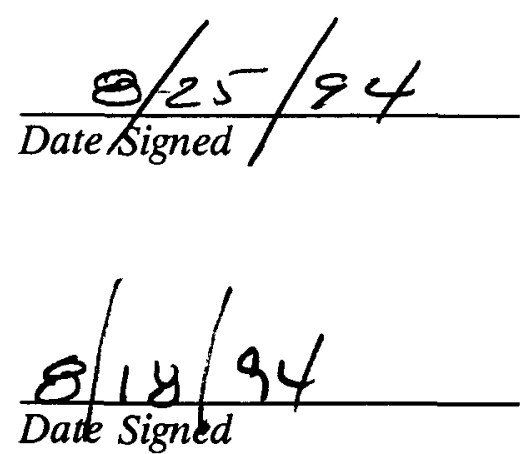

The Department of Energy and its operating contractor, Martin Marietta Energy Systems, Inc., have jointly signed this application as the operator of the permitted facility. The Department has determined that dual signatures best reflect the actual apportionment of responsibility under which the Department's RCRA responsibilities are for policy, programmatic, funding and scheduling decisions, as well as general oversight, and the contractor's $R C R A$ responsibilities are for day-to-day operations, including but not limited to, recordkeeping, reporting, and contingency planning. For purposes of the certification required by 40 CFR Section 270.11(d) and Tennessee Rule 1200-1-11-.07(2)(a)10, the Department's and Martin Marietta Energy Systems, Inc.'s, representatives certify, to the best of their knowledge and belief, the truth, accuracy and completeness of the application for their respective areas of responsibility. 


\section{TENNESSEE DEPARTMENT OF CONSERVATION \\ Cuscoms House \\ 701 Broadway \\ Nashrille, IN 37243}

October 24, 1991

Mr. Rober̃oj. Spence

Y-12 Site Manager

Department of Energy

P.O. Box 2001

Oak Ridge, TN 37831-8555

RE: Reoource Conservation and Recovery Act Part B Permit Maps

Dear Mr. Spence:

The DIfision of Solid Wasce Mangement is in recelpe of your October 9, 1991, letrer requesting a varlance from the mapping scales required in Rule 1200-111-.07(5)(-8)1.7-of the Tennessed Basardous Ware Mnngement Regularions. -

Due to the nature of the Department of Energy Reservation at Oak Rldge, tbe D171810n of Sol1d haste Management does not foresee ang problem witb granc1ng this request. You may use tbe scales that have been requested 10 your letter.

Please feel free to contace either BIII Krispin or Jackie Okoreeh-Bash $1 f$ you have any queselons regarding this letter.

Sincerely,

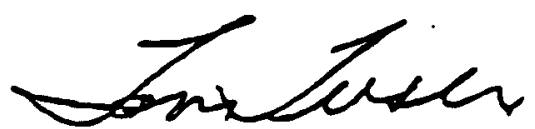

Tom Ilesler, Direcror

Division of Sol1d Weste Managemeat

JII/BK/F101 1297

CC: Sherry Lankford, DOE

H11112m Brown, MESS/Y-12

Gary Bodenstein, DOE

H. G. MeVill lan, DOE

James Scarbrough, EPA

B111 RIIspin; IDEC/SHM

Jack1e Okoreeb-Beah, IDEC/SKM

Eard Leming, IDEC 
APPENDIX B-1

MAPS 


\section{Map 6}

\section{The Y-12 Plant Storm Sewer System Master Plan Map}

The Y-12 Plant Storm Sewer System Master Plan Map has been determined by the U.S. Department of Energy to contain UNCLASSIFIED CONTROLLED NUCLEAR INFORMATION (UCNI) and is not to be disseminated to the public. The document must be protected as required in 10 CFR Part 1017 and its implementing orders. Unauthorized dissemination of the material is subject to civil and criminal sanctions under section 148 of the Atomic Energy Act of 1954, as amended (42 U.S.C. 2168).

The Y-12 Plant Storm Sewer System Master Plan Map was submitted as a part of the first revision of this document. If additional copies of this map are needed, please contact C. M. LaBorde at (615) 576-5603. 
APPENDIX B-2

WIND ROSES 


\section{WIND ROSE for Tower E( 10m) for 01/01/90 - 12/31/90}

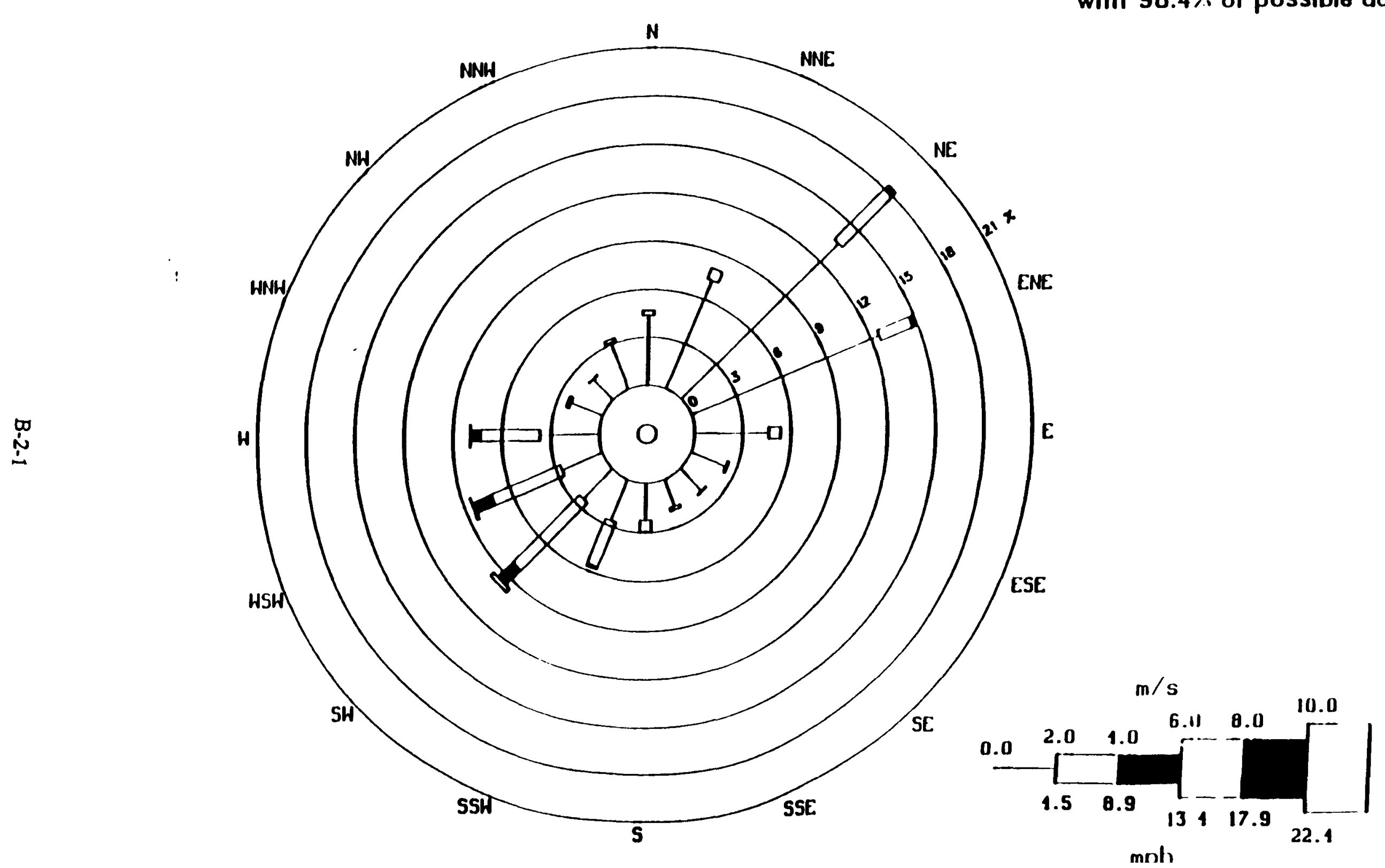


WIND ROSE for Tower $E(30 \mathrm{~m})$ for $01 / 01 / 90-12 / 31 / 90$

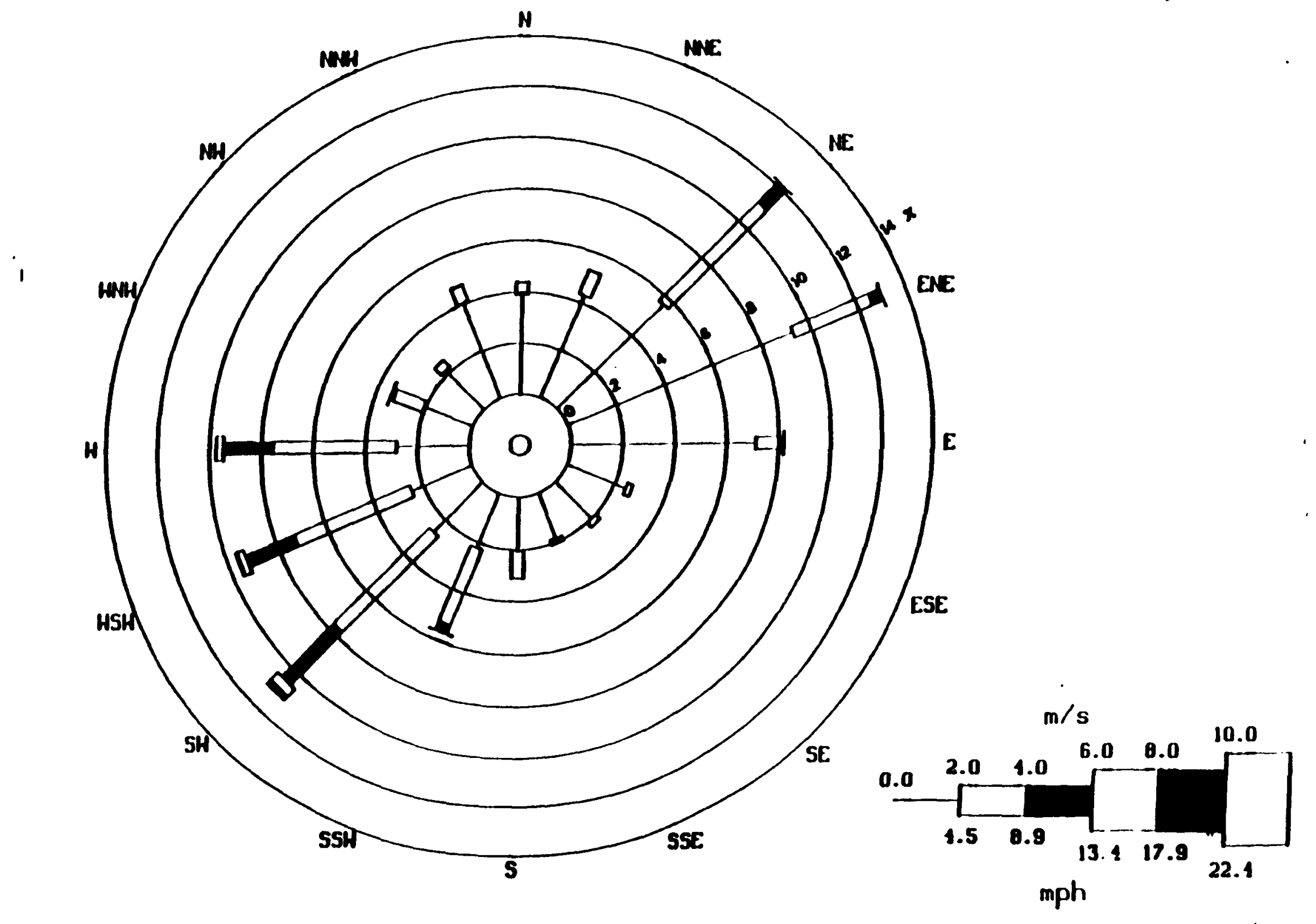




\section{WIND ROSE for Tower W( $10 \mathrm{~m})$ for 01/01/90 - 12/31/90}

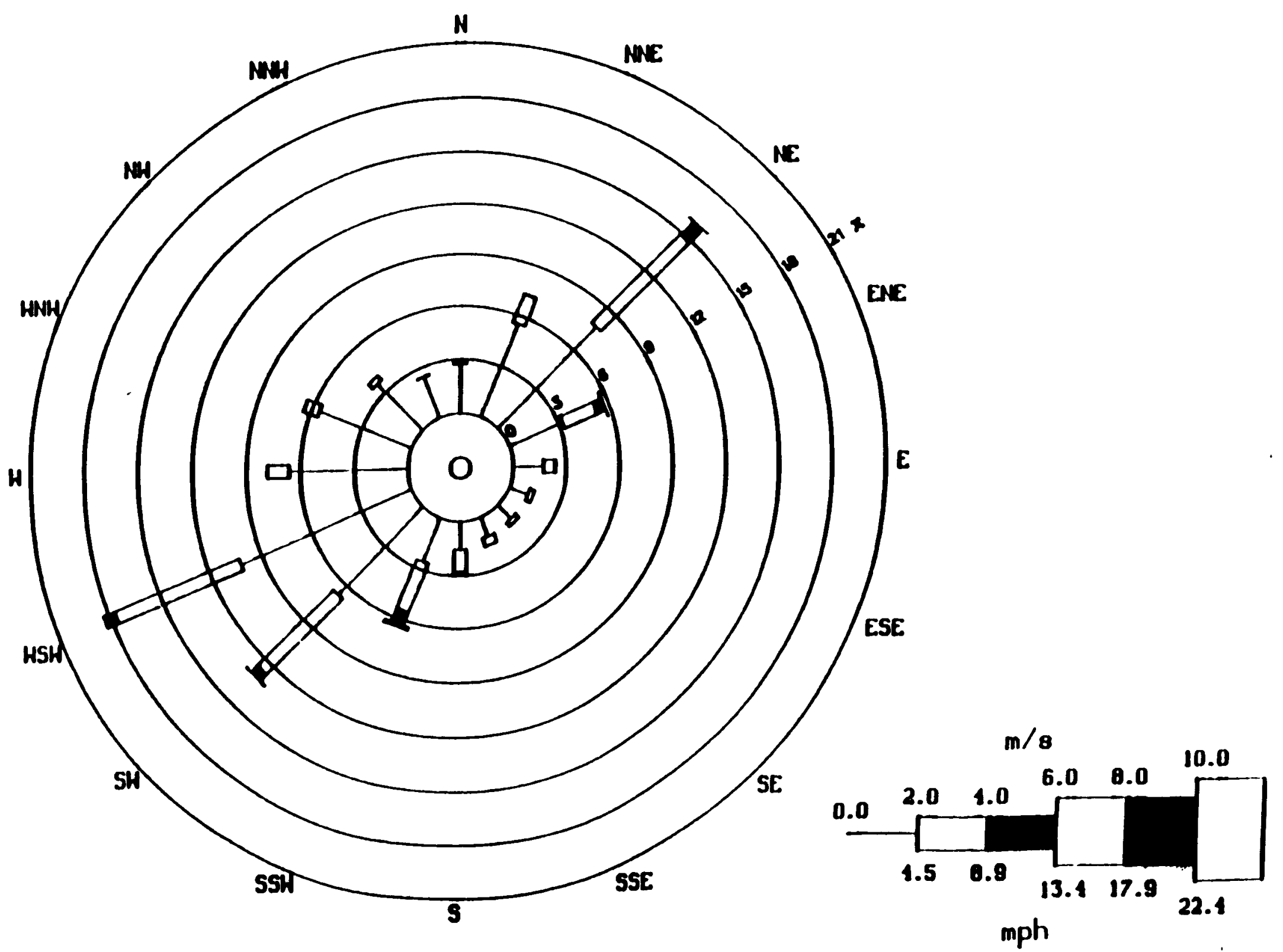


APPENDIX C-1

TYPICAL WASTE ANALYSIS DATA 


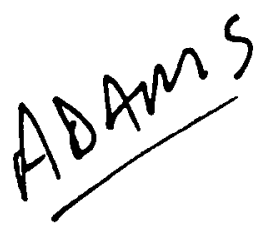

UNCIASSIFIED

OFFICIAL REPORT

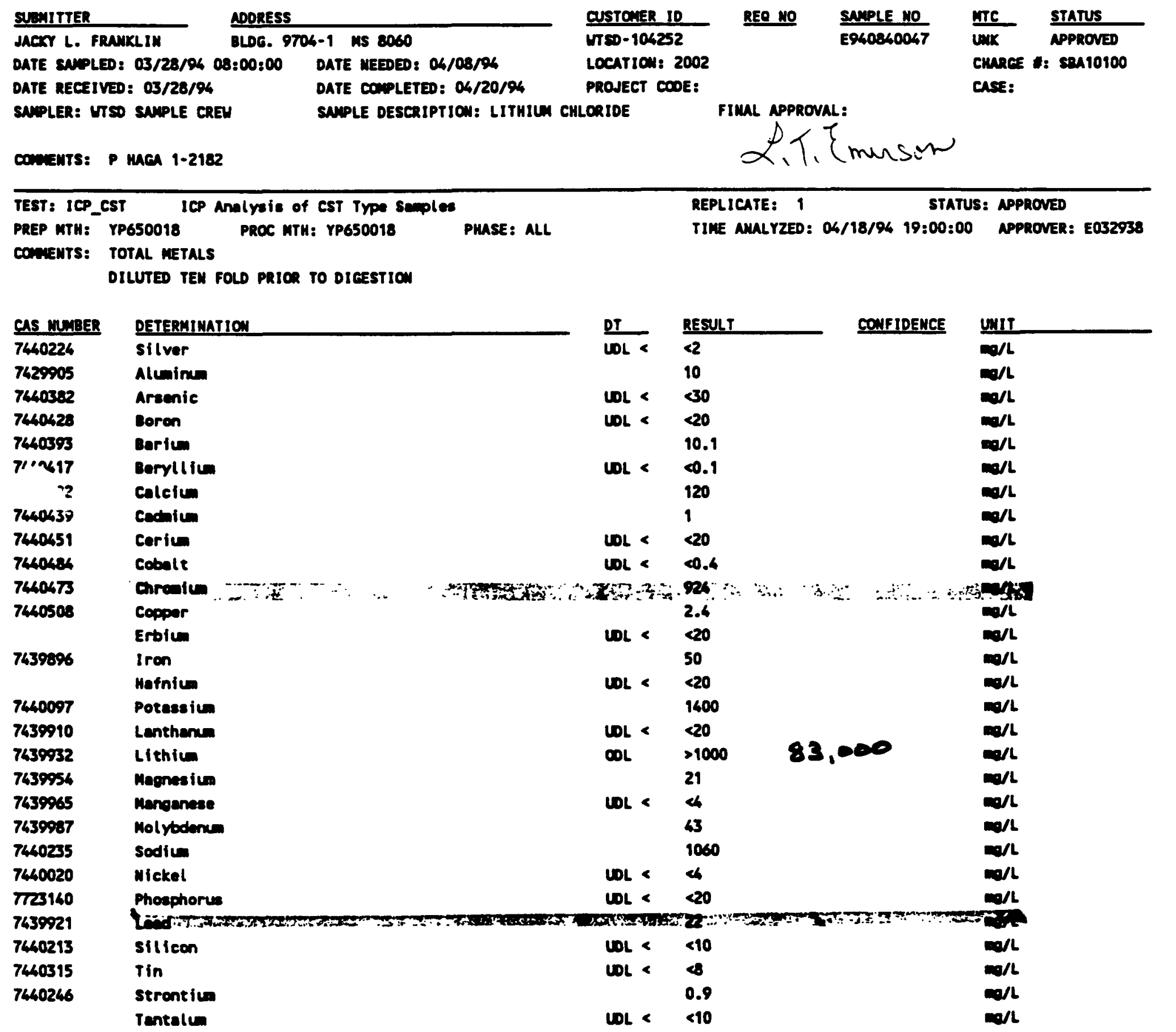

UNCIASSIFIED 
UNCIASSIFIED

OFFICIAL REPORT

SANLE E940840047

$\begin{array}{ll}7440291 & \text { Thorium } \\ 7440326 & \text { Titanium } \\ 7440622 & \text { Vanedium } \\ & \text { Tunesten } \\ 7440666 & \text { Zinc } \\ 7440677 & \text { Zirconium }\end{array}$

Y-12 ALALTICAL SERVICES ORCANIzATION

$\begin{array}{ll}W L< & <20 \\ W L< & <0.6 \\ W L< & <1 \\ W L< & <10 \\ W L & >1000 \quad 5,600 \\ W L< & <0.4\end{array}$

PACE 2 OF 2

$m / L$

$m / 2$

$m / l$

$m / 2$

$w / L$

$m / 1$
TEST: IC_PREP

PREP MTH:

CAS MUMBER DETERMIMATION

TEST: IC_TSCA

PREP MTH:

ION CHROMATOERAPHY FOR TSCA

pace ити:

PHASE:

PUASE:
REPLICATE: 1 STATUS: APPROVED

TIME AMALYZED: 04/08/94 07:21:19 APPROVER:

CAS MUMBER DETERMIMATION

Fluoride

chloride

sulfur as sulfote

DT RESULT __ CONFIDENCE UNIT

REPLICATE: 1 STATUS: APPROVED

TIME AKALYZED: 04/15/94 00:00:00 APPROVER: E005697

DT

REXULT

$<500$

CONFIDENCE

360000

LiIT

$\omega / 8$

$<500$

$\mathrm{cos} / \mathrm{s}$

uovo

IC_mast
MTH:
Ion Chromtesraphy (Waste ENMLLS) Bldo 9995

PROC MTH:

THIS TEST UAS CANCELLED
REPLICATE: 1

TIME AMLYZEO:
STATUS: CAYCELLED

APprover: 


\section{UNCLASSIFIED}

PRELIMIMARY REPORT

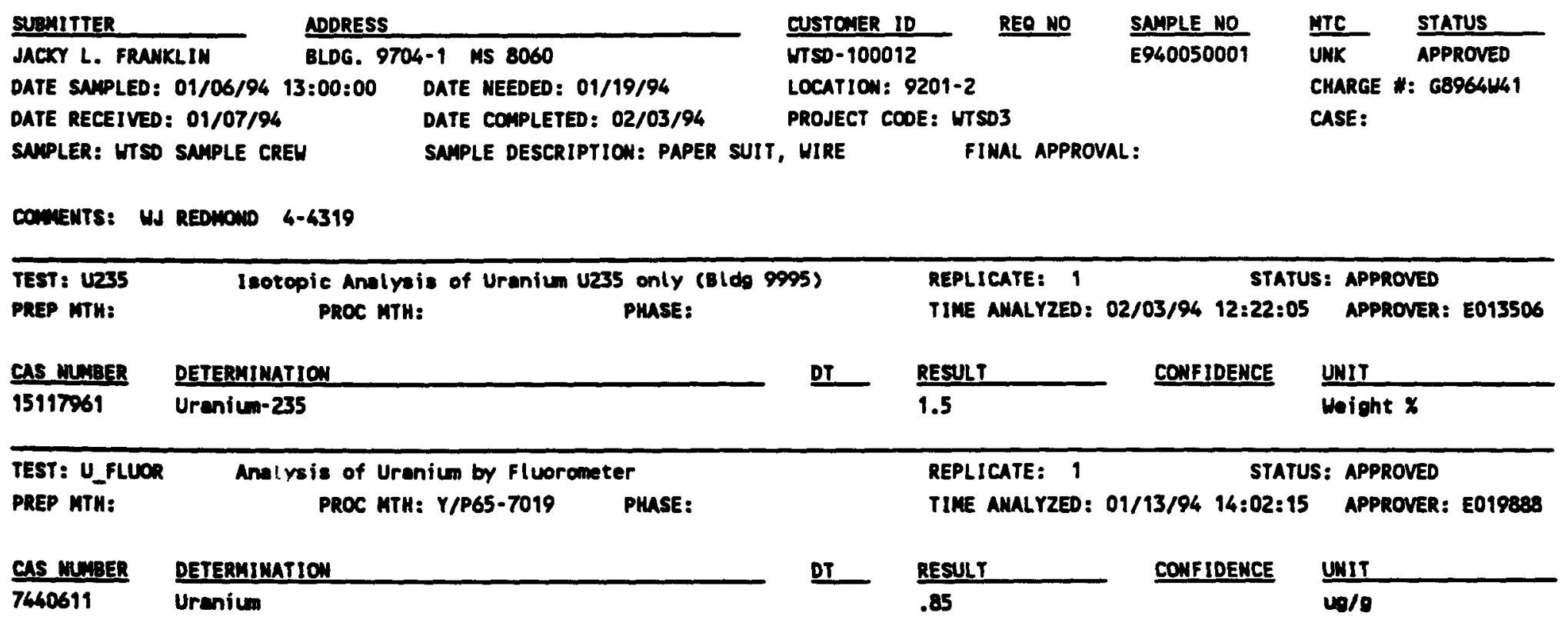




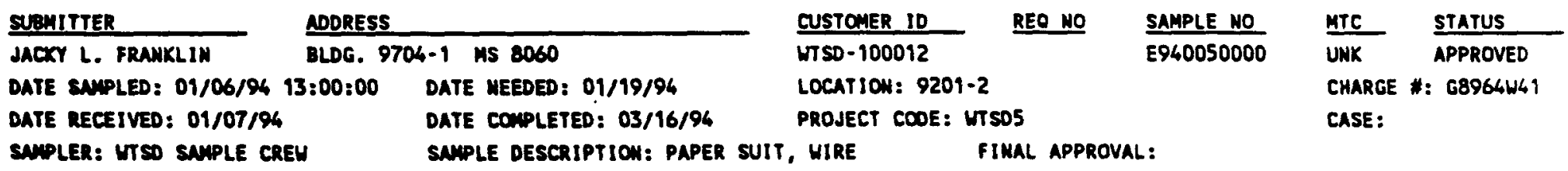

coments: Ud REDions $4-4319$

\begin{tabular}{|c|c|c|c|c|c|c|}
\hline $\begin{array}{l}\text { TEST: ALEETS } \\
\text { PREP MTH: }\end{array}$ & $\begin{array}{l}\text { ALPMA DETA ACTIVITY FCR MASTE } \\
\text { PROC MTH: }\end{array}$ & PHASE: & & $\begin{array}{l}\text { REPLICATE: } 1 \\
\text { TIME AWALYZED: }\end{array}$ & $\begin{array}{r}\text { Status } \\
01 / 13 / 94 \text { 00:00:00 }\end{array}$ & $\begin{array}{l}\text { APPROVED } \\
\text { APPROVER: E019888 }\end{array}$ \\
\hline CAS Munes & DETERnINATIOO & & DT & RESULT & COWFIDENCE & UNIT \\
\hline 12587461 & Alphe ectivity & & & 9 & $+1-6.6$ & $p c / g$ \\
\hline 12587472 & $\begin{array}{l}\text { tete ectivity } \\
\text { Total Activity }\end{array}$ & & & $\begin{array}{l}4.8 \\
14\end{array}$ & $\begin{array}{l}+1-6 \\
+1 \cdot 8.9\end{array}$ & $\begin{array}{l}\mathrm{PC} / \mathrm{g} \\
\mathrm{PC} / \mathrm{g}\end{array}$ \\
\hline
\end{tabular}

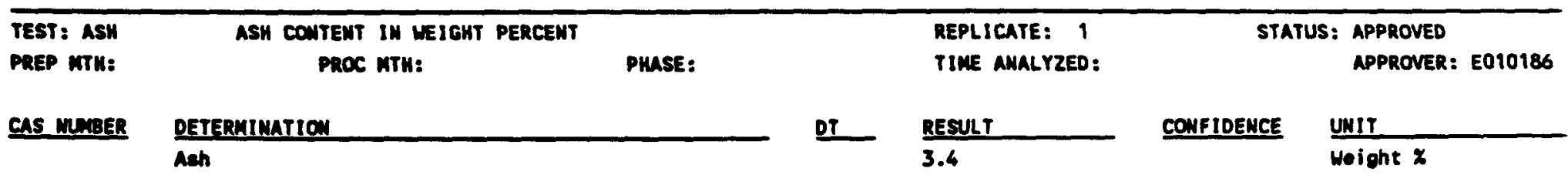

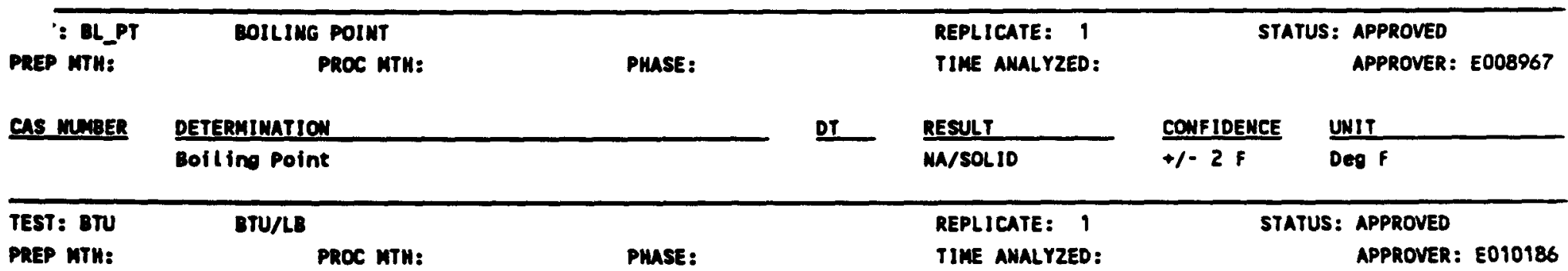

CAS MUMER $\frac{\text { DETERMIMATION }}{\text { STU }}$ DT $\frac{\text { RESULT }}{8300}$ CONFIDEMCE

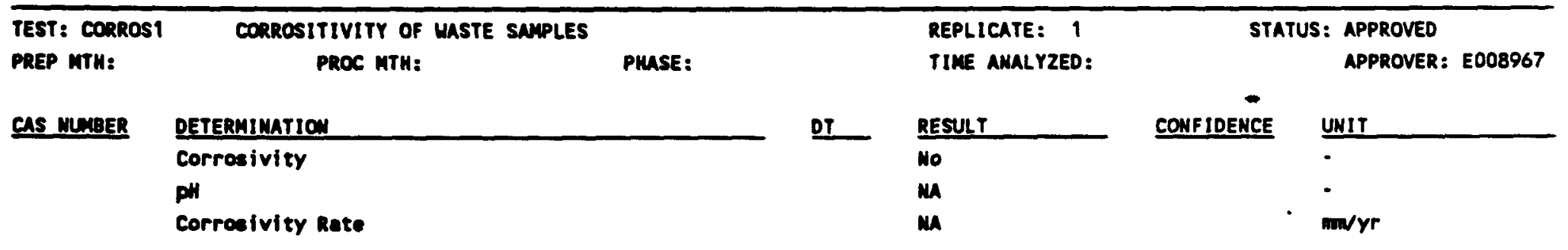

\begin{tabular}{lccc}
\hline TEST: CS137 & CesiL 137 & REPLICATE: 1 STATUS: APPROVEO \\
PREP MTH: & PROC MTH: & PHASE: & TIME AMALYZED: 01/31/94 00:00:00 APPROVER: E019888
\end{tabular}

UNCLASSIFIED 


\section{UNCLASSIFIED}

OFFICIAL REPORT

SUPLE E940050000

\begin{tabular}{|c|c|c|c|c|}
\hline CAS MMBER & DETERMIMATIOY & RESULT & COMF IOENCE & UNIT \\
\hline 10045973 & Cesin-137 & 0.14 & $+1-0.75$ & $\mathrm{pC} / \mathrm{g}$ \\
\hline & Minimn Detecteble Activity Co137 & 1.1 & & PC/g \\
\hline
\end{tabular}

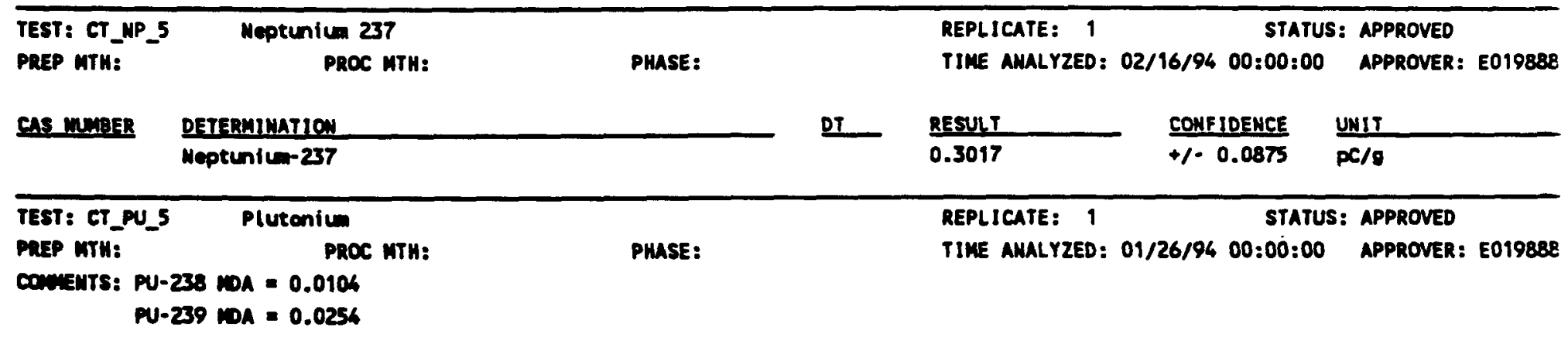

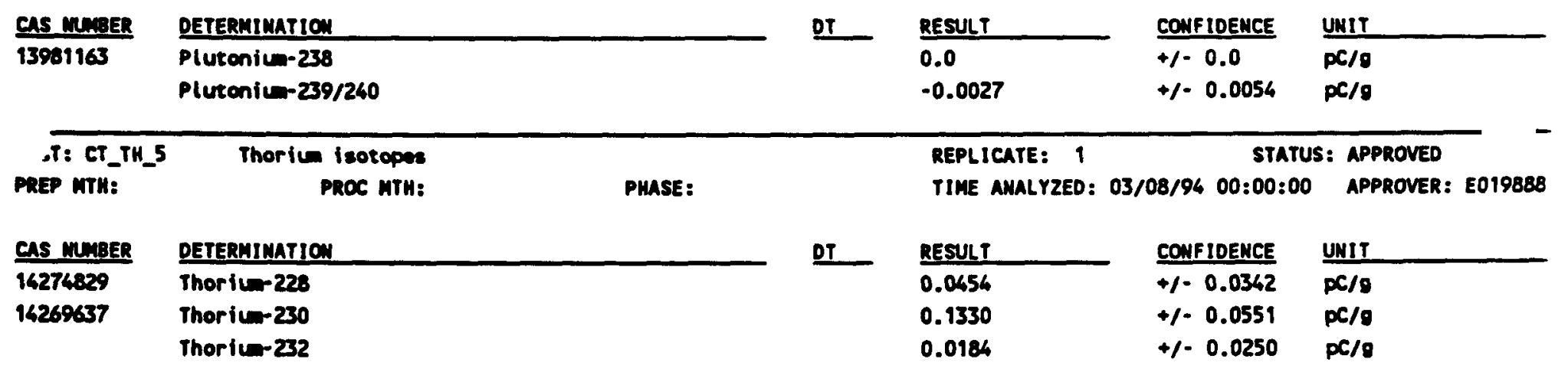

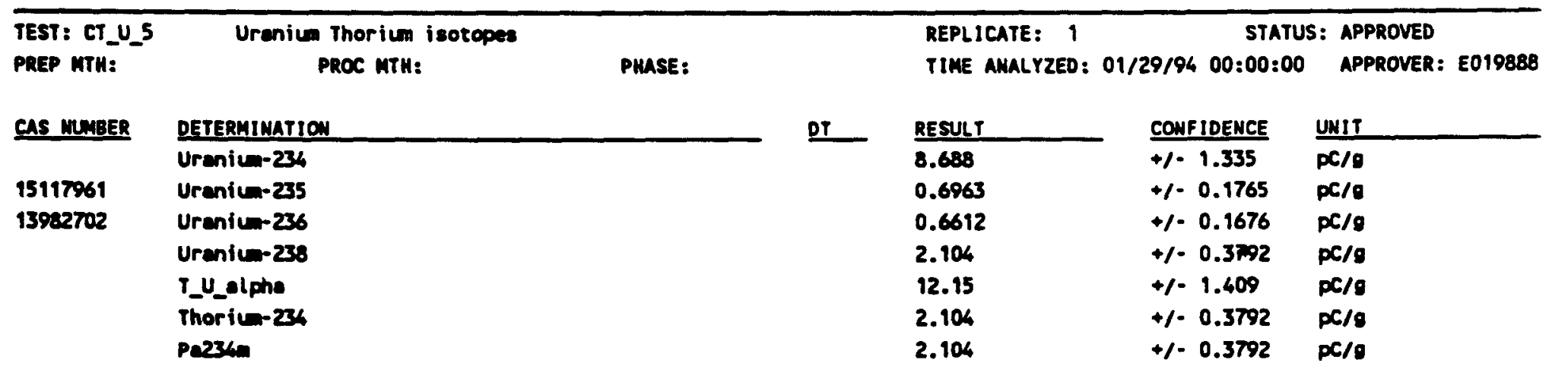

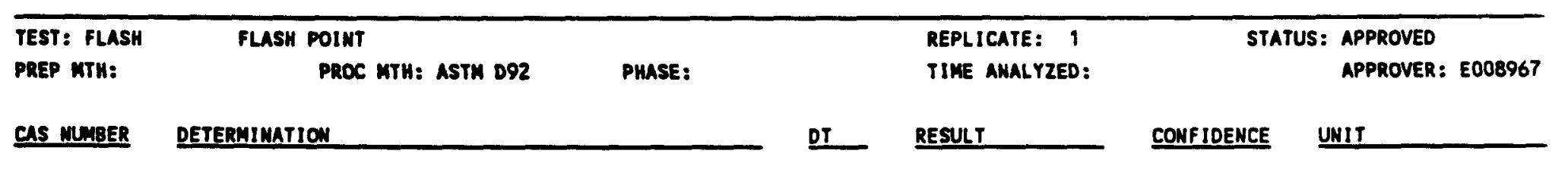




\section{UNCLASSIFIED}

OFfICIAL REPORT

SAPLE E940050000

Flach Point

MA/SOLID

$+1-9 F$

Deg $F$

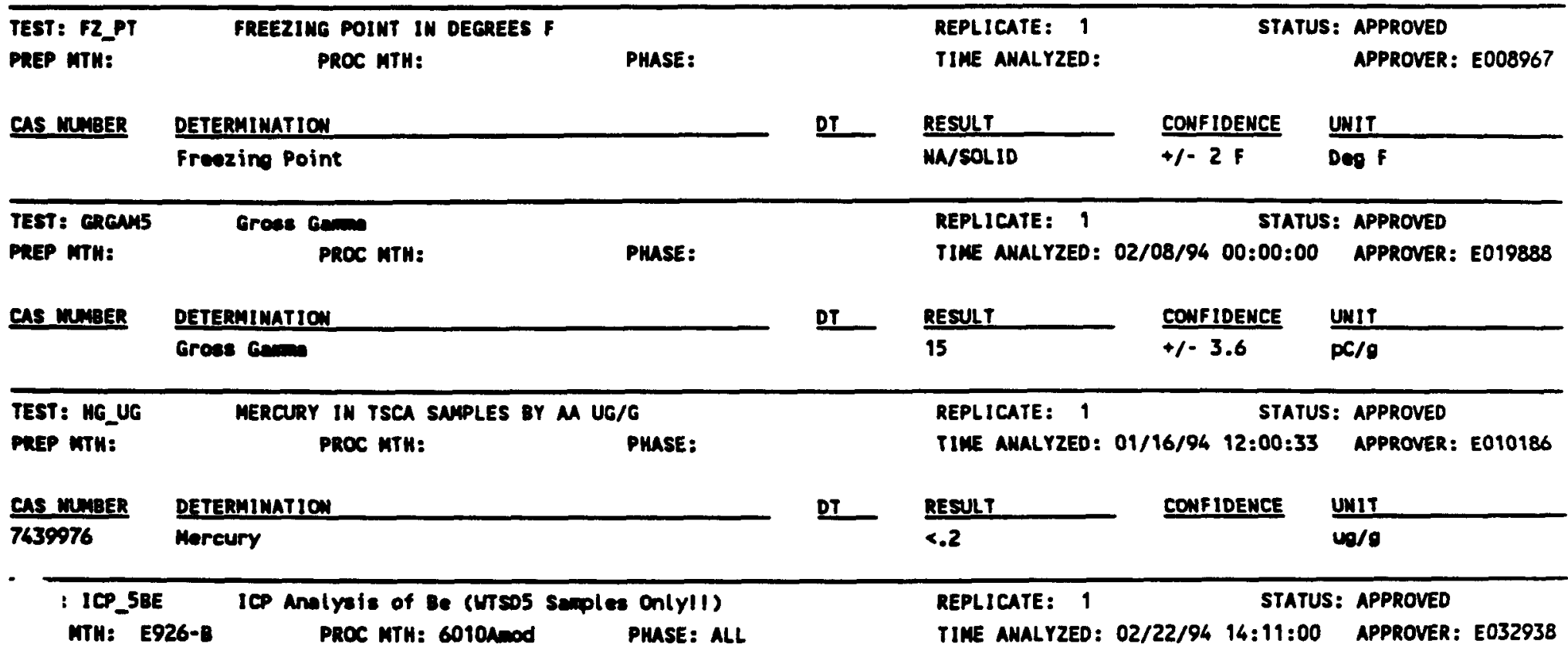

ComiENS: Results obtained from -1em subsemple and mor not be representative of

suple in the container from which the subsemple was taken.

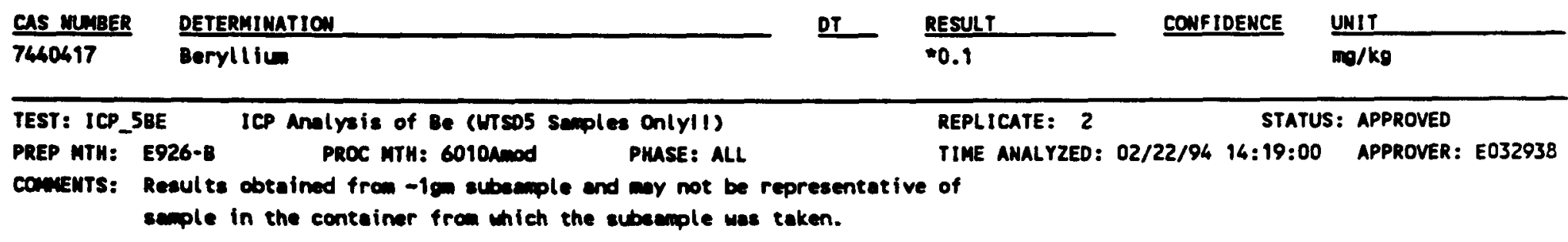

\begin{tabular}{|c|c|c|c|c|c|}
\hline CAS MUMER & DETERMIMATIOU & DI & RESULT & CONF IOENCE & UKIT \\
\hline 7440417 & Beryltiu & $\omega$ & $<0.1$ & & $m g / k g$ \\
\hline
\end{tabular}

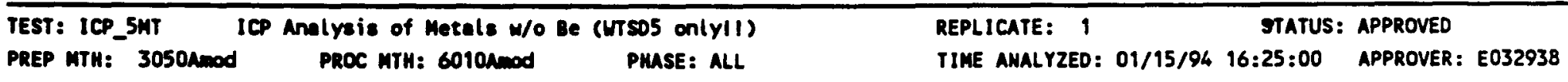

ComeNTS: Results obtained from $-1 \mathrm{~cm}$ subsample and any not be representative of sample

in the conteiner from wich the subsemple was taken.

$\mathrm{II}$ and $\mathrm{P}$ reported even though they are not included in EPA Method 3050A of SH-846. Sb results reported even though Sb is excluded by EPA from Method 30504 of sw-846.

No flags, other then >'s or <'s, have been attached to the results by the

\section{UNCLASSIFIED}




\section{UNCLASSIFIED}

OFFICIAL REPORT

SNWLE E940050000

Y-12 AMALTIICAL SERVICES ORGAMIZATION

PAGE 4 OF 8

ICP grop or the APPROVER.

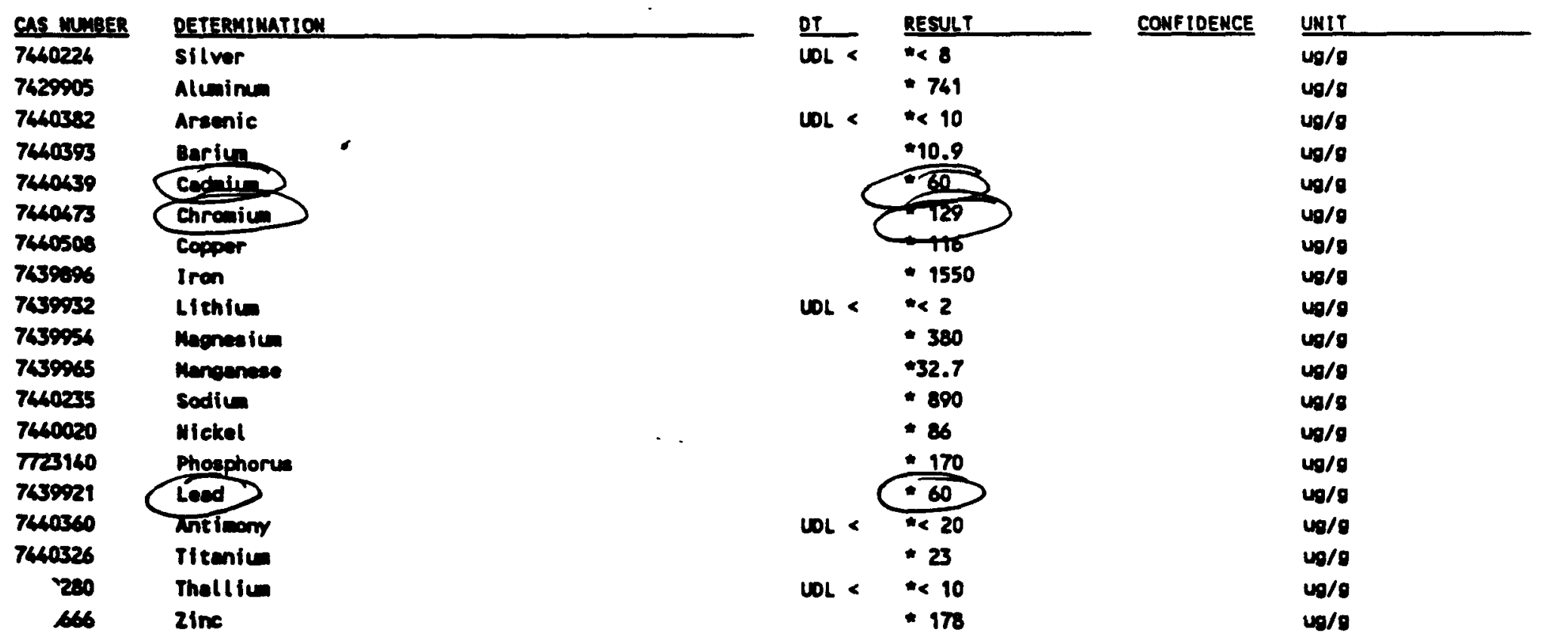

TEST: ICP_SHT ICP Analysis of Metals w/o Be (ITSO5 onlyII)

PREP MTH: 3050naod PROC MTH: 6010anod PMSE: ALL

REPLICATE: 2

STATUS: APPROVED

ConizNTS: Reeulte obtained from $-1 \mathrm{gm}$ subeamole and way not be representotive of semple

in the containar from which the subeseple was taken.

II and P reported even thouph they are not included in EPA Method 3050A of

sU-846. Sb results reported even though Sb is excluded by EPA from Method

30504 of SH-846.

No flags, other than s's or <'s, hove been attached to the results by the

ICP grous or the APPROVER.

\begin{tabular}{|c|c|c|c|c|c|}
\hline CAS MUBER & DETERHIMATION & DT & RESULT & CONFIDENCE & UWIT \\
\hline 7440226 & silvar & WOL & $<8$ & & ug/s \\
\hline 7429905 & Almimn & & 871 & & 40 \\
\hline 7440582 & Arsenic & $\mathbf{W L}$ & $<10$ & - & $40 / 8$ \\
\hline 7440593 & Dariv & & 11.8 & & $\omega / \theta$ \\
\hline 7440439 & Codmien & & 28 & & $40 / 8$ \\
\hline 7460473 & Chromiu & & 109 & & $40 / 9$ \\
\hline 7640503 & Copper & & 158 & & uo/o \\
\hline 7639896 & Iren & & 1670 & & ug/s \\
\hline 7439932 & Lithive & WOL & $<2$ & & $\omega / s$ \\
\hline 7639956 & Magnesiu & & $\$ 10$ & & ug/o \\
\hline
\end{tabular}

UNCLASSIFIED 


\section{UNCLASSIFIED}

OFFICIAL REPCRT

SAPLE E\%40050000

Y-12 AMALYTICAL SERVICES ORGANIzATION

PAGE 5 OF 8

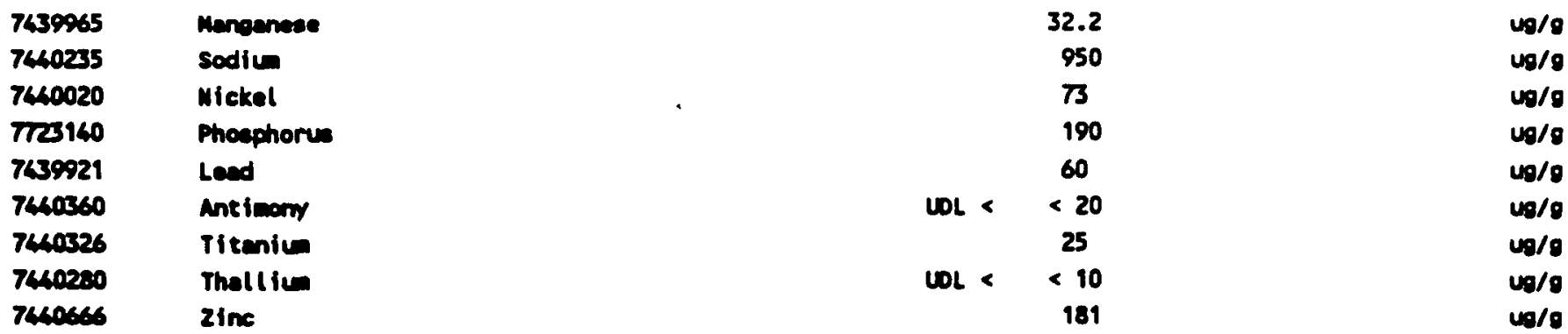

TEST: IC_PREP

PNEP NTU:
PREP FOR IC

PROC MTH:
REPLICATE: 1

TIME AMALYZE:

\section{CAS MUMER DETERMINATION DT DO RESULT UONFIDENCE UNIT}

TEST: IC_TSCA PREP MTH:

ION CHROATOCRAPHY FOR TSCA

proc MTH:
PUASE:
STATUS: APPROVED

:18:23 APPROVER:

\section{CAS MMBER}

DETERMINATION

Fluoride

Chloride

sulfur es sulfate

PUASE:

REPLICATE: 1

STATUS: APPROVED

TIME AMALYZED: 02/14/94 00:00:00 APPROVER: E005697

\section{TEST: KARLF
PREP MTH:}

\section{KARL FISCHER MOISTURE ALALYSIS \\ PROC MTH: Y/OK-8013 \\ THIS TEST MAS CANCELLED}

\section{Dr}

\begin{tabular}{|c|c|}
\hline RESULT T & COMFIDENCE \\
\hline$<500$ & \\
\hline 110000 & \\
\hline 720 & \\
\hline
\end{tabular}

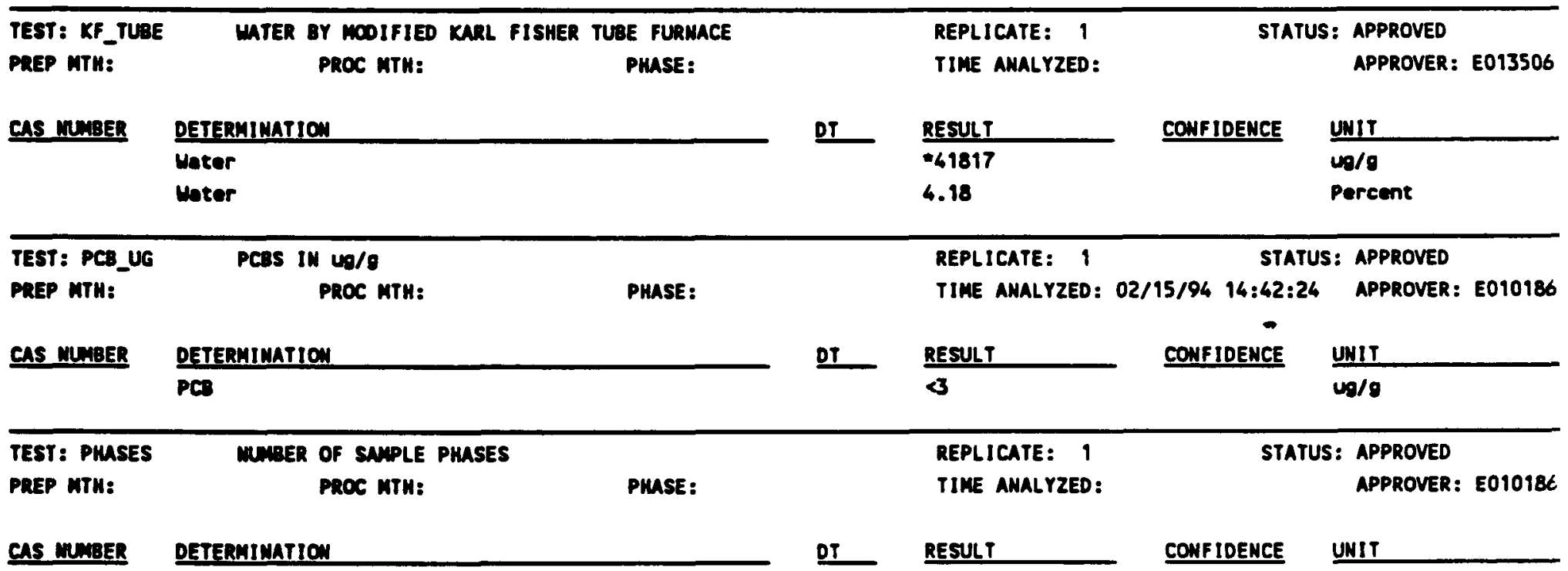

REPLICATE: 1 STATUS: CANCELLED

TIME AKALYZED: 


\section{UNCLASSIFIED}

OFFICIAL REPORT

SUMPE E\$0050000

PHASES

Phese 1 Top

Phase 2

Phace 3

Phase 6

Phase 5
NA/SOLID

$100 x$

MA

MA

MA

MA
Percent

Percent

Percent

Percent

Percent

\begin{tabular}{lcll}
\hline TEST: PH_95 & PH ANOLIYSIS & REPLICATE: 1 \\
PREP WTH: & PROC MTH: & PHASE: & TIME AMALYZED: 01/09/94 10:30:11 APPROVER: EO10186
\end{tabular}

Connents: Holdino Tine was exceeded before the sample was received by the lab

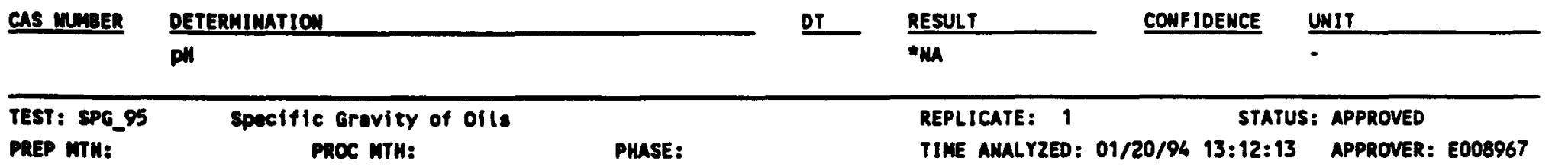

\begin{tabular}{|c|c|c|c|c|c|}
\hline CAS MMBER & DETERMIMATION & or & RESULT & CONFIDENCE & UNIT \\
\hline & Spacific Grovity & & NA/SOLID & $+1=0.0005$ & - \\
\hline
\end{tabular}

\begin{tabular}{|c|c|c|c|c|c|c|}
\hline $\begin{array}{l}\text { : TC99_95 } \\
\text { ити: }\end{array}$ & $\begin{array}{l}\text { TECMNETIUN } 9 \text { OW MASTE SAMPLES } \\
\text { PROC MTH: }\end{array}$ & PHASE: & & $\begin{array}{l}\text { REPLICATE: } 1 \\
\text { TIME AMALYZEO: }\end{array}$ & $\begin{array}{r}\text { STATUS: } \\
02 / 15 / 94 \quad 09: 40: 36\end{array}$ & $\begin{array}{l}\text { : APPROVED } \\
\text { APPROVER: EO }\end{array}$ \\
\hline CAS MUBER & DETERMIMATIOY & & DT & RESULT T & CONFIDEMCE & UNIT \\
\hline & Technetiun-99 & & & .09 & $+/-.03$ & $p C / \theta$ \\
\hline
\end{tabular}

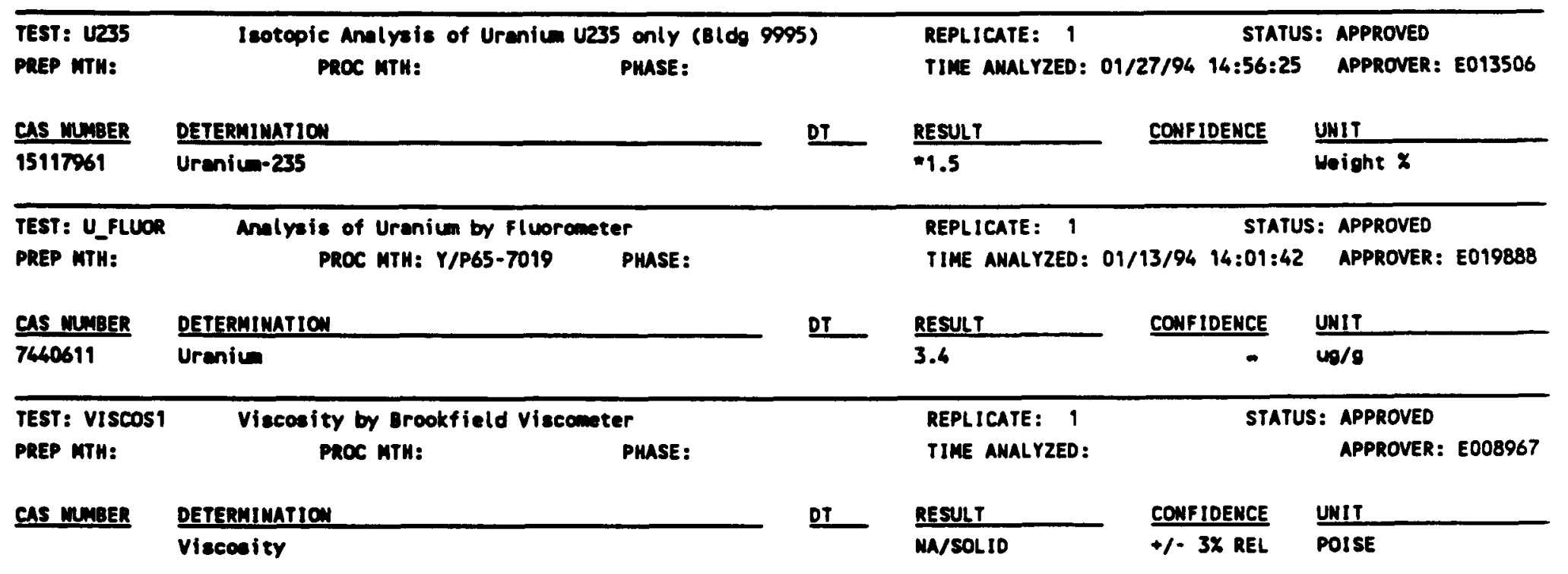




\section{UNCLASSIFIED}

OFFICIAL REPORT

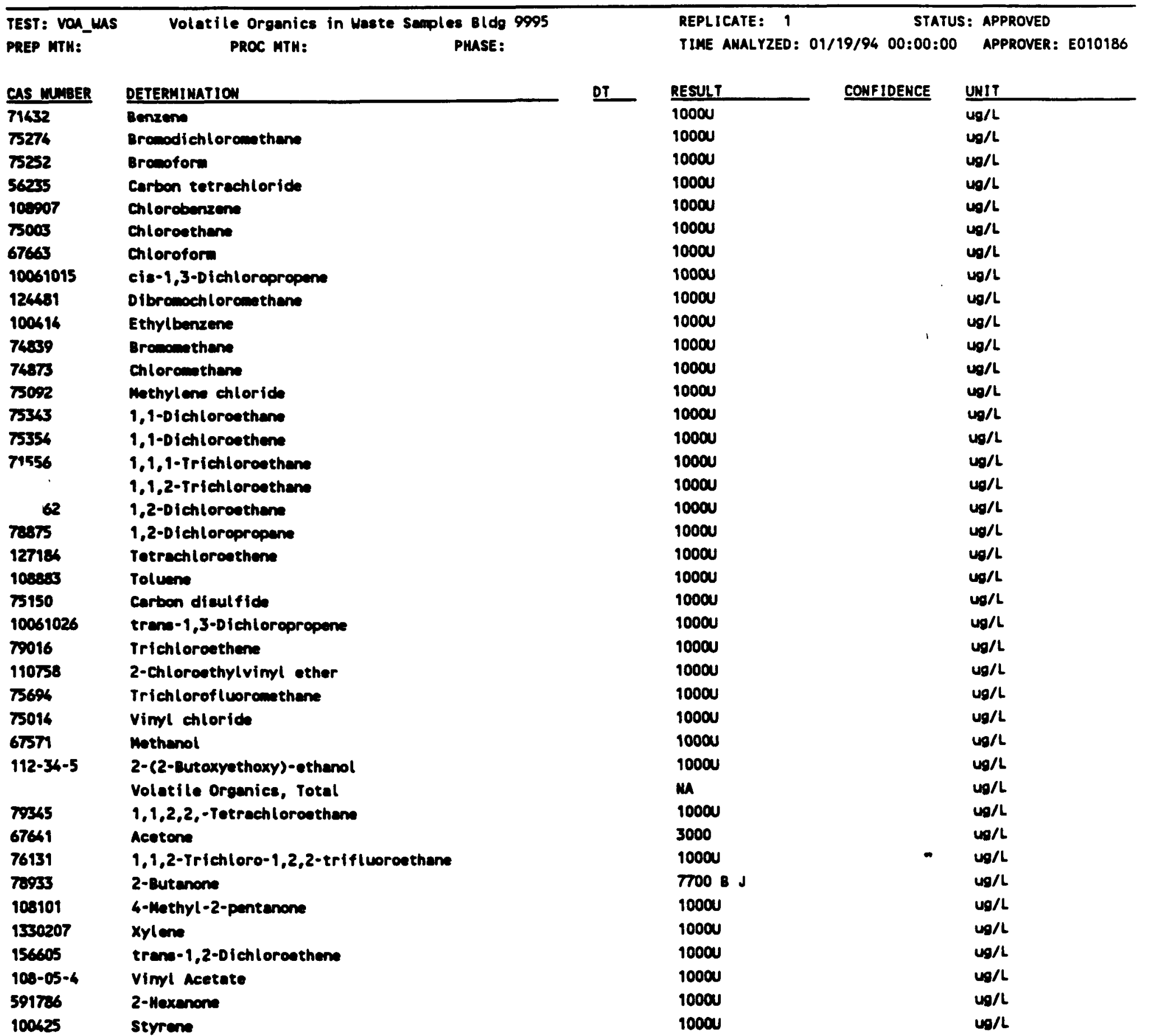

UNCLASSIFIED 


\section{UNCLASSIFIED}

OFFICIAL REPORT

- nuplicate resulte for this determination are included in this report 
UNCLASSIFIED

OFFICIAL REPORT

$02 / 03 / 94 \quad 12: 24: 12$

\section{SUBAITTER}

JACKY L. FRANKLIN DATE SAYPLED: 01/06/94 13:00:00 DATE RECEIVED: 01/07/94 SNMPLER: UTSD SAMPLE CREU ADORESS BLDG. 9704-1 MS 8060

Y-12 AMALYTICAL SERVICES ORGAMIZATION OATE MEEDED: 01/19/94 DATE COMPLETED: 02/03/94 SNIPLE DESCRIPTION: PAPER SUIT, HIRE

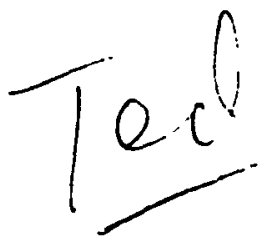

PAGE 1 OF 1

COMENTS: WJ REDMOND $4-4319$

\begin{tabular}{|c|c|c|c|c|c|}
\hline $\begin{array}{l}\text { TEST: UZ3S } \\
\text { PREP HTH: }\end{array}$ & $\begin{array}{l}\text { Isotople Anolyeis } \\
\text { PROC MTH: }\end{array}$ & $\begin{array}{l}5 \text { only (Bldg 9995) } \\
\text { PHASE: }\end{array}$ & $\begin{array}{l}\text { REPLICATE: } 1 \\
\text { TIME ANALYZED: }\end{array}$ & $\begin{array}{c}\text { Status: } \\
02 / 03 / 94 \text { 12:22:05 }\end{array}$ & $\begin{array}{l}\text { APPROVED } \\
\text { APPROVER: E013506 }\end{array}$ \\
\hline CAS MUMBER & DETERMIMATION & or & RESULT & CONF IOENCE & UNIT \\
\hline 15117961 & Uranium-235 & & 1.5 & & Neight $x$ \\
\hline
\end{tabular}

TEST: U_FLUOR PREP MTH:
Anolysis of Uranium by Fluorometer PROC MTH: Y/P65-7019 PHASE:

\begin{tabular}{|c|c|c|c|}
\hline CUSTOMER IO & SAMPLE NO & MTC & STATUS \\
\hline แTSD-100012 & $E 940050001$ & UNK & APPROVED \\
\hline LOCATION: $9201-2$ & & CHARG & : G8964W41 \\
\hline PROJECT COOE: UTSO3 & & CASE: & \\
\hline
\end{tabular}

FINAL APPROVAL:

\section{CAS MUMBER}

7440611
DETERMIMATION

Uranium
REPLICATE: 1

STATUS: APPROVED

TIME ANALYZED: 01/13/94 14:02:15

APPROVER : E019888

or

RESULT

CONFIDENCE
UNIT

$49 / 8$ 


\section{UNCLASSIFIED}

OFFICIAL REPORT

03/01/94 13:35:03

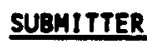

SAMPLE NO E940270011

MTC UNK CHARGE *: SG044332 CASE:

PAGE 1 OF 1

\begin{tabular}{|c|c|c|c|c|c|}
\hline CAS NUMBER & DETERMIMATION & DT & RESULT & CONFIDENCE & UNIT \\
\hline 15117961 & Uranium-235 & & 1.5 & $+1-.2$ & Weight $X$ \\
\hline TEST: U_FLUOR & Analysis of Uranium by Fluorometer & & REPLICATE: 1 & STATUS & : APPROVED \\
\hline PREP MTH: & PROC MTK: Y/P65-7019 PHASE: & & TIME AHALYZED: & 02/24/94 00:00:00 & APPROVER: E019888 \\
\hline CAS NUMBER & DETERHINATION & or & RESULT & CONFIDENCE & $\underline{\text { UNIT }}$ \\
\hline 7440611 & Uraniun & & 0.21 & & $u g / g$ \\
\hline
\end{tabular}


UNCLASSIFIED

OFFICIAL REPORT

$04 / 11 / 94 \quad 14: 19: 12$

Y-12 ANALYTICAL SERVICES ORGANIZATION

2

PAge 1 OF 3

SUBMITTER

JACKY L. FRANKLIN BLDG. $9704-1$ MS 8060

DATE SAMPLED: 02/10/94 17:00:00

DATE RECEIVED: 02/11/94

SAMPLER: WTSD SAMPLE CREW

COMMENTS: $R$ BOYO

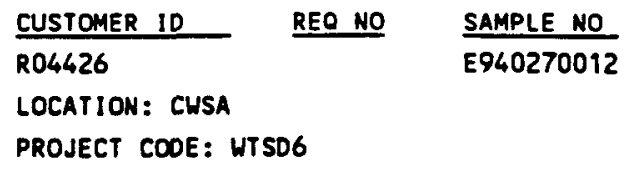

Divinison

\begin{tabular}{lcll}
\hline TEST: BENZENE & Determination of Benzene in Oil (SWB46 8260) & REPLICATE: 1 \\
PREP MTH: & PROC MTH: SW 8468260 & PHASE: & TIME ANALYZED: 03/23/94 00:00:00
\end{tabular}

COMMENTS: Provisional data- holding time exceeded

Results are provisional due to an exceeded holding time

\begin{tabular}{|c|c|c|c|c|c|c|}
\hline CAS NUMBER & DETERMINATION & & DI & RESULT & CONFIDENCE & UNIT \\
\hline 71432 & Benzene & & & $0.5 \mathrm{U}$ & & $\mathrm{mg} / \mathrm{kg}$ \\
\hline TEST: FLASH & FLASH POINT & & & REPLICATE: 1 & status: & S: APPROVED \\
\hline PREP MTH: & PROC MTH: ASTM D92 & PHASE: & & TIME ANALYZED: & & APPROVER: E013506 \\
\hline UMBER & DETERMINATION & & DT & RESULT T & CONF IDENCE & UNIT \\
\hline & Flash Point & & & MA & $+1-9 F$ & Deg F \\
\hline
\end{tabular}

\begin{tabular}{llll}
\hline TEST: ICP_5MT ICP Analysis of Metals w/O Be (WTSD5 only!!) & REPLICATE: 1 \\
PREP MTH: 3050 Amod & PROC MTH: 6010Amod & PHASE: ALL & TIME AHALYZED: 03/30/94 17:44:00
\end{tabular}

COMMENTS: Results obtained from -19m subsample and may not be representative of sample

in the container from which the subsample was taken.

$\mathrm{Ti}$ and $P$ reported even though they are not included in EPA Method 3050A of

SH-846. Sb results reported even though Sb is excluded by EPA from Method

$3050 \mathrm{~A}$ of $\mathrm{SH}-846$.

No flags, other than >'s or <'s, hove been attached to the results by the

ICP group or the APPROVER.

\begin{tabular}{|c|c|c|c|c|c|}
\hline CAS NUMBER & OETERMINATION & or & RESULT & CONFIDENCE & UNIT \\
\hline 7440224 & Silver & $\overline{U D L}<$ & $1<8$ & & $m g / k g$ \\
\hline 7429905 & Aluminum & & -25000 & & $\mathrm{mg} / \mathrm{kg}$ \\
\hline 7640382 & Arsenic & $\omega L<$ & $\approx<10$ & & $\operatorname{mos} / k g$ \\
\hline 7440393 & Barium & & +418 & & $\mathbf{m g} / \mathbf{k g}$ \\
\hline 7640439 & Cadmium & UDL $<$ & $1<4$ & & $\mathbf{m g} / \mathbf{k g}$ \\
\hline 7440473 & Chromium & & - 397 & & $m g / k g$ \\
\hline 7440508 & Copper & & -242 & & $\mathrm{mg} / \mathrm{kg}$ \\
\hline 7439896 & Iron & & 26700 & & $\mathrm{mg} / \mathrm{kg}$ \\
\hline 7439932 & Lithium & & +20 & & $\mathrm{mg} / \mathrm{kg}$ \\
\hline
\end{tabular}

UNCLASSIFIED 


\section{UNCLASSIFIED}

OFFICIAL REPORT

$\begin{array}{ll}7439954 & \text { Magnesium } \\ 7439965 & \text { Manganese } \\ 7440235 & \text { Sodium } \\ 7440020 & \text { Nickel } \\ 7723140 & \text { Phosphorus } \\ 7439921 & \text { Lead } \\ 7440360 & \text { Antimony } \\ 7440326 & \text { Titanium } \\ 7440280 & \text { Thallium } \\ 7440666 & \text { Zinc }\end{array}$

$\begin{array}{rlr} & * 40100 & \mathrm{mg} / \mathrm{kg} \\ & * 406 & \mathrm{mg} / \mathrm{kg} \\ & * 2190 & \mathrm{mg} / \mathrm{kg} \\ & * 36 & \mathrm{mg} / \mathrm{kg} \\ \mathrm{UDL}< & *<20 & \mathrm{mg} / \mathrm{kg} \\ \mathrm{UDL}< & *<20 & \mathrm{mg} / \mathrm{kg} \\ & * 3360 & \mathrm{mg} / \mathrm{kg} \\ \mathrm{UDL}< & *<10 & \mathrm{mg} / \mathrm{kg} \\ & * 115 & \mathrm{mg} / \mathrm{kg} \\ & & \mathrm{mg} / \mathrm{kg}\end{array}$

TEST: ICP_5MT ICP Analysis of Metals w/O Be (WTSDS only!!) REPLICATE: 2 STATUS: APPROVED

PREP MTH: 3050Amod PROC MTK: 6010Amod PHASE: ALL TIME ANALYZED: 03/30/94 17:52:00 APPROVER: E032938

COMAENTS: Results obtained from $-1 \mathrm{gm}$ subsample and may not be representative of sample in the container from which the subsanple was taken.

$T i$ and $P$ reported even though they are not included in EPA Method 3050A of SW-846. Sb results reported even though Sb is excluded by EPA from Method $3050 \mathrm{~A}$ of SH-846.

Ho flags, other than >'s or <'s, have been attached to the results by the ICP group or the APPROVER.

\begin{tabular}{|c|c|c|c|c|c|}
\hline CAS NUMBER & DETERMINATION & DT & RESULT & CONF IDENCE & UNIT \\
\hline 7440224 & silver & NOL $<$ & $<8$ & & $\mathrm{mg} / \mathrm{kg}$ \\
\hline 7429905 & Aluminum & & 25300 & & $\mathrm{mg} / \mathrm{kg}$ \\
\hline 7440382 & Arsenic & $\mathrm{ODL}<$ & $<10$ & & $\mathrm{mg} / \mathrm{kg}$ \\
\hline 7440393 & Barium & & 422 & & $\mathrm{mg} / \mathrm{kg}$ \\
\hline 7440439 & Cadmium & ODL $<$ & $<4$ & & $\mathrm{mg} / \mathrm{kg}$ \\
\hline 7440473 & Chromium & & 403 & & $\mathrm{mg} / \mathrm{kg}$ \\
\hline 7460508 & Copper & & 237 & & $\mathrm{mg} / \mathrm{kg}$ \\
\hline 7439896 & Iron & & 27100 & & $\mathrm{mg}_{\mathrm{g}} / \mathrm{kg}$ \\
\hline 7639932 & Lithium & & 20 & & $\mathrm{mg} / \mathrm{kg}$ \\
\hline 7439954 & Magnesium & & 40600 & & $\mathrm{mg} / \mathrm{kg}$ \\
\hline 7439965 & Manganese & & 431 & & $\mathrm{mg} / \mathrm{kg}$ \\
\hline 7440235 & sodium & & 2150 & & $\mathbf{m g} / \mathrm{kg}$ \\
\hline 7440020 & Nickel & & 98 & & $\mathrm{mg} / \mathrm{kg}$ \\
\hline 7723140 & Phosphorus & & 370 & & $\mathrm{mg} / \mathrm{kg}$ \\
\hline 7439921 & Lead & $\mathbf{\omega O L}<$ & $<20$ & & $\mathrm{mg} / \mathrm{kg}$ \\
\hline 7440360 & Antimony & NOL $<$ & $<20$ & & $\mathrm{mg} / \mathbf{k g}$ \\
\hline 7440326 & Titanium & & 3420 & & $\mathrm{mg} / \mathrm{kg}$ \\
\hline 7640280 & Thallium & $\mathbf{W L}<$ & $<10$ & & $\mathrm{mg} / \mathrm{kg}$ \\
\hline 7440666 & Zinc & & 114 & & $\mathrm{mg} / \mathrm{kg}$ \\
\hline
\end{tabular}

TEST: PCB_UG PREP MTH:
PCBS IN Ug/g

PROC MTH:
REPLICATE: 1

PHASE:
STATUS: APPROVED

TIME ANALYZED: 02/20/94 10:07:12 


\section{UNCLASSIFIED}

OFFICIAL REPORT

SAMPLE E940270012

\begin{tabular}{|c|c|c|c|c|c|}
\hline CAS NUMBER & DETERMINATION & DT & RESULT & CONFIDENCE & UNIT \\
\hline & PCB & & $<60$ & & ug/g \\
\hline TEST: U235 & Isotopic Analys is of Uraniun U235 only (Bldg & 95) & REPLICATE: 1 & STATUS: & : APPROVEO \\
\hline PREP MTH: & PROC MTH: PHASE: & & TIME ANALYZED: & $02 / 22 / 94 \quad 08: 20: 36$ & APPROVER: E013506 \\
\hline CAS NUMBER & DETERMINATION & DT & RESULT & CONFIDENCE & UNIT \\
\hline 15117961 & Uranium-235 & & NA/LOW U & & Weight $x$ \\
\hline TEST: U_FLUOR & Analysis of Uraniun by Fluorometer & & REPLICATE: 1 & STATUS: & APPROVED \\
\hline PREP MTH: & PROC MTH: Y/P65-7019 PHASE: & & TIME ANALYZED: & $02 / 14 / 94 \quad 14: 02: 00$ & APPROVER: E019888 \\
\hline CAS NUMBER & DETERMINATION & DT & RESULT & CONFIDENCE & UNIT \\
\hline 7440611 & Uranium & $\overline{\text { UDL }}$ & $<.14$ & & $u g / g$ \\
\hline
\end{tabular}


APPENDIX C-2

WASTE IDENTIFICATION FORMS 
"ASTE ITEM IDENTIFICATION

\section{ste Item ID Vumber D2. Generator s Name IPrunt।}

13. Badge No.
14. Generator s Phone No. IIS. IIS

I11. Orign Room/Area
16. Charge Number/WO

\begin{tabular}{|c|c|c|c|c|c|}
\hline 17. Origun Div. & 18. Origin Date & 19. Origun Site & I10. Origin Facutiv & |111. Origin Room/Area & 112. Radiologal Area? \\
\hline I13. Est. Tet Vo & 114. Units & IIS. Est. & \begin{tabular}{|l|l|l|l} 
ross Weight & [16. Lnts
\end{tabular} & & \\
\hline
\end{tabular}

CONTAINER INFORMATION (1 of ) If more than one attach Waste Container List (UCN-2109A)

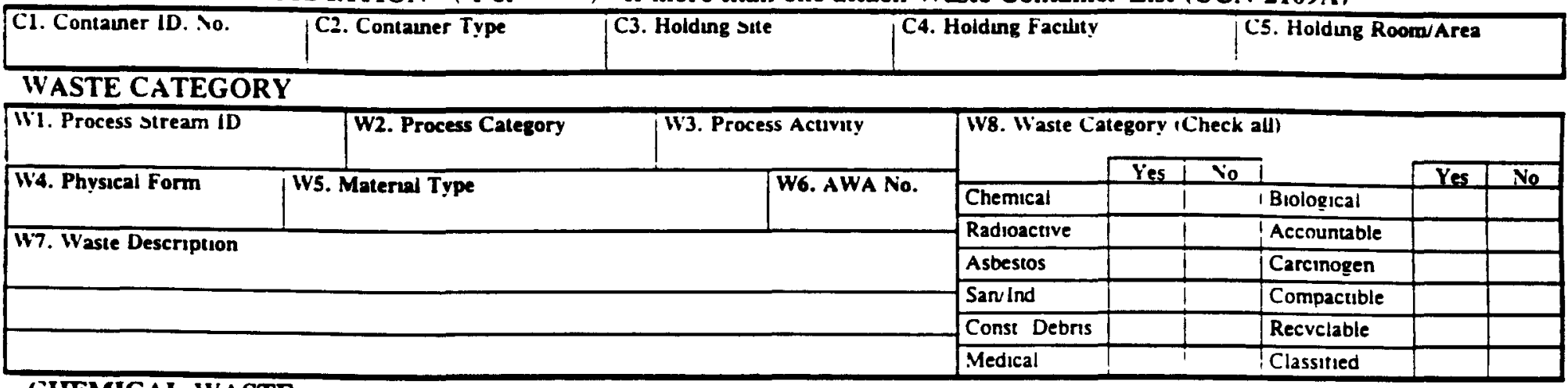

\section{CHEMICAL WASTE}

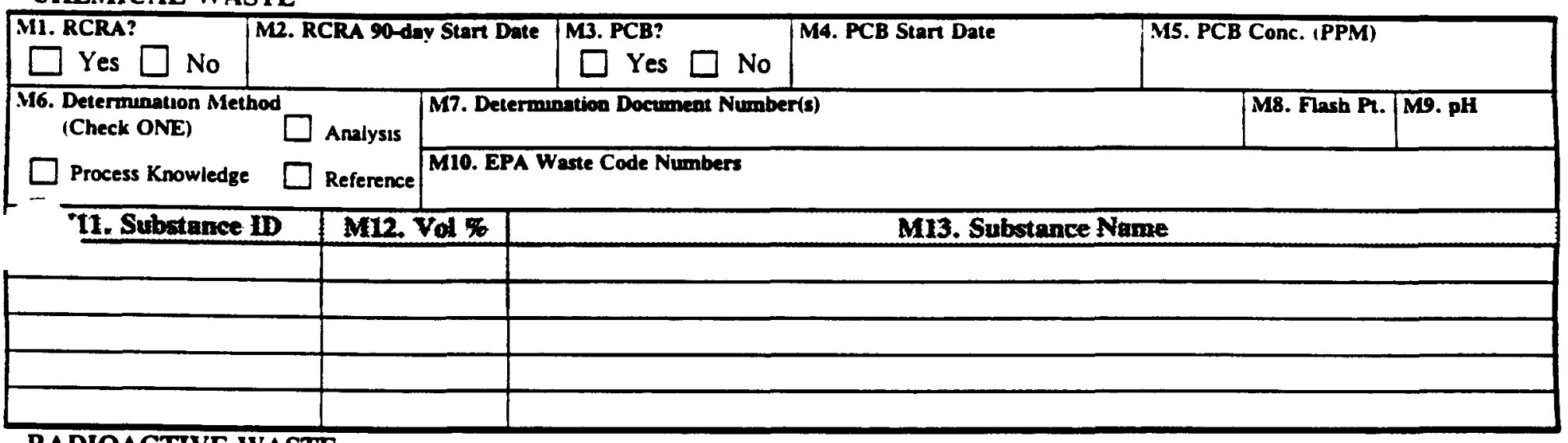

RADIOACTIVE WASTE

R1. RAD Category (Check ONE)

$\square$ TRU $\square$ High-Level

R4. Determunation Method (Check ONE)

$\square$ Analysis

$\square$ Process Knowiedge

$\square$ Reference

R6. Chemucal Form

\begin{tabular}{|l|l|l|l|l|l|l|l|l|}
\hline R7. Isotope & R8. Est. QY & R9. Units & R7. Isotope & R8. Est. Qty & R9. Units & R7. Isotope & R8. Est. Qty R9. Enits \\
\hline & & & & & & & & \\
\hline
\end{tabular}

HANDLING INFORMATION

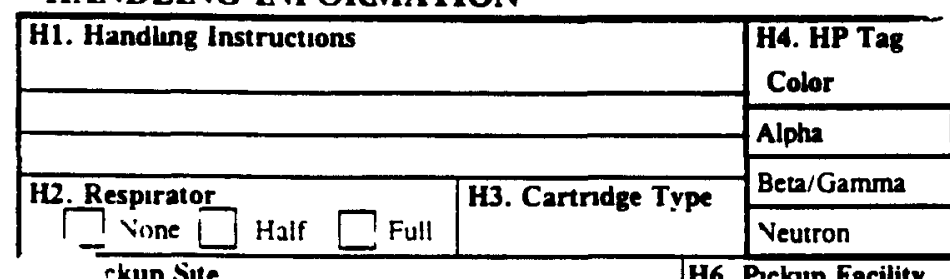

skup Site
H6. Pickup Facility

\section{R2. RAD Handing Type}

R3. UCN 2681 No.

\section{SIGNATURES and APPROVALS}

\begin{tabular}{|c|c|c|c|c|c|}
\hline S1. Generator & Badge & Date & S2. HP Technician & $\begin{array}{l}\text {, Badge } \\
\text { ! }\end{array}$ & Date \\
\hline 53. Verification Ufricer & Badge & Date & S4. Derivauve Classifier & ' Badge & Date \\
\hline
\end{tabular}


(Continuation Page of

\begin{tabular}{|c|c|c|}
\hline $\begin{array}{c}\text { Sequence } \\
\text { Number } \\
1\end{array}$ & \multicolumn{2}{|c|}{ Referenced from WID (UCN-2109)* } \\
\cline { 2 - 3 } & I1. Waste Item ID Number & C1. Contaner ID. No. \\
\hline
\end{tabular}

\section{*ALL WASTE ITEM/CONTAINERS ON THIS FORM} HAVE THE SAME CHARACTERISTICS AS ITEM/CONTANER NUMBER 1

\begin{tabular}{|c|c|c|c|c|c|c|c|c|}
\hline \multirow{4}{*}{$\begin{array}{l}\text { Sequ: } \\
\text { Numoe: }\end{array}$} & 11. Waste Item ID Number & \multicolumn{2}{|c|}{ C1. Contamer ID. No. } & \multicolumn{2}{|c|}{ 18. Origen Date } & \multicolumn{2}{|c|}{ 112. RCRA 90-day Stant Date } & \multirow{3}{*}{$\frac{\text { M14. PCB Start Date }}{\substack{\text { Instrumeat } \\
\text { Identificutran }}}$} \\
\hline & \multirow[t]{2}{*}{ 113. Est. Net Volume } & \multirow[t]{2}{*}{ 114. Units } & \multirow{2}{*}{$\begin{array}{l}\text { H4. HP Tag } \\
\text { Color }\end{array}$} & \multicolumn{2}{|c|}{ Surface Couraminateon } & \multirow{2}{*}{$\begin{array}{l}\text { Dose Rate } \\
\text { at Surface } \\
\text { (Reremfir) }\end{array}$} & \multirow{2}{*}{$\begin{array}{l}\text { Dose Rate } \\
\text { at I Meter } \\
\text { (orem/hel }\end{array}$} & \\
\hline & & & & Transier. & Direci Read. & & & \\
\hline & 115. Est. Gross Weight & I16. Unuts & Alpha & & & & & \\
\hline \multirow[t]{2}{*}{ Comment: } & & & Beta/Gamma & & & & & \\
\hline & & & Neutron & & & & & \\
\hline
\end{tabular}

\begin{tabular}{|c|c|c|c|c|c|c|c|c|}
\hline \multirow{4}{*}{$\begin{array}{l}\text { Sequence } \\
\text { Number }\end{array}$} & \multicolumn{2}{|c|}{ 11. Waste Item ID Number } & C1. Contamer ID. No. & \multicolumn{2}{|c|}{ 18. Orign Date } & \multicolumn{2}{|c|}{ 12. RCRA 90-day start Date } & \multirow{3}{*}{\begin{tabular}{|c|} 
M4. PCB Start Date \\
Intrumant \\
Idemifotions
\end{tabular}} \\
\hline & \multirow[t]{2}{*}{ 113. Est. Net Volume } & \multirow[t]{2}{*}{ I14. Units } & \multirow{2}{*}{$\begin{array}{l}\text { H4. HP Tag } \\
\text { Color }\end{array}$} & $\begin{array}{c}\text { Surince } \\
\text { totom }\end{array}$ & 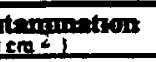 & \multirow{2}{*}{$\begin{array}{l}\text { Dose Rate } \\
\text { of Surface } \\
\text { fanmente }\end{array}$} & \multirow{2}{*}{$\begin{array}{l}\text { Dose Rate } \\
\text { A } 1 \text { Meter } \\
\text { Inutentint }\end{array}$} & \\
\hline & & & & Transter. & Direct Read. & & & \\
\hline & 115. Est. Gross Weight & 116. Units & Alpha & & & & & \\
\hline \multirow[t]{2}{*}{ Comments } & & & Bew/Gamma & & & & & \\
\hline & & & Neutron & & & & & \\
\hline
\end{tabular}

\begin{tabular}{|c|c|c|c|c|c|c|c|c|}
\hline \multirow{4}{*}{$\begin{array}{l}\text { Sequence } \\
\text { Number }\end{array}$} & I1. Waste Item ID Number & Cl. & C1. Contaver ID. No. & \multicolumn{2}{|c|}{ 18. Ongn Date } & \multicolumn{2}{|c|}{ M2. RCRA 90-day Start Date } & \multirow{3}{*}{ M14. PCB Start Date } \\
\hline & \multirow[t]{2}{*}{ I13. Est. Net Volume } & \multirow[t]{2}{*}{ I14. Units } & \multirow{2}{*}{$\begin{array}{l}\text { H4. HP Tag } \\
\text { Color }\end{array}$} & \multicolumn{2}{|c|}{ Surface Contand } & \multirow{2}{*}{ 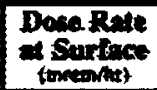 } & \multirow{2}{*}{ 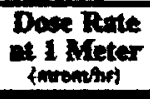 } & \\
\hline & & & & Transfer. & Diroet Read. & & & \\
\hline & I15. Est. Grows Weight & I16. Units & Alpha & & & & & \\
\hline \multirow[t]{2}{*}{ Comments } & & & Beta/Gamma & & & & & \\
\hline & & & Neutron & & & & & \\
\hline
\end{tabular}

\begin{tabular}{|c|c|c|c|c|c|c|c|c|}
\hline \multirow{4}{*}{$\begin{array}{l}\text { Sequence } \\
\text { Number }\end{array}$} & \multicolumn{2}{|c|}{ I1. Waste Item ID Number } & CI. Contaner ID. No. & \multicolumn{2}{|c|}{ 18. Origin Date } & \multicolumn{2}{|c|}{ M2. RCRA 90-day Start Date } & \multirow{3}{*}{ 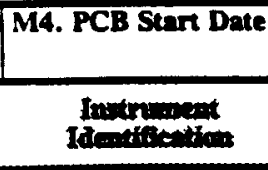 } \\
\hline & \multirow[t]{2}{*}{ I13. Est. Net Volume } & \multirow[t]{2}{*}{ I14. Units } & \multirow{2}{*}{$\begin{array}{l}\text { H4. HP Tas } \\
\text { Color }\end{array}$} & Surtacto & ingeripation & \multirow{2}{*}{$\begin{array}{l}\text { Doee Rate } \\
\text { a Euxtece }\end{array}$} & \multirow{2}{*}{$\begin{array}{c}\text { Dese Rete } \\
\text { at I Metex } \\
\text { fment }\end{array}$} & \\
\hline & & & & Tr:efer: & Dined Read. & & & \\
\hline & I15. Est. Gross Weight & 116. Units & Alphn & & & & & \\
\hline \multirow[t]{2}{*}{ Comments } & & & Bet/Gamma & & & & & \\
\hline & & & Neutron & & & & & \\
\hline
\end{tabular}

\begin{tabular}{|c|c|c|c|c|c|c|c|c|}
\hline \multirow{4}{*}{$\begin{array}{l}\text { Sequence } \\
\text { Number }\end{array}$} & \multicolumn{2}{|c|}{ I1. Waste Item ID Nurnber } & C1. Contaner ID. No. & \multicolumn{2}{|c|}{ 18. Orugan Date } & \multicolumn{2}{|c|}{ M12. RCRA 90-day Stan Date } & \multirow{3}{*}{$\frac{\text { V14. PCB Start Date }}{\substack{\text { Intrinment } \\
\text { Idestification }}}$} \\
\hline & \multirow[t]{2}{*}{ I13. Est. Net Volume } & \multirow[t]{2}{*}{ 114. Units } & \multirow{2}{*}{$\begin{array}{l}\text { H4. HP Tag } \\
\text { Color } \\
\end{array}$} & $\begin{array}{l}\text { Surface } 6 \\
\text { lotent }\end{array}$ & ontention & \multirow{2}{*}{$\begin{array}{l}\text { Dose Rete } \\
\text { at Surface } \\
\text { jowennet }\end{array}$} & \multirow{2}{*}{$\begin{array}{c}\text { Dose Rnte } \\
\text { at } 1 \text { Meter } \\
\text { inuenthr }\end{array}$} & \\
\hline & & & & Trunsfer. & Direct Rand. & & & \\
\hline & 115. Est. Gross Werght & 116. Unuts & Alpha & & & & & \\
\hline \multirow[t]{2}{*}{ Comments } & & & Beta/Gamma & & & & & \\
\hline & & & Neutron & & & & & \\
\hline
\end{tabular}

SIGNATURES and APPROVALS

\begin{tabular}{|l|l|l|}
\hline S1. Generator & Badge & Date \\
\hline S3. Verification Ofricer & Badge & Date \\
\hline
\end{tabular}

\begin{tabular}{|l|l|l|}
\hline S2. HP Technician & Badge & Date \\
\hline S4. Derivative Classifier & Badge & Date \\
\hline
\end{tabular}




\section{Attach Container Packing List and/or Barcode Labels Here (staple)}

\section{WASTE MANAGEMENT SECTTON}

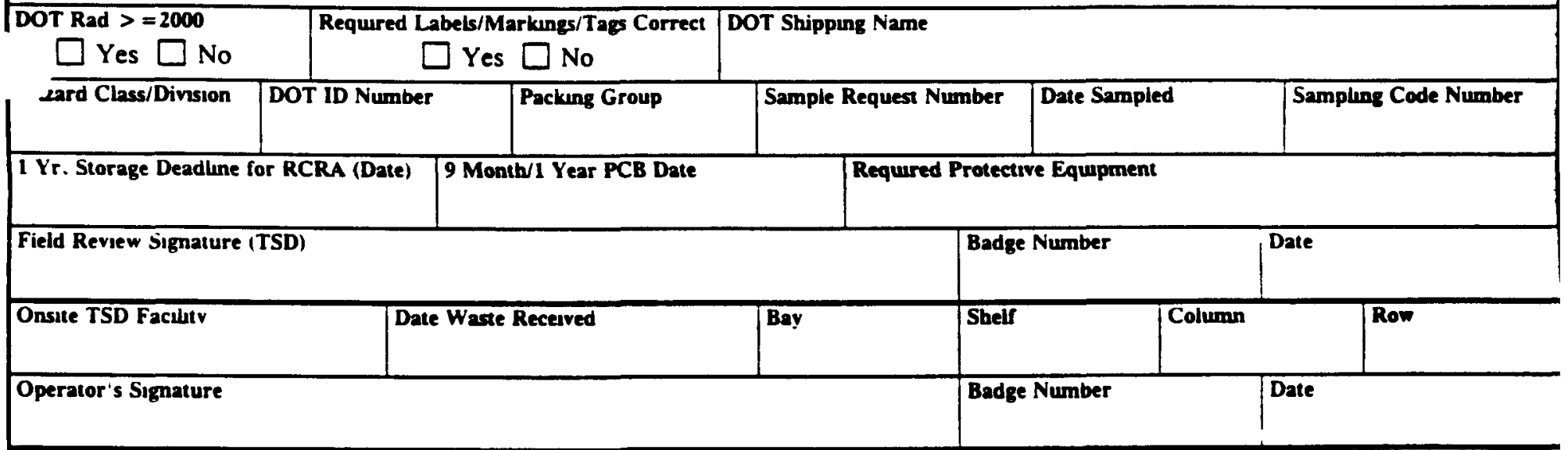

\begin{tabular}{|c|c|c|c|c|}
\hline \multicolumn{2}{|l|}{ Movement History } & \multicolumn{3}{|l|}{ Date Moved } \\
\hline 10 & 10 & & ; & : \\
\hline Operator's Signature & & & Badge Number & Date \\
\hline
\end{tabular}

Disposal Method/Code

Waste Manufest Number

Shupping Coordinator's Signature
Transporter's Name/Company

Waste Dertination
CD Receipt Date
Badge Number

Desposal Instructuons: 


\section{ENERGY SYSTEMIS WASTE DISPOSAL REQLEST}

\section{C. -2109 Pronite Sheet}

\section{WASTE ITEM IDEVTIFICATIOY}

II aste item ID Number The unique ID numeer ot tre udste item

Gonerator s Name The name ot the indiviuual responsioie tor the generation oi the uaste

Budge vo The badpe number of the waste generator

irenerator 5 Phisne vo Phone number unere une uaste generaior can be reacned

IS Vill btod

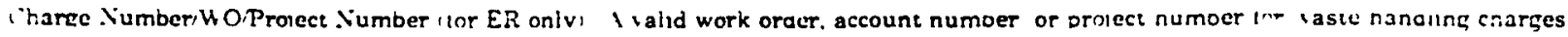

Origin Div The division code of the uriginaung division

Origin Date The date that the wasie was generated

Oriein site The site (plant) where the uaste was generated

Origin Facilitv The tacilitv (building) where the waste was ge ated

Origin Room/Ares The room or area where the waste was g: sted

2 Radiological Area The generation area is a radiological area wes or nol

113 Est Net Volume The estimated net volume of the waste material

114 Uniss Volume uniss

IIS Est Gross Weight The estumated gross weight of the waste matertal

116 Lnis Weight unis

\section{CONTANER INFORMATION}

(1) Cuntainer ID No The unique ID number of the shipping/storage conuaner for this waste ttem

C2 Conbiner Type The type code for the shipping/storage contaner

C3 Holding Site The site (piant) where the waste was held durtng accumulation

C4 Hoiding Facility The facility (building) where the waste was held during accumulation

Cs Holding Room/Area The room number or area identitier where the waste was held during accumulation

\section{WASTE CATEGORY}

HI Process stream ID The ID number of the orocess stream which generated une waste

W2 Process Category The category of the process whicn generated this waste

W3 Process Activiry The descriptive name of the generation process

W4 Phrsical Furm The physical form of the waste material

W5 Material Trpe The sub-category of the phvsical form of the waste material

W6 AW 4 Number tsbestos Work Auchorization Number

W7 Waste Descriotion Further specification of the waste, inciuding descriptive iniormation

H\& $U_{\text {aste Category Specific categories lor the waste material (checx eash une etcher YES }}$ or $_{\mathrm{V}^{*}}$ )

\section{CHEMICAL WASTE}

M1 RCRA (Y/N)? The waste contains RCRA regulated material

M2 RCRA 90-Dav Stan Date The date RCRA waste was placed in a 90-day storage area

M3. PCB $(Y / N)$ ' The waste conuins PCB regulated material

M4 PCB Surt Date The date PCB waste material was removed from service

M5 PCB Conc (PPM) The PCB concentration in parts per million (if -iess than nnn. enter nnn

M16 Ditermination Method The mechod used 10 determine the chemical characteristics

17 Determination Document Numberis) Document numbers that substantiate the determination of the characteristics

18 Flash Point The fiash point of the waste material idegrees $\mathrm{C}$ )

19 rit The relative acidirv of the waste material (pH)

110 EPA Waste Code Numbers The EPA waste code numbers determined from the waste characteristics

11 Substance ID The ID number of a chemical consument of the waste ictither is CAS number or MSDS record number

YI2 $\mathrm{Vol} \%$ The percent oy volume for the chemical subsance

113 Subsance Name The common name of the chemical subsunce

\section{RADIOACTTE WASTE}

Rl Rad Category The adioactuve waste categorv code (check one)

R2 Rad Handing Type the radioacuve waste nanding code

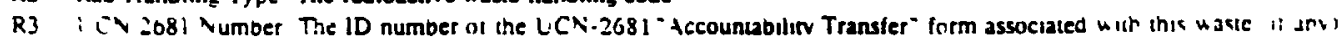

R4 Determination Method The meinod used to determine the radioactive characteristics (check one)

RS Determination Document Number(s) Document numbers that substantiate the detcmination of une characteristics

R6 (hemical Furm The chemical form of the waste material

R7 lsotode ID The ID number ot a particular radioactive isotope conianed in this waste tem

i8 Fal Ouanutv The esumated quantity of this isotope

R9 Uuan Lnits The units ior the isotope quantity (grams or curies)

\section{HANDI.FNG INFOR.MATION}

H1 Ilanding instructions General handing instructions for the waste

H2 Respirator Respirator recuirements tor handing this wasie

H3 Cartridge Type Respitator cartridge type to be useo (If appiscabie)

H4 HP Surver Dab (completed by Health Physics technician)

HP Tag Color The color code of the survev ag (G Y R.B)

Surtace Contamination The transterrable and Direct Reading count rates (dpm/100 cm2)

Dose Rate at Surtace The dose rate measured at the surtace (mrem/hr)

Dose Rate ai I Meter The dose rate measured at I meter imrerm/hr)

instrument ID The health physies instrument ID number (" $\mathrm{M}$ " number) Example M123456

H5 Pickup Site The site iplani) where the wasse is to be picked up

H6 Pickup facility The tacility (building) where the waste is to be picked up

H7 Pickup Room/Area The room number or atea identufier where the waste is to be picked up

\section{SIGNATURES AVD APPROVALS}

S1 Generator The sienature of the waste generator. cerufving tiat the information on the form is complete and accurate

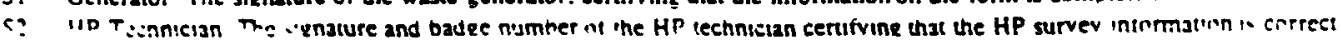

53 Vermication Officer The signature and badze number of an authorized person cerurying that une lorm nas neen cimpiecal properiv

S4 Derivative Classifier Determines the waste tem securiv classification and revifofote form for ciassified information 
Waste Stream ID

Date Request Initiated

Pick-Up Facility ID

Contact Name

Material Form (Circle one) SOLID GAS

Waste Stream Description
WTP Request No.

Date Request Rec.

Generator Division/Plant Phone No.

SLUDGE LIQUID
Badge No.

AEROSOL OIL

Contaminants (Circle one) ASBESTOS/BERYLLIUM/CARCINOGEN/MERCURY/PCB/OTHER Radioactive [] Yes [] No If Yes, [] Depleted [] Enriched

RCRA [] Yes []No (If Yes List Codes)

Respirator Required [] Yes [] No If Yes. [] Mask [] Cartridge

H.P. Tag Color

Total No. of Containers

Charge No.

\section{FIEID REVIEW}

Environmental TC

Badge No.

Date Assigned

Date of Field Review

Hazards

Hazard Class

DOT Name

Request rejected [] Yes [] No If Yes, Reason and Date

\section{SAMPLING HISTORY}

WTP PSM \#

LIMS No.

LIMS No.

Code No.

LIMS No.

Code No.

Code No.

LIMS No.

Code No.

Date
Date
Date
Date

\section{MOVEMENT HISTORY}

WTP Movement No.

Delivery Site

Transporter's Signature

Transporter's Signature

Environmental TC Signoff

Delivery Date

Badge No.

Badge No.

Location

Movement No.

Delivery Site

Transporter's Signature

Transporter's Signature

Environmental TC Signoff

Delivery Date

Badge No.

Badge No.

Location

\section{DISPOSAL INFORMATION}

WTP Movement No.

Disposal Facility

Facility Operator (Signature and Badge No.

Driver's Signature

Driver's Signature

Tank No.

Date

Badge No.

Date

Badge No.

Date 


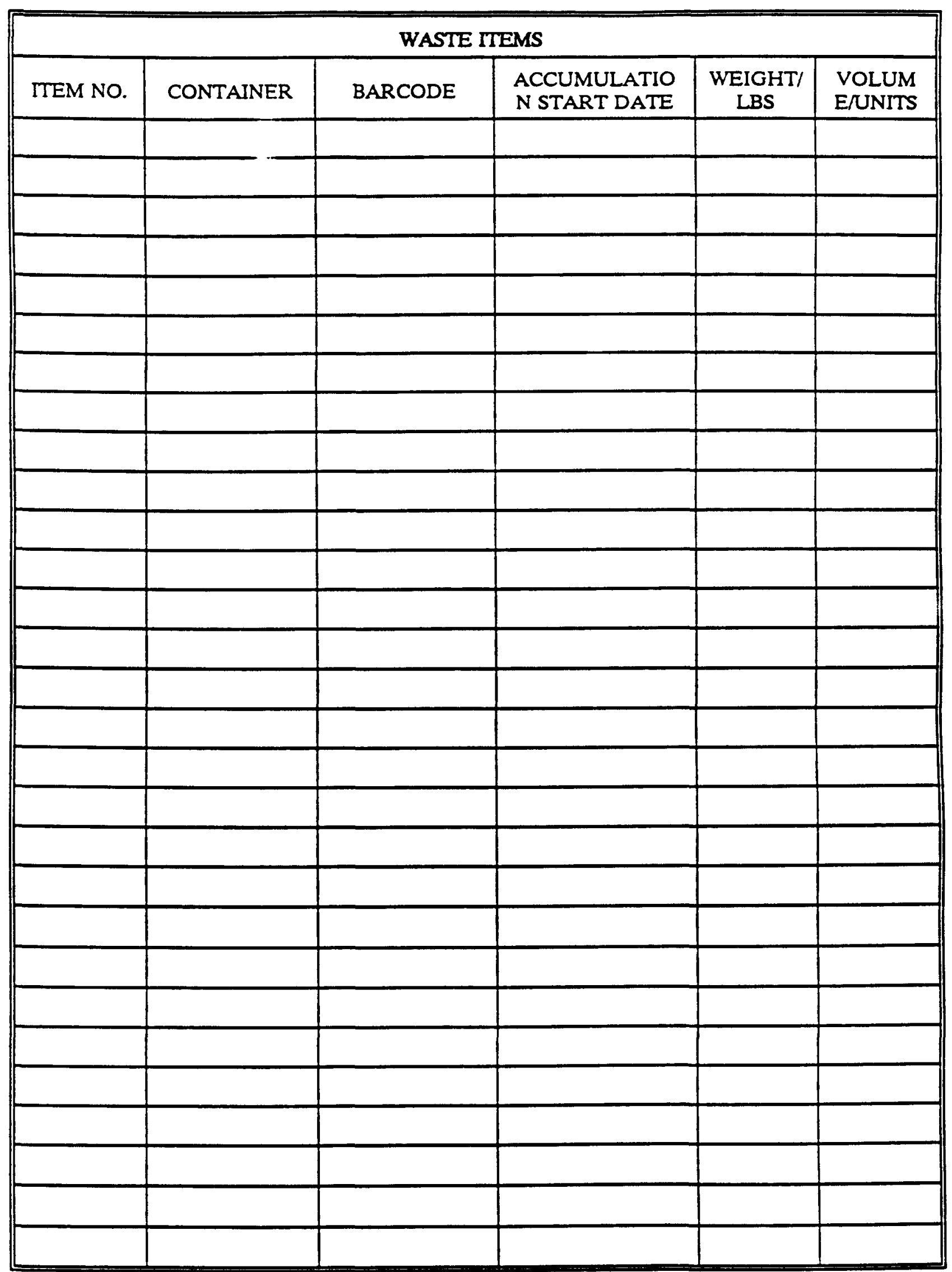




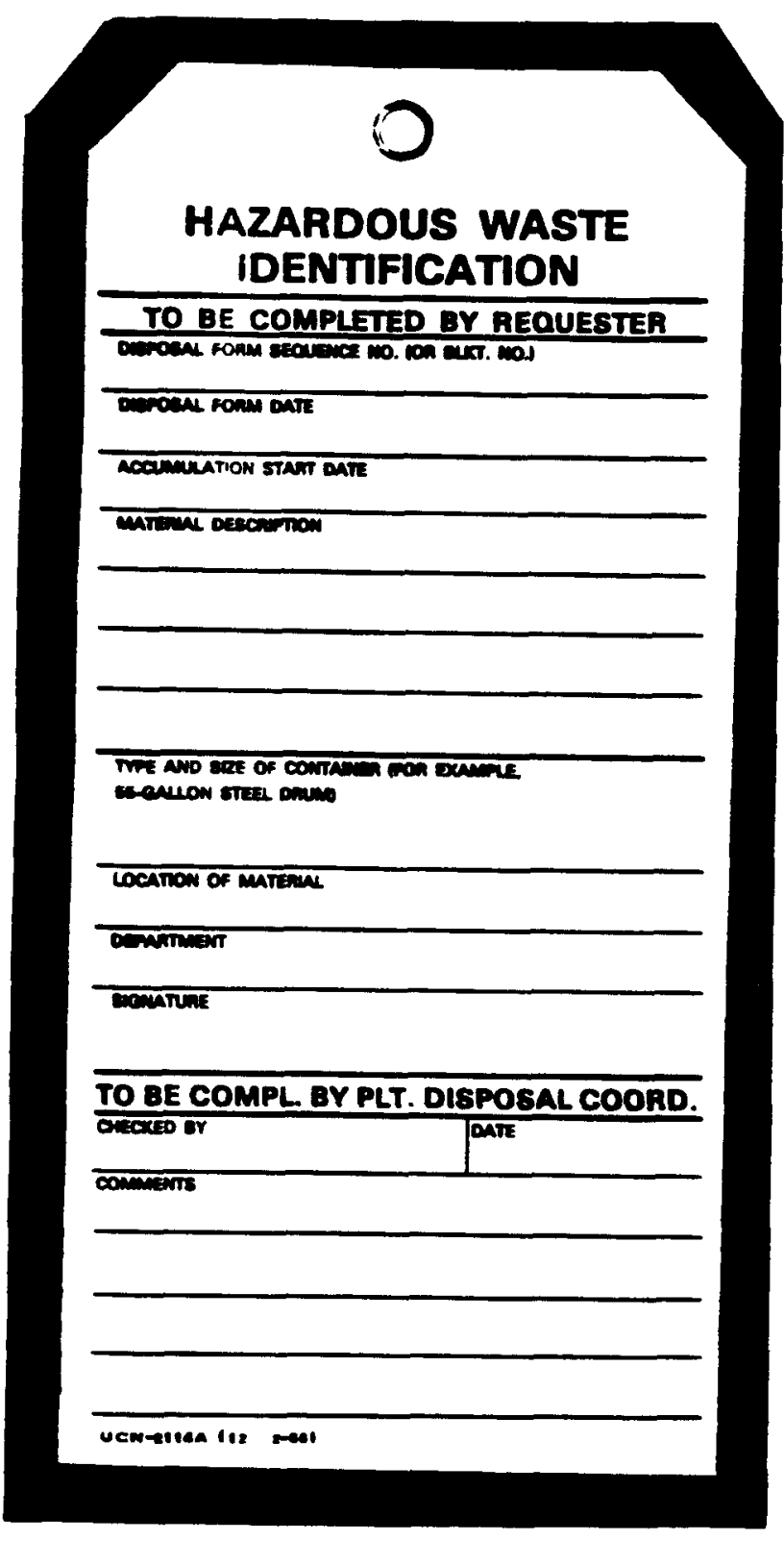

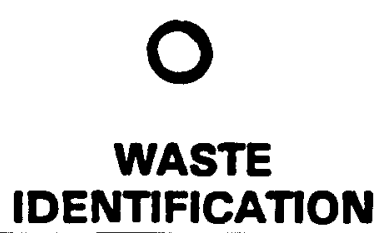

TO BE COMPLETED BY REQUESTER oisfosul rown seovence Mo. ton art. no.)

Docosel Fond Dafe

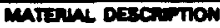

Tre and sor of compans fon Dxame ceanow strat onum

LocAmon of MATHAL

อะammin

erenarua

TO BE COMPL. BY PLT. DISPOSAL COOAD. arecros or DATe 


\section{SAMPLE REQUISITION REQUEST}

REQUEST OR CONTACT

REQUESTOR'S I.D. NO.

REQUESTOR'S PHONE NO.

MATERIAL DESCRIPTION

PICK-UP BUILDING

PICK-UP DOCK

CONTAINER TYPE

NO. OF CONTAINERS

SAMPLE REQUISITION NO. (LIMS)

SAMPLE CODE(S) SAMPLE DATE

QC SAMPLE CODE

RESPIRATOR REQUIREMENTS

DATE RESULTS REQUIRED BY

SAMPLING PLAN

C-2-8 


\section{APPENDDX C-3 \\ EXAMPLES OF POTENTIALLY INCOMPATIBLE WASTE}

Many hazardous wastes, when mixed with other waste or materials at a hazardous waste facility, can produce effects which are harmful to human health and the environment, such as (1) heat or pressure, (2) fire or explosion. (3) violent reaction, (4) toxic dusts, mists, fumes. or gases, or (5) flammable fumes or gases.

Below are examples of potentially incompatible wastes, waste components, and materials, along with the harmful consequences which result from mixing materials in one group with materials in another group. The list is intended as a guide to operators of storage facilities and to indicate the need for special precautions when handling and storing potentially incompatible waste materials. This list is not intended to be exhaustive.

In the list below, the mixing of a Group A material with a Group B material my have the potential consequences as noted.

Group 1-A

Acetylene sludge

Alkaline caustic liquids

Alkaline cleaner

Alkaline corrosive liquids

Alkaline corrosive battery fluid

Caustic wastewater

Lime sludge and other corrosive alkalines

Lime wastewater

Lime and water

Spent caustic
Group 1-B

Acid sludge

Acid and water

Battery acid

Chemical cleaners

Electrolyte, acid

Etching acid liquid or solvent

Pickling liquor and other corrosive acids

Spent acid

Spent mixed acid

Spent sulfuric acid

Potential consequences: Heat generation; violent reaction. 


\section{APPENDIX C-3 (Continued) \\ EXAMPLES OF POTENTIALLY INCOMPATIBLE WASTE}

Group 2-A

Aluminum

Beryllium

Calcium

Lithium

Magnesium

Potassium

Sodium

Zinc powder

Other reactive metals and metal hydrides

Potential consequences: Fire, explosion, or heat generation; generation of flammable or toxic gases.

Group 3-A

Alcohols

Water
Group 2-B

Groups 1-A or 1-B waste 


\section{APPENDIX C-3 (Continued) \\ EXAMPLES OF POTENTIALLY INCOMPATIBLE WASTE}

Group 4-A

Alcohols

Aldehydes

Halogenated hydrocarbons

Nitrated hydrocarbons

Unsaturated hydrocarbons

Other reactive organic compounds and solvents
Group 4-B

Concentrated waste

Groups 1-A or 1-B

Group 2-A wastes

Potential consequences: Fire, explosion, or violent reaction.

Group 5-A

Spent cyanide and sulfide solutions
Group 5-B

Group 1-B wastes

Potential consequences: Generation of toxic hydrogen cyanide or hydrogen sulfide gas.

Group 6-A

Chlorates

Chlorine

Chlorites

Chromic acid

Hypochlorides

Nitrates

Nitric acid, fuming

Perchlorates

Permanganates

Peroxides

Other strong oxidizers

\section{Group 6-B}

Acetic acid and other organic acids

Concentrated mineral acids

Group 2-A wastes

Group 4-A wastes

Other flammable and combustible wastes

Potential consequences: Fire, explosion or violent reaction. 



\section{APPENDIX}

D-2

SECONDARY CONTAINMENT

CALCULATIONS 



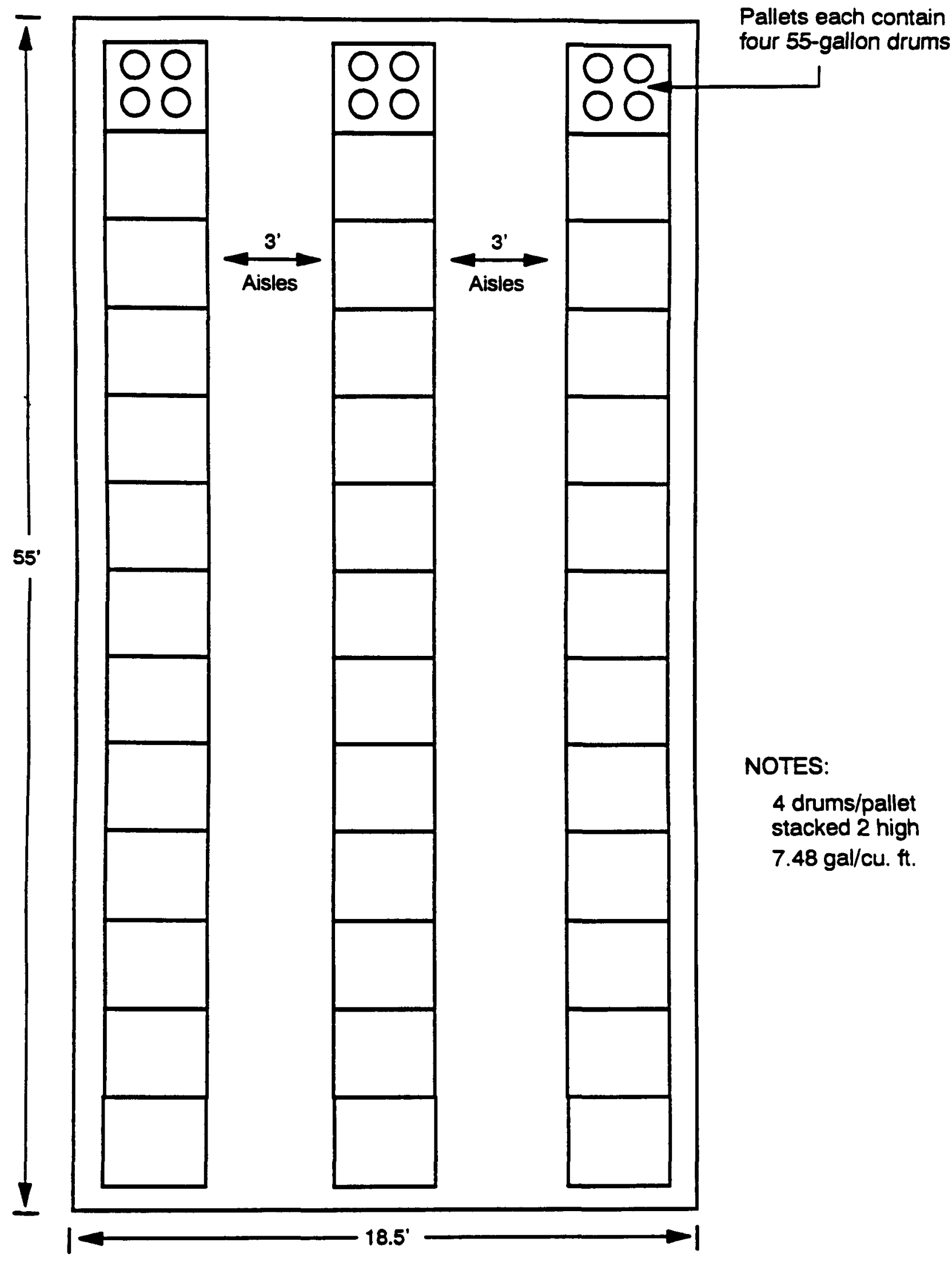

Building 9201-4 Container Storage Pallet Layout

D-2-1 


\section{Building 9201-4}
Area $=55^{\prime} \times 18.5^{\prime}$ with $6^{\prime \prime}$ roll over dike
Volume $=55^{\prime} \times 18.5^{\prime} \times 0.5^{\prime} \times 7.48 \mathrm{gal} / \mathrm{ft}^{3}=3,805.45$ gallons

Available volume

$3,805.45 \mathrm{gal}-39 \times 12 \mathrm{gal} / \mathrm{pallet}=3,337 \mathrm{gal}$.
$(468 \mathrm{gal})$

$\underline{3337}=33,370$ maximum $R C R A$ capacity in gallons

0.10

Actual volume to be stored based on

78 pallets - stacked two high with four 55-gallon drums on each

$78 \times 4 \times 55 \mathrm{gal}=17,160$ gallons 


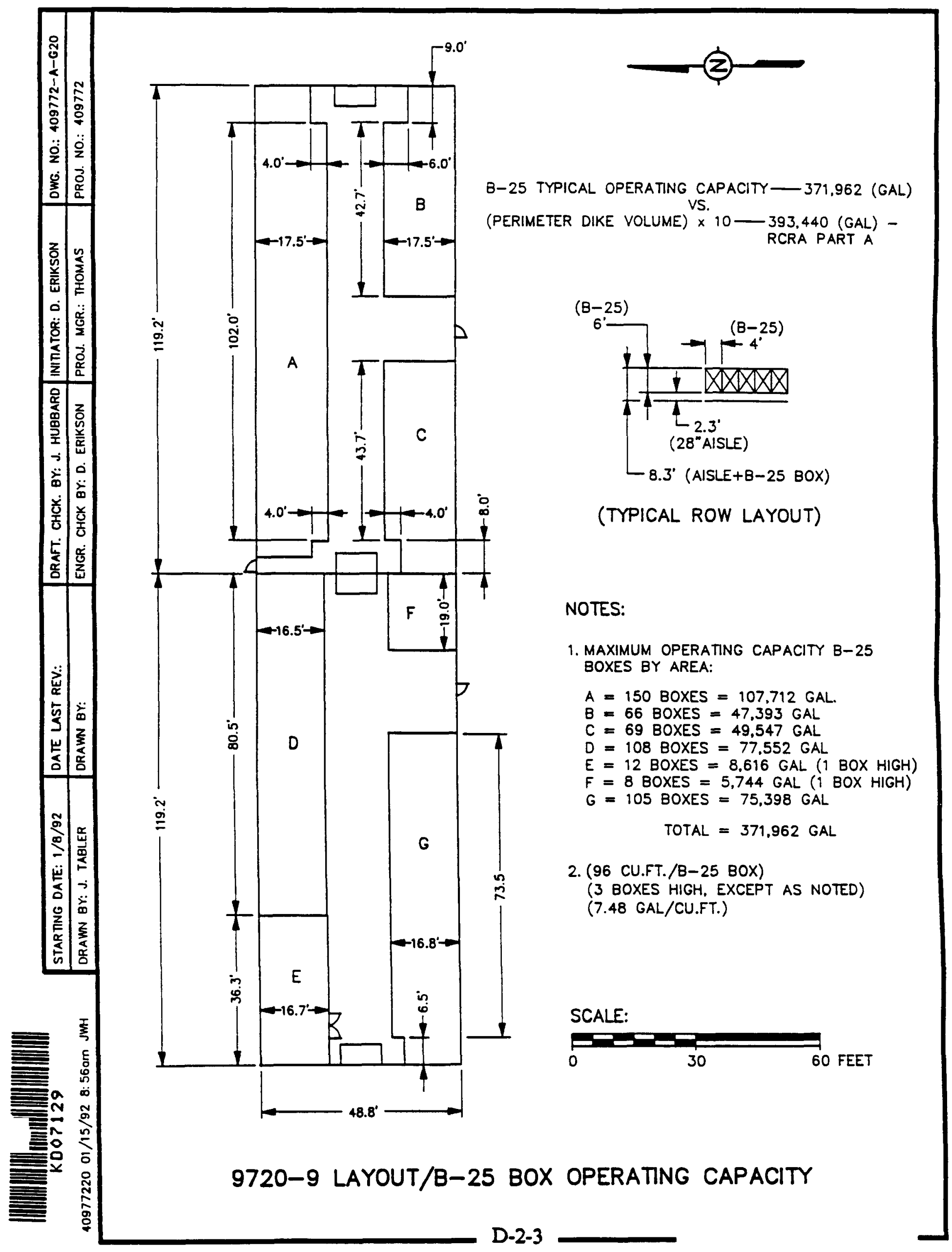


Building 9720-9

Dike Volume

East End

$119.2^{\prime} \times 48.8^{\prime} \times 0.5^{\prime}=2,908 \mathrm{ft}^{3}$

Available Volume

Total Volume - Obstructions $=$ Total Available Volume

4 ramps $=4\left(5^{\prime} \times 10^{\prime} \times 0.5^{\prime}\right) \times=50 \mathrm{ft}^{3}$

Pallets $128 \times 12$ gal/pallet $+7.48 \mathrm{gal} \mathrm{ft}{ }^{3}=205 \mathrm{ft}^{3}$

Total Available Volume $=2,908-50-205=2,653 \mathrm{ft}^{3}$

$2,653 \mathrm{ft}^{3} \times 7.48 \mathrm{gal} / \mathrm{ft}^{3}=19.844$ gallons

Maximum Proposed Permitted $=\frac{19,844 \mathrm{gal}}{0.10}=198,440$ gallons

0.10

Dike Volume

West End

$119.2^{\prime} \times 48.8^{\prime} \times 0.5^{\prime}=2,908 \mathrm{ft}^{3}$

Available Volume

Total Volume - Obstructions $=$ Total Available Volume

Obstructions

125 pallets $x 12 \mathrm{gal} /$ pallet $+7.48 \mathrm{gal} \mathrm{ft}^{3}=201 \mathrm{ft}^{3}$

ramps $=3\left(5^{\prime} \times 10^{\prime} \times 0.5^{\prime}\right) \times=37.5 \mathrm{ft}^{3}$

masonry walls $=62.5 \mathrm{ft}^{3}$

Total $=301 \mathrm{ft}^{3}$

Total Available Volume $=2,908 \cdot 301 \mathrm{ft}^{3}=2,607 \mathrm{ft}^{3} \times 7.48 \mathrm{gal} / \mathrm{ft}^{3}=19,500$ gallons

Maximum Proposed Permitted $=\frac{19,500 \text { gal }}{0.10}=195,000$ gallons 


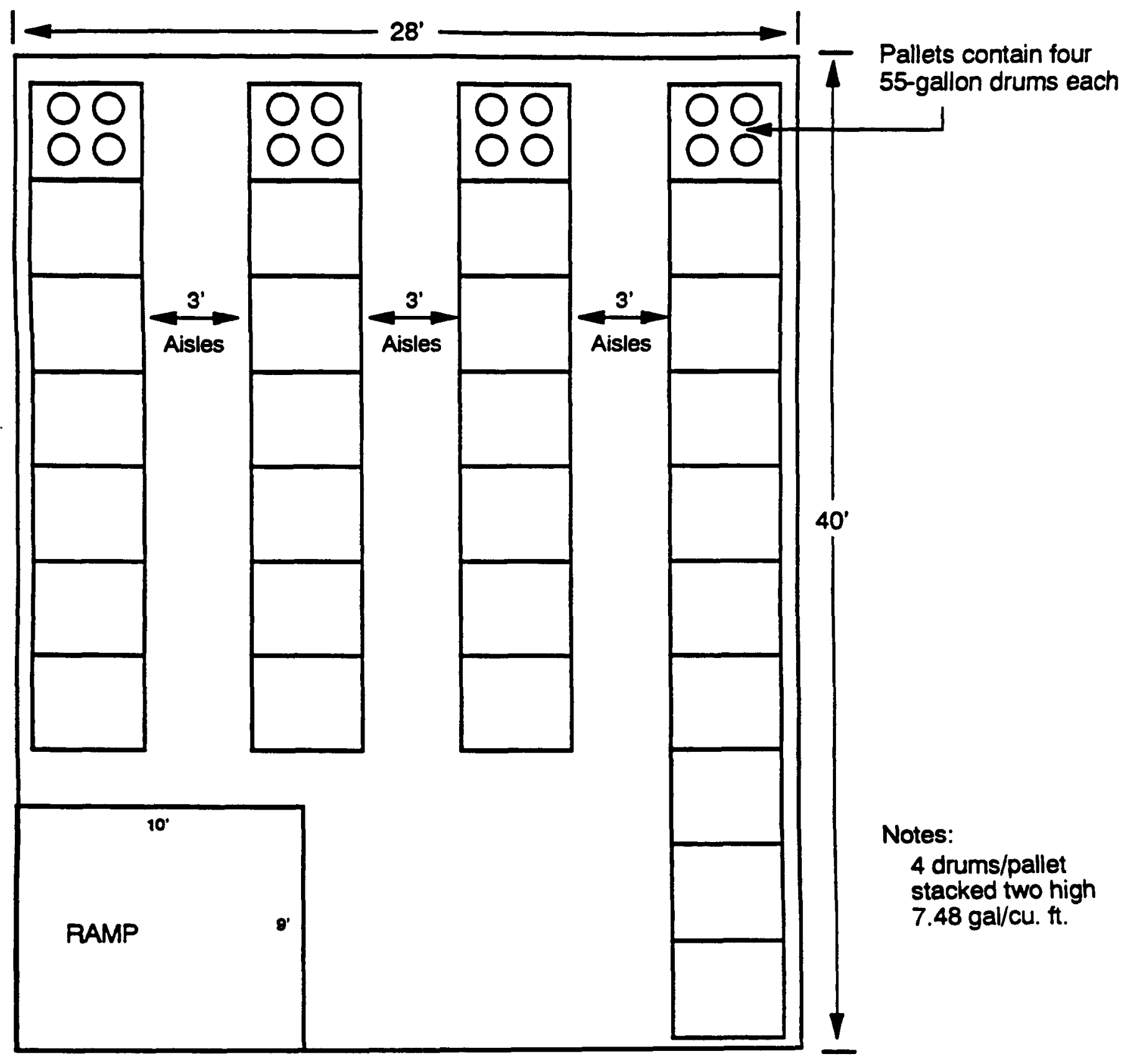

Dike Volume

$$
40^{\prime} \times 28^{\prime} \times .45^{\prime}-\left(10^{\prime} \times 9^{\prime} \times .225\right)=483.75 \mathrm{ft}^{3} \times \frac{7.48 \mathrm{gal}}{\mathrm{ft}^{3}}=3,618.5 \mathrm{gal}
$$

Available Volume

$$
\begin{aligned}
3,618.5 \mathrm{gal}-(31 \times 12 \mathrm{gal} / \mathrm{pallet})= & 3,246.5 \mathrm{gal} \\
& \frac{.10}{32,465 \mathrm{gal}} \text { RCRA Gallon Capacity }
\end{aligned}
$$


Page 1 of 2

\section{BLDG. 9720-31 DIKE CAPACITY FOR TDEC PERMIT}

\section{CALCULATION FOR PERMITTED CAPACITY}

Assumptions: Calculations are based on a storage room dike dimension of $141 / 2^{\prime} \times 30^{\prime} \times 0.5^{\prime}$

Calculations are based on staging room dike dimensions of $101 / 2^{\prime} \times 30^{\prime} \times 0.5^{\prime}$

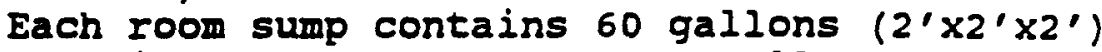

1 cubic foot of water $=7.48$ gallons

All Storage rooms are exactly the same

All staging rooms are exactly the same

Pallet displacement $=12$ gallons

Dimensions are based on actual measurements

Actual liquid capacity of each of the seven storage rooms:

$\left(14.5^{\prime}\right)\left(30^{\prime}\right)\left(0.5^{\prime}\right)=217.5$ cubic feet

217.5 cubic feet +8 cubic feet (sump) $=225.5$ cubic feet

(225.5 cubic feet) $(7.48$ gallons/Cu. ft. $)=1686.7$ gallons

Actual liquid capacity of each of the seven staging rooms:

$\left(10.5^{\prime}\right)\left(30^{\prime}\right)\left(0.5^{\prime}\right)=157.5$ cubic feet

157.5 cu. ft. +8 cu. ft. (sump) $=165.5$ cubic feet

$(165.5$ cu. ft. $)(7.48 \mathrm{gal} / \mathrm{cu} . \mathrm{ft})=$.1237.9 gallons

The maximum number of drums that can be reasonably stored in each of the rooms are as follows:

Storage Rooms $=96$ drums double stacked (12 pallets/layer)

Staging Rooms $=20$ drums double stacked ( 3 pallets on floor)

Volume displaced by pallets in storage rooms:

(12 pallets)(12 gal/pallet) $=144$ gallons

Volume displaced by pallets in staging rooms:

( 3 pallets) $(12 \mathrm{gal} / \mathrm{pallet})=36$ gallons

Usable secondary containment volumes in each of the RCRA Motel rooms:

Storage rooms $=1686.7 \mathrm{gal}-144 \mathrm{gal}=1542.7 \mathrm{gal}$

staging rooms $=1237.9 \mathrm{gal}-36 \mathrm{gal}=1201.9 \mathrm{gal}$ 
Loading capacity of each storage room $=96$ drums or 5280 gallons Loading capacity of each staging room $=20$ drums or 1100 gallons

( 7 storage rooms) ( 5280 gallons) $=36,960$ gallons

(7 staging rooms) (1100 gallons) $=7700$ gallons

Total actual drum storage $=44,660$ gallons

Small quantity storage on staging room shelves $=1340$ gallons (estimate)

Total permitted capacity of $9720-31$ should be set at 16,000 gallons

The permit capacity of 46,000 gallons meets the 10 secondary containment capacity required by TDEC Rule Chapter 1200-1-11.06(g)(f).

Calculations performed by

K.H. Cooper h. A. Corpen $12 / 12 / 91$

9720-31 Facility Engineer 
BUILDING 9720-31, RCRA and MIXED WASTE STORAGE and STAGING
CONTAINER MANAGEMENT LAYOUT

Siorage Capactucs per Storage Room

(Typical storage layout for storage room)

Double stacked/28" arstes

96 Druma

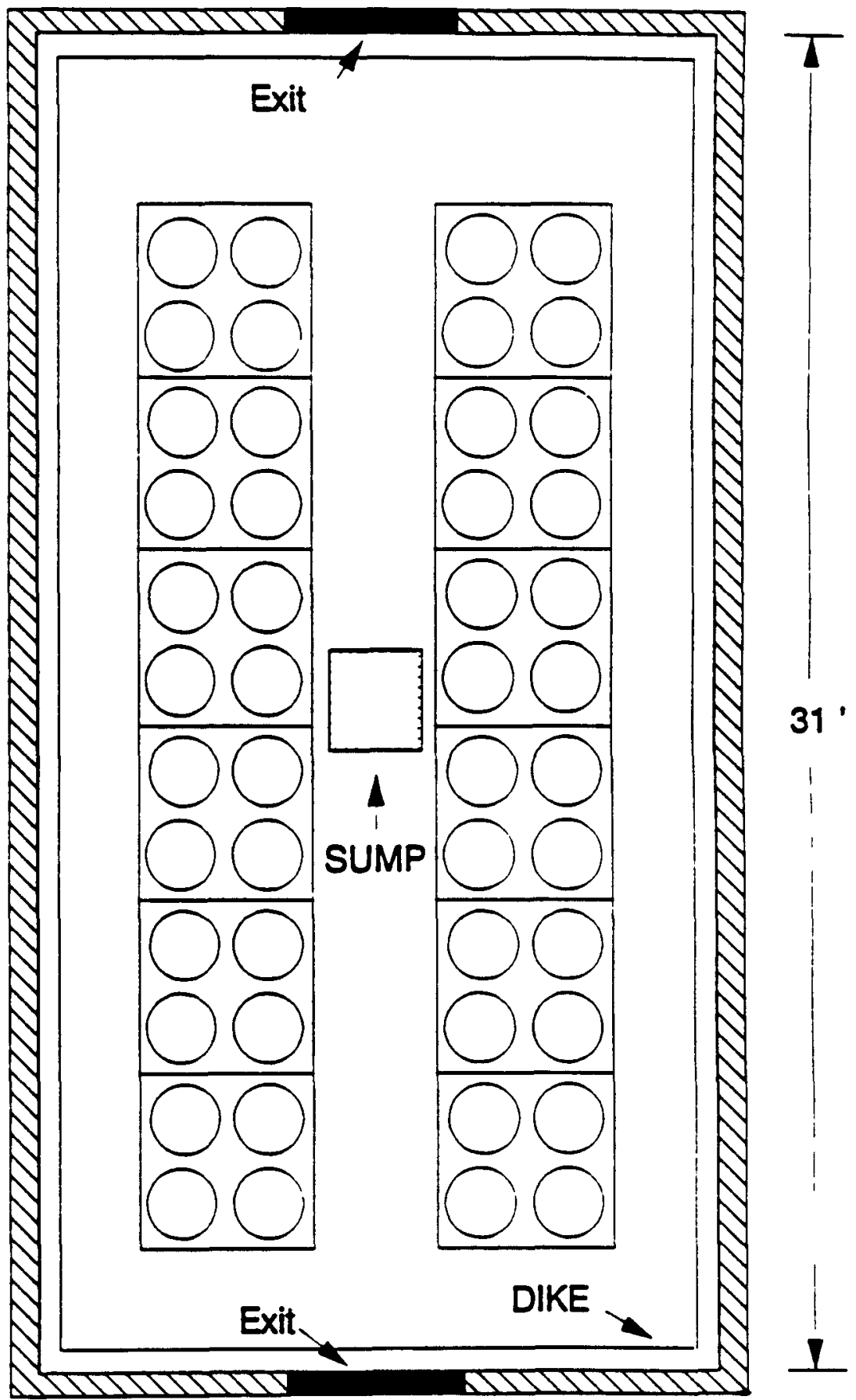

$151 / 2^{\circ}$ 


\section{BUILDING 9720-31, RCRA and MIXED WASTE STORAGE and STAGING CONTAINER MANAGEMENT LAYOUT}

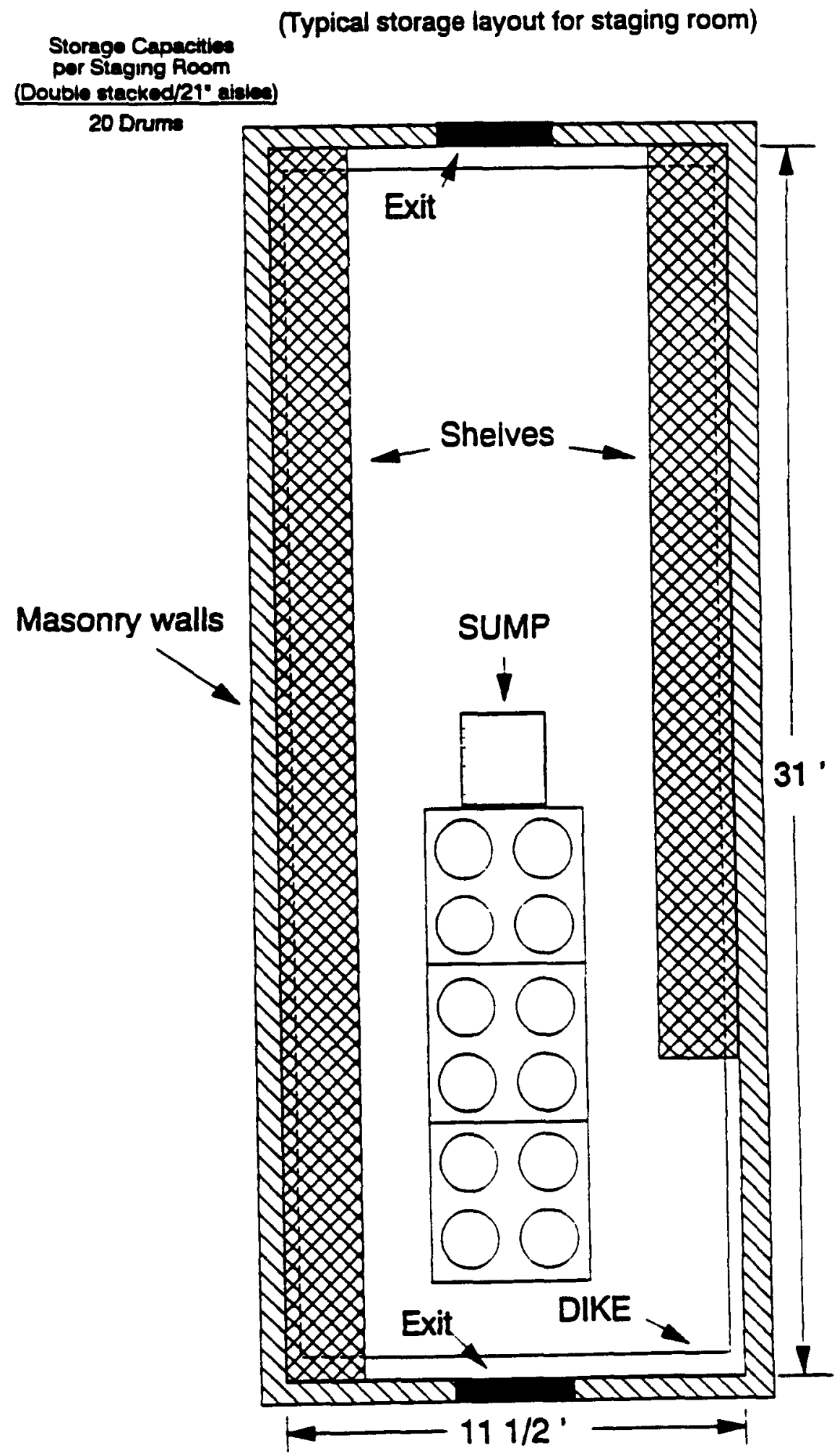



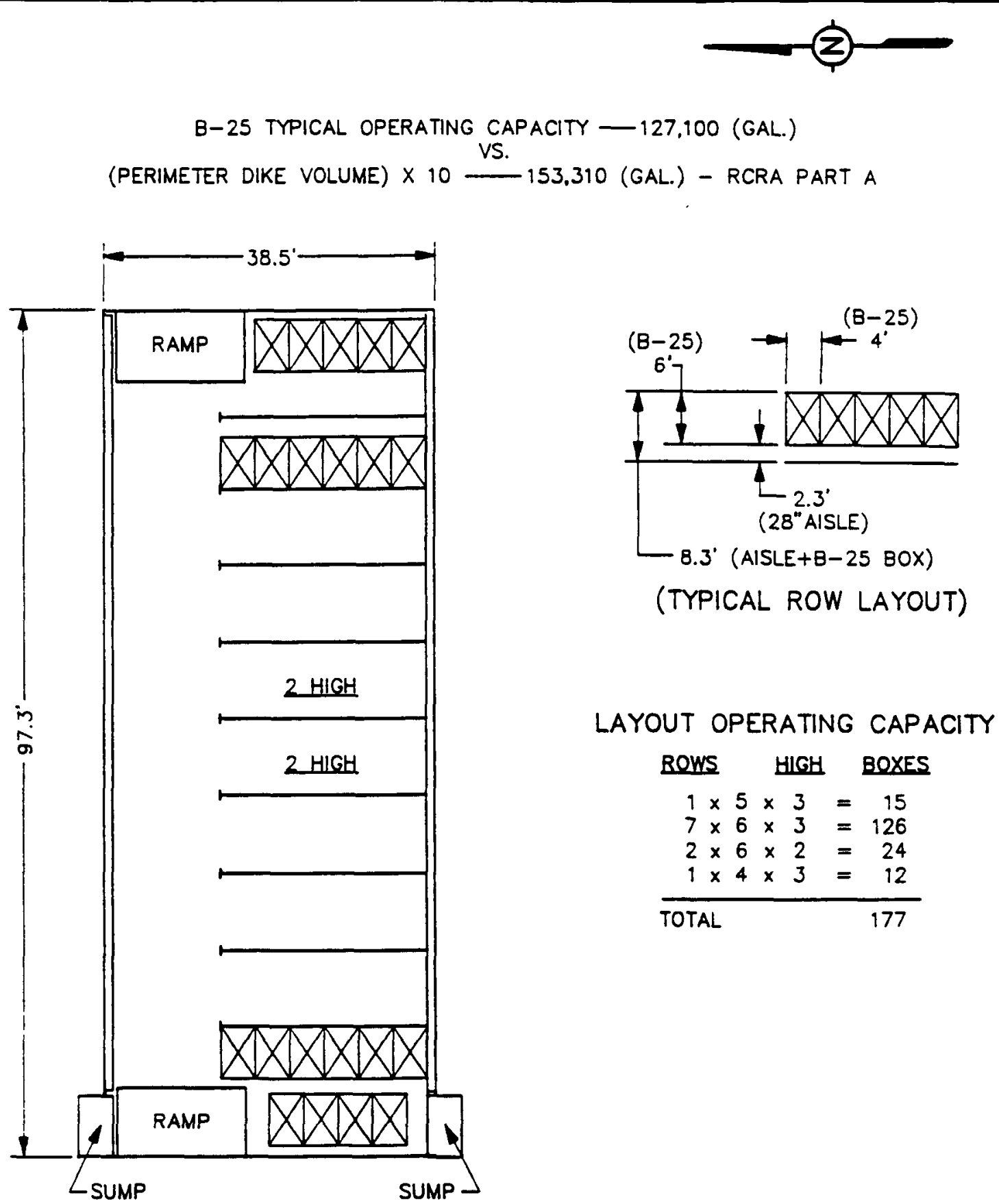

$(177 \times 96 \times 7.48)=127,100($ GAL), LAYOUT OPERATING CAPACITY

SCALE:

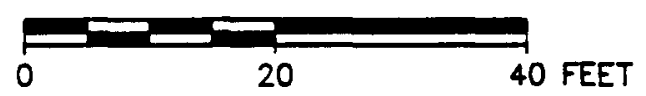

NOTES:

(96 CU.FT./B-25 BOX)

( 3 BOXES HIGH, EXCEPT AS NOTED) (7.48 GAL/CU.FT.) 
Building 9720-58

Dike Volume

$97.3^{\prime} \times 36.5^{\prime} \times 5 / 12^{\prime \prime}=1,479 \mathrm{ft}^{3}$

+2 troughs

$2 \times 89.3^{\prime} \times 1.0^{\prime} \times 14 / 12^{\prime \prime}=208 \mathrm{ft}^{3}$

+2 sumps

$2 \times 7.1^{\prime} \times 6.3^{\prime} \times 7.0^{\prime}=626 \mathrm{ft}^{3}$

Total Like Volume

$1,479 \mathrm{ft}^{3}+208 \mathrm{ft}^{3}+626 \mathrm{ft}^{3}=2,313 \mathrm{ft}^{3}$

less obstructions

2 ramps $=2 \times 8.5^{\prime} \times 15^{\prime} \times=127 \mathrm{ft}^{3}$

87 pallets $=87 \times 12$ gallon $/$ pallet $+7.48 \mathrm{gal} / \mathrm{ft}^{3}=139 \mathrm{ft}^{3}$

Total Available Volume $=2,313 \mathrm{ft}^{3}-127 \mathrm{ft}^{3}-139 \mathrm{ft}^{3}=2,047 \mathrm{ft}^{3}$ $2,047 \mathrm{ft}^{3} \times 7.48 \mathrm{gal} / \mathrm{ft}^{3}=15,331$ gallons

Maximum Proposed Permitted $=\frac{15,331 \text { gal }}{0.10}=153,310$ gallons 


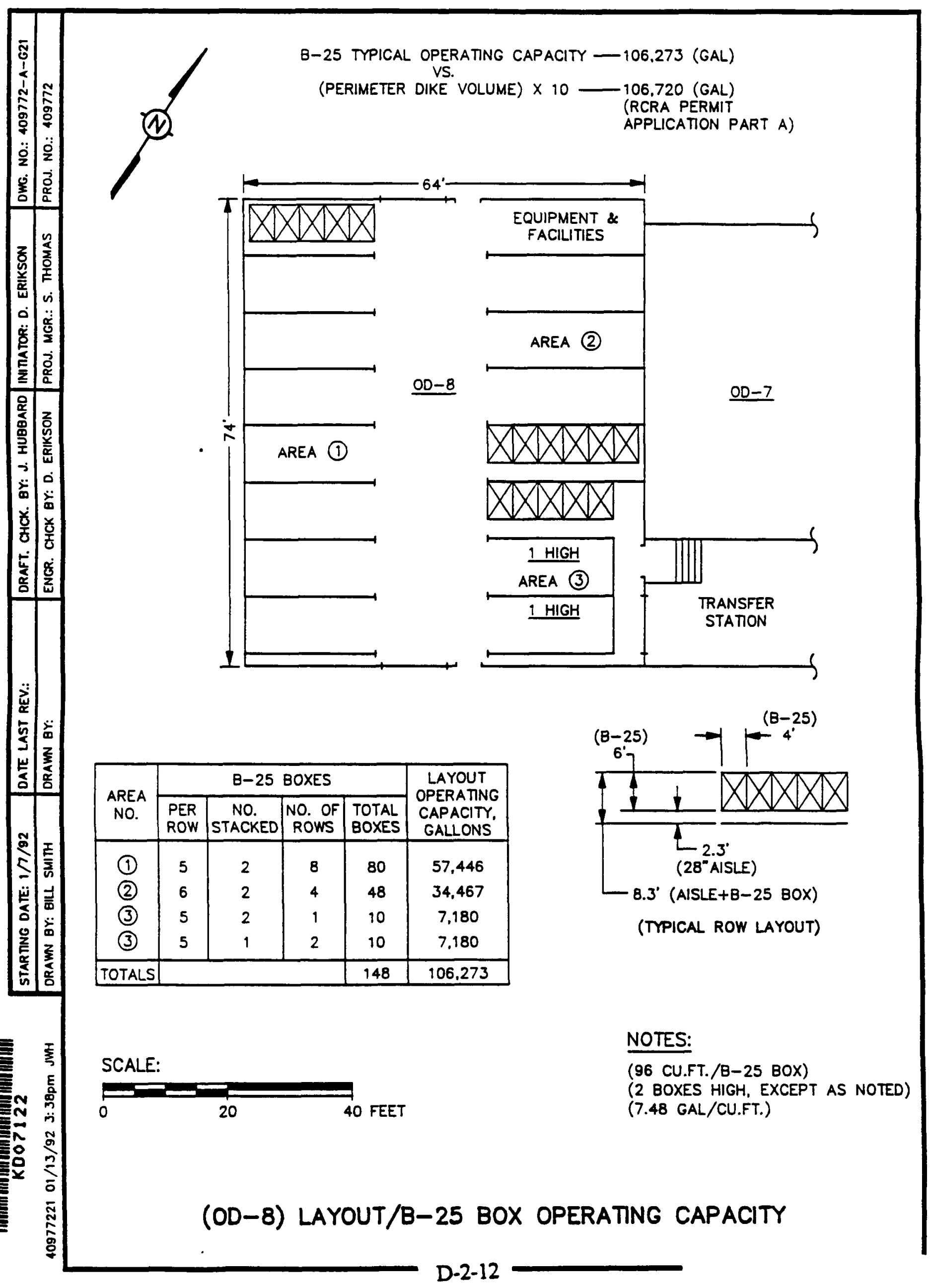


Building 9811-1 (OD-8)

Dike Volume

$74^{\prime} \times 64^{\prime} \times 0.35^{\prime}=1,657.6 \mathrm{ft}^{3}$

Sump Volume $=\left(2.3^{\prime} \times 2.3^{\prime} \times 2^{\prime}\right) \times 2=\underline{21.16 \mathrm{ft}^{3}}$

Total Dike Volume $=1,678.76 \mathrm{ft}^{3}$

\section{Available Volume}

Total Volume - obstructions $=$ Total Available Volume

\section{Obstructions}

$$
\begin{aligned}
& 144 \text { pallets } \times 12 \text { gallons/pallet }+7.48 \mathrm{gal} / \mathrm{ft}^{3}=231 \mathrm{ft}^{3} \\
& 2 \text { ramps }=2\left(3.5^{\prime} \times 12^{\prime} \times \quad \times 0.35^{\prime}\right)=14.7 \mathrm{ft}^{3} \\
& 4 \text { pillars }=4\left(3 \times 1.5^{\prime} \times .35^{\prime}\right)=6.3 \mathrm{ft}^{3} \\
& \text { Total Obstructions }=252 \mathrm{ft}^{3}
\end{aligned}
$$

Total Available Volume $=1678.76 \mathrm{ft}^{3}-252 \mathrm{ft}^{3} \times 7.48 \mathrm{gal} / \mathrm{ft}^{3}=10.672 \mathrm{gal}$

Maximum Proposed Permitted $\underline{10,672}=106,720$ gallons

$$
0.10
$$




\section{CWSA DIKE CAPACITY FOR TDEC PERMIT}

\section{CALCULATION FOR PERMITTED CAPACITY}

Assumptions: Actual liquid level at West end of center dike $=0$ inches

Actual liquid level at East end of center dike $=12$ inches

1 cubic foot $=7.48$ gallons

sump contains 8 cubic feet ( 60 gallons)

All three containment dikes contain equal amount (conservative)

Aisle width between rows of waste $=28$ inches

Maximum number of pallets per stacking layer $=171$ pallets

Pallet displacement $=12$ gallons $/$ pallet

B-25 boxes are filled to a maximum of $90 \%$

B-25 dimensions are 4'x6' $\times 4$ ' (volume of 96 cubic feet)

Actual liquid capacity of CWSA Center dike: $1 / 2 b h l+$ sump capacity

$(1 / 2)(168 \mathrm{ft})(1 \mathrm{ft})(48 \mathrm{ft})=4032$ cubic feet

(4032 cubic feet) $(7.48$ gal/cubic foot $)=30159.4$ gallons

$30159.4 \mathrm{gal}+60 \mathrm{gal}=30219.4$ gallons

Calculation for permitted dike capacity. (Actual capacity - displacement)(10)

$30219.4-(171$ pallets $)(12$ galpallet $)=28167.4$ gallons

$(28167.4 \mathrm{gal})(10)=281,674$ gallons per dike

Calculations for total facility permitted capacity $=($ dike capacity $)(3)$

$$
(281,674 \mathrm{gal})(3)=845,022 \text { gallons }
$$

Maximum loading of drums would be 2052 drums (triple stacked) or 112,860 gallons per dike.

Maximum loading of B-25 boxes would be 411 boxes (triple stacked, $90 \%$ filled) or 265.618 gallons of waste.

To be conservative, 810,000 gallons ( 270,000 gallons/pad) will be used as the facility's RCRA permitted capacity. 


\section{Rain water run-on control:}

Drum capacity per pad $=2052$ drums

Liquid capacity of drums $=(2052 \mathrm{drums})(55 \mathrm{gal} / \mathrm{drum})=112,860 \mathrm{gallons} / \mathrm{pad}$

Each CWSA dike is required to contain at least $10 \%$ of the stored liquid waste or 11,286 gallons. Calculated actual dike capacity - pallet displacement $=28,167.4$ gallons

Excess capacity $=28,167.4 \mathrm{gal} \cdot 11,286 \mathrm{gal}=16,881.4 \mathrm{gal}$

Therefore, there is sufficient excess capacity in each dikes secondary containment volume to handle rain water run-on until detected and removed per TDEC Rule Chapter 1200-1-11.06(9)(f).

Calculations performed by
KH. Cooper
CWSA Facility Engineer 


\section{CWSA CENTER DIKE LIQUID CAPACITY AT OVERFLOW}

(Actual level noted during leak testing)

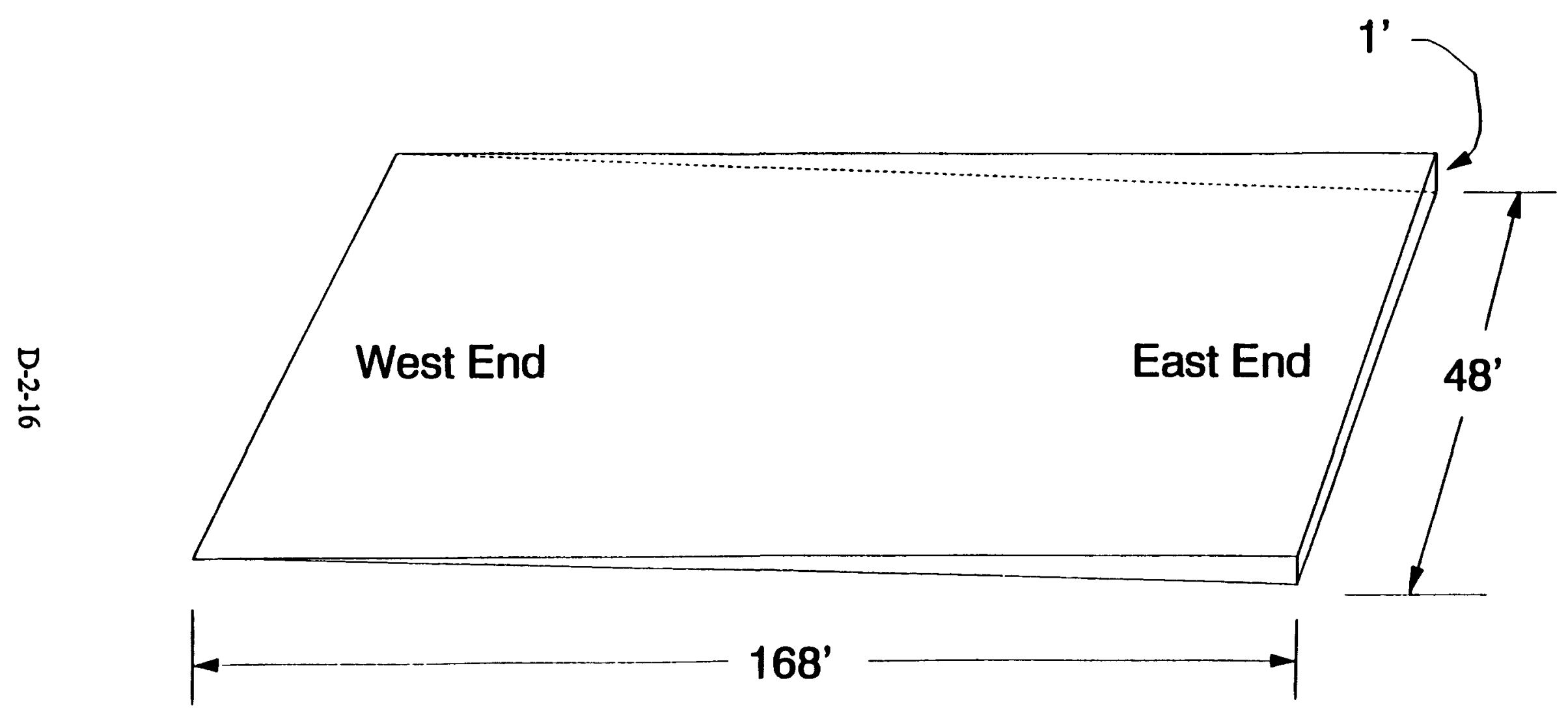




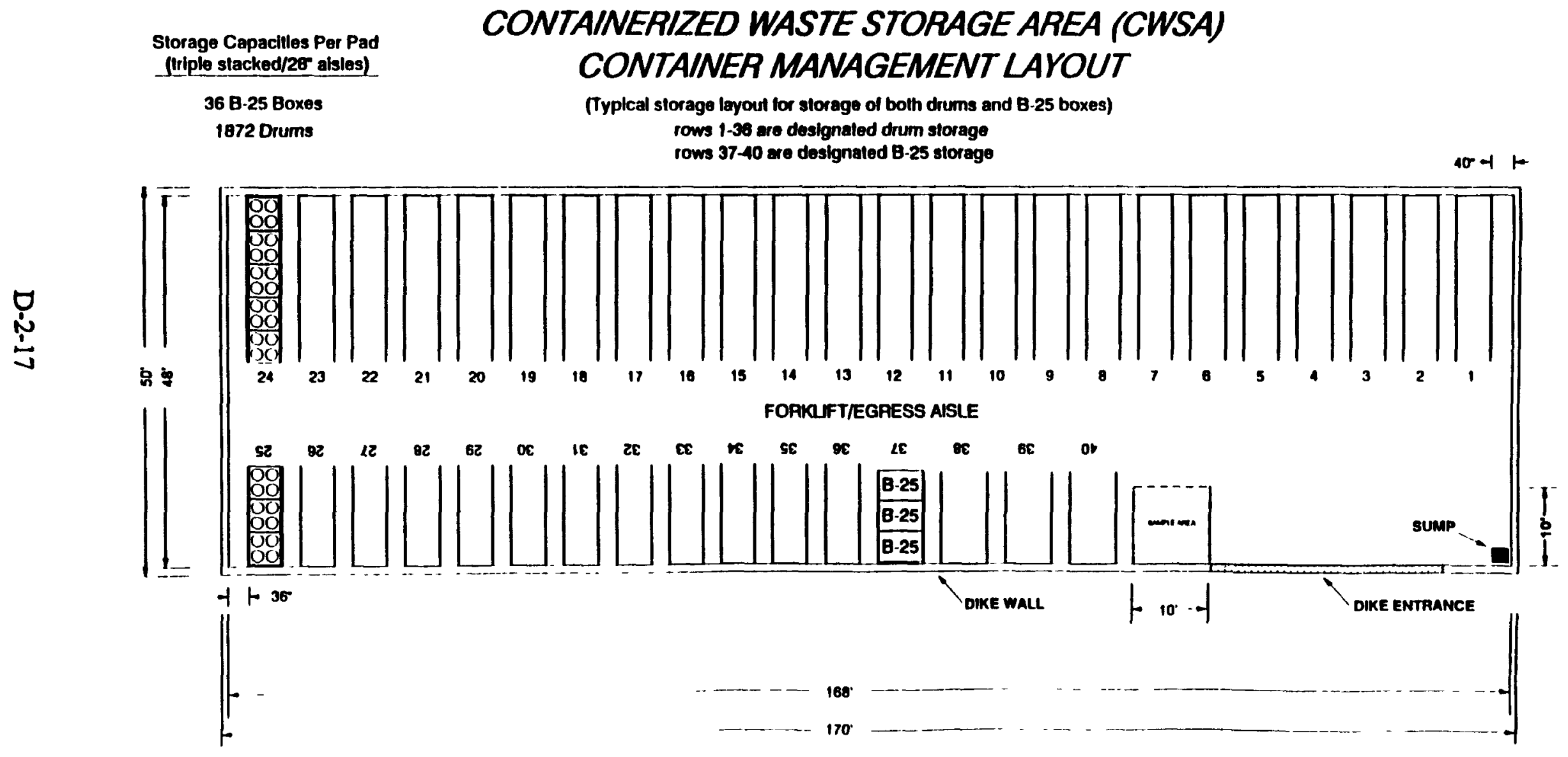


Storage Capactiles Per Pad

(triple slacked/28" alsles)

2052 Drums (112,860 Gal)

\section{CONTAINERIZED WASTE STORAGE AREA (CWSA)}

CONTAINER MANAGEMENT LAYOUT

(Typlcal layout for maximum drum loading)

$40-15$
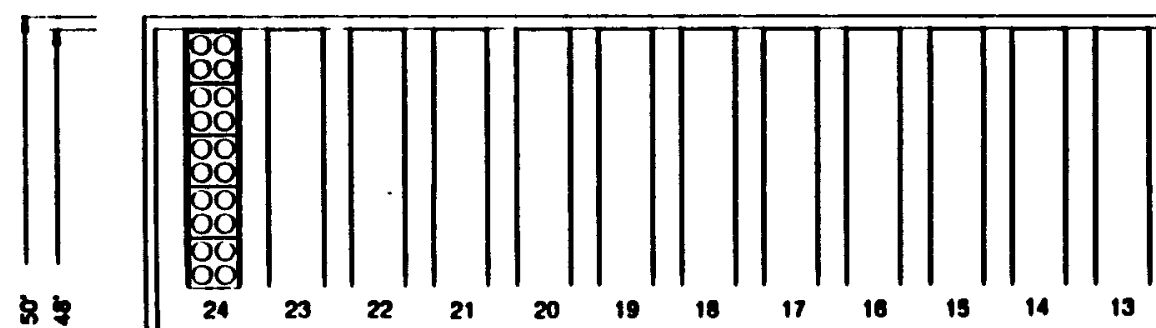

8

FORILFT/EGRESS AISLE
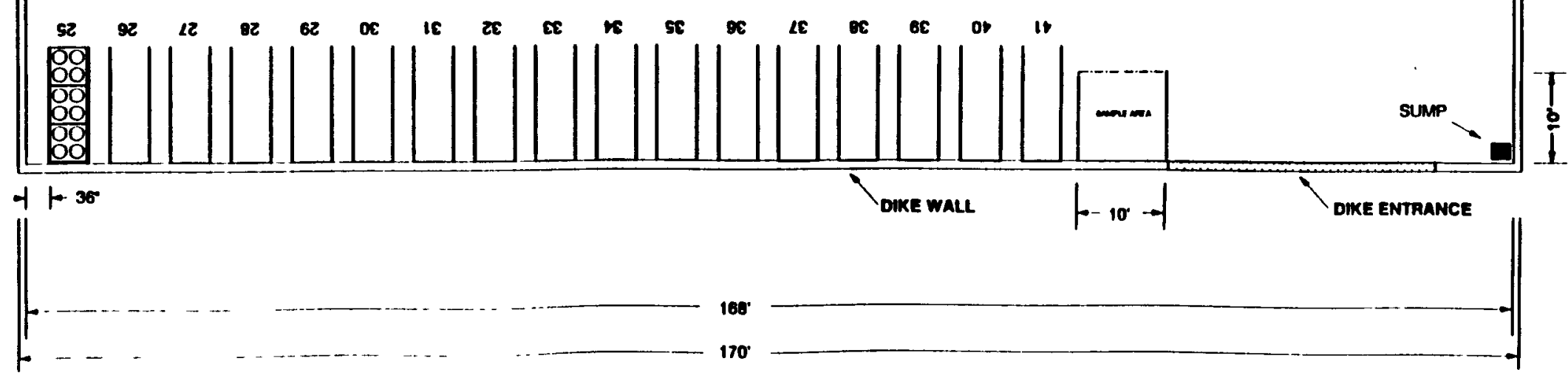
Storage Capactiles Per Pad (tiriple stacked/28 aisles)

\section{B-25 Boxes (90\% Fum)} (Approx. 265,600 Gal)

\section{CONTAINERIZED WASTE STORAGE AREA (CWSA)} CONTAINER MANAGEMENT LAYOUT

(Typical loyout for maximum 8-25 loading)

ثั่

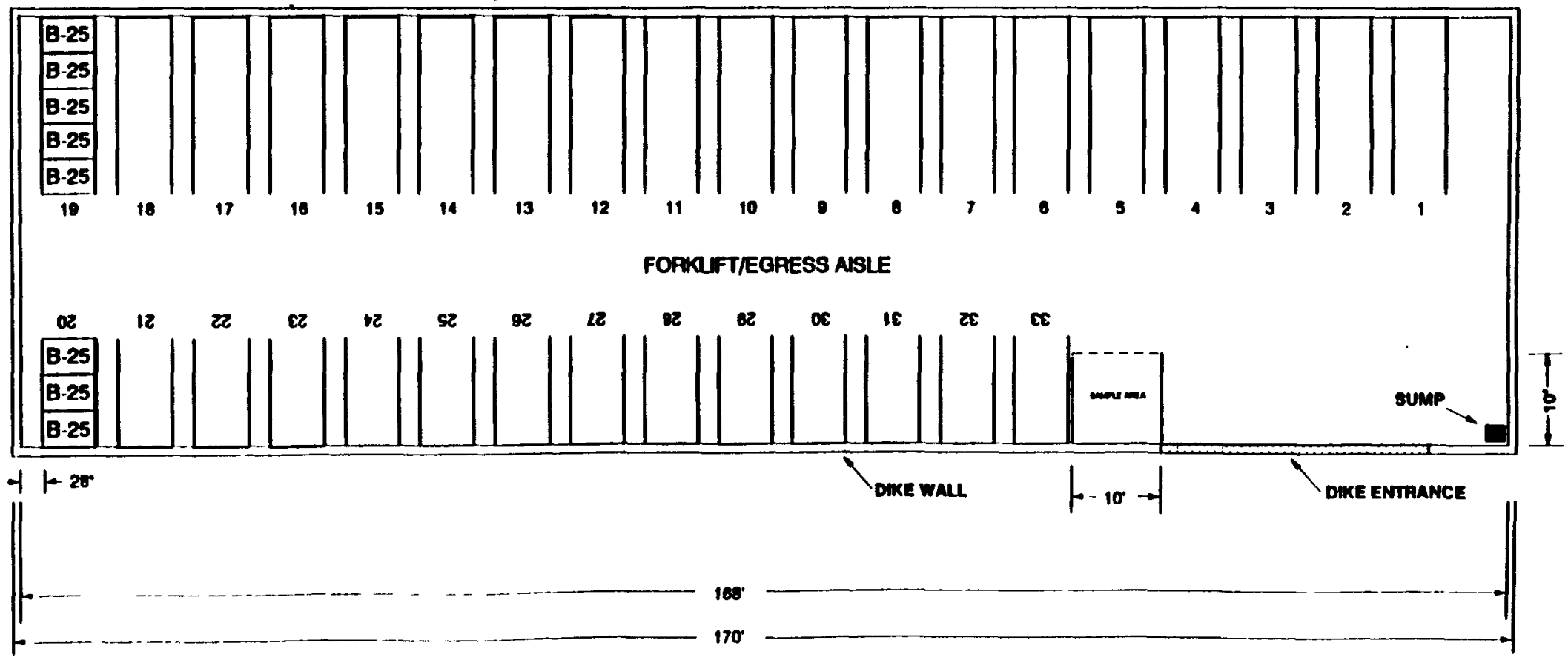


TABLE F-1. GENERAL INSPECTION SCHEDULE

Specific Item

Fire alarm system

Telephone system

Public address (PA) system

Generators

Facility fence

Gates

Two-way radios

Standard industrial absorbents

Absorbal, diaper wipes

Portable pump

Breathing Equipment:

disposable respirators, cartridges

Protective Clothing: Tyvek suits, gloves, and booties

Fire extinguishers

Emergency shower and eyewash

Face shields and extra protective eye glasses

Loading and unloading areas
Types of Problems

Power failure

Power failure, cut lines

Power failure, speakers

Fuel supply, spark plugs, oil

Corrosion, damage to chainlink fence or barbed wire

Corrosion, damage

Transmitter or receiver, batteries

Out of stock

Out of stock

Clogging

Out of stock, exhausted

canisters, leaks, tears, rips

Out of stock, holes, rips, tears

Missing, recharge needed, wrong type

Water pressure, leaking, and drainage

Broken, dirty equipment, out of stock

Spills and leaks
Frequency of Inspection

Annually

As used

Daily

As used

Daily

Daily

As used

Weekly

Weekly

Weekly

Weekly

Weekly

Weekly

Weekly

Weekly

As used 


\section{TABLE F-2. CONTAINER STORAGE AREA INSPECTION SCHEDULE}

Specific Item

Container placement and stacking

Sealing of containers

Labeling of containers

Container structural integrity

Segregation of incompatible wastes

Pallets

Building integrity

Bases or foundations

Dikes and/or curbing

Sump areas

Debris and refuse

Ramps

Fence and warning signs

Pumps
Types of Problems

Aisle space, height of stacks

Open lids

Improper identification, date missing

Corrosion, leakage, structural defects

Storage of incompatible wastes in same area

Damage (e.g., broken wood, warping, nails missing)

Damage, sagging, leaking

Cracks, deterioration, spalling in concrete, wet spots

Cracks, deterioration, leakage

Erosion, uneven settlement, cracks and spalling in concrete, wet spots, accumulated precipitation

Aesthetic, possible reaction with leaks

Erosion, uneven settlement, cracks, and spalling in concrete

Damaged or missing equipment, perimeter fence damaged, illegible signs

Leaks at pump seal
Frequency of Inspection

Weekly

Weekly

Weekly

Weekly

Weekly

Weekly

Weekly

Weekly

Weekly

Weekly

Weekly

Weekly

Weekly

Weekly 
TABLE F-3. DAILY INSPECTION LOG SHEET FOR CONTAINER STORAGE AREAS

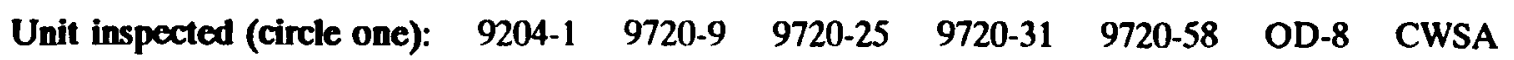

\begin{tabular}{|l|l|l|l|}
\hline \multicolumn{1}{|c|}{ General Inspection Items } & \multicolumn{1}{|c|}{ Types of Problems } & \multicolumn{1}{|c|}{$\begin{array}{c}\mathbf{X}=\text { Acoeptable } \\
\text { NA Unacceptable Not Applicable }\end{array}$} & $\begin{array}{c}\text { Observations, } \\
\text { Date and Nature of Repairs, Remedial } \\
\text { Action }\end{array}$ \\
\hline Telephone system (as used) & Power failure, cut lines & \\
\hline Public address (PA) system & Power failure, speakers & \\
\hline Generators (as used) & Fuel supply, spark plugs, oil & & \\
\hline Two-way radios (as used) & Transmitter or receiver, batteries & & \\
\hline Loading and unloading areas (as used) & Free from spills and leaks & & \\
\hline Additional Comments: & & & \\
\hline & & & \\
\hline
\end{tabular}


TABLE F-4. WEEKLY INSPECTION LOG SHEET FOR CONTAINER STORAGE ÁREAS

$\begin{array}{llllllll}\text { Unit inspected (circle one): } & 9204-1 & 9720-9 & 9720-25 & 9720-31 & 9720-58 & \text { OD-8 } & \text { CWSA }\end{array}$

\begin{tabular}{|c|c|c|c|}
\hline General Inspection ltems & Types of Problems & $\begin{array}{c}\checkmark=\text { Acceptable } \\
\mathbf{X}=\text { Unacceptable } \\
\text { NA }=\text { Not Applicable }\end{array}$ & $\begin{array}{c}\text { Observations, Date and Nature of Repairs } \\
\text { Remedial Action }\end{array}$ \\
\hline Standard industrial absorbent & Out of stock & & \\
\hline Absorbal, diaper wipes & Out of stock & & \\
\hline Portable pump & Clogging & & \\
\hline $\begin{array}{l}\text { Breathing equipment: disposable respirators, } \\
\text { cartridges }\end{array}$ & $\begin{array}{l}\text { Out of stock, exhausted canisters, leaks, } \\
\text { tears, rips }\end{array}$ & & \\
\hline Protective clothing: Tyvek suits, gloves, booties & $\begin{array}{l}\text { Out of stock, inoperative, holes, rips, } \\
\text { tears }\end{array}$ & & \\
\hline Fire extinguishers & Missing, recharge needed, wrong type & & \\
\hline Emergency shower, eyewash & Water pressure, leaking, drainage & & \\
\hline Face shields, protective eye glasses & Broken, dirty equipment, out of stock & & \\
\hline Container Inspection Items & Types of Problems & $\begin{array}{c}\checkmark=\text { Acceptable } \\
X=\text { Unacoeptable } \\
\text { NA }=\text { Not Applicable }\end{array}$ & $\begin{array}{l}\text { Observations, Date and Nature of Repairs } \\
\text { Remedial Action }\end{array}$ \\
\hline Container placement and stacking & Aisle space, height of stacks & & \\
\hline Closed containers & Open containers & & \\
\hline Labeling of containers & $\begin{array}{l}\text { Improper identification, storage or } \\
\text { accumulation start date missing }\end{array}$ & & \\
\hline Container integrity & Corrosion, leakage, structural defects & & \\
\hline Segregation of incompatible waste & $\begin{array}{l}\text { Incompatibles not segregated, reactives } \\
\text { not separated from ignition sources }\end{array}$ & & \\
\hline
\end{tabular}




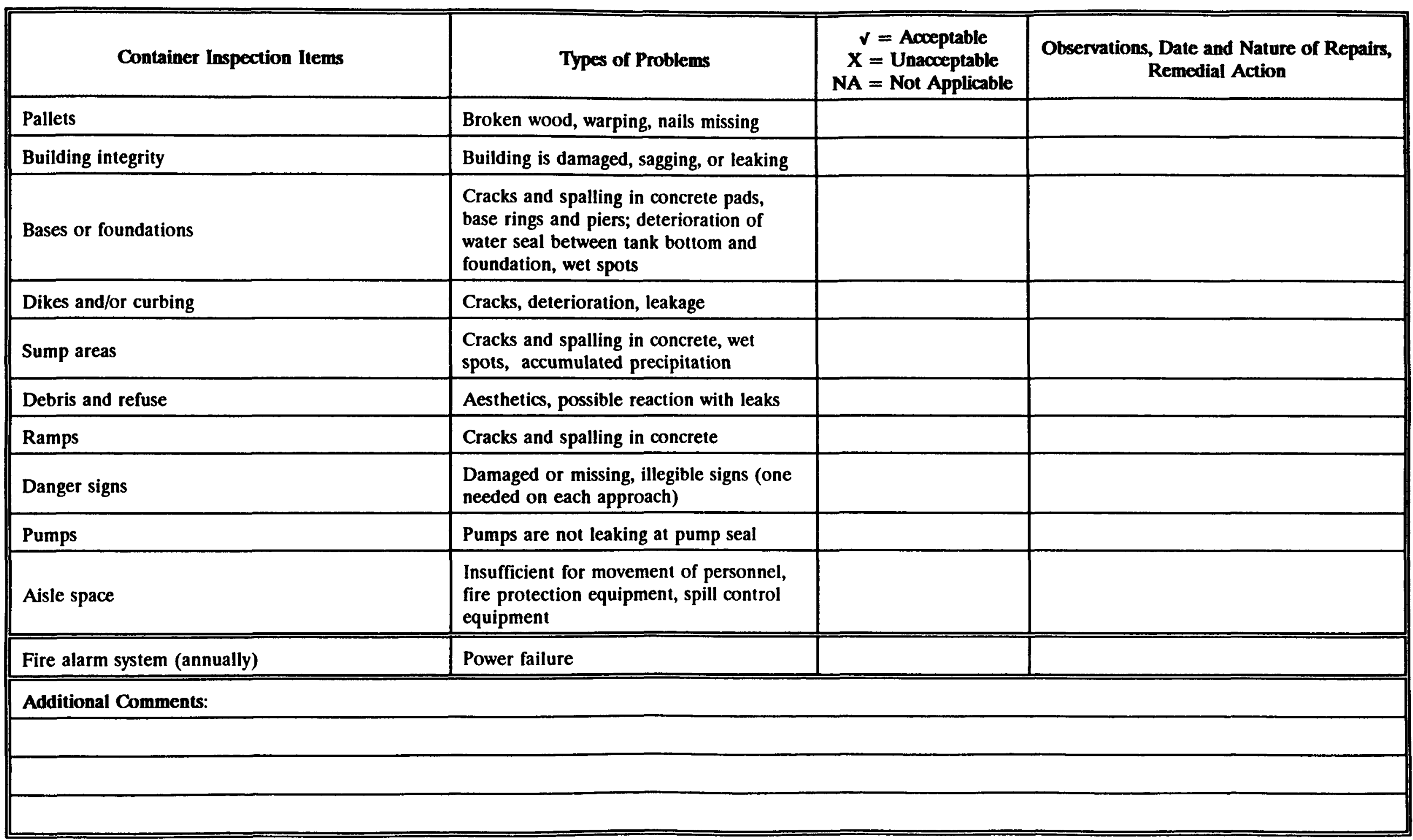




\section{APPENDIX H-2}

\section{FACILITY SUPERVISOR JOB DESCRIPTION (For Environmental Activities Only)}

\section{Position Title: Facility Supervisor, Waste Management Division}

Basic Function of Position: Provide technical support for waste management operations.

Major Environmental Duties and Responsibilities:

- Supervises technicians and operators in all aspects of operation of the facility, including loading, unloading, sampling, storage, inspections, maintenance, and emergency response.

- Reviews the training program for facility operating personnel.

- Inspects RCRA waste treatment and storage tank areas, tanks, dikes, transfer areas, piping, pumps, valves, and waste handling equipment.

- Inspects emergency response equipment including fire extinguishers, communications and alarm facilities, and spill cleanup equipment.

- Initiates appropriate remedial actions for spills, leaks, or defective equipment and ensures timely completion of remedial actions.

- Responsible for the recording of all inspections, remedial actions and their completion and maintains a file of all inspections, logs, and records.

- Works with technicians to identify, sample, and pack drums.

- Schedules all facility maintenance and oversees maintenance activities to ensure that proper procedures and safety precautions are followed, and no spill, fire, other release, or contamination of the facility, personnel, or the environment occurs.

\section{Formal Education Required:}

- High School diploma and/or equivalent education and/or experience.

Specialized Knowledge or Training:

- 24-hour OSHA/SARA Training -- one time only

- RCRA Annual Training

- Criticality Safety - given initially -- refresher is provided biennially

- Hazard Communication

- Radiation Protection - biennial

- Urinalysis - one time only

- Fire Protection - annual

- Health and Safety - annual

- Security Program - annual

- Emergency Preparedness - annual

- Respiratory Training - annual

- Ingress/Egress - the initial program is one time only - performance documentation checklists will be provided biennially

- General Employee Training - biennial 


\section{APPENDIX H-2 (Continued)}

\section{TECHNICIAN JOB DESCRIPTION}

(For Environmental Activities Only)

Position Title: Technician, Waste Management Division

Basic Function of Position: Provides routine technically related operational support for Waste Management Operations.

Major Environmental Duties and Responsibilities:

- Inspects the containers and containment system for leaks or deterioration caused by corrosion or other factors, and material handling equipment.

- Inspects emergency response equipment including fire extinguishers, communications and alarm equipment, and spill cleanup equipment.

- Records inspection activity on inspection log and maintains a file of logs and records.

- Notifies Facility Supervisor of observed problems at the facility, emergency situations, and the need for contingency and/or remedial action.

- Verifies waste stream identification and documentation.

- Assures proper handling and storage of wastes, including separation of incompatible wastes, prevention of their contact or mixing, and separate storage of ignitables and reactives.

- Assures proper documentation of waste stream identification and storage location, inventory, inflow and outflow.

- Assists in immediate response to spills and notifies the PSS office and Staff Engineer.

Formal Education Required:

- High School diploma and/or equivalent education and/or experience.

Specialized Knowledge or Training:

- 24-hour OSHA/SARA Training -- one time only

- RCRA Annual Training

- Criticality Safety - given initially -- refresher is provided biennially

- Hazard Communication - one time only

- Radiation Protection - biennial

- Urinalysis - one time only

- Fire Protection - annual

- Health and Safety - annual

- Security Program - annual

- Emergency Preparedness - annual

- Respiratory Training - annual

- Ingress/Egress - the initial program is one time only -- performance documentation checklists will be provided biennially

- General Employee Training - biennial 


\section{APPENDIX H-2 (Continued) \\ HOURLY WORKER JOB DESCRIPTION \\ (For Environmental Activities Only)}

Position Title: Hourly Worker, Waste Management Division

Basic Function of Position: Under direct supervision, performs daily operational activities at Waste Management Facilities including the transferring of wastes and handling of waste containers.

Major Environmental Duties and Responsibilities:

- Assists with operations involving hazardous waste treatment and storage.

- Moves full and empty containers as required.

- Assists in emergency spill response and cleanup and fire control, and takes other emergency action in accordance with established procedures.

- Performs duties under the direction of the technician present.

Formal Education Required:

- High School diploma and/or equivalent education and/or experience

Specialized Knowledge or Training:

- Requires completion of waste management training program. Additionally, requires individuals to be designated respirator wearers.

- 24-hour OSHA/SARA Training -- one time only

- RCRA Annual Training

- Criticality Safety - given initially -- refresher is provided biennially

- Hazard Communication - one time only

- Radiation Protection - biennial

- Urinalysis - one time only

- Fire Protection - annual

- Health and Safety - annual

- Security Program - annual

- Emergency Preparedness - annual

- Respiratory Training - annual

- Ingress/Egress - the initial program is one time only -- performance documentation checklists will be provided biennially

- General Employee Training - biennial 


\section{APPENDIX H-2 (Continued) \\ CHEMICAL OPERATOR JOB DESCRIPTION \\ (For Environmental Activities Only)}

Position Title: Chemical Operator, Waste Management Division

Basic Function of Position: Follows established methods and techniques in performing a single or sequence of operations required in various waste treatment processes associated with the chemical and physical change of materials. Adjusts, regulates, controls, and operates a wide variety of standard and specialized waste treatment processes and associated equipment. Uses various measuring and recording equipment and devices. Maintains detail records of process parameters.

Major Environmental Duties and Responsibilities:

- Moves full and empty containers as required.

- Performs duties under the direction of the Waste Management Supervisor present.

- Must be able to perform basic arithmetic calculations including fractions and decimals.

- Performs single or sequence of operations required to transfer and/or treat various wastes.

- Monitors controls and processes to assure proper operation, transfer, and/or treatment.

- Maintains necessary operating records.

- Takes sample of waste streams from containers as required for analysis.

Formal Education Required:

- High School diploma and/or equivalent education and/or experience

Specialized Knowledge or Training:

- Must have a basic understanding of chemical processes. Additionally, requires individuals to be designated respirator wearers.

- 24-hour OSHA/SARA Training -- one time only

- RCRA Annual Training

- Criticality Safety - given initially - refresher is provided biennially

- Hazard Communication - one time only

- Radiation Protection - biennial

- Urinalysis - one time only

- Fire Protection - annual

- Health and Safety - annual

- Security Program - annual

- Emergency Preparedness - annual

- Respiratory Training - annual

- Ingress/Egress - the initial program is one time only -- performance documentation checklists will be provided biennially

- General Employee Training - biennial 


\section{APPENDIX H-2 (Continued) \\ TRAINING MANAGER JOB DESCRIPTION \\ (For Environmental Activities Only)}

Position Title: Training Manager, Waste Management Division

Basic Function of Position: Manage the divisional training program and assure that the required training for compliance with RCRA is developed, implemented, and documented.

Major Environmental Duties and Responsibilities:

- Organized and direct the function of training in a cost-effective manner to assure compliance with the training requirements of RCRA.

- Supervise any of the training positions reporting to the training manager. These positions may include training supervisors, instructional technologists, curriculum developers, training coordinators, training administrators, training instructors, on-thejob trainers, and/or subject matter experts.

- Analyze resource needs and create section training budget based on all requirements including RCRA.

- Develop long-range training plans for qualification of personnel in assigned section.

- Interface with management, DOE, and other agencies to determine training requirements including RCRA.

- Ensure all training meets DOE and Y-12 standards as well as RCRA requirements including assuring that the required annual RCRA training is performed and documented.

- Develop long-range training plans for training staff to assure compliance with RCRA.

- As applicable to RCRA compliance, oversee training contracts to ensure deliverables meet DOE and Y-12 standards of training.

Formal Education Required:

- Bachelors degree with formal training in adult learning, training analysis, design, development, implementation, evaluation, or equivalent work experience in a training function which demonstrates skills and knowledge have been acquired and utilized effectively.

Specialized Knowledge or Training:

- Successful completion of the DOE Basic Instructor course (Train-the-Trainer)

- Successful completion of Radiation Protection Instructor's course

- Successful completion of the Supervisor's On-The-Job Training course.

- 24-hour OSHA/SARA Training -- one time only

- Fire Protection - annual

- General Employee Training - biennial

- Security Program - annual

- Emergency Preparedness - annual 


\section{APPENDIX H-2 (Continued) \\ TRAINING ADMINISTRATOR JOB DESCRIPTION \\ (For Environmental Activities Only)}

Position Title: Training Administrator, Y-12 Technical Training Division(Specific Administrator assigned to support Waste Management Division)

Basic Function of Position: Provide assigned division with plant oversight technical training support to assure that all training requirements are met based on RCRA.

Major Environmental Duties and Responsibilities:

- Work with other training organizations to ensure that training programs meet DOE and Y-12 standards as well as comply with the RCRA training requirements. Provide written approval of acceptable programs.

- Work with other training organizations to develop long-range training plans for qualification of personnel in assigned section including annual RCRA training for the appropriate personnel.

- Interface with management, DOE, and other agencies to determine training requirements including RCRA.

- Work with other training organizations to develop long-range training plans for training staff.

- Develop training standards which will enhance the quality of training at Y-12 including performing periodic audits to assure compliance.

- Complete any other assignments assigned by their training manager in order to assure compliance with RCRA.

Formal Education Required:

- Bachelors degree with formal training in training analysis, design, development, implementation, evaluation, or equivalent work experience in a training function which demonstrates these skills and knowledge have been acquired and utilized effectively.

- In lieu of a BS/BA degree, three years of progressively expanding responsibilities in training related work.

Specialized Knowledge or Training:

- Successful completion of the DOE Basic Instructor course (Train-the-Trainer).

- Fire Protection - annual

- Security Program - annual

- Emergency Preparedness - annual

- General Employee Training - biennial 


\section{APPENDIX H-2 (Continued) \\ TRAINING COORDINATOR JOB DESCRIPTION \\ (For Environmental Activities Only)}

Position Title: Training Coordinator, Waste Management Division

Basic Function of Position: Develop, facilitate, and implement training activities for the personnel in assigned section of the Waste Management Division.

Major Environmental Duties and Responsibilities:

- In areas of subject matter experience, specifically RCRA, develop training courses using the Instructional System Development design.

- Using developed RCRA course material, instruct personnel in job required curriculum at least annually.

- Evaluate students for successful completion of RCRA training.

- In areas of subject matter experience, specifically RCRA, assist other instructors as required by the training manager in the development and delivery of course material.

- Establish and maintain all documentation of appropriate training files.

- Complete any other assignments assigned by their training manager.

Formal Education Required:

- High school diploma or equivalent.

Specialized Knowledge or Training:

- Successful completion of the DOE Basic Instructor course (Train-the-Trainer).

- Fire Protection - annual

- Security Program - annual

- Emergency Preparedness - annual

- General Employee Training - biennial 


\section{APPENDIX H-2 (Continued) \\ ON-THE-JOB TRAINER JOB DESCRIPTION \\ (For Environmental Activities Only)}

Position Title: On-The-Job Trainer, Waste Management Division

Basic Function of Position: Assist in the development of on-the-job training (OJT) courses, instruct personnel, evaluate trained personnel, and evaluate training.

Major Environmental Duties and Responsibilities:

- In areas of subject matter experience, specifically RCRA compliance and hazardous waste management, assist in the development of OJT courses.

- Using developed OJT course material, instruct personnel in job required curriculum for RCRA compliance and proper hazardous waste management.

- Evaluate RCRA training to ensure quality of program.

- Complete any other training assignments assigned by training manager.

Formal Education Required:

- High school diploma or equivalent.

Specialized Knowledge or Training:

- Successful completion of the Supervisor's On-The-Job Training course.

- 24-hour OSHA/SARA Training -- one time only

- RCRA Annual Training

- Criticality Safety - given initially -- refresher is provided biennially

- Hazard Communication - one time only

- Radiation Protection - biennial

- Urinalysis - one time only

- Fire Protection - annual

- Health and Safety - annual

- Security Program - annual

- Emergency Preparedness - annual

- Respiratory Training - annual

- Ingress/Egress - the initial program is one time only -- performance documentation checklists will be provided biennially

- General Employee Training - biennial 